\title{
GoRJugaLdePERTO
}

\section{As Festas \\ do Espírito Santo nos Açores}

Um Estudo de Antropologia Social

João Leal

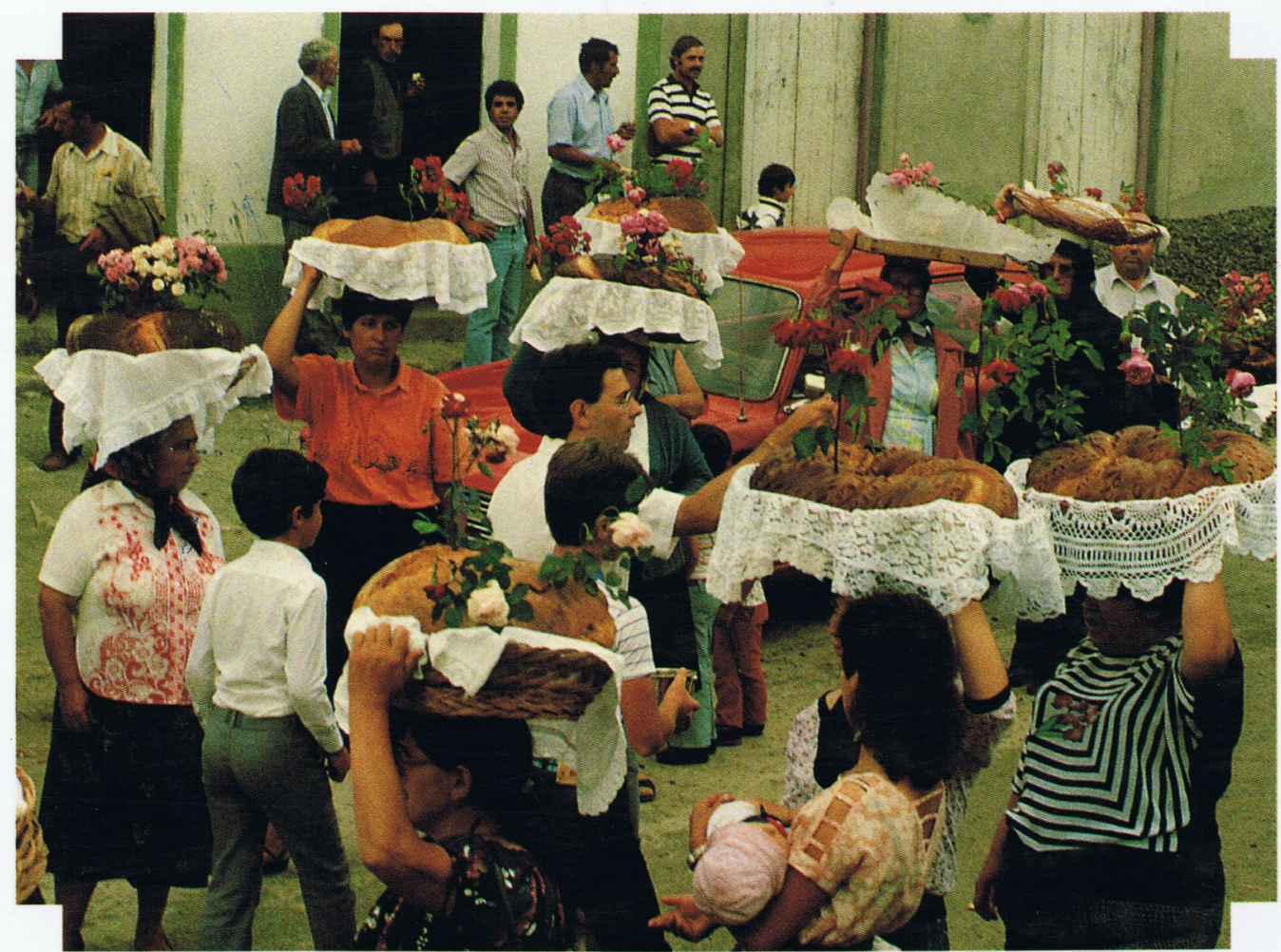

TPUBGCAÇÕESФOMQUIXOTE 


\section{PORTUGAL DE PERTO}

Biblioteca de Etnografia e Antropologia

dirigida por

Joaquim Pais de Brito

do ISCTE

Dois critérios presidem à escolha dos títulos desta colecção, critérios esses já sugeridos no próprio nome que a encabeça - Portugal de Perto. Em primeiro lugar, todos eles se reportam ao espaço português, estudando os mais diversos aspectos da sua cultura (poderíamos dizer: das suas culturas). Em segundo lugar, esse estudo é feito mais ou menos de perto, com base num trabalho de recolha directa, e propõe-se, algumas das vezes, trazer para mais perto fatias do real descuradas ou desconhecidas. Tudo isso nos limites de uma área disciplinar que, grosso modo, vai da Etnografia à Antropologia, e dirigindo-se não só aos estudiosos e especialistas, como também à curiosidade do grande público. 
AS FESTAS DO ESPÍRITO SANTO NOS AÇORES 


\section{O AUTOR:}

João Leal nasceu em 1954, em Lisboa. É licenciado em Antropologia pelo I.S.C.S.P. e, em 1992, doutorou-se em Antropologia Social pelo I.S.C.T.E., com uma tese intitulada "Cerimonial, Relações Sociais e Tempo. As Festas do Espírito Santo nos Açores». E professor de Antropologia Social no I.S.C.T.E. e investigador e membro da direcção do Centro de Estudos de Antropologia Social (C.E.A.S.) do mesmo Instituto. Autor de diferentes artigos que, além das Festas do Espírito Santo nos Açores, cobrem também a história da Antropologia em Portugal.

Organizou e prefaciou, para esta mesma colecção, os seguintes volumes:

Contribuições para Uma Mitologia Popular Portuguesa e Outros Escritos Etnográficos, Consiglieri Pedroso; Contos Tradicionais do Povo Português, Teófilo Braga; Obra Etnográfica ( $1^{\circ}$ Vol.) Festas, Costumes e Outros Materiais para Uma Etnologia de Portugal, Adolfo Coelho; Obra Etnográfica (2. ${ }^{\circ}$ Vol.); Cultura Popular e Educação, Adolfo Coelho. 
JOÃO LEAL

\title{
AS FESTAS DO ESPÍRITO SANTO NOS AÇORES
}

\author{
Um Estudo de Antropologia Social
}

PUBLICAÇÕES DOM QUIXOTE

LISBOA

1994 
Biblioteca Nacional - Catalogação na Publicação

Leal, João, 1954-

As festas do Espírito Santo nos Açores:

Um estudo de antropologia social

(Portugal de perto; 29)

ISBN 972-20-1166-9

CDU 394.2 (469.9)

Publicações Dom Quixote, Lda.

Rua Luciano Cordeiro, 116-2. ${ }^{\circ}$

1098 Lisboa Codex - Portugal

Reservados todos os direitos

de acordo com a legislação em vigor

(C) João F. Leal, 1994

Foto da Capa de: João F. Leal

1. ${ }^{\text {a }}$ edição: Maio de 1994

Depósito legal n. 76 690/94

Fotocomposição: Textype - Artes Gráficas, Lda.

Impressão e acabamento: Tilgráfica, S.A.

ISBN: 972-20-1166-9 


\section{ÍNDICE}

PARTE I. OS IMPÉRIOS NA FREGUESIA DE SANTA BÁRBARA

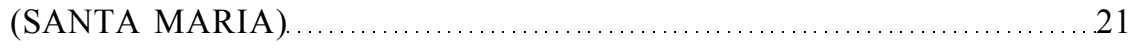

1. A Freguesia: Aspectos Gerais ........................................23

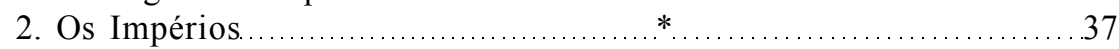

3. A Parte dos Deuses ..................................................... 65

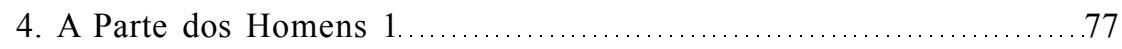

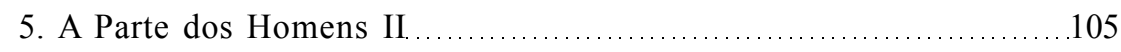

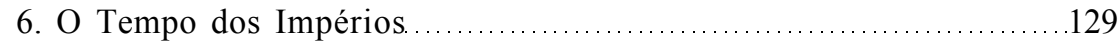

7. Os Dois Imperadores .....................................................

PARTE II. DIVERSIDADE E UNIDADE DAS FESTAS DO ESPÍRITO

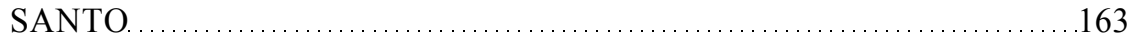

8. Outras Ilhas, Outras Festas..............................................165

9. Jantares, Gastos e Festas: Santo Antão (São Jorge) ................... 191

10. Coroações e Impérios: Piedade (Pico) ..................................221

PARTE III. SÃO MIGUEL: ROMARIAS QUARESMAIS E FESTAS DO

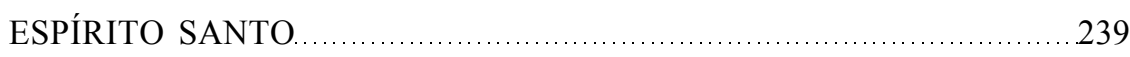

CONCLUSÕES

APÊNDICE A. Festas do Espírito Santo, Povo e Clero ..........................2269

APÊNDICE B. As Festas do Espírito Santo no Continente e na Madeira.. 283 
AS FESTAS DO ESPÍRITO SANTOS NOS AÇORES

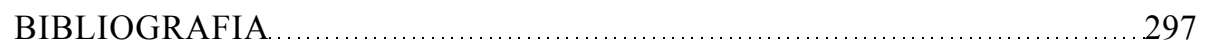

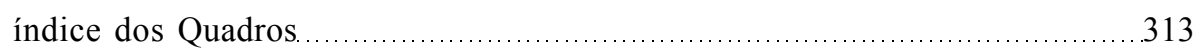

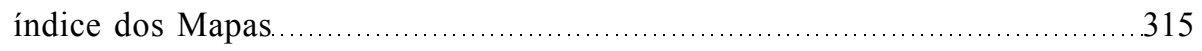

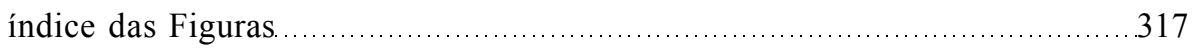

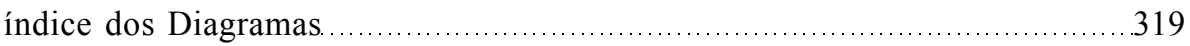




\section{AGRADECIMENTOS}

O presente volume - inicialmente apresentado, numa forma algo diferente da actual, como Tese de Doutoramento em Antropologia Social no I.S.C.T.E. - resulta de uma pesquisa cujo início remonta a 1982, ano em que realizei a minha primeira deslocação aos Açores. Desde essa altura até à actualidade contraí um enorme «rol» de dívidas - em relação tanto a instituições como a pessoas - que espero que este livro contribua para "saldar».

Entre as instituições merecem relevo particular a Fundação Calouste Gulbenkian - que me concedeu um subsídio quando da minha segunda deslocação, em 1983, a Santa Bárbara - e, sobretudo, o I.N.I.C., que me atribuiu, entre 1987 e 1991, uma bolsa de estudo para doutoramento. O I.S.C.T.E. forneceu-me também, em várias ocasiões, financiamentos para viagens que foram de grande utilidade. Finalmente, a John Rylands Library da Universidade de Manchester proporcionou-me, por diversas vezes, condições de trabalho que facilitaram muito o meu trabalho de pesquisa bibliográfica.

Mas a minha dívida de gratidão é sobretudo para com as muitas pessoas cuja amizade e auxílio foram determinantes para a realização deste estudo.

Entre essas pessoas estão, em primeiro lugar, os meus pais. A configuração inicial desta pesquisa deve muito à sua «experiência açoriana»e aos seus contactos no arquipélago.

Em Santa Bárbara, a minha dívida estende-se, para além dos vários imperadores a cujos Impérios assisti, às Sr. ${ }^{\text {as }}$ Angelina Benta, Ana de Fontes, Inês da Maia, Angelina da Cruz e aos Srs. Manuel Bento, prof. Jaime de Figueiredo, Mestre Resendes, José de Sousa Bairos, José dos Santos, António de Sousa, António Fontes e António Catarina. O Dr. Jacinto Monteiro, o Sr. José de Sousa e o P. José Maria Amaral foram também de um inestimável auxílio em vários passos do meu trabalho. Agradeço ainda à Câmara Municipal e à Repartição de Finanças de Vila do Porto as facilidades concedidas para a consulta dos seus arquivos. Em Santo Antão, gostava de agradecer em particular aos vários mordomos das Festas do Espírito Santo e ainda ao Sr. Manuel Inácio 
e à Sr. ${ }^{\text {a }}$ Carmina, ao Dr. Alberto Bettencourt e ao Sr. Luís Marques. Na Piedade, além mais uma vez dos mordomos das Festas, agradeço também o auxílio e amizade do Sr. António José de Freitas e família e do P. ${ }^{\text {e }}$ Manuel António das Matas. Em São Miguel, estou particularmente grato ao mestre João Manuel de Sousa, do rancho de Ponta Garça. O Sr. João Vieira, nas Flores, e a Helena Ormonde, na Terceira, prestaram-me também uma ajuda importante nos «raids» etnográficos que efectuei nessas duas ilhas. O Rui Sousa Martins, da Universidade dos Açores, além de um apoio logístico imprescindível, foi sempre um interlocutor atento e estimulante nas muitas conversas que tivémos. Finalmente, os Serviços Geográficos e Cadastrais dos Açores, os Serviços Regionais de Estatística dos Açores - na pessoa do Eng. André de Oliveira -

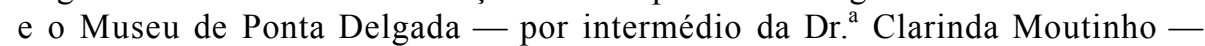
facultaram-me o acesso a elementos de grande utilidade para o meu trabalho.

No decurso do processo de elaboração deste livro recebi de vários colegas e amigos manifestações de interesse e apoio que foram de grande importância. Entre essas pessoas, gostaria em particular de expressar a minha gratidão ao Prof. Dr. José Carlos Gomes da Silva, que assegurou a orientação da minha pesquisa e com quem mantive um diálogo produtivo - feito de inúmeras sugestões e críticas — que enriqueceu substancialmente a minha reflexão. A Rosa Maria Perez, o Benjamim Pereira, o Joaquim Pais de Brito, director desta Colecção, o Paulo Valverde, o Francisco Vaz da Silva e a Maria Morais tiveram pelo seu lado a paciência de ler e comentar versões prévias de parte ou da totalidade dos capítulos que integram este livro, tendo fornecido importantes sugestões e estímulo para o meu trabalho. É entretanto inútil sublinhar que a responsabilidade final do texto - em particular das suas insuficiências - me cabe exclusivamente a mim. O Joaquim Pais de Brito facultou-me ainda alguns elementos importantes para a elaboração do Apêndice sobre as Festas do Espírito Santo no Continente e na Madeira. Agradeço também as observações formuladas pela Prof. ${ }^{a}$ Dr. ${ }^{a}$ Alice Geraldes, na sua qualidade de arguente das minhas provas de doutoramento. Mas é sobretudo com a Rosa Maria Perez que a minha dívida é maior. Do Gujarat aos Açores vai certamente uma grande distância, mas a nossa já longa amizade, combinada com o facto de termos elaborado as nossas Teses ao mesmo tempo, estabeleceu entre nós uma proximidade - feita de cumplicidade e solidariedade — que, no que me respeita, foi decisiva em certos momentos mais difíceis da minha reflexão.

Dedico este estudo à Margarida, à Sofia e à Teresa. Em primeiro lugar porque, sem elas, não só este livro, como muitas outras coisas teriam muito menos sentido. Em segundo lugar, porque, a par de uma paciência grande em relação às minhas ausências açorianas, suportaram sempre com grande estoicismo as variações de humor, a ansiedade e tudo o mais que tende a aparecer associado ao processo de pensar e redigir um texto com estas características. Por estas e outras razões, este estudo - agora que «o urso saiu da jaula» pertence-lhes também. 
APRESENTAÇÃO 
Embora existam algumas referências a festividades com características similares noutros contextos - designadamente em França ${ }^{1}$ - as Festas do Espírito Santo constituem em grande medida um traço específico da cultura popular portuguesa.

A sua origem, de acordo com um conjunto de narrativas eclesiásticas seiscentistas, é geralmente situada no séc. XIV, em Alenquer, e atribuída à Rainha Santa Isabel. Entre essas narrativas, destacam-se as de D. Rodrigo da Cunha, na «História Eclesiástica da Igreja de Lisboa» (1642: 122), de Frei Manuel da Esperança, na «História Seráfica da Ordem dos Frades Menores de S. Francisco na Província de Portugal» (1656: 131 e 132), de Frei Francisco Brandão, na «Monarquia Lusitana» (1672: 185) e do P. Manoel Fernandes (1690: 914). A partir destas fontes, o historiador Jaime Cortesão, sem pôr em causa a importância da Rainha Santa Isabel no impulso inicial dado ao culto, defendeu a sua ligação à acção dos franciscanos espirituais e à ideologia milenarista do Abade calabrês Joaquim de Fiore, construída em torno da próxima chegada de uma Idade do Espírito Santo (cf. Cortesão, 1980: 256 a 270). Tendo conhecido no continente uma difusão bastante ampla - particularmente no centro e sul do país - as Festas do Espírito Santo irradiaram ainda, a partir do continente, para territórios povoados e colonizados pelos portugueses. A sua existência é conhecida na Madeira e no Brasil. Mas foi sobretudo no arquipélago dos Açores - onde a sua origem parece remontar aos tempos iniciais do povoamento ${ }^{2}$ que elas conheceram um desenvolvimento mais importante. E é lá, num quadro genericamente caracterizado hoje em dia - tanto no continente como na

${ }^{1}$ Cf. a este respeito, Duparc, 1958, e Van Gennep, 1949, 1652-1661 e 1723-1724.

${ }^{2}$ Entre os testemunhos relativos ao desenvolvimento inicial das Festas do Espírito Santo nos Açores, refiram-se as menções incluídas nas Saudades da Terra — crónica quinhentista açoriana da autoria de Gaspar Frutuoso - relativas às ilhas de Santa Maria (Frutuoso, 1971: 106-107), São Miguel (id., 1977: 281; 1981: 240-241) e Flores (id., 1978: 351). 
Madeira - pelo seu declínio e quase desaparecimento, que as Festas do Espírito Santo guardam intacta a sua relevância. Atestada pela sua presença exaustiva em todas as freguesias do arquipélago, esta vitalidade das Festas do Espírito Santo expressa-se ainda no modo como, a partir dos Açores, elas se difundiram nos principais contextos de acolhimento da emigração açoriana: o Brasil, no passado, e os E.U.A. e o Canadá, mais recentemente ${ }^{1}$.

\section{II}

Tendo alimentado, desde finais do século XIX, uma bibliografia etnográfica numerosa, as Festas do Espírito Santo têm sido sobretudo interpretadas no quadro de um conjunto de discursos de natureza ideológica que procuram enraizar a «identidade nacional» num projecto de matriz milenarista de que o culto do Espírito Santo seria a expressão mais emblemática. Estreitamente ligada à chamada «filosofia portuguesa», esta leitura das Festas do Espírito Santo - particularmente clara nas obras de autores como Agostinho da Silva (1985), António Quadros (1987) ou Breda Simões (1986 e 1987) — beneficiou, nos anos 80, de uma certa condescendência mediática e universitária, inseparável do modo como certos círculos intelectuais olham a «cultura popular»: um domínio que, mais do que uma racionalidade intrínseca, possuiria sobretudo uma série de virtualidades, largamente imaginárias, para a discussão de questões relacionados com essa recorrente obsessão da cultura portuguesa pela «identidade nacional» ${ }^{2}$.

São obviamente outras as intenções deste estudo. Nele, partindo desse contexto privilegiado que são os Açores, procura-se interrogar as Festas do Espírito Santo a partir das aquisições metodológicas e teóricas que caracterizam o campo disciplinar da Antropologia Social.

Resultando de um trabalho de terreno conduzido intermitentemente entre 1982 e 1989 e que no total se estendeu por cerca de dois anos, «As Festas do Espírito Santo nos Açores. Um Estudo de Antropologia Social» tem como principal objectivo propor um conjunto de linhas de interpretação do ritual contextualizadas por referência a registos como as formas de religiosidade, a estrutura das relações sociais e as formas de conceptualização cíclica do tempo nas sociedades rurais.

\footnotetext{
${ }^{1}$ Acerca das Festas do Espírito Santo nas comunidades açorianas emigradas, cf., entre outros, Gayton, 1948 e 1959 e Salvador, 1981.

${ }^{2}$ Tive ocasião de proceder a uma análise deste tipo de aproximações às Festas do Espírito Santo em Leal, 1992. Nessa comunicação, chamo também a atenção para as utilizações ideológicas das Festas do Espírito Santo como meio de produção de «identidade regional» no quadro dos Açores.
} 
No tratamento dado a estas questões, procurei articular a «espessura histórica» inscrita nas composições rituais que observei e nas palavras e gestos que as dotam de sentido com os inúmeros sinais de mudança e contemporaneidade que elas transmitem. Como se tornará claro no decurso do texto, as Festas do Espírito Santo formam um universo cuja significação se estrutura no ponto de intersecção dessas duas pulsões.

A I Parte do livro - subordinada ao título «Os Impérios em Santa Bárbara» - constrói-se em torno do estudo detalhado dos Impérios - designação por que são localmente conhecidas as Festas do Espírito Santo - na freguesia de Santa Bárbara (Santa Maria). Por motivos de natureza algo aleatória, foi nesta freguesia que conduzi uma recolha mais minuciosa e prolongada de informação e é fundamentalmente por essa razão - e não devido a quaisquer juízos sobre o carácter mais ou menos arquetípico das Festas do Espírito Santo nesta ou noutras freguesias — que ela fornece o «contexto de referência» para a abordagem das Festas do Espírito Santo que proponho.

Depois de uma caracterização inicial da freguesia, é feita uma apresentação desenvolvida da estrutura etnográfica das Festas. Os Capítulos seguintes centram-se na análise dos Impérios. Tomando como fio condutor o relevo que na sequência dos festejos tem um conjunto de dádivas e contra-dádivas de natureza alimentar, começo por pôr em destaque - em «A Parte dos Deuses» o significado religioso de que estas se revestem. Os dois Capítulos seguintes — «A Parte dos Homens I» e «A Parte dos Homens II» - exploram de forma detalhada a ligação existente entre esse conjunto de dádivas e contra-dádivas e a reiteração dos principais círculos de relacionamento social em Santa Bárbara: o parentesco e a vizinhança, em primeiro lugar, e o lugar e a freguesia, depois. É justamente a natureza exacta desse empreendimento sociológico que o Capítulo «O Tempo dos Impérios» se propõe examinar. Depois de sublinhar a dimensão sazonal dos festejos, chamo a atenção para a importância do contraste entre os Impérios e os «ciclos» do Carnaval e da Quaresma - que antecedem imediatamente o período tradicionalmente consagrado à realização dos festejos — na interpretação das suas características sociológicas. Estas são depois postas em relação com os ritmos e temporalidades que estruturam o calendário anual no seu conjunto. E nesse quadro, por fim, que são examinadas as novas formas que tende a assumir na freguesia o vínculo entre ritual, estrutura social e tempo. Culminando a primeira parte do percurso proposto, o Capítulo «Os Dois Imperadores» tenta proceder a uma caracterização mais exacta da figura do imperador - designação atribuída ao promotor dos festejos - com incidência particular nas «pulsões» de carácter individualista, ligadas a motivos de prestígio individual a que, por seu intermédio, os Impérios são submetidos.

Na II Parte e uma vez constatada a diversidade etnográfica que as Festas do Espírito Santo apresentam nas restantes ilhas dos Açores - Capítulo «Outras Ilhas, Outras Festas» - tenta-se verificar até que ponto e de que forma as principais linhas de análise construídas em torno dos Impérios de 


\section{AS FESTAS DO ESPÍRITOSANTOSNOS AÇORES}

Santa Bárbara são susceptíveis de generalização a outras modalidades de estruturação dos festejos. Com esse objectivo são sucessivamente passadas em revista as Festas do Espírito Santo nas freguesias de Santo Antão (São Jorge) - Capítulo 9 - e Nossa Senhora da Piedade (Pico) - Capítulo 10. A organização interna de ambos os Capítulos reproduz de forma abreviada o tipo de percurso seguido na I Parte, por forma a facilitar o balanço das diferenças e similitudes entre as várias modalidades de organização dos festejos.

Ocupando um lugar de relevo no modelo de interpretação das Festas do Espírito Santo proposto no decurso da I e da II Partes, o vínculo entre os festejos e as formas de conceptualização do tempo nas sociedades rurais fornece o ponto de partida para a III Parte. Tomando por base as Romarias Quaresmais de São Miguel, procura-se aprofundar alguns aspectos do contraste - inicialmente trabalhado em torno de Santa Bárbara - entre Festas do Espírito Santo e Quaresma tal como ele se apresenta na ilha de São Miguel.

Nas Conclusões, por fim, depois de uma chamada de atenção para algumas especificidades do contexto etnográfico açoriano, sugerem-se algumas linhas de discussão de alcance mais geral, designadamente em torno do relevo da linguagem da dádiva em contexto rural europeu e do vínculo entre ritual, tempo e estrutura social.

Finalmente, julguei útil acrescentar dois Apêndices. O primeiro, de perfil mais analítico, visa caracterizar o tipo de relação existente entre povo e clero em torno das Festas do Espírito Santo nos Açores. O segundo, de características fundamentalmente etnográficas, procura dar uma imagem da distribuição e principais características das Festas do Espírito Santo no Continente e na Madeira. Em conjunto com os elementos fornecidos acerca dos Açores, os dados aí reunidos possibilitarão ao leitor uma visão de conjunto das Festas do Espírito Santo em Portugal.

A Antropologia Social tem-se caracterizado, do ponto de vista metodológico, pela oscilação entre dois modelos de pesquisa que podemos designar como o «modelo monográfico» e o «modelo comparativo». Enquanto o primeiro enfatiza o estudo intensivo e prolongado de uma comunidade de dimensão reduzida, baseada na chamada observação participante, o segundo valoriza a produção, a partir de várias observações «monográficas» independentes, de confrontos e generalizações sobre conjuntos determinados de factos sociais e culturais.

Este estudo situa-se a meio caminho entre estes dois modelos. A Parte I reclama-se claramente do modelo monográfico, mas, gradualmente, ao longo das Partes II e III, há uma deslocação no sentido do modelo comparativo. 
As razões para este percurso prendem-se em larga medida com a «biografia» da própria pesquisa. Inicialmente, as minhas intenções eram as de realizar um estudo monográfico clássico em torno das Festas do Espírito Santo centrado num contexto preciso. Foi com esse objectivo que iniciei, em 1982, o meu trabalho de terreno em Santa Bárbara. A minha estada na freguesia foi então de dois meses. Em 1983, complementei essa primeira recolha de informação com uma estada mais prolongada, que se estendeu por 4 meses. Mas foi em 1987 que o grosso do trabalho de terreno foi realizado, numa estada que se prolongou de Julho desse ano até Fevereiro de 1988. No decurso desta pesquisa instalou-se gradualmente uma certa curiosidade em relação às modalidades de organização dos festejos noutras ilhas do arquipélago. Com esse objectivo viria a realizar, em várias ocasiões distintas, um conjunto de recolhas orais de informação num número representativo de freguesias de cada ilha, complementadas, em certos casos - Terceira, São Jorge, Pico, Flores - pela assistência ao ritual. Rapidamente, essa curiosidade ganhou uma dimensão menos etnográfica. A questão que se me colocava era a de saber até que ponto alguns dos grandes motivos estruturadores dos festejos tal como os tinha inicialmente detectado em Santa Bárbara se poderiam reencontrar por detrás dessas outras modalidades do ritual. Foi nessa perspectiva que realizei os dois estudos de caso em Santo Antão e na Piedade, baseados em trabalho de terreno que decorreu respectivamente entre Março e Agosto de 1988 e entre Abril e Maio de 1989. Foi também com esse objectivo que, em Fevereiro de 1988, acompanhei o Rancho de Ponta Garça na sua Romaria.

Marcado por este percurso metodológico algo híbrido, o presente estudo, como o leitor terá ocasião de verificar, propõe, de um ponto de vista teórico, numerosas linhas de diálogo com a literatura antropológica tanto clássica como recente. O peso da primeira - e, em particular de certos nomes, como Mauss ou Van Gennep - assenta na convicção de que a reflexão antropológica contemporânea, ao mesmo tempo que se baseia numa constante capacidade de abertura de novos horizontes interpretativos, continua a colocar-se um certo número de questões que, de forma directa ou indirecta, são tributárias das interrogações e propostas de análise avançadas nos anos em que ela se afirmou como um campo disciplinar autónomo.

Essa tendência «classicista» reflecte-se também num estilo de escrita que, por contraste com a «reflexividade» predominante nalguns textos antropológicos mais recentes, possui uma respiração mais clássica. Gostava de esclarecer, em primeiro lugar, que esse facto não traduz da minha parte uma relação distante com a realidade. Pelo contrário, por detrás deste texto há uma 
paixão muito grande pelas pessoas e pelas coisas. Os anos que passei nos Açores foram seguramente «dos melhores anos da minha vida». Em segundo lugar, gostava de sublinhar que esse estilo de escrita só por ilusão de óptica pode dar a impressão que confundo as minhas linhas de análise com certezas impessoais. Em Antropologia Social, as certezas, além de provisórias, são sempre pessoais. Este é o meu olhar, resultante da minha forma de me relacionar com as pessoas e do meu modo de ver as coisas. Noutras circunstâncias, outras pessoas produziriam outras certezas, resultantes de outros olhares, de outras formas de relacionamento com as pessoas e de outros modos de ver as coisas. 


\section{PARTE I}

OS IMPÉRIOS NA FREGUESIA DE SANTA BÁRBARA (SANTA MARIA) 


\section{CAPÍTULO 1}

A FREGUESIA: ASPECTOS GERAIS 
Constituído por nove ilhas, descobertas entre 1427 e 1452 por navegadores portugueses ao serviço da Coroa, o arquipélago dos Açores - apesar de um certa diversidade interna - apresenta, do ponto de vista geográfico, algumas grandes constantes. Entre elas destacam-se a sua origem vulcânica - acompanhada na maioria das ilhas pela ocorrência de fenómenos de vulcanismo activo (erupções vulcânicas, terramotos, etc...) - e um clima temperado marítimo caracterizado por variações térmicas anuais fracas, uma forte humidade e nebulosidade e valores de precipitação consideráveis. A humanização da paisagem assenta num regime agrário baseado na agricultura sem rega e na criação de gado vacum. De uma forma geral, a uma faixa litoral com uma ocupação predominantemente agrícola, sucede uma faixa de terrenos de pastagens, e, por fim, em altitudes superiores, um regime misto de pastagens e matas. A propriedade apresenta-se fortemente dividida e o povoamento nas áreas rurais oscila entre o disperso e o disperso-orientado. Em cada ilha, existem um ou mais centros urbanos, de importância variável de acordo com a própria dimensão da ilha, onde se concentram as funções administrativas e comerciais e por onde se processam os contactos com o exterior. A população total do arquipélago era em 1981 de 249.101 habitantes, desigualmente distribuídos pelas diferentes ilhas. Como se pode verificar no Quadro 1, a ilha de São Miguel, com 136.326 habitantes era a mais importante, seguida da Terceira, com 59.204 habitantes. Num grupo intermédio situam-se as ilhas de São Jorge, Pico e Faial com populações situadas entre os 10.000 e os 15.000 habitantes - e as ilhas de Santa Maria, Graciosa e Flores - com populações da ordem dos 4.000/ /6.000 habitantes. A ilha do Corvo, com os seus 375 habitantes, é a menos populosa do arquipélago.

O arquipélago tem conhecido um conjunto de transformações nos últimos 30/ 40 anos, ligadas sobretudo a dois factores principais: a emigração de uma parte importante da sua população, a partir dos anos 60, para os E.U.A. e 


\begin{tabular}{lr}
\hline \multicolumn{1}{c}{ ILHA } & POPULAÇ̃̃O \\
\hline Santa Maria & 6338 \\
São Miguel & 132326 \\
Terceira & 59204 \\
Graciosa & 5373 \\
São Jorge & 10255 \\
Pico & 15224 \\
Faial & 15563 \\
Flores & 4393 \\
Corvo & 375 \\
\hline
\end{tabular}

\section{QUADRO 1 \\ População dos Açores por ilha (1981) \\ \{Fonte: I.N.E., 1981)}

Canadá, e a implantação, a partir do final da década de 70 , da autonomia político-administrativa regional. A emigração - que se traduziu num decréscimo global da população do arquipélago, entre 1960 e 1981, de 78.378 habitantes - possibilitou um melhoramento geral das condições de vida, em particular nos meios rurais, devido tanto ao abrandamento da pressão demográfica sobre a terra, como ao afluxo de remessas dos emigrantes. Quanto à autonomia político-administrativa, ela permitiu designadamente o lançamento de numerosas infra-estruturas - estradas, aeroportos, portos que, além de consequências positivas sobre o nível de vida da população, contribuíram para atenuar o isolamento das ilhas entre si e em relação ao exterior.

Apesar destas transformações, a economia do arquipélago continua a ter uma importante base rural. Simultaneamente, apesar da influência combinada da emigração e da intensificação dos contactos com o exterior, mantem-se nos meios rurais uma cultura popular muito viva e fortemente individualizada. Se o retrato arcaizante dos Açores traçado no final dos anos 20 por Raul Brandão (1926) e Leite de Vasconcelos (1926) pertence em grande medida ao passado, não é menos certo que as principais expressões da cultura popular açoriana - entre as quais ocupam justamente um lugar central as Festas do Espírito Santo - se caracterizam por uma profundidade histórica muito marcada. Não se fechando à mudança, a cultura popular açoriana constitui ao mesmo tempo um lugar privilegiado de diálogo com aquilo a que os historiadores chamam a «longa duração» e os antropólogos preferem designar por «tradição». 


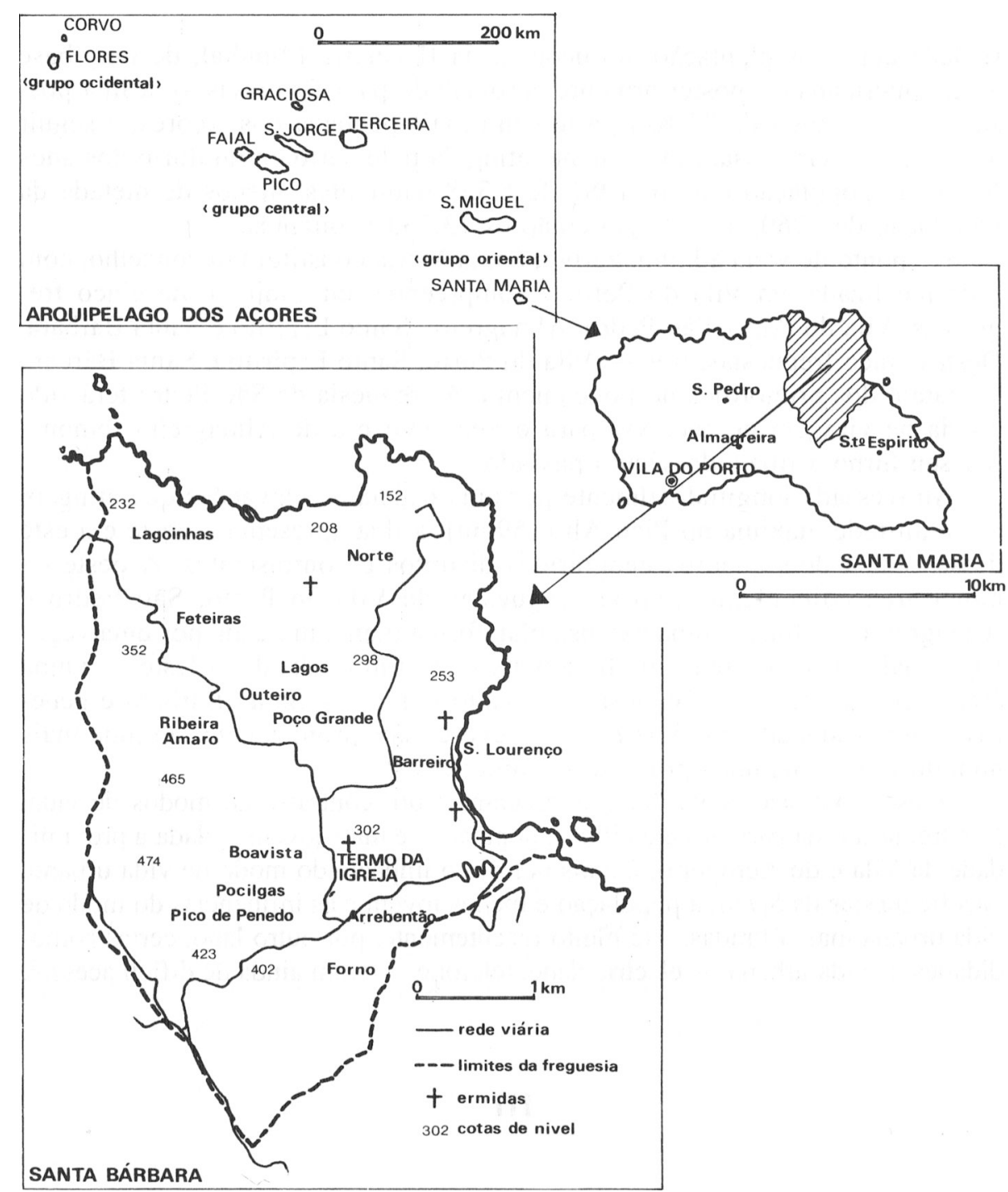

MAPA 1

A freguesia de Santa Bárbara

II

Santa Maria constitui a ilha simultaneamente mais meridional e mais oriental do arquipélago dos Açores. Tendo conhecido um período de relativa noto- 


\section{AS FESTAS DO ESPÍRITO SANTOSNOS AÇORES}

riedade com a implantação, no decurso da II Guerra Mundial, de urna base aérea americana - posteriormente aproveitada para fins civis - a ilha possui uma área total de $97 \mathrm{Km}^{2}$, a terceira mais pequena dos Açores, a seguir ao Corvo e à Graciosa. Severamente atingida pelo surto emigratorio dos anos 60, a sua população era em 1981 de 6.338 habitantes, menos de metade da população de 1960, que atingia então os 13.233 habitantes.

Do ponto de vista administrativo, Santa Maria constitui um concelho, com sede localizada em Vila do Porto e compreende um conjunto de cinco freguesias: Vila do Porto, São Pedro, Almagreira, Santo Espírito e Santa Bárbara. Destas cinco freguesias, três - Vila do Porto, Santo Espírito e Santa Bárbara - datam dos primórdios do povoamento. A freguesia de São Pedro terá sido criada na viragem do séc. XVI para o Séc. XVII e a de Almagreira remonta por seu turno a finais do século passado.

Atravessada longitudinalmente por uma cadeia de elevações que atingem a sua altitude máxima no Pico Alto $(590 \mathrm{~m})$, a ilha apresenta a oeste e a este dessa cadeia dois quadros geográficos distintos e contrastantes. A oeste numa área coincidente com as freguesias de Vila do Porto, São Pedro e Almagreira - situa-se uma extensa plataforma plana, marcada por uma vegetação mais escassa e por um clima mais seco. Em contraste, a leste - numa área correspondente às freguesias de Santo Espírito e Santa Bárbara e genericamente designada por Serra - o relevo é mais pronunciado, o clima mais húmido e os solos mais profundos e produtivos ${ }^{1}$.

A este contraste geográfico, acrescenta-se um contraste de modos de vida. Nas freguesias da parte leste da ilha, a população é mais jovem e, dada a proximidade da Vila e do Aeroporto, é mais notório o impacte do modo de vida urbano. Nas freguesias da Serra, a população é menos jovem e as influências do modo de vida urbana mais filtradas. Até muito recentemente, por outro lado, certas comodidades da vida urbana - electricidade, telefone - eram ainda de difícil acesso ${ }^{2}$.

\section{III}

Com uma área de $26,65 \mathrm{Km}^{2}$, a freguesia de Santa Bárbara possuía em 1987 uma população de 617 habitantes correspondentes a 214 grupos domés-

\footnotetext{
${ }^{1}$ Para uma apresentação mais detalhada dos aspectos geográficos de Santa Maria, cf. Neves, 1959 e Constância, 1982

${ }^{2}$ No centro de Santa Bárbara, durante os anos iniciais da minha pesquisa - em 1982 e 1983 - apenas 4 ou 5 casas dispunham de telefone e, embora fossem já poucas as que não tinham electricidade, apenas cerca de uma dezena possuía televisão. Como se imagina, nos lugares periféricos, a situação era pior. Em 1987, embora este quadro tenha evoluído favoravelmente, alguns lugares periféricos continuavam a não dispor de electricidade.
} 


\begin{tabular}{lcc}
\hline \multicolumn{1}{c}{ LUGAR } & $\begin{array}{c}\text { UNIDADES } \\
\text { DOMÉSTICAS }\end{array}$ & HABITANTES \\
\hline São Lourenço & 9 & 29 \\
Forno & 4 & 16 \\
Arrebentão & 45 & 114 \\
Pocilgas & 5 & 13 \\
Pico do Penedo & 9 & 37 \\
Boavista & 17 & 54 \\
Termo da Igreja & 53 & 142 \\
Barreiro & 10 & 38 \\
Norte & 10 & 24 \\
Poço Grande & 11 & 39 \\
Outeiro & 5 & 17 \\
Lagos & 4 & 12 \\
Ribeira do Amaro & 2 & 4 \\
Feteiras & 18 & 55 \\
Lagoinhas & 12 & 26 \\
& 214 & 620 \\
\hline
\end{tabular}

\section{QUADRO 2}

Distribuição da população por lugares em Santa Bárbara (1987)

ticos ${ }^{1}$. Esta população distribuía-se de forma desigual pelos diferentes lugares - ou termos - em que a freguesia se divide (cf. quadro 2).

Destes lugares o mais importante é o Termo da Igreja, que desempenha as funções de lugar central. É lá que se situam a igreja paroquial, o cemitério, a sede da Junta de Freguesia, bem como os principais equipamentos sociais e comerciais existentes na freguesia: escola primária, posto de saúde, posto de correio, casa do povo, três mercearias com loja (taberna), etc... De entre os restantes lugares, destacam-se o Norte, onde se situa uma ermida consagrada a Nossa Senhora de Lourdes, e São Lourenço - ou Fajã, como também é localmente designado ${ }^{2}$. Este último lugar, situado

\footnotetext{
${ }^{1}$ Os dados aqui apresentados resultam do «levantamento de vizinhos» por mim efectuado na freguesia, no decurso do qual foram recolhidos, para cada unidade doméstica, elementos relativos à sua composição, relações de parentesco, situação económico-social, situação perante a emigração, etc... Salvo indicação em contrário o conjunto de dados que terei ocasião de apresentar ao longo deste capítulo têm a sua origem neste «levantamento de vizinhos».

${ }^{2}$ Fajã constitui a designação genérica dada nos Açores a uma extensão de terra baixa e plana, situada junto ao mar, formada em geral por materiais desprendidos de uma quebrada. Cf. a este respeito Costa, Carreiro da, 1989: 34-37.
} 
junto ao mar e onde predomina a cultura da vinha, embora possua uma população fixa baixa, é utilizado como estância de férias durante o Verão por inúmeras famílias da Vila e, mais recentemente, por emigrantes da própria freguesia, que construíram lá casas. Três ermidas - consagradas a Jesus, Maria, José, São Lourenço e Nossa Senhora do Desterro - fazem parte do equipamento religioso do lugar.

Com excepção do Termo da Igreja, onde se tem vindo a desenvolver recentemente uma certa tendência no sentido de uma maior concentração, o padrão dominante de povoamento é de extrema dispersão, uma das mais elevadas aliás que é possível encontrar em todo o arquipélago dos Açores. As casas situam-se a uma certa distância umas das outras, rodeadas do respectivo casal e separadas entre si por terras de cultura ou pastos. Dispondo-se de forma irregular na proximidade das estradas e caminhos, a sua implantação precisa procura ainda tirar partido do carácter bastante acidentado do terreno.

Conforme se depreende do quadro $3^{1}$, os 214 grupos domésticos existentes na freguesia correspondem na sua grande maioria - 77,1\% — a famílias nucleares ou elementares - modelo ideal de organização do grupo doméstico. O número de unidades domésticas alargadas era de $8,4 \%$ e, em toda a freguesia, existia apenas um agregado familiar múltiplo. Os «isolados», finalmente, representavam $13,55 \%$ do total de unidades domésticas.

Genericamente, o grupo doméstico apresenta-se em Santa Bárbara como um agregado de indivíduos unidos por determinadas relações de parentesco, que partilham a mesma residência e operam como uma unidade económica autónoma. Ao contrário do que se passa noutros contextos ${ }^{2}$, não existe na freguesia nenhuma expressão que sintetize estas várias dimensões do grupo doméstico. As designações mais usadas são as de família e casa. A primeira aplica-se ao grupo doméstico enquanto agregado humano. A segunda é utilizada num sentido restrito e salienta sobretudo a vinculação de cada família a um espaço residencial comum e próprio - a casa enquanto edifício de habitação. A autonomia residencial constitui de facto um dos critérios de plena existência social de cada unidade doméstica. Embora possam ser eventualmente adoptadas soluções de recurso, o objectivo essencial de um novo casal após o casamento é a aquisição ou a construção de uma nova casa. Esta tanto pode situar-se nas proximidades da casa de um dos pais como não. A neolocalidade, designadamente em termos de escolha do lugar de residência, era a solução mais corrente no passado, enquanto hoje em dia se tende a privilegiar a proximidade em relação a uma das famílias de origem.

Enquanto edifício de habitação, a casa corresponde em Santa Bárbara a dois modelos principais: a) casa térrea de um só piso ou com loja — para

\footnotetext{
${ }^{1}$ A terminologia usada na análise da estrutura e composição das unidades domésticas, tanto neste Capítulo, como nos Capítulos 9 e 10, é adaptada de Laslett, 1978.

${ }^{2}$ É o caso de Trás-os-Montes e do Alto Minho. Para Trás-os-Montes cf. O'Neill, 1984, e para o Alto Minho, cf. Pina Cabral, 1986.
} 


$\begin{array}{ll}\text { NUMERO DE } & \text { PERCENTAGEM DE } \\ \text { UN. DOMÉSTICAS } & \text { UN. DOMÉSTICAS }\end{array}$

$\begin{array}{lrr}\text { Isolados } & & \\ \text { Viúvos/as } & 19 & 8,87 \% \\ \text { Solteiros/as } & 10 & 4,67 \% \\ \text { Total } & \mathbf{2 9} & \mathbf{1 3 , 5 5 \%} \\ \text { Agregados não conjugais } & & \\ \quad \text { Irmãos } & 1 & 0,46 \% \\ \text { Outros Parentes } & - & - \\ \text { Sem Parentesco } & - & - \\ \text { Total } & \mathbf{1} & \mathbf{0 , 4 6 \%} \\ \text { Agregados familiares } & & \\ \text { Casal sem Filhos } & 72 & 33,64 \% \\ \text { Casal com Filhos } & 82 & 38,31 \% \\ \text { Viúvos com Filhos } & 2 & 0,93 \% \\ \text { Viúvas com Filhos } & 9 & 4,20 \% \\ \text { Solteiros com Filhos } & - & \mathbf{7 7 , 1 0 \%} \\ \text { Total } & \mathbf{1 6 5} & \\ \text { Agregados familiares alargados } & & 5,14 \% \\ \text { Alargamento ascendente } & 11 & 0,93 \% \\ \text { Alargamento descendente } & 2 & 0,46 \% \\ \text { Alargamento lateral } & 2 & 0,93 \% \\ \text { Outros } & 2 & 0,93 \% \\ \text { Não Parentes } & 2 & \mathbf{8 , 4 1 \%} \\ \text { Total } & \mathbf{1 8} & 0,46 \% \\ \text { Agregados familiares múltiplos } & 1 & \end{array}$

QUADRO 3

Composição das unidades domésticas em Santa Bárbara (1987)

armazenagem de alfaias e produtos agrícolas - com quatro águas; b) casa de dois pisos com duas águas. Este último modelo, de acordo com os testemunhos orais, teria sido introduzido na freguesia no início deste século por emigrantes retornados do Brasil e da América. Quer num quer noutro caso, a casa é caiada de branco, sendo as portas e janelas rodeadas de listas coloridas - as chamadas vistas — em verde ou azul ${ }^{1}$. Estes dois tipos de habitação

${ }^{1}$ A chaminé é um elemento essencial de qualquer um destes tipos de casa, correspondendo a dois modelos centrais: a) chaminé rectangular de «tipo alentejano», que parece ser a mais antiga; b) chaminé redonda de «tipo algarvio» que, de acordo com testemunhos orais, seria de introdução mais recente. 


\begin{tabular}{crrrr}
\hline & TOTAL & CANADÁ & E. U. A. & $\begin{array}{c}\text { OUTROS } \\
\text { DESTINOS }\end{array}$ \\
\hline 1962 a 1969 & 551 & 279 & 251 & 22 \\
1970 a 1979 & 620 & 333 & 298 & 1 \\
1980 a 1987 & 65 & 23 & 39 & 3 \\
Totais & $\mathbf{1 2 3 6}$ & $\mathbf{6 3 5}$ & $\mathbf{5 8 8}$ & $\mathbf{2 6}$ \\
\hline
\end{tabular}

\section{QUADRO 4}

Emigração em Santa Bárbara (1967-1987)

\{Fonte: Livros de Registos de Emigrantes da Câmara Municipal de Vila do Porto)

são largamente dominantes na freguesia, sendo pouco significativa a penetração de tipos de construção mais recentes. Na organização interna do espaço da casa, deve ser salientado o papel da cozinha - onde se situa também o forno de pão. Verdadeiro «centro» da habitação, a cozinha funciona também como espaço de abertura informal para o exterior, em confronto com a sala, que é utilizada em ocasiões de natureza mais cerimonial. A casa é geralmente rodeada do casal, expressão que designa os terrenos adjacentes e os anexos agrícolas neles implantados. Os terrenos adjacentes são fundamentalmente ocupados com culturas hortícolas de consumo corrente, podendo eventualmente alguns deles ser destinados à cultura da batata e do milho. Quanto aos anexos agrícolas compreendem a cerca do porco, um ou dois telheiros - para arrumação de alfaias agrícolas —, o palheiro — utilizado para abrigar o gado no decurso do inverno - e a burra, para secagem e armazenagem do milho ${ }^{1}$.

\section{IV}

Santa Bárbara é uma freguesia profundamente afectada pelo surto migratório que, a partir dos anos 60, atingiu o conjunto das ilhas dos Açores.

\footnotetext{
${ }^{1}$ Este sistema, em que «as espigas são armazenadas conservando grande parte do folhedo e expostas ao ar livre» (Veiga de Oliveira e Pereira, 1982: 72) numa instalação apropriada, é, no quadro português, específico dos Açores (id., ibid.: 73). Tal como noutras ilhas açorianas, a expressão burra é utilizada em simultâneo com outras: estaleiro, tolda, etc... Em Santa Bárbara - e, de uma forma mais geral, em Santa Maria — existem duas variedades principais de burras, correspondentes aos tipos que Veiga de Oliveira e Benjamim Pereira designam de «cafuão» e «tolda» (id., ibid.: 77-82).
} 


\begin{tabular}{cc}
\hline CLASSES ETÁRIAS & $\begin{array}{c}\text { PERCENTAGEM NA } \\
\text { POPULAÇÃO TOTAL }\end{array}$ \\
\hline 0 a 14 anos & $21,48 \%$ \\
15 a 20 anos & $9,53 \%$ \\
21 a 40 anos & $22,13 \%$ \\
41 a 60 anos & $20,51 \%$ \\
mais de 61 anos & $26,33 \%$ \\
\hline
\end{tabular}

\section{QUADRO 5 \\ Classes etárias na população de Santa Bárbara (1987)}

Entre 1962 e 1980, abandonaram a freguesia perto de 1200 habitantes. O Canadá e os EUA absorveram respectivamente cerca de $49 \%$ e $42 \%$ dessa emigração (cf. quadro 4). Nos EUA, os emigrantes fixam-se preferencialmente na costa leste e tanto aí, como no Canadá, as suas ocupações principais situam-se em áreas como a construção civil, indústrias sem exigências de mão-de-obra qualificada, serviços de limpeza, etc... Posteriormente a 1980 o movimento de saídas decresceu de forma significativa, devido sobretudo ao «congelamento» da emigração nos países de destino.

Actualmente parece esboçar-se de novo uma maior abertura, designadamente no Canadá, e muitos casais jovens, impedidos de o fazerem antes, falam de novo em emigrar.

A particular amplitude que atingiu em Santa Bárbara o surto migratório teve consequências demográficas profundas na freguesia. A população actual da freguesia representa pouco mais de $1 / 3$ da população que a freguesia possuía em 1960: 1750 habitantes. Dado tratar-se de uma emigração de famílias inteiras, o número de grupos domésticos sofreu também uma redução da mesma ordem: de um total de 626 em 1960 para 214 na actualidade.

Os efeitos deste decréscimo extremamente significativo da população fazem-se sentir de forma clara na paisagem da freguesia: em 1981, de acordo com os dados do Recenseamento Geral da População, mais de metade das casas - 211 num total de $407^{1}$ — encontravam-se «fechadas». Este processo de despovoamento atingiu dimensões particularmente importantes em certos lugares mais periféricos. Nas Pocilgas, entre 1960 e 1987, a população baixou 80\%; em 1981, o número de casas desabitadas era de 18, contra 5 habitadas. No Norte observa-se também uma tendência semelhante: o decréscimo da população atingiu os $85 \%$, e de um total de 53 casas só 11 se encontravam

\footnotetext{
${ }^{1}$ Estes dados excluem São Lourenço, dado o elevado número de casas com ocupação restringida ao Verão existentes neste lugar.
} 
habitadas. No Forno, por fim, o decréscimo populacional foi de $83,5 \%$ e num total de 18 casas, só 3 se encontravam habitadas.

Simultaneamente, a emigração provocou também um sensível envelhecimento da população, expresso quer numa pirâmide de idades desequilibrada (cf. quadro 5), quer ainda na elevada proporção de grupos domésticos sem filhos e de viúvos e viúvas - com ou sem filhos - no total dos grupos domésticos da freguesia: 93 em 214, isto é, cerca de $43 \%$.

Além das suas consequências estritamente demográficas, a emigração é também responsável por uma certa recessão do modo de vida rural, particularmente bem expressa na situação de subaproveitamento em que se encontra uma parte importante das terras da freguesia. Assim, em contraste com o aproveitamento total e minucioso de que a terra era objecto no período anterior à emigração, cerca de $42 \%$ da área da freguesia - de acordo com os dados do Recenseamento Agrícola dos Açores de 1985 (S.R.E.A., 1985) correspondia a incultos.

Embora afectado pela emigração, o modo de vida rural continua entretanto a ser dominante na freguesia. Mais de metade das suas casas têm na agricultura e na criação de gado vacum a fonte exclusiva ou principal dos seus rendimentos. Quanto às restantes unidades domésticas, dividem-se em três grandes grupos. Num primeiro localiza-se um conjunto de casais ou de viúvos (ou viúvas) já de idade avançada e sem filhos que, embora consagrando-se tradicionalmente à agricultura, se encontram actualmente excluídos da vida activa, dependendo a sua subsistência de reformas e pensões, eventualmente combinadas com remessas de dinheiro de filhos emigrados. Num segundo grupo, situam-se aquelas casas cuja subsistência está sobretudo dependente do exercício - geralmente pelo cabeça de casal - de uma profissão assalariada nãò agrícola, quer em serviços da administração regional e local, quer no sector da construção. Finalmente, dum terceiro grupo fazem parte as casas de emigrantes retornados à freguesia - que representam cerca de $20 \%$ do total das casas - cujos rendimentos derivam sobretudo das poupanças realizadas no decurso da emigração e de reformas pagas a partir dos E.U.A. ou Canadá. Apesar de uma parte significativa dos seus rendimentos provir de actividades não-agrícolas, estas casas mantêm entretanto vínculos importantes com o modo de vida rural. Por um lado, muitas continuam a possuir terra. Por outro, praticam uma agricultura de pequena escala que é designadamente suposta fornecer o essencial dos consumos alimentares do grupo doméstico.

As principais produções agrícolas da freguesia são constituídas pelo trigo - cuja cultura, embora em declínio, ocupava em 1985 uma área de 20 ha -, 
o milho -50 ha - a vinha -33 ha - e a batata -15 ha - , além de produtos hortícolas diversos (inhame, batata doce, etc...) (S.R.E.A., 1985). As técnicas empregues, embora possuam ainda maioritariamente características tradicionais, têm vindo a abrir-se gradualmente a meios mais modernos, existindo actualmente na freguesia três tractores e uma debulhadora de trigo.

A par destas produções agrícolas tradicionais tem aumentado a importância da criação de gado, em virtude quer da sua menor exigência de mão-de-obra, quer da disponibilidade de terra existente. Cerca de 494 ha - isto é, 70\% do total da Superfície Agrícola Útil - corresponde a pastos (S.R.E.A., 1985), elevando-se a 800 os efectivos totais da cabeças de gado.

Com um aproveitamento de derivados - leite, manteiga, etc... - praticamente irrelevante, o gado destina-se sobretudo a venda para abate. Uma parte importante é exportada, vivo, para o continente, em embarques que têm lugar nos meses de Maio, Junho e Julho. A produção estritamente agrícola, entretanto, destina-se sobretudo aos consumos domésticos.

A exploração da propriedade é conduzida com recurso dominante ao trabalho familiar, sendo o trabalho à jorna e as trocas de mão utilizadas de forma complementar. Estas últimas baseiam-se em princípios da mais estrita reciprocidade e têm uma importância particularmente acentuada. Certas operações do ciclo agrícola - em particular as relacionadas com as colheitas - exigem por seu turno a formação de grupos de trabalho extensos, também com base em princípios da ajuda gratuita e recíproca. A divisão sexual do trabalho é extremamente rígida. O pai e os filhos solteiros têm a seu cargo tudo o que se refere ao gado e ao trabalho nos campos. As mulheres, de acordo com uma tendência mais geral prevalecente noutras ilhas açorianas - e que, ao longo dos tempos, chamou a atenção de etnógrafos ou simples observadores $^{1}$ - encontram-se completamente excluídas dessa esfera e movem-se fundamentalmente no interior da casa e no casal. Têm a seu cargo a preparação da alimentação — com relevo para o cozer do pão — cuidam da horta e do porco, etc... O dote tradicional oferecido aos noivos pelos pais - um sacho para o noivo, uma peneira para a rapariga - traduzia de forma particularmente clara esta organização complementar dos mundos masculino e feminino, que se reflecte ainda num ditado frequentemente evocado na freguesia, de acordo com o qual «a mulher conhece-se pelo comer/ e o homem pelo andar».

A estrutura da propriedade baseia-se na pequena e média propriedade. Do total de 214 explorações agrícolas recenseadas em 1985, 96 exploravam

\footnotetext{
${ }^{1}$ É o que se passa na Terceira. «Nunca ali — diz um autor citado por Leite de Vasconcelos - se verão mulheres descalças ou ocupadas em pesados trabalhos agrícolas. A vida delas decorre toda em casa, cuidando do marido e dos filhos» (in Vasconcelos, 1958: 600). Frederico Lopes, também a propósito da Terceira, escreveu por seu turno que «as mulheres (...) pouco eram utilizadas no amanho das terras» (Lopes, 1980c: 427).
} 
uma área inferior a 1 ha, 80 uma área entre 1 a 5 ha e 30 uma área superior a $5 \mathrm{ha}^{1}$. O arrendamento, cujo relevo aumentou em consequência da emigração, ocupa um papel importante no regime fundiário local, correspondendo as terras arrendadas a cerca de $34 \%$ da Superfície Agrícola Útil (S.R.E.A., 1985). A propriedade é bastante fragmentada — sendo de 7,12 o número médio de blocos por exploração - e a área por bloco muito reduzida — cerca de 0,32 ha (id., ibid.).

\section{VI}

A estratificação social dominante na freguesia distribui as casas por três grandes grupos de «status». No topo da hierarquia encontram-se cerca de uma dezena de casas de lavradores, dispondo de uma exploração de área superior a 5 ha e de um efectivo pecuário considerável. Deste grupo fazem ainda parte: um certo número de casas de agricultores a part-time que combinam uma exploração agrícola e um efectivo pecuário importantes com um emprego bem remunerado; algumas casas de ex-emigrantes que a par de uma reforma e de poupanças consideráveis, mantêm uma exploração agrícola relativamente dinâmica; e, por fim, os comerciantes locais. Na camada intermédia - que é a mais numerosa - situam-se: a maior parte das explorações agrícolas de média dimensão; a maioria dos agricultores a part-timel a quase totalidade das casas de ex-emigrantes. Trata-se de um grupo naturalmente muito diversificado. $\mathrm{Na}$ base do sistema social, por fim, situam-se sobretudo dois tipos principais de casas: casais de idade sem filhos e viúvos ou viúvas sem condições para trabalhar de forma regular a terra e vivendo sobretudo de pensões; casais jovens sem terra que retiram o seu sustento do trabalho assalariado, combinado com a exploração, para fins de consumo familiar, de algumas terras arrendadas.

\footnotetext{
${ }^{1}$ Estes dados são os fornecidos pelo Recenseamento Agrícola dos Açores e englobam tanto as terras efectivamente detidas por cada casa como as terras arrendadas. Tive ocasião de recolher — junto da Secção de Finanças de Vila do Porto — dados relativos à propriedade efectivamente detida por cada casa, que apontam para valores ligeiramente diferentes. De acordo com esses dados, 23,28\% das casas não detinham terra, 31,21\% possuíam menos de 1 ha, 40,74\% entre 1 a 5 ha e $2,64 \%$ possuíam mais de 5 ha.
} 
CAPÍTULO 2

OS IMPÉRIOS 
Na freguesia de Santa Bárbara - como no conjunto da ilha de Santa Maria - as Festas do Espírito Santo são conhecidas pela designação genérica de Impérios ${ }^{l}$. Na sua base encontram-se promessas individuais - de que os motivos mais recorrentes são a saúde e a riqueza - que intercambiam a graça divina solicitada com o patrocínio de um Império num local de culto preciso: a igreja paroquial ou duas das ermidas existentes na freguesia - as ermidas de Nossa Senhora de Lourdes (situada no lugar do Norte) ou de Jesus, Maria, José (situada em São Lourenço). Cada um destes locais de culto possui nas suas imediações dois edifícios de características rituais utilizados exclusivamente no âmbito dos Impérios - a copeira e o teatro.

$\mathrm{O}$ vovente recebe no quadro dos festejos a designação de imperador sendo a sua esposa pelo seu lado designada por imperatriz - operando como o seu principal organizador e oficiante. O imperador é coadjuvado nas suas funções por um grupo de vinte a trinta ajudantes, com designações, insígnias e desempenhos tradicionalmente fixados. Entre esses ajudantes destaca-se

\footnotetext{
${ }^{1} \mathrm{Na}$ descrição etnográfica dos Impérios de Santa Bárbara que é de seguida apresentada procurei reter os aspectos mais importantes da estrutura dos festejos, com sacrifício por vezes de elementos de carácter mais secundário. Para uma descrição mais completa dos festejos, cf. Leal 1984. Na bibliografia disponível acerca dos Impérios de Santa Maria avultam dois artigos (Júlio Cabral, 1903 e Joaquim Cabral, 1921) e ainda o volume «Impérios Marienses (Folclore Açoreano)» de Jaime de Figueiredo (1957). Os elementos fornecidos por estes textos dizem entretanto respeito aos Impérios das freguesias da metade ocidental da ilha, cuja estrutura é em certos aspectos distinta da prevalecente em Santa Bárbara. Embora tenham um horizonte mais largo, os volumes «Pedras de Santa Maria» de Armando Monteiro (1969) e «Memórias da Minha Ilha» de Jacinto Monteiro (1982), fornecem também alguns elementos de interesse acerca dos Impérios. Do ponto de vista histórico, as «Crónicas da Província de São João Evangelista das Ilhas dos Açores» de Fr. Agostinho de Monte Alverne, escritas no decurso do séc. XVII, contêm algumas referências ao culto do Espírito Santo em Santa Maria, com particular destaque para o relato de alguns milagres operados pelo Espírito Santo (Monte Alverne, 1986: 97-98).
} 
a folia, que asssegura, por intermédio de um conjunto de cânticos de características tradicionais, a direcção e o acompanhamento musical dos festejos.

A Coroa do Espírito Santo, forma consagrada de representação da divindade, constitui o elemento em torno do qual se estruturam os Impérios. Trata-se de uma Coroa em prata trabalhada, encimada por uma pomba, e que constitui a insígnia central de um conjunto de que fazem ainda parte um ceptro - também encimado por uma pomba - e uma salva, ambos em prata. Em Santa Bárbara existem três dessas Coroas, cada uma delas adscrita aos locais de culto atrás mencionados. Esta forma "sui generis» de representação da divindade deve ser, por um lado, relacionada com as origens usualmente atribuídas às Festas do Espírito Santo, que, como vimos, reservam um papel decisivo à figura da Rainha Santa Isabel. E é, por outro lado, solidária de um conjunto de outras designações e insígnias, igualmente retiradas de uma linguagem de poder, que integram a sequência ritual dos Impérios.

Esta é marcada, antes de mais, por um conjunto de ritos e festejos de características religiosas: terços e outras cerimónias de homenagem à Coroa, procissões e cortejos vários, etc... De entre esses ritos destaca-se a coroação, imposição solene da Coroa ao imperador, realizada pelo padre no termo da missa. Simultaneamente, a sequência ritual dos Impérios concede um lugar de relevo a um conjunto de refeições, dádivas e distribuições de alimentos. Circulando exclusivamente no âmbito dos Impérios, esses alimentos podem ser encarados, de acordo com a definição proposta por Ernesto Veiga de Oliveira, como alimentos cerimoniais: «manjares, pratos ou refeições de composição especial que pode ser muito singela mas que reveste quase sempre o aspecto de uma prescrição obrigatória de fundo rigorosamente tradicional (...) e de aceitação geral» (Veiga de Oliveira, 1984m: 205). A articulação de determinadas cerimónias cíclicas no quadro etnográfico europeu com formas de circulação cerimonial do alimento é um facto recorrente ${ }^{1}$. Mas atinge, nas Festas do Espírito Santo em geral e nos Impérios em particular, uma dimensão especialmente expressiva, tanto pela quantidade extremamente significativa de alimentos distribuídos, como pelo número muito elevado de indivíduos e casas abrangidos por essas prestações alimentares.

Tradicionalmente, o período consagrado em Santa Bárbara à realização dos Impérios - o chamado tempo dos Impérios - estendia-se, à semelhança do que se passa no conjunto do arquipélago, ao longo das oito semanas que medeiam entre o domingo de Páscoa e o domingo da Trindade. Os festejos, em número variável de ano para ano, de acordo com as promessas existentes, convergiam preferencialmente para o domingo de Pentecostes - dia em que a Igreja comemora a descida do Espírito Santo sobre os Apóstolos para a $2 .{ }^{a}$ feira imediatamente a seguir - a chamada $2 .{ }^{a}$ feira de Pentecostes

${ }^{1}$ Cf., para Portugal, alguns dos textos inseridos em Veiga de Oliveira, 1984. Ver ainda numa perspectiva comparativa, Van Gennep, 1947. 


\begin{tabular}{|c|c|c|c|}
\hline ANO & $\begin{array}{l}\text { TOTAL DE } \\
\text { IMPÉRIOS }\end{array}$ & $\begin{array}{l}\text { IMPÉRIOS DE } \\
\text { EMIGRANTES }\end{array}$ & $\begin{array}{l}\text { IMPÉRIOS DE } \\
\text { RESIDENTES }\end{array}$ \\
\hline 1964 & 4 & - & 4 \\
\hline 1965 & 3 & 1 & 2 \\
\hline 1966 & 2 & 1 & 1 \\
\hline $\begin{array}{l}1967 \\
(\ldots)\end{array}$ & 5 & 1 & 4 \\
\hline 1970 & 2 & 1 & 1 \\
\hline 1971 & 4 & 3 & 1 \\
\hline 1972 & 6 & 4 & 2 \\
\hline 1973 & 7 & 7 & - \\
\hline 1974 & 6 & 6 & \\
\hline 1975 & 3 & 2 & 1 \\
\hline 1976 & 3 & 3 & - \\
\hline 1977 & 4 & 4 & - \\
\hline 1978 & 6 & 6 & - \\
\hline 1979 & 5 & 5 & - \\
\hline 1980 & 2 & 2 & \\
\hline 1981 & 2 & 1 & 1 \\
\hline 1982 & 5 & 5 & \\
\hline 1983 & 1 & 1 & \\
\hline 1984 & 2 & 1 & 1 \\
\hline 1985 & 4 & 2 & 2 \\
\hline 1986 & 1 & 1 & - \\
\hline 1987 & 4 & 4 & \\
\hline
\end{tabular}

QUADRO 6

Impérios promovidos por emigrantes e Impérios promovidos por locais em Santa Bárbara (1964-1987)

- e para o domingo da Trindade - uma semana depois do domingo de Pentecostes ${ }^{1}$. Era nessas datas que tinha lugar o dia de Império, ponto culminante dos festejos. As semanas que antecediam o dia de Império coinci-

1 A realização de Impérios no domingo da Trindade parece datar, em Santa Bárbara, de finais do século passado. Até então, os Impérios convergiam exclusivamente para o domingo de Pentecostes e, eventualmente para 2. ${ }^{\text {a }}$ feira de Pentecostes. É pelo menos o que se pode depreender do comentário publicado em 1901 num jornal local, segundo o qual «Impérios da Trindade só se faziam na Vila (...). Hoje porém sucede que se fazem Impérios da Trindade não só nas Igrejas paroquiais de fora da Vila, mas num grande número de ermidas, especialmente lá para Santo Espírito e Santa Bárbara» (O Eco Mariense, n. ${ }^{\circ} 2$ de 23/11/1901). 


\begin{tabular}{|c|c|c|c|}
\hline ANO & $\begin{array}{l}\text { TOTAL DE } \\
\text { IMPÉRIOS }\end{array}$ & $\begin{array}{l}\text { IMPÉRIOS } \\
\text { DO TEMPO }\end{array}$ & $\begin{array}{c}\text { IMPÉRIOS } \\
\text { FORA DO TEMPO }\end{array}$ \\
\hline 1964 & 4 & 4 & - \\
\hline 1965 & 3 & 3 & - \\
\hline 1966 & 2 & 2 & - \\
\hline 1967 & 5 & 5 & - \\
\hline \multicolumn{4}{|l|}{$(\ldots)$} \\
\hline 1970 & 2 & 2 & - \\
\hline 1971 & 4 & 4 & \\
\hline 1972 & 6 & 6 & \\
\hline 1973 & 7 & 6 & 1 \\
\hline 1974 & 6 & 6 & \\
\hline 1975 & 3 & 2 & 1 \\
\hline 1976 & 3 & 3 & - \\
\hline 1977 & 4 & 4 & - \\
\hline 1978 & 6 & 6 & \\
\hline 1979 & 5 & 4 & 1 \\
\hline 1980 & 2 & 2 & - \\
\hline 1981 & 2 & 1 & 1 \\
\hline 1982 & 5 & 3 & 2 \\
\hline 1983 & 1 & - & 1 \\
\hline 1984 & 2 & 1 & 1 \\
\hline 1985 & 4 & 2 & 2 \\
\hline 1986 & 1 & - & 1 \\
\hline 1987 & 4 & 1 & 3 \\
\hline
\end{tabular}

diam com a sua fase preliminar e eram ocupadas com um certo número de cerimónias preparatórias. Enquanto estas se centravam em casa do imperador, o dia de Império decorria por seu turno na igreja ou ermida para a qual o Império havia sido prometido.

Esta organização temporal dos Impérios conheceu nos últimos 25/30 anos algumas transformações. Estas ficam a dever-se à generalização, a partir do início do surto migratório dos anos 60 , de Impérios prometidos por emigrantes. Resultantes na maior parte dos casos de promessas relacionadas com a emigração - «se eu for para a América (ou para o Canadá) e que tenha sorte, prometo um Império à Senhora de Lourdes (ou a Santa Bárbara)...» - esses Impérios representam cerca de $75 \%$ do total de Impérios realizados na fre- 
guesia entre 1964 e 1987 (cf. quadro 6) ${ }^{1}$. Muitas pessoas referem a este propósito, em tom de brincadeira, que «se não fossem os emigrantes, os Impérios já tinham acabado» ${ }^{2}$. De facto, contrariamente ao que se passa noutros contextos (cf. Boissevain, 1992), a emigração tem operado em Santa Bárbara não como um factor de enfraquecimento da festa, mas, antes, como um instrumento da sua continuidade e reforço.

Esta estreita dependência entre Impérios e emigração conduziu em primeiro lugar ao aumento do número dos chamados Impérios fora do tempo. Muitos dos emigrantes apenas conseguem deslocar-se à freguesia nos meses consagrados às férias e um certo número de Impérios passou em consequência a realizar-se nesse período (cf. quadro 7). Como essas deslocações têm também uma duração máxima de três/quatro semanas deu-se simultaneamente uma contracção da fase preliminar dos Impérios. Assim, em vez das sete/oito semanas tradicionalmente previstas, os Impérios estendem-se actualmente por um período de duas/três semanas.

Apesar destas transformações, os Impérios conservaram entretanto intactas grande parte das suas características tradicionais.

A sua realização requer antes de mais, como vimos, a formação de um extenso grupo de ajudantes, escolhido pelo imperador e encarregue de o coadjuvar nas tarefas de ordem prática e nos desempenhos cerimoniais requeridos pelo Império. A direcção do grupo está confiada ao copeiro. Com funções particularmente importantes de direcção e organização na esfera da circulação do alimento, o copeiro opera ainda como orientador geral do Império, de que é um especialista local. E nele que de alguma forma o imperador delega as suas competências de organizador principal do Império. Na freguesia existem actualmente dois copeiros em actividade, sendo de salientar que ambos ocuparam ou ocupam ainda importantes funções de liderança no contexto local. Um deles

\footnotetext{
${ }^{1}$ Quer o quadro 1, quer os quadros 2, 3 e 6 foram elaborados a partir dos requerimentos dirigidos à Câmara Municipal de Vila do Porto, pedindo autorização para abate do gado fora do matadouro por ocasião dos Impérios. Como essa autorização só foi tornada obrigatória a partir do início dos anos 60, apenas é possível dispor de dados a partir de 1964. Não me foi entretanto possível localizar os requerimentos referentes aos anos de 1968 e 1969. Todos os dados foram depois confirmados e ampliados por intermédio de uma recolha oral de informação.

${ }^{2}$ Este vínculo entre os Impérios e a emigração exprime-se também na recriação dos festejos nos países de acolhimento dos emigrantes. Nos EUA realizam-se Impérios promovidos exclusivamente por marienses em Saugues, desde 1927 (cf. Baluarte, II série, n. ${ }^{\circ} 3$, 1/7/1977), em Hartford, Conn., desde 1976, e em Taunton e Hudson, desde 1978 (cf. Baluarte, II série, n. $\left.{ }^{\circ} 17,1 / 9 / 1978\right)$.
} 
exerceu, durante alguns anos, o cargo de Presidente da Junta de Freguesia, enquanto o outro foi Presidente da Assembleia de Freguesia; ambos desempenharam ainda funções de relevo nas instâncias administrativas da paróquia. Esta associação entre o cargo de copeiro e a liderança local é recorrente, reencontrando-se também entre os copeiros que anteriormente exerceram essa função. Um deles foi durante muitos anos escrivão da Junta de Freguesia; outro ocupou as funções de presidente da Junta entre 1956 e 1963; um terceiro, finalmente, foi também presidente da Junta de Freguesia entre 1964 e 1974.

Quanto aos ajudantes propriamente ditos, dividem-se em três grandes grupos. Num primeiro incluem-se aqueles que mais directamente secundam o imperador nos seus desempenhos cerimoniais: os ajudantes grados, os pagens da mesa e a folia. Os ajudantes grados são quatro: o trinchante, o mestre sala e dois briadores (provável corruptela de vereadores); estes últimos cargos devem ser desempenhados por dois rapazes solteiros. Estes ajudantes possuem como principal insígnia distintiva - para além do lenço ao pescoço usado por todos os ajudantes - uma vara de cerca de 2 metros. Em dia de Império usam também um fruteiro enrolado em volta do braço esquerdo e dois deles - o trinchante e o mestre sala - envergam ainda uma toalha branca caída sobre o peito. Os pagens da mesa são em número de dois, escolhidos entre crianças de idades compreendidas entre os quatro e os oito anos. Idealmente, a escolha recai sobre os filhos do imperador. Além dofruteiro, usam ainda como insígnia uma toalha branca a tiracolo. Quanto à folia - que, como vimos, tem a seu cargo o acompanhamento e a direcção musical das principais sequências rituais do Império - é composta pelo mestre, que toca o tambor e dirige, e por dois outros foliões, um que transporta o estandarte do Espírito Santo e outro que toca os testos, um idiofone composto por dois pratos metálicos ${ }^{1}$. Os seus cantares, conhecidos pela designação de alvoradas, possuem características tradicionais particularmente acentuadas, reservando um papel importante à improvisação, e configuram-se ora como cânticos religiosos, ora como enunciados reguladores das diversas sequências rituais do Império. Do reportório da.folia fazem ainda parte cantares de características mais lúdicas, conhecidos sob a designação defalsetes.

Ao lado deste primeiro grupo, conta-se depois um conjunto de doze a quinze ajudantes designados de acordo com as tarefas que lhes estão cometidas em dia de Império, particularmente no âmbito da distribuição de alimentos. Deste grupo fazem parte o ajudante de imperador, o ajudante de trinchante, o copeiro do vinho — também conhecido por ajudante de copeiro sete a dez ajudantes de copeira, quatro a seis ajudantes de portais, um aju-

\footnotetext{
1 Além de Santa Maria, os testos encontram-se também - embora sob uma forma ligeiramente diferente - nas Festas do Espírito Santo das Flores e Corvo. No continente, o único exemplo conhecido da sua utilização situa-se na Beira Baixa, mais uma vez no quadro das Festas do Espírito Santo. Cf. a este respeito, Veiga de Oliveira, 1966, 227-228, e Veiga de Oliveira, 1986, 28-29.
} 
dante da porta da copeira e um ajudante da porta da igreja. Pode também incluir-se neste grupo ofoguista, que tem a seu cargo o lançamento das roqueiras, ou foguetes, no decurso dos festejos.

Num terceiro grupo incluem-se, por fim, os ajudantes encarregues das tarefas de preparação culinária do Império. Entre esses ajudantes contam-se duas cozinheiras, dirigidas por uma mestra ${ }^{1}$ - eventualmente auxiliadas por outras ajudantes femininas sem designações ou atribuições fixas - e dois cozinheiros, coadjuvados por um agueiro e por um escarrilhador.

\section{III}

Como vimos, a estrutura genérica dos Impérios começa por comportar um conjunto de cerimónias e festejos de características mais explicitamente religiosas. Essas cerimónias e festejos centram-se, no decurso da fase preliminar do Império, na casa do imperador, ou, no caso de alguns emigrantes, na casa de um parente chegado residente na freguesia, geralmente os pais ou um irmão. É lá que a Coroa é momentaneamente instalada, num altar erguido expressamente para o efeito. Este altar é montado num dos cantos da divisão principal da casa que recebe a designação de quarto do Espírito Santo. Consiste numa pequena mesa, sobre a qual é colocada uma estrutura de madeira com 4 degraus. O conjunto é coberto com toalhas brancas rendadas. A Coroa é posta no topo do altar, enquanto o ceptro é fixado num pequeno recipiente com grãos de trigo, colocado na base do altar. Por cima do altar é presa ao tecto uma armação circular de vime da qual pendem duas cortinas brancas que se abrem em baixo. Tradicionalmente a ornamentação do altar compreendia, além de um conjunto de castiçais, uma série de decorações florais. A divisão era também profusamente enfeitada com flores, ramos de giesta, etc... Hoje em dia, devido à influência da emigração, generalizou-se também o uso de decorações natalícias ${ }^{2}$.

E em torno do altar que decorre aquela que é a cerimónia religiosa central da fase preliminar do Império: a alumiação. Esta baseia-se num conjunto de cantares em honra e louvor do Espírito Santo entoados pelafolia junto ao altar. Por vezes é também rezado o terço. À cerimónia assistem em geral algumas dezenas de pessoas. A esta componente religiosa, a alumiação junta um importante carácter lúdico. Dos cantares religiosos, passa-se a cantares de

${ }^{1}$ A mestra tem na esfera da confecção do alimento uma importância similar ao copeiro. $\mathrm{Na}$ freguesia, existem actualmente duas mulheres que exercem com regularidade esse cargo.

${ }^{2}$ A decoração do altar e do quarto do Espírito Santo - bem como o conjunto de outras decorações que integram a sequência dos Impérios - é uma tarefa exclusivamente feminina cuja direcção se encontra a cargo da mestra. 
temática profana, por vezes acentuadamente jocosa. Fora do quarto do Espirito Santo sucedem-se as conversas e as canções ao desafío, chegando mesmo a organizar-se improvisados bailes. Tradicionalmente, realizavam-se alumiações em todos os fins de semana do longo período de sete/oito semanas por que se estendia a fase preliminar de um Império, e, ainda, na 5. ${ }^{\mathrm{a}}$ feira de Ascensão. Com a contracção da fase preliminar dos Impérios, entretanto, passaram a realizar-se apenas uma a duas alumiações, a primeira no dia em que a Coroa é instalada em casa do imperador e uma segunda sensivelmente a meio da fase preliminar do Império.

No dia de Império, os festejos centram-se por seu turno na igreja ou ermida para que o Império foi prometido e têm o seu ponto culminante na coroação. Como vimos, esta cerimónia chave do Império consiste na imposição solene da Coroa ao imperador e tem lugar no termo da missa - que é por isso chamada de missa da coroação — sendo realizada pelo padre, de acordo com um cerimonial fixado eclesiásticamente desde finais do século passado: «ajoelhada (...) a pessoa que tiver de coroar, o pároco a aspergirá com água benta e, feita a aspersão, tomará o ceptro e osculando a pombinha, do mesmo modo a dará também a beijar ao imperador que o recebe com a mão direita e o encosta ao ombro esquerdo, segurando-o com ambas as mãos. Feito isto, o pároco recebe a coroa que lhe ministrará o pagem (...) e osculando a pombinha da mesma coroa a dá igualmente a beijar ao imperador e logo a coloca sobre a cabeça do mesmo, entoando ou cantando o hino Veni Creator e, incensando-a em seguida (...), ajoelha enquanto se canta a primeira estrofe do hino. Terminado este e dito o Emitte Spiritum Tuum, (...) o pároco entoa ou canta Oremus (...). Findo o acto da coroação, a pároco vestido da sobrepeliz acompanhará a coroa (...) até à porta da igreja» (Resoluções..., 1895: 133-134).

Para além destas cerimónias, a estrutura religiosa dos Impérios comporta ainda um certo número de cortejos. Estes cortejos assinalam as fases mais importantes dos festejos: a instalação da Coroa em casa do imperador, a sua transferência, no termo da fase preliminar do Império, para a igreja ou ermida onde decorre o dia de Império, a coroação, o fim do Império. Apesar de algumas diferenças em aspectos de detalhe, a estruturação cerimonial destes cortejos obedece a um certo número de características comuns. O imperador, encarregue do transporte da Coroa, constitui a sua figura central; a imperatriz segue a seu lado e ambos são antecedidos pelos pagens da mesa. Os ajudantes grados - que se fazem acompanhar das suas varas - enquadram este grupo central: o trinchante e o mestre sala vão à sua frente, enquanto os dois briadores seguem atrás. Ligeiramente destacado deste grupo e anunciando o cortejo segue a folia, que assegura não só o seu acompanhamento musical, como a sua direcção (figura 1).

A semelhança que estes cortejos possuem com as procissões religiosas correntes deve ser sublinhada. Assim, é usual certos troços do seu itinerário serem atapetados com flores. A sua passagem, as pessoas, abandonando momentaneamente as suas ocupações, adquirem uma atitude de recolhimento, e muitas delas 


\section{A \\ A \\ IMP. $\quad \mathrm{pm}$ \\ $\mathrm{IMP}^{\wedge} \mathrm{pm}$ \\ A \\ FIGURA 1 \\ Organização dos cortejos do Império}

A

Legenda: F — foliões; MS — mestre sala; T — trinchante; pm - pagens da mesa; IMR - imperador; IMR ${ }^{\mathrm{a}}$ - imperatriz; B - briadores;

A - acompanhantes

aproximam-se da Coroa com o objectivo de a beijar. O seu decurso é ainda acompanhado pelo contínuo estralejar das roqueiras e pelo repicar dos sinos.

\section{IV}

É em articulação com estas cerimónias de natureza mais estritamente religiosa que têm lugar o conjunto de refeições, dádivas e distribuições alimentares que integram a sequência ritual dos Impérios.

Estas baseiam-se num certo número de alimentos tradicionalmente definidos, entre os quais avultam as Sopas de Espírito Santo e um conjunto de variedades de massa sovada. As Sopas do Espírito Santo - cuja confecção compete aos cozinheiros — são feitas à base de carne de rês cozida, de fatias de pão de trigo e de um tempero de canela e hortelã. A sua feitura requer o abate de um certo número de reses - vacas, vitelas ou bois - cuja carne é também aproveitada sob a forma de prestações cruas. A massa sovada é por seu turno confeccionada com farinha de trigo, ovos, açúcar, manteiga, banha e fermento. No âmbito dos Impérios, são preparados três tipos distintos de pães de massa sovada: escaldadas, pães de mesa e roscas ${ }^{l}$. Além destes pães de massa

${ }^{1}$ Um pão de mesa é um grande pão de massa sovada com cerca de $35 / 40 \mathrm{~cm}$ de diâmetro que, para 9/10 maquias de farinha (cada maquia de farinha corresponde sensivelmente a $800 \mathrm{~g}$ ), leva três dúzias de ovos, $1 \mathrm{~kg}$ de açúcar, 3 a 4 colheres de manteiga, 3 a 4 colheres de banha e fermento. A rosca, por seu turno, para 7 maquias de farinha, leva um pouco mais de manteiga e açúcar, além de sumo de limão. A escaldada, por fim, tem as dimensões de um pão de trigo vulgar e é apenas levemente temperada: para 12 maquias de farinha são necessárias 2 dúzias de ovos, $1 \mathrm{~kg}$ de açúcar, $500 \mathrm{~g}$ de manteiga, lima e fermento de milho. 
AS FESTAS DO ESPÍRITO SANTO NOS AÇORES

\begin{tabular}{|c|c|c|c|c|c|}
\hline ANO & IMPÉRIOS & $\begin{array}{c}\text { GADO } \\
\text { ABATIDO }\end{array}$ & ANO & IMPÉRIOS & $\begin{array}{c}\text { GADO } \\
\text { ABATIDO }\end{array}$ \\
\hline \multirow[t]{4}{*}{1965} & Império 1 & 10 & 1973 & Império 1 & 7 \\
\hline & Império 2 & 8 & & Império 2 & 9 \\
\hline & Império 3 & 6 & & Império 3 & 3 \\
\hline & & & & Império 4 & 7 \\
\hline \multirow[t]{3}{*}{1966} & Império 1 & 11 & & Império 5 & 7 \\
\hline & Império 2 & - & & Império 6 & 8 \\
\hline & & & & Império 7 & 6 \\
\hline \multirow[t]{5}{*}{1967} & Império 1 & 5 & & Império 8 & 7 \\
\hline & Império 2 & 7 & & & \\
\hline & Império 3 & 6 & 1974 & Império 1 & 3 \\
\hline & Império 4 & 6 & & Império 2 & 6 \\
\hline & Império 5 & - & & Império 3 & 6 \\
\hline \multirow{2}{*}{$(\ldots)$} & & & & Império 4 & 9 \\
\hline & & & & Império 5 & 7 \\
\hline \multirow[t]{2}{*}{1970} & Império 1 & 11 & & Império 6 & 6 \\
\hline & Império 2 & 3 & & Império 7 & 6 \\
\hline \multirow[t]{5}{*}{1971} & Império 1 & 8 & 1975 & Império 1 & 3 \\
\hline & Império 2 & & & Império 2 & \\
\hline & Império 3 & 6 & & Império 3 & 8 \\
\hline & Império 4 & & & & \\
\hline & & & 1976 & Império 1 & 8 \\
\hline \multirow[t]{6}{*}{1972} & Império 1 & 7 & & Império 2 & 8 \\
\hline & Império 2 & 9 & & Império 3 & 6 \\
\hline & Império 3 & 7 & & & \\
\hline & Império 4 & 8 & 1977 & Império 1 & - \\
\hline & Império 5 & 5 & & Império 2 & 5 \\
\hline & Império 6 & 7 & & & \\
\hline
\end{tabular}

sovada, os Impérios exigem ainda a preparação de três qualidades de biscoitos - biscoitos de orelha, biscoitos encanelados e biscoitos de aguardentel — de pães leves — designação localmente atribuída ao pão-de-ló — e, sobretudo, de uma quantidade importante de pães de trigo, usados não só na confecção das Sopas mas também no quadro de outras prestações alimentares. A confecção deste conjunto de alimentos está a cargo das cozinheiras. Por fim, os Impérios requerem ainda o consumo de quantidades significativas de vinho.

1 Os biscoitos de orelha e os encanelados são feitos da mesma massa - para 1 maquia de farinha, 4 ovos, 3 ou 4 colheres de açúcar, 2 colheres de banha, 2 de manteiga, fermento apenas diferindo na forma exterior. Os de orelha desenham uma espécie de triângulo vazado de ângulos arrebitados. Os encanelados, mais pequenos, formam uma pequena circunferência vazada, podendo ser recobertos por açúcar em ponto. Os biscoitos de aguardente levam, para 


\begin{tabular}{|c|c|c|c|c|c|}
\hline ANO & IMPÉRIOS & $\begin{array}{c}\text { GADO } \\
\text { ABATIDO }\end{array}$ & ANO & IMPÉRIOS & $\begin{array}{c}\text { GADO } \\
\text { ABATIDO }\end{array}$ \\
\hline & & & 1982 & Império 2 & - \\
\hline \multirow[t]{3}{*}{1977} & Império 3 & & & Império 2 & 8 \\
\hline & Império 4 & & - & Império 3 & \\
\hline & & & & Império 4 & 8 \\
\hline \multirow[t]{6}{*}{1978} & Império 1 & 3 & & Império 5 & 8 \\
\hline & Império 2 & 8 & & & \\
\hline & Império 3 & 7 & 1983 & Império 1 & 8 \\
\hline & Império 4 & 9 & & & \\
\hline & Império 5 & 8 & 1984 & Império 1 & 9 \\
\hline & Império 6 & 6 & & Império 2 & 8 \\
\hline \multirow[t]{7}{*}{1979} & Império 1 & 11 & & & \\
\hline & Império 2 & 9 & 1985 & Império 1 & 8 \\
\hline & Império 3 & 9 & & Império 2 & 7 \\
\hline & Império 4 & 9 & & Império 3 & 5 \\
\hline & Império 5 & 8 & & Império 4 & 8 \\
\hline & Império 6 & 7 & & & \\
\hline & & & 1986 & Império 1 & 7 \\
\hline \multirow[t]{3}{*}{1980} & Império 1 & 7 & & & \\
\hline & Império 2 & 6 & 1987 & Império 1 & 8 \\
\hline & & & & Império 2 & 8 \\
\hline \multirow[t]{2}{*}{1981} & Império 1 & 11 & & Império 3 & 6 \\
\hline & Império 2 & 11 & & Império 4 & 7 \\
\hline
\end{tabular}

\section{QUADRO 8 \\ Gado abatido para os impérios em Santa Bárbara (1965-1987)}

Os alimentos que passámos em revista circulam nos Impérios em quantidades extremamente importantes e a sua preparação representa um dispêndio cerimonial muito elevado, cujo valor monetário se situa em média entre os 1.500 e os 2.000 contos $^{1}$.

1 maquia de farinha, 8 ovos, 1 cálice de aguardente com meia colher de sal misturada, 1 colher de açúcar, 1 colher de manteiga, 1 colher de banha e uma casquinha de limão. Não levam fermento e a sua forma exterior, circular vazada se vista de cima, apresenta-se, de perfil, estalada a meio.

${ }^{1}$ Salvo indicação em contrário, os valores monetários indicados ao longo do presente capítulo têm como padrão base o ano de 1987. Nesse ano realizaram-se quatro Impérios na fre- 
AS FESTAS DO ESPÍRITOSANTOSNOS AÇORES

\begin{tabular}{|c|c|c|c|c|}
\hline & $\begin{array}{l}\text { PRIMEIRO } \\
\text { IMPÉRIO } \\
\text { S. BARBARA }\end{array}$ & $\begin{array}{l}\text { SEGUNDO } \\
\text { IMPÉRIO } \\
\text { S. BÁRBARA }\end{array}$ & $\begin{array}{c}\text { PRIMEIRO } \\
\text { IMPÉRIO } \\
\text { NORTE }\end{array}$ & $\begin{array}{c}\text { SEGUNDO } \\
\text { IMPÉRIO } \\
\text { NORTE }\end{array}$ \\
\hline \multicolumn{5}{|l|}{ Pães de mesa } \\
\hline e roscas & 86 & 104 & 55 & 88 \\
\hline Outras ofertas & 46 & 70 & 65 & 58 \\
\hline a) géneros & & 14 & & 12 \\
\hline b) dinheiro & & 56 & & 46 \\
\hline Total & 132 & 174 & 120 & 146 \\
\hline
\end{tabular}

A parte mais importante desse dispêndio é o requerido pelo gado. Um Império envolve em geral o abate de um número médio de sete a nove cabeças de gado, cujo custo representa uma despesa média situada entre os 700 e os 1.000 contos. Entretanto - como se depreende do Quadro 8, relativo à totalidade dos Impérios realizados em Santa Bárbara entre 1965 e 1987 - tem havido casos de Impérios que abateram um total de onze reses. Foi o que se passou em 1966, 1970, 1979 e 1981. Em 1989, houve mesmo um Império - o mais forte que alguma vez se realizou não apenas em Santa Bárbara, mas em toda a ilha de Santa Maria - que abateu doze reses. Por outro lado, o dispêndio com o gado pode em certos casos atingir valores mais altos do que aqueles que referimos atrás. É o que se

guesia. O primeiro realizou-se na igreja paroquial de Santa Bárbara, no domingo de Pentecostes - que nesse ano recaiu a 7 de Junho - e teve à sua frente um emigrante retornado há cerca de seis meses à freguesia. Os restantes três Impérios foram promovidos por emigrantes que se deslocaram expressamente à freguesia. Um deles realizou-se também na igreja de Santa Bárbara, a 19 de Julho. Quanto aos outros tiveram por seu turno lugar na ermida de Nossa Senhora de Lourdes (Norte) a 9 e 16 de Agosto respectivamente. No decurso do texto estes Impérios serão designados respectivamente por Primeiro Império de Santa Bárbara, Segundo Império de Santa Bárbara, Primeiro Império do Norte e Segundo Império do Norte. Estas designações inspiram-se em formas usadas localmente para identificar os Impérios. Entre estas, de facto, é comum a identificação do Império ser feita por referência à igreja/ ermida ou lugar em que ele se realiza - Santa Bárbara, Norte, Senhora de Lourdes, São Lourenço, etc... - combinada, caso haja mais de um Império num desses locais, com a indicação da ordem cronológica que ele ocupa - primeiro, segundo, terceiro, etc... Outras formas de designação local dos Impérios repousam sobre a indicação da data em que ele teve ou terá lugar, ou sobre a identificação do respectivo imperador. No caso vertente teríamos, de acordo com o primeiro critério, os Impérios de 7 de Junho, 19 de Julho, 9 de Agosto e 16 de Agosto e, de acordo com o segundo, os Impérios de Manuel da Eira, Agostinho Andrade, António Bairos e João de Melo. 
passa com os Impérios que, entre as cabeças de gado para abate, incluem uma junta de bois, cujo valor se aproxima dos 500 contos. Em Santa Bárbara, tomei conhecimento de três desses Impérios, todos eles realizados nos últimos 20 anos.

Os gastos requeridos pela preparação das diferentes massas e pães atinge também valores muito significativos. A parte mais importante refere-se aos pães de mesa e roscas. Preparados em quantidades que, nos casos mais expressivos, são superiores a uma centena, eles envolvem um dispêndio global de $800 \mathrm{~kg}$ de farinha e de 300 dúzias de ovos. A preparação do pão de trigo e das restantes massas exige pelo seu lado cerca de $850 \mathrm{~kg}$ de farinha, e o gasto com o vinho, por fim, pode atingir os 700 litros $^{1}$.

O imperador, no quadro das funções que assume no âmbito dos Impérios, além de ter a seu cargo a confecção e a distribuição da maior parte dos alimentos, é ainda o seu principal financiador. A sua contribuição situa-se entre os $30 \%$ e os $60 \%$ do total de despesas e corresponde a um valor médio situado entre os 400 e os 700 contos.

Os restantes 40 a $70 \%$ provêm, pelo seu lado, da contribuição de um conjunto amplo de outras casas que, mediante ofertas tradicionalmente regulamentadas, se associam ao dispêndio individual do imperador. Essas ofertas, cujo número oscila entre as cento e vinte e as cento e oitenta, recebem a designação de irmandade e dividem-se em três grandes grupos (cf. Quadro 9). O primeiro compreende aquela que é a forma tradicional dominante da irmandade: a oferta de um pão de mesa ou rosca, preparado pela casa que realiza essa oferta. Deste grupo fazem ainda parte os provimentos de mesa constituídos por um pão de mesa, uma rosca e um pão leve. Este primeiro grupo de ofertas, que corresponde a cerca de 50 a $60 \%$ do total das ofertas, tem uma importância decisiva: de facto, a quase totalidade dos pães de mesa e roscas distribuídas no quadro do Império resulta justamente destas irmandades. Um segundo grupo compreende um conjunto de dádivas feitas em dinheiro. A grande maioria dessas ofertas - cuja importância tem vindo a aumentar nos últimos 20/30 anos - toma como padrão o valor monetário atribuído a um pão de mesa ou a uma rosca: cerca de 2.500/3.000 escudos. Outras, porém, apresentam valores superiores. Um certo número de entre elas resulta de contribuições de emigrantes e é geralmente feita em moeda canadiana ou americana. No conjunto, estas ofertas correspondem a cerca de 40 a $50 \%$ do total das contribuições, podendo atingir um quantitativo global de cerca de 200/300 contos. Por fim, um terceiro grupo de irmandades - correspondente a 10 a $20 \%$ do total de ofertas - compreende as dádivas em géneros: vinho, trigo,

${ }^{1}$ Além do vinho, a maior parte dos imperadores adquire também quantidades importantes de cerveja e outros refrigerantes, consumidos no decurso das várias tarefas preparatórias do Império. O total de gastos correspondentes aos vários tipos de massas e pães e às bebidas pode elevar-se, nos casos mais expressivos, a cerca de 580/620 contos. 
AS FESTAS DO ESPÍRITO SANTOSNOS AÇORES

\begin{tabular}{lcc}
\hline & $\begin{array}{c}\text { CABEÇAS DE GADO } \\
\text { ABATIDAS }\end{array}$ & $\begin{array}{c}\text { CABEÇAS DE GADO } \\
\text { OFERECIDAS }\end{array}$ \\
\hline $\begin{array}{c}\text { Primeiro Império } \\
\text { de Santa Bárbara } \\
\begin{array}{c}\text { Segundo Império } \\
\text { de Santa Bárbara }\end{array}\end{array}$ & 8 & 3 \\
$\begin{array}{c}\text { Primeiro Império } \\
\text { do Norte }\end{array}$ & 8 & $2 \frac{1}{2} 2$ \\
$\begin{array}{c}\text { Segundo Império } \\
\text { do Norte }\end{array}$ & 6 & 1 \\
\hline
\end{tabular}

\section{QUADRO 10 \\ Cabeças de gado abatidas e cabeças de gado oferecidas (Impérios de 1987)}

milho, cabeças de gado. Estas irmandades assumem uma particular importância pelo peso que têm no financiamento global do Império', como se pode verificar no Quadro 10, em certos casos elas representam $60 \%$ do total dos gastos com o gado.

Além das ofertas recebidas no quadro da irmandade, os imperadores promoviam ainda tradicionalmente um conjunto de peditórios de géneros — trigo, milho e vinho - que tinham lugar no ano anterior ao do Império, por ocasião respectivamente das debulhas de trigo (princípio de Agosto), das vindimas (finais de Agosto, princípios de Setembro) e da apanha do milho (em Setembro/Outubro). Entretanto, e desde há cerca de 10/15 anos, esses peditórios tornaram-se mais $\operatorname{raros}^{1}$.

Os alimentos que integram a sequência ritual do Império circulam sob a forma de um certo número de prestações que abrangem um conjunto variável de indivíduos e casas tradicionalmente definido. De acordo com a sequência genérica dos festejos, essas prestações desenrolam-se em primeiro lugar ao longo da fase preliminar do Império, para atingirem o seu ponto culminante em dia de Império.

O início da fase preliminar do Império é marcado por uma série de prestações destinadas exclusivamente aos ajudantes. Além de lhes fornecer a alimentação corrente no âmbito das tarefas preparatórias do Império, o imperador está vinculado para com eles a um certo número de prestações de características mais cerimoniais. A primeira dessas prestações ocorre na véspera do

\footnotetext{
${ }^{1}$ Dos quatro Impérios realizados em 1987, apenas um - o Segundo Império de Santa Bárbara - promoveu esses peditórios. O produto apurado foi de 12 alqueires de trigo, 13 alqueires de milho e 10 mil escudos em dinheiro.
} 


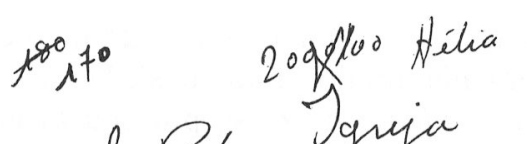

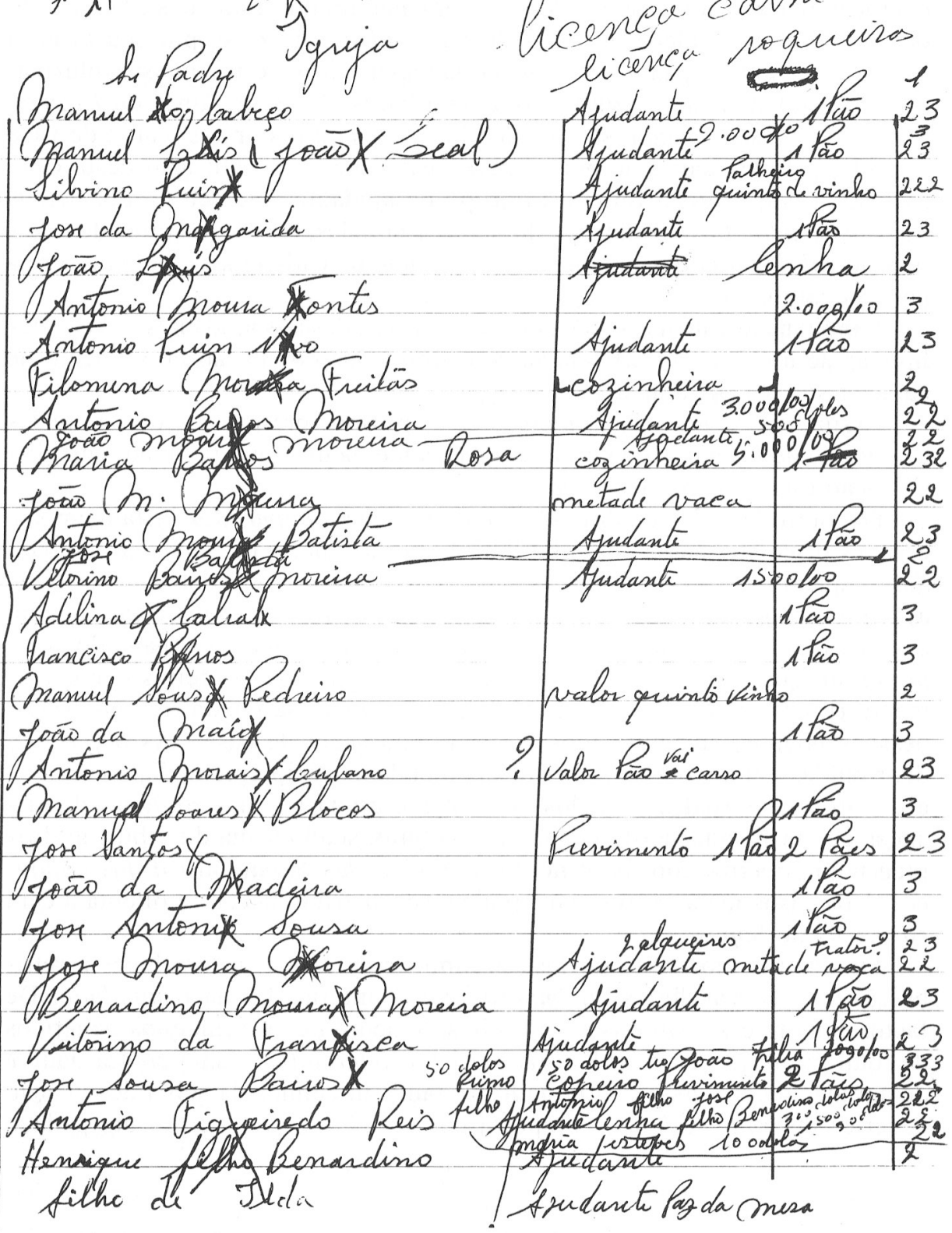

Extracto de um rol da irmandade (Santa Bárbara 1987) 
dia em que a Coroa é instalada em casa do imperador e consta de uma distribuição porta-a-porta de escaldadas por cada um dos ajudantes ${ }^{1}$. No dia em que a Coroa é instalada em casa do imperador, realiza-se por seu turno a Ceia dos Ajudantes, uma refeição de características cerimoniais exclusivamente destinada aos ajudantes e seus familiares. Além de Sopas do Espirito Santo e de massa sovada, são preparados vários outros pratos: carne de vaca guisada, galinha, carne de porco, peixe frito, etc... A realização desta Ceia assinala a constituição formal do grupo de ajudantes: no seu termo, depois de o imperador fazer a entrega dos lenços àqueles, o copeiro procede à leitura do rol dos ajudantes, anunciando o nome de cada um, bem como o respectivo cargo.

Simultaneamente a estas prestações consagradas aos ajudantes, a fase preliminar de um Império articula-se com formas de circulação do alimento de características mais amplas.

Assim, no decurso das alumiações, as pessoas presentes são convidadas a servir-se de biscoitos de orelha e aguardente, bem como de vinho, cuja distribuição está a cargo dos briadores.

Por outro lado, na madrugada do dia em que o imperador instala em sua casa a Coroa, realiza-se uma distribuição porta-a-porta de Sopas do Espírito Santo, que, além dos ajudantes, abrange ainda dois grupos distintos de casas: a) a totalidade dos vizinhos do lugar de residência do imperador, ou, no caso de lugares mais pequenos, a totalidade dos vizinhos do chamado compromisso, que constitui um agrupamento de lugares para efeitos exclusivamente rituais; b) todas as casas da freguesia onde se encontrem enfermos, pessoas doentes ou muito idosas que já não saem de casa ${ }^{2}$. As Sopas são distribuídas em caboucas - designação dada ao recipiente de barro em que elas são transportadas - pelos ajudantes e ainda por um conjunto de crianças e rapazes que se oferecem para o efeito, sendo a sua distribuição dirigida pelo copeiro, com base no chamado rol das Sopas ou rol das caboucas. Nos casos mais expressivos, podem ser distribuídas entre oitenta a cem caboucas de Sopas.

Finalmente, no termo da fase preliminar do Império, tem lugar a retribuição das ofertas feitas ao imperador por intermédio da irmandade. De facto, embora essas ofertas sejam feitas de acordo com princípios genéricos de total gratuitidade, vinculam na prática o imperador a uma contra dádiva de agradecimento. Essa contra dádiva é também conhecida sob a designação genérica de irmandade e é composta por um pão de trigo e por um pedaço

\footnotetext{
${ }^{1}$ Tradicionalmente, esta distribuição de escaldadas tinha lugar na 5. ${ }^{\text {a }}$ Feira de Ascensão, que era por essa razão conhecida pela designação de $5 .^{a}$ Feira dos Brindeiros (brindeiros é outra das designações por que são conhecidas as escaldadas).

${ }^{2}$ Esta distribuição de Sopas do Espírito Santo, em conjunto com a Ceia dos Ajudantes, requer o abate de uma cabeça de gado.
} 
de carne crua de rês. Além de incidir sobre a totalidade das casas que fizeram irmandades ao Império, esta distribuição abrange ainda os ajudantes, o padre e o sacristão, e um certo número de esmolas feitas a casas mais pobres da freguesia. Nos casos mais expressivos são distribuídas um total de aproximadamente duzentas e cinquenta irmandades, envolvendo o abate de cinco a seis reses.

Estas prestações possuem um valor diferenciado - medido por intermédio da qualidade e sobretudo do peso da posta de carne, que pode oscilar entre os $3 / 4 \mathrm{~kg}$ e os $10 / 15 \mathrm{~kg}$ - de acordo com o próprio valor da oferta que pretendem retribuir. No escalão mais baixo, encontram-se as irmandades correspondentes a pães de mesa e roscas, ou a ofertas monetárias de valor equivalente, bem como as esmolas feitas a casas mais pobres. Num segundo escalão, incluem-se as irmandades destinadas aos ajudantes e as que retribuem os provimentos de mesa e um certo número de ofertas em dinheiro e em géneros de valor intermédio. Num último escalão, por fim, encontram-se as irmandades correspondentes às ofertas em cabeças de gado e a somas mais elevadas de dinheiro.

Orientada pelo copeiro com base no rol da irmandade, a distribuição da irmandade encontrava-se tradicionalmente a cargo dos briadores. Hoje em dia, porém, é assegurada pelo conjunto dos ajudantes do Império que, em grupos de dois, percorrem as várias casas da freguesia. Na maior parte delas está preparada uma pequena mesa com biscoitos e vinho doce de que os ajudantes são convidados a servir-se.

Para além desta retribuição imediata, o imperador está ainda vinculado à eventual retribuição diferida das ofertas recebidas no quadro da irmandade. Caso alguma das casas que lhe tenha feito uma oferta venha por seu turno a realizar um Império, ele deve retribuir com uma dádiva da mesma natureza e valor. Inversamente, muitas das irmandades que lhe são oferecidas constituem a retribuição de ofertas anteriormente feitas por ele a outros imperadores.

A distribuição da irmandade é a última prestação alimentar assegurada a partir da casa do imperador. Daí, o centro de gravidade dos festejos transfere-se para a igreja ou ermida para a qual o Império foi prometido, onde têm lugar as refeições e distribuições alimentares que integram a sequência ritual de dia de Império.

Essa transferência dá lugar, como vimos, à organização de um cortejo específico - ò cortejo que leva o Império para a copeira. Este, além da dimensão religiosa comum aos restantes cortejos dos Impérios, possui como traço distintivo uma forte marcação alimentar: em conjunto com a Coroa, são simultaneamente transportados os alimentos necessários ao dia de Império. Imediatamente a seguir à cabeça do cortejo, incorporam-se duas alas compostas maioritariamente por mulheres que transportam os pães de mesa e as 

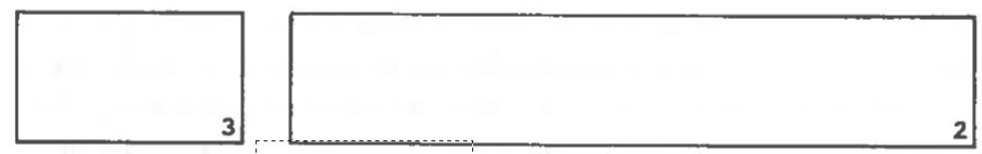

FIGURA 2

Organização do cortejo que leva o império para a copeira

Legenda: 1 - cabeça do cortejo; 2 - pães de mesa e roscas; 3 - carros de bois.

roscas oferecidos ao Império no quadro da irmandade. Estes são profusamente decorados com flores, sendo colocados dentro de um açafate forrado com toalhas brancas rendadas. O seu transporte cabe em princípio a um membro feminino da unidade doméstica que os ofereceu ao Império. Na cauda do cortejo seguem por seu turno dois carros de bois engalanados que asseguram o transporte do pão, da carne, do vinho e das achas necessárias à confecção das Sopas (cf. figura 2).

A própria realização deste cortejo articula-se também com algumas formas de circulação do alimento. Assim é usual o imperador convidar as pessoas que nele se integram a comerem Sopas do Espírito Santo servidas previamente em sua casa. No decurso da marcha, dois ajudantes vão também distribuindo pelas pessoas que assistem à sua passagem e pelas casas que se situam no seu itinerário pedaços de fígado de vaca cozido e fatias de pão de trigo. À chegada do cortejo à copeira - e depois do padre ter procedido à benção dos alimentos - realiza-se uma corrida de vinho entre todas as pessoas que se incorporaram no cortejo.

Do conjunto de refeições e distribuições alimentares que integram a sequência ritual de um Império as mais importantes são as que têm lugar no dia de Império. Centrando-se nos pães de mesa e roscas e nas Sopas de Espírito Santo, elas possuem como traço central o seu carácter generalizado e aberto. A liberalidade e a amplitude como valores genéricos que presidem à circulação do alimento atingem então a sua expressão mais significativa: quem quer que se dirija ao Império é convidado a partilhar do alimento amplamente distribuído ao longo de todo o dia.

As distribuições de pães de mesa e roscas têm por base as ofertas feitas ao Império no quadro da irmandade. Alternam ao longo do dia com corridas de vinho e decorrem no exterior do recinto. São organizadas a partir do teatro - um pequeno edifício de planta quadrangular, nuns casos fechado, noutros «tipo alpendre» — onde, depois da missa da coroação, a Coroa é depositada. 
O seu início ocorre no termo da missa da coroação e dá lugar a uma elaborada cerimónia conhecida sob a designação de abertura da mesa, composta por uma sucessão de cortejos, em que, além dos personagens habituais imperador, imperatriz, pagens da mesa, ajudantes grados e folia - se integra também o padre, encarregue de, no termo da cerimónia, proceder a uma nova benção dos alimentos.

Ao longo do dia, a distribuição de massa sovada encontra-se a cargo dos ajúdantes grados, dois dos quais - o mestre sala e o trinchante - possuem designações que remetem justamente para as funções que asseguram no quadro dessa distribuição. O mestre sala - coadjuvado pelos briadores - está encarregue de dirigir os sucessivos cortejos que procedem ao transporte cerimonial dos pães de mesa e roscas para o teatro. Estes cortejos, conduzidos pela folia, são integrados por um conjunto de quatro a cinco mulheres idealmente escolhidas entre as unidades domésticas que fizeram ofertas ao Império - que asseguram o transporte da massa sovada. O trinchante eventualmente coadjuvado por um ajudante de trinchante - está pelo seu lado encarregue de cortar em fatias os pães de mesa e as roscas. Os briadores, por fim, têm a seu cargo a condução das corridas: a espaços, percorrem o recinto, convidando todas as pessoas a servir-se das fatias de massa sovada, que transportam em açafates. Por cada corrida de massa sovada, realiza-se, imediatamente a seguir, uma corrida de vinho, organizada nos mesmos moldes.

Simultaneamente às corridas de massa sovada e de vinho, o dia de Império é marcado pela distribuição, também ilimitadamente aberta, de Sopas do Espirito Santo ${ }^{l}$. Essa distribuição tem lugar, ao longo de todo o dia de Império, na copeira. Além de uma cozinha - destinada à preparação das Sopas - e de uma sala maior, provida de um conjunto de mesas e bancos corridos - , onde são servidas as Sopas - a copeira possui ainda uma pequena divisão suplementar, conhecida sob a designação de quarto da imperatriz. Essa designação advém-lhe do facto de, durante todo o dia de Império, ser aí que a imperatriz se instala.

A distribuição de Sopas é feita por intermédio de sucessivas mesadas abrangendo entre três a quatro dezenas de pessoas. Além das Sopas propriamente ditas, são ainda distribuídas no decurso da refeição fatias de pão de trigo e dois ou três copos de vinho. O serviço é assegurado por um conjunto de dez a doze ajudantes de copeira, cabendo a distribuição do vinho especificamente ao ajudante de copeiro. O ajudante da porta da copeira está encarregue de orientar a entrada das pessoas na copeira.

Tradicionalmente, a distribuição de Sopas intervinha exclusivamente no dia de Império, iniciando-se após o termo da cerimónia de abertura da mesa. Há cerca de 20 anos, entretanto, generalizou-se o chamado caldo da meia

${ }^{1}$ A confecção das Sopas do Espirito Santo para o dia de Império requer em geral o abate de duas reses. 
noite: uma distribuição de Sopas que tem lugar na noite da véspera ou já na madrugada de dia de Império, e no quadro da qual chegam a ser servidas, apesar do tardio da hora, quatro a cinco mesadas de Sopas.

O carácter generalizado e aberto das prestações alimentares asseguradas em dia de Império atrai, ao longo do dia, milhares de pessoas pertencentes tanto à freguesia de Santa Bárbara, como às restantes freguesias da ilha. O afluxo à copeira, em particular, é muito elevado e nas alturas de maior movimento - ao fim da manhã e durante a tarde — formam-se extensas «bichas» à sua porta. No exterior do recinto e a par das constantes corridas de massa sovada e de vinho, «barracas de comes e bebes», bailes improvisados, despiques entre folias e cantigas ao desafio - opondo por vezes foliões ou cantadores de freguesias diferentes - contribuem para conferir ao recinto uma grande animação e efervescência. Revêem-se conhecidos, acertam-se negócios, multiplicam-se as conversas e as discussões. Em torno da abundância alimentar emblemática desse dia, é a "festa», no sentido mais comum e também mais forte do termo, que acontece. Particularmente valorizado no passado, quando as ocasiões de encontro colectivo eram mais escassas, este ambiente «festivo» é ainda hoje indissociável da imagem do dia de Império.

Marcado sobretudo pelas prestações de carácter generalizado que passámos em revista, o dia de Império articula-se ainda com um certo número de outras prestações, de carácter mais restrito. Assim, na madrugada de dia de Império, tem lugar uma nova distribuição porta-a-porta de Sopas do Espírito Santo. Organizada em moldes genericamente semelhantes à distribuição que tem lugar no dia em que o imperador instala a Coroa em sua casa, esta distribuição incide entretanto sobre algumas categorias diferentes de casas. De facto além dos ajudantes, são agora beneficiados com ela: a) a totalidade dos vizinhos do lugar - ou do compromisso - onde se situa a ermida para a qual o Império foi prometido (em vez dos vizinhos do lugar ou compromisso de residência do imperador); b) as casas com enfermos e pessoas enlutadas - os anojados - à escala da freguesia (os anojados acrescentam-se agora aos enfermos). Nos casos mais expressivos são abrangidas por esta distribuição entre cento e vinte a cento e cinquenta casas.

Alguns destes grupos são ainda objecto de um tratamento particular no quadro das grandes prestações abertas que marcam o dia de Império. Assim os anojados são abrangidos por uma distribuição especial de massa sovada e de vinho que tem lugar imediatamente após o termo da missa da coroação, enquanto decorre a cerimónia da abertura da mesa. Dado o facto de os interditos associados ao luto impedirem a sua continuação no recinto do Império, eles são convidados, à medida que abandonam o Império, a servir-se da massa sovada e do vinho. No passado, por outro lado, era também usual que uma 
das primeiras corridas de massa sovada e de vinho após a abertura da mesa corresse as casas do lugar — ou do compromisso — onde o Império se realizava. Hoje em dia, porém, essa prática apenas se mantém viva em certos Impérios.

No quarto da imperatriz tem também lugar, ao longo de todo o dia de Império, uma distribuição restrita de Sopas, reservada a pessoas convidadas expressamente pelo imperador. Entre essas pessoas contam-se o padre - que, logo a seguir ao termo da cerimónia da abertura da mesa, participa, em conjunto com o imperador e com a imperatriz, numa pequena refeição que lhe é expressamente destinada - eas várias mulheres que, ao longo do dia, asseguram o transporte cerimonial da massa sovada para o teatro.

Por fim, os ajudantes recebem também, ao longo de todo o dia de Império, um tratamento particular. A primeira corrida de massa sovada após a abertura da mesa está-lhes reservada e, além da massa sovada integra também uma ou duas fatias de pão leve. Por outro lado, no decurso do dia, por cada corrida para o geral, realiza-se uma corrida que lhes é especificamente destinada. Finalmente, no termo do dia de Império, após a recolha da Coroa, os ajudantes recebem ainda um convite em massa sovada, que consta de um número muito grande de fatias de pães de mesa ou roscas. No passado realizava-se ainda - sensivelmente a meio do dia — uma refeição reservada aos ajudantes. As distribuições de Sopas na copeira eram momentaneamente interrompidas e os ajudantes reuniam-se para a chamada ceia da copagem.

Iniciando-se, como vimos, sob o signo de prestações destinadas exclusivamente aos ajudantes, é também sob esse signo que um Império termina.

No dia seguinte ao dia de Império realiza-se de facto uma nova Ceia dos Ajudantes, em tudo semelhante àquela que marcou o início da fase preliminar dos festejos ${ }^{1}$. No seu decurso têm lugar as despedidas e agradecimentos formais: a folia, depois de saudar o imperador, agradece a cada um dos ajudantes - através de quadras apropriadas, frequentemente de carácter jocoso a sua participação no Império.

No termo da Ceia, o imperador procede a uma nova distribuição de convites em massa sovada aos ajudantes. Tal como aqueles que foram distribuídos no termo do dia de Império, estes convites finais constam também de quantidades muito grandes de massa sovada.

Além destes convites, o imperador faz também a entrega a cada ajudante de um envelope contendo dinheiro - entre mil a cinco mil escudos, de acordo com o trabalho concreto dispendido por cada um nas tarefas preparatórias do

\footnotetext{
${ }^{1}$ Esta Ceia é conhecida sob a designação de Império dos Velhacos, uma vez que os ajudantes, libertos das responsabilidades do Império, podem então beber à sua vontade.
} 
Império. Este costume é recente, tendo sido introduzido pelos emigrantes. Tradicionalmente, o imperador oferecia apenas a alguns ajudantes - a mestra, os cozinheiros, o copeiro - algumas peças de vestuário - uma camisa, um avental, etc... Esta dádiva final monetarizada é aliás objecto de uma apreciação contraditória. Enquanto muitas pessoas insistem no carácter «gratuito» de que se deve revestir a contribuição dos ajudantes para o Império - «uma pessoa não ajuda pelo dinheiro» - outras salientam, sobretudo em relação aos ajudantes masculinos, a justiça de repor os dias de trabalho perdidos por muito deles.

\section{V}

Os Impérios constituem a modalidade central de que se reveste o culto ao Espírito Santo em Santa Bárbara.

Este compreende simultaneamente um conjunto de outras modalidades «menores», entre as quais começam por avultar as Esmolas e os Jantares.

Tanto as Esmolas como os Jantares têm na sua base, à semelhança dos Impérios, promessas individuais. Mas apresentam em relação aos Impérios uma muito menor elaboração cerimonial. Da sua sequência ritual encontra-se ausente não apenas a Coroa, mas o conjunto de cerimónias de características mais estritamente religiosas que, nos Impérios, se centram nela. As formas de circulação cerimonial do alimento previstas são pelo seu lado de grande simplicidade e assentam exclusivamente no dispêndio cerimonial do vovente - bastante inferior ao requerido por um Império - com exclusão de quaisquer ofertas ou participação da comunidade.

As Esmolas consistem na distribuição de cerca de meia centena de porções de carne de vaca crua e de idêntico número de pães de trigo e de garrafas de vinho. Como sugere a designação de esmola, essa distribuição privilegiava tradicionalmente as casas mais pobres da freguesia. Mas em muitos casos, perante as dificuldades em defini-las de uma forma rigorosa, é adoptado o critério de abranger nessa distribuição, para além de um certo número de famílias à escala da freguesia cujo baixo estatuto económico não oferece dúvidas, a totalidade das casas do lugar ou do compromisso de residência do promotor da Esmola.

1 O total de dinheiro dispendido com estas ofertas monetárias feitas aos ajudantes atinge valores muito significativos. Em 1987, o imperador do Primeiro Império de Santa Bárbara gastou para esse fim 190 contos, o do Segundo Império de Santa Bárbara, 170 contos e o do Segundo Império do Norte de 16 de Agosto, 150 contos. No Primeiro Império do Norte, os envelopes foram substituídos por pequenas ofertas «simbólicas» de objectos adquiridos pelo imperador no Canadá. 
OS IMPÉRIOS

\begin{tabular}{|c|c|c|}
\hline ANO & ESMOLAS & JANTARES \\
\hline 1964 & 1 & \\
\hline 1965 & & - \\
\hline 1966 & & - \\
\hline 1967 & - & 1 \\
\hline \multicolumn{3}{|l|}{$(\ldots)$} \\
\hline 1970 & & 1 \\
\hline 1971 & & - \\
\hline 1972 & & - \\
\hline 1973 & & 1 \\
\hline 1974 & 1 & \\
\hline 1975 & 1 & \\
\hline 1976 & 1 & - \\
\hline 1977 & - & 1 \\
\hline 1978 & & - \\
\hline 1979 & & 1 \\
\hline 1980 & 1 & 2 \\
\hline 1981 & 1 & 1 \\
\hline 1982 & 3 & 1 \\
\hline 1983 & 2 & 4 \\
\hline 1984 & 1 & 2 \\
\hline 1985 & 1 & 1 \\
\hline 1986 & 4 & 1 \\
\hline 1987 & 2 & 2 \\
\hline
\end{tabular}

QUADRO 11

Esmolas e jantares em Santa Bárbara (1964-1987)

Quanto aos Jantares eles consistem fundamentalmente numa distribuição generalizada de Sopas do Espírito Santo numa das três copeiras existentes na freguesia. A sua realização requer o abate de pelo menos uma cabeça de gado e o dispêndio de aproximadamente $220 \mathrm{~kg}$ de farinha e de 380 litros de vinho, correspondentes a uma despesa monetária média de cerca de 200 contos. Tem havido entretanto casos de Jantares onde são abatidas duas reses. Esta distribuição de Sopas tem lugar a um domingo, após o termo da missa, e processa-se em termos gerais idênticos aos dos Impérios. E também usual proceder, na madrugada desse dia, a uma distribuição porta-a-porta de Sopas entre os ajudantes do Jantar - cujo número não ultrapassa em geral os dez -, o conjunto das casas que integram o lugar ou o compromisso da copeira e a totalidade dos enfermos à escala da freguesia. 


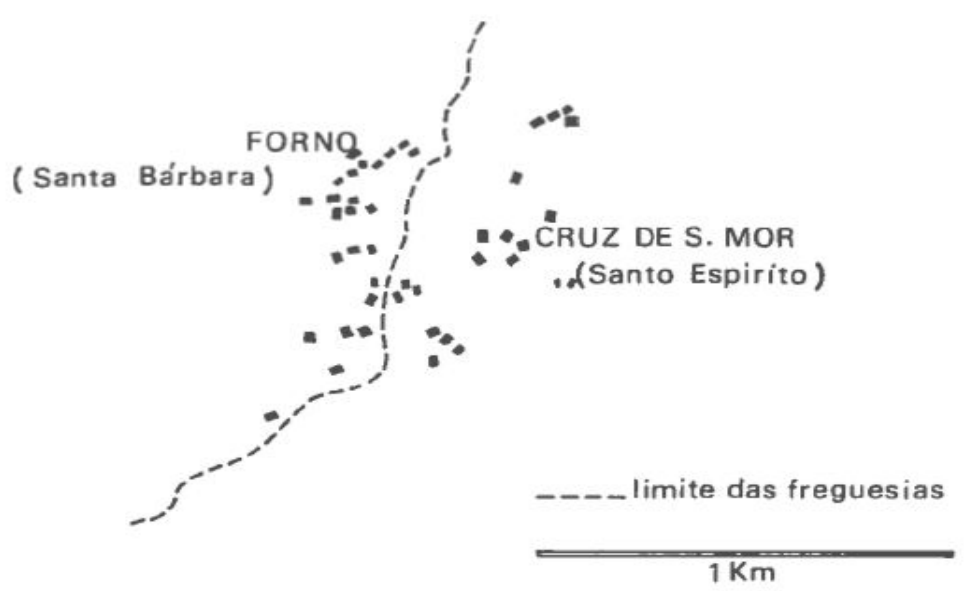

MAPA 2

Lugares do Forno e da Cruz de São Mor

Uma terceira modalidade menor do culto ao Espírito Santo é constituída pelos chamados Impérios secos. Tradicionalmente, realizavam-se em Santa Bárbara dois Impérios com estas características: um, por ocasião do São João (24 de Junho), e outro, por ocasião do São Pedro (29 de Junho).

Comecemos pelo Império de São João. A sua promoção não dependia, como no caso dos Impérios, de promessas individuais, mas assentava antes em formas de cooperação vicinal, envolvendo tradicionalmente o conjunto de moços solteiros da freguesia. Por essa razão, ele era também designado por Império dos rapazes. Estes, algum tempo antes do Império, reuniam entre si para escolherem quem devia desempenhar os principais cargos previstos na sua estrutura ritual: imperador, ajudantes grados, folia.

A sequência religiosa dos festejos era uma duplicação, de forma mais concentrada, da sequência religiosa dos Impérios e compreendia, além da coroação e dos vários cortejos previstos na estrutura usual dos Impérios, uma alumiação, realizada em geral na ante-véspera do dia de São João. Quanto às formas de circulação cerimonial do alimento, elas assentavam exclusivamente na distribuição generalizada, a seguir à missa da coroação, de massa sovada - pães da mesa e roscas - e vinho. A massa sovada resultava de ofertas feitas por casas da freguesia, com relevo para aquelas onde existiam moços solteiros. O vinho era comprado com o produto de um peditório realizado na freguesia poucos dias antes dos festejos.

O Império de São Pedro resultava por seu turno da cooperação entre o lugar do Forno - situado na periferia da freguesia - e o lugar da Cruz de São Mor - pertencente à vizinha freguesia de Santo Espírito (cf. mapa 2). 
Os festejos realizavam-se alternadamente em cada um dos lugares, que designavam também, de entre os respectivos vizinhos, os titulares dos diferentes cargos previstos na estrutura dos festejos: imperador, ajudantes grados e folia. Embora estes cargos fossem exercidos por adultos, a coroação incidia não sobre o imperador, mas sobre uma criança. A sua estrutura ritual era em linhas gerais similar à do Império de São João, sendo as distribuições generalizadas de massa sovada e de vinho asseguradas a partir de ofertas feitas pela totalidade das casas de ambos os lugares.

Devido sobretudo à crise demográfica provocada pela emigração nos lugares do Forno e da Cruz de São Mor, o Império de São Pedro deixou de se realizar há cerca de 20 anos.

O Império de São João esteve também durante um largo período de tempo sem se realizar. Entretanto, em 1986, devido a uma iniciativa do pároco local - na altura recém nomeado para a freguesia - foi recuperado, embora em moldes algo diferentes dos originais, sobretudo no tocante às suas formas de organização ${ }^{1}$. Esta passou a assentar em modalidades de cooperação que envolvem idealmente o conjunto da freguesia: é por intermédio de um sorteio aberto a todos os vizinhos que são escolhidos o imperador e os ajudantes grados e é a totalidade das casas da freguesia que é suposta fornecer os pães de mesa e roscas necessários aos festejos. Quanto à coroação, ela incide sobre uma criança, escolhida geralmente entre os filhos do imperador.

\footnotetext{
${ }^{1}$ Para uma análise mais detalhada das circunstâncias que rodearam o relançamento do Império de São João, cf. o Apêndice A deste livro.
} 
CAPítulo 3

A PARTE dos DEUSES 
Santa Bárbara é uma freguesia caracterizada por uma religiosidade muito forte.

Esse facto pode começar por ser surpreendido nos elevados índices de prática religiosa que a freguesia apresenta. De acordo com dados de 1979 a assistência dominical à missa envolvia cerca de $80 \%$ da população da freguesia, sendo de 34\% o número médio de comunhões regulares. Em 1983, apenas dez pessoas em toda a freguesia se eximiram à «desobriga pascal». E também importante a contribuição que as casas da freguesia dão às várias estruturas de carácter formal ou informal em que assenta a acção da igreja. Entre estas destacam-se, para além da Comissão Administrativa da paróquia e da catequese, a irmandade das Almas e a irmandade do Sagrado Coração de Jesus. A primeira tem como objectivo fundamental assegurar um certo número de missas de sufrágio pelas almas dos irmãos já falecidos. A segunda visa promover formas de devoção em relação ao Sagrado Coração de Jesus, cuja festa - celebrada no primeiro domingo de Agosto - constitui a festa «patronal» da freguesia. Uma outra organização religiosa importante é a Associação da Sagrada Família, baseada na circulação domiciliária de uma imagem da Sagrada Família. Durante o período que essa imagem permanece em cada uma das casas, os membros desta, além de procederem à entrega de esmolas, devem também rezar diariamente o terço.

Simultaneamente a estas modalidades institucionais, desenvolve-se um conjunto de outras formas de religiosidade de características mais independentes, ligadas a celebrações cíclicas, a devoções pessoais aos santos ou à Virgem, a práticas e crenças relacionadas com a morte, etc... Nestas várias formas de religiosidade, um motivo é particularmente importante: a promessa

${ }^{1}$ Dados do «Recenseamento feito nas Missas Dominicais de 6/2/77», publicados no número 72, de Abril de 1979, do Boletim Inter-Paroquial de ilha de Santa Maria «Renovar». 
como instrumento regular e privilegiado de relação com Deus. É por seu intermédio que cada indivíduo e cada casa tenta resolver muitos dos pequenos e grandes problemas com que se defronta. Entre estas formas mais independentes de religiosidade e aquelas que assumem uma expressão mais institucional não existe, entretanto, do ponto de vista da comunidade, solução de continuidade: geridas pela igreja ou autónomas em relação a ela, ambas fornecem vias de aproximação igualmente legítimas à divindade.

É justamente no quadro desta concepção geral do mundo e da vida em que a relação com Deus é vista como estreitamente associada aos destinos humanos que os Impérios devem começar por ser interpretados.

Situados do lado do que se convencionou chamar a «religiosidade popular» ${ }^{1}$, os Impérios obedecem de facto a um conjunto de motivações de natureza religiosa. Por detrás deles, como sublinham as pessoas, é antes do mais a «fé no Espírito Santo» que se perfila.

Essas motivações religiosas são particularmente importantes no caso do imperador. Resultando de uma promessa, o Império funciona para ele como um dos termos do contrato celebrado com a divindade que intercambia a graça divina solicitada com a «performance» de um ritual em sua homenagem e louvor. Além desse valor específico, a realização do Império surge ainda associada, de forma mais difusa, à ideia de uma protecção futura para o imperador e para a sua unidade doméstica. Nesse contrato religioso, estabelecido em última instância com o Espírito Santo, o patrono da igreja ou ermida para a qual o Império foi prometido funciona - de acordo com um mecanismo recorrente da promessa no mundo católico (cf., por exemplo, Foster, 1963, Boissevain, 1977, Christian Jr., 1978, 192-197) - como uma espécie de intermediário entre o vovente e a divindade (cf. figura 3$)^{2}$.

Tal como em muitos outros casos, este «contrato» individual estabelecido com a divindade é considerado como sagrado: acredita-se que o seu não cum-

\footnotetext{
${ }^{1}$ A expressão «religiosidade popular», embora consagrada, é susceptível de um conjunto de reparos. Cf., a este respeito Isambert, 1982. Para uma análise detalhada da relação entre Festas do Espírito Santo, povo e clero veja-se o Apêndice A do presente livro.

2 Contrariamente a um dos argumentos desenvolvido por Foster e Boissevain nos seus textos, não existe em Santa Bárbara qualquer conexão entre este tipo de relacionamento com a divindade e relações de «patrocinato» na esfera laica. Deve ainda notar-se que esta utilização dos santos e da Virgem como mediadores entre o vovente e o Espírito Santo é, no quadro geral dos Açores, específica dos Impérios de Santa Maria. Nas restantes ilhas do arquipélago — cf. Capítulo 8 - a relação é estabelecida directamente com o Espírito Santo.
} 
A PARTE DOS DEUSES

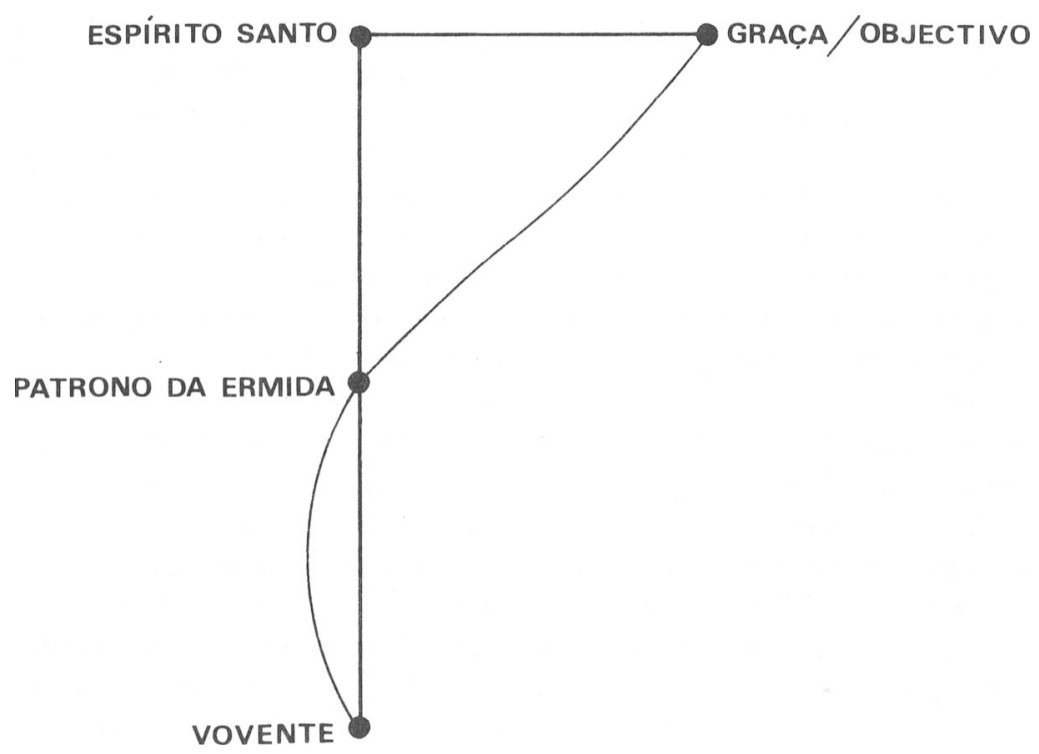

FIGURA 3

O mecanismo da promessa nos impérios

(Adaptado de Boissevain, 1977: 93)

primento - ou o seu deficiente cumprimento - em vida do vovente, faz com que, após a morte, a sua alma não encontre descanso enquanto a promessa não fôr satisfeita. Em muitos casos, o defunto surge em sonhos a um dos familiares, solicitando a realização, em seu nome, do Império. O encargo deste é geralmente assumido pelos seus parentes próximos - cônjuge sobrevivente, filhos, etc... - , dando lugar aos chamados Impérios de herdeiros ou Impérios de defuntos. Um dos Impérios que teve lugar na freguesia em 1982 resultou justamente de uma promessa não cumprida em vida pelo vovente. O encargo foi assumido pela viúva e pelos filhos que, além de terem repartido entre si os desempenhos principais - imperador, imperatriz, trinchante e mestre sala - contribuíram em partes iguais para as despesas dos festejos. Posteriormente à minha estada na freguesia, em 1988, voltaram a ter lugar dois outros Impérios de defuntos. Um deles foi realizado pelos dois filhos do vovente e, no outro, foram a viúva e os filhos - a maior parte dos quais emigrados - que asseguraram essa responsabilidade.

Ao assumir o encargo de promotor principal dos festejos, o imperador, ao mesmo tempo que satisfaz uma promessa individual, fornece também o contexto ritual para que a comunidade manifeste a sua devoção ao Espírito Santo. Essa devoção expressa-se, em primeiro lugar, por intermédio de um 
conjunto de outras promessas menores pagas no quadro dos Impérios. É o que se passa com um certo número de irmandades - tanto em pães de mesa ou roscas, como em dinheiro e em cabeças de gado - cuja oferta resulta de uma promessa ao Espírito Santo. Esta tanto pode ser pontual, como assumir, em certos casos, características mais permanentes. Há, por exemplo, pessoas que prometem fazer a oferta, todos os anos e «enquanto puderem», de um pão de mesa a pelo menos um Império da freguesia.

Simultaneamente a estas formas mais precisas de devoção, os Impérios são sobretudo encarados, pelo conjunto da comunidade, como um dos principais garantes do seu bem-estar colectivo.

Esta relação entre o culto do Espírito Santo e o bem estar colectivo é recorrente no conjunto dos Açores e possui uma das suas expressões mais conhecidas no vínculo existente entre as Festas do Espírito Santo e as crises de vulcanismo que assolam periodicamente algumas ilhas do arquipélago, com destaque para São Miguel, Terceira, Faial, Pico e São Jorge ${ }^{1}$. Esse vínculo reflecte-se, em primeiro lugar, num conjunto de tradições e conceptualizações populares que, ainda hoje, acompanham as Festas do Espírito Santo. Entre elas merece relevo especial a oração «Ó Senhor Espírito Santo» usada designadamente no quadro das Festas do Espírito Santo do Pico e do Faial e marcada por pedidos de protecção em relação a tremores de terra dirigidos ao Espírito Santo ${ }^{2}$.

Desta ligação entre o culto do Espírito Santo e o vulcanismo fazem-se também eco alguns relatos históricos sobre essas crises vulcânicas. Assim, nos terramotos e erupções vulcânicas que atingiram em 1672 a ilha do Faial, a Câmara da Horta, «tendo já antes promovido preces públicas e outros actos de piedade e devoção», deliberou colocar-se sob «a especial protecção do Divino Espírito Santo», renovando a sua irmandade então decaída e fez «o solene voto por si e seus descendentes, de todos os anos celebrarem uma missa solene com sermão e procissão em acção de graças no dia de Pentecostes, e de distribuírem pelos pobres uma parte dos seus frutos, se passassem os efeitos destruidores do vulcão» (Macedo, 1871: 184-185). Mais tarde, em 1760, perante novo terramoto, a população, depois de ter centrado as suas preces na imagem do Santo Cristo da Praia de Almoxarife, «lembrou-se então de

\footnotetext{
${ }^{1}$ Um sumário dos principais terramotos e erupções vulcânicas ocorridos nos Açores entre o início do povoamento e os finais do séc. XIX pode encontrar-se em Vargas e Machado, s/d.

${ }^{2}$ Veja-se a nota da p. 226 do Capítulo 10 para a variante desta oração usada nas Festas do Espírito Santo da freguesia de Nossa Senhora da Piedade (Pico). No Faial, partes desta oração são utilizadas no quadro da recitação formal de romances populares de temática absolutamente distinta, como «São José e a Virgem a Caminho das Montanhas». Veja-se a este propósito Fontes, 1980, pp. XLIX e 163-165. Esta contaminação entre o romanceiro popular açoriano e as Festas do Espírito Santo é corrente. Nas Flores, por exemplo, uma das alvoradas cantada pela folia no quadro das Festas do Espírito Santo é «O Lavrador da Arada», recitado como romance popular noutras ilhas.
} 
recorrer (...) ao Divino Espírito Santo (...). No dia 5 de Janeiro juntaram-se os irmãos da Santa Casa e oficiais da Câmara para que a Coroa se expusesse à devoção do Povo, junto à imagem de Cristo» e fosse festejada «sete domingos seguidos» (id., ibid.: 493), com procissões e coroações. No mesmo ano e ainda no início de 1761, a Terceira foi também assolada com vários terramotos e erupções vulcânicas que motivaram igualmente a realização de «procissões e muitas súplicas, sendo as mais consideráveis com as Coroas do Divino Espírito Santo» (Drummond, 1981: 289). Um dos Impérios mais conhecidos da Terceira - o Império de São Carlos - teve justamente a sua origem na ocasião: «diz a tradição que ali ergueram (...) um estrado de madeira sobre o qual foi colocado uma Coroa do Divino Espírito Santo. Reuniu-se à volta muito povo para implorar a protecção divina não tendo o denso fumo ultrapassado aquele sítio, apesar de ter durado três semanas, o que foi tomado por um milagre» (Lopes, 1980a: 216-217). O terramoto - acompanhado de erupções vulcânicas - que atingiu o Pico em 1719 originou também votos e preces ao Espírito Santo. «O povo de São Mateus (...) levou em procissão a coroa com a imagem do seu padroeiro para cima de um monte: e daí, que se avistava o fogo, fizeram voto de distribuirem pelos pobres esmolas em honra do Espírito Santo, no dia do orago do santo da sua freguesia, se o fogo cessasse» (Almeida, Gabriel de, 1889: 41). Paralelamente a este voto, ocorreu também na mesma ocasião um milagre do Espírito Santo: «entre tão lamentáveis ruínas não padeceram lesão (...) algumas casas de moradores que nelas tinham trigo e vinho dedicado e separado para gastarem no ano seguinte com os pobres no dia do Bodo do Divino Espírito Santo» (Rey, 1881: 291). Milagres similares são também relatados a propósito dos terramotos e erupção vulcânica de 1808 em São Jorge, no decurso dos quais a povoação da Urzelina foi inteiramente soterrada. Assim, em Santo Amaro, «indo a esta freguesia algumas procissões com o Espírito Santo e com as suas varas, e metendo estas na terra o fogo não passou além delas e por ali parou» (Cunha, P. ${ }^{\mathrm{e}}$ Manuel, 1981: 557). Na mesma ocasião «contou-se por milagre visível que uma pequena casa com seu reduto onde estava o vinho do bodo que ali se costumava dar em dia de Pentecostes, ficara ilesa correndo a lava ao redor» (Drummond, 1981, III vol.: 184). Segundo um outro autor, escapou também ao fogo «como pequeno oásis, um triângulo do primitivo terreno, em que estava uma rez destinada às esmolas do bodo do Divino Espírito Santo e a qual sobreviveu ao cataclismo» (Lopes, 1980a: 244) ${ }^{1}$. Em Santa Bárbara, ao mesmo tempo que

${ }^{1}$ A partir destes relatos generalizou-se em certos autores a tendência para explicar a força do culto do Espírito Santo nos Açores como resposta às características vulcânicas do arquipélago. Utilizada como um dos traços definidores da «açorianidade» (cf. em particular Ribeiro, Luís Silva, 1983), esta associação não é entretanto geral. Por outro lado, uma leitura atenta dos principais relatos de terramotos e erupções vulcânicas ocorridos nos Açores mostra que, a par da invocação do Espírito Santo, são feitas outras invocações. Cf. a este respeito Monteiro, Jacinto, 1983 
é possível reencontrar esta ligação entre o culto do Espírito Santo e ideias de bem-estar colectivo, ela recebe entretanto - dado inclusivamente o facto de Santa Maria ser uma das ilhas açorianas tradicionalmente poupadas ao vulcanismo - uma expressão mais genérica. Os Impérios são sobretudo vistos como uma espécie de garante difuso da «ordem das coisas». Os termos mais lapidares com que esta concepção me foi alguma vez apresentada foram os seguintes: «os Impérios nunca hão-de acabar; quando eles acabarem é porque o mundo chegou ao fim». Sob esta ou outras formas, os Impérios são pois vistos como algo que faz parte da respiração do mundo, que se integra na ordem esperada das coisas, tanto quanto a ratifica. Simultaneamente a esta concepção mais geral, os Impérios eram também encarados - em particular no quadro dos peditórios de géneros - como um garante da prosperidade agrícola, e, em particular, da protecção das colheitas ${ }^{1}$.

\section{II}

De acordo com as motivações que presidem à sua realização, os Impérios começam por se articular com um conjunto de cerimónias de natureza mais estritamente religiosa, entre as quais avultam as alumiações, a coroação e os vários cortejos que integram a estrutura ritual dos festejos. Mas é também de acordo com pressupostos similares que pode ser analisada a sua articulação com o conjunto de refeições, dádivas e distribuições de alimentos que passámos em revista.

Estas formas de circulação cerimonial do alimento assentam, como vimos, na dissipação de um avultado conjunto de riquezas. Para o imperador, na sua qualidade de financiador principal do Império, essa dissipação de riqueza constitui - no quadro das responsabilidades mais gerais que ele assume como patrocinador principal dos festejos - o instrumento principal de retribuição da graça divina solicitada. Gastos em honra da divindade, os alimentos que o imperador financia podem ser considerados como uma espécie de contra-dádiva à dádiva divina solicitada. A natureza dessa contra-dádiva assume contornos particularmente explícitos nos casos em que as promessas de que resultam os Impérios têm como motivo base a riqueza: obtida com o auxílio da divindade, uma parte dessa riqueza é-lhe depois oferecida em sinal de agradecimento. Certas promessas ilustram de forma particularmente clara este

'Nas «Memórias de Minha Ilha», Jacinto Monteiro (1982: 46) refere também um caso de utilização da Coroa do Espírito Santo como meio de debelar ataques de epilepsia. Esta atribuição à Coroa de propriedades curativas parece ser entretanto um caso isolado. Em Santa Bárbara, pelo menos, não encontrei referências a esse respeito. 
mecanismo. Assim, antes do surto emigratorio, eram correntes promessas relacionadas com a riqueza feitas nos seguintes termos: «se eu chegar a ter dez vacas da minha banda (ou vinte...), prometo gastar num Imperio em louvor do Espirito Santo, duas (ou três...) dessas vacas». Um dos Impérios realizados em 1986 teve na origem uma promessa desse tipo: o vovente - um lavrador abastado da freguesia - havia prometido um Império "caso chegasse a ter cinquenta vacas». Mais recentemente, houve também um Jantar, igualmente promovido por um lavrador local, resultante de uma promessa similar.

O relevo desta componente dos festejos expressa-se ainda no facto de muitas promessas envolverem a fixação do volume mínimo de gastos a realizar. E de facto frequente que, no acto de prometer um Império, o vovente especifique, por exemplo, o número de cabeças de gado ou as quantidades de vinho e trigo que se propõe gastar em dia de Império. E justamente de promessas desse tipo que derivam os Impérios em que é abatida uma junta de bois. Os Jantares e as Esmolas dão também lugar a procedimentos similares.

Encarada como o instrumento principal de retribuição da graça divina solicitada, a despesa requerida pelas formas de circulação cerimonial do alimento pode também tornar-se - caso o vovente não respeite os termos da sua própria promessa - num dos motivos principais da não aceitação do Império. $\mathrm{Na}$ freguesia são usualmente referidos dois desses casos. Um deles sucedeu há cerca de 40 anos e resultou de uma sugestão feita pelo pároco a um emigrante para que utilizasse o dinheiro que tencionava gastar no Império na compra de um crucifixo para o altar-mor da igreja paroquial. Essa sugestão foi aceite, mas depois da morte do vovente, os seus filhos, tendo sido confrontados com vários fenómenos estranhos — incorruptibilidade do cadáver vários anos após a morte, aparições do defunto —, interpretaram-nos como sinal da não aceitação da mudança de promessa e tomaram sobre si o encargo de promover o Império, "gastando o dinheiro para o que ele havia sido prometido». Um outro caso é mais recente e diz respeito a um Jantar, para o qual o vovente havia prometido uma junta de bois, e uma quantidade especificada de trigo e de vinho. Por razões que não me foram detalhadamente explicadas, o trigo e o vinho efectivamente dispendidos ficaram entretanto abaixo do prometido. Quando da realização do Jantar surgiram logo sinais de que qualquer coisa não estava bem: «a carne não cozia, os ajudantes não se entendiam». Mas, mais uma vez, foi após a morte do vovente que se tornou claro que a promessa não tinha sido aceite: surgiram desavenças entre a família, um dos filhos «entrava-lhe o defunto, pedindo para ele repetir a promessa». Em resultado, o Jantar veio a ser efectivamente repetido: além de uma nova junta de bois, houve mesmo o cuidado de gastar quantidades de trigo e de vinho superiores às inicialmente prometidas..

Simultaneamente ao dispêndio cerimonial do imperador, os Impérios envolvem também, como vimos, a contribuição da comunidade, seja por intermédio da sua participação nos peditórios de géneros, seja sobretudo por inter- 
médio da irmandade. Estas ofertas - que reproduzem numa escala ampliada ao conjunto da comunidade a atitude de dissipação da riqueza do imperador - começam também por possuir um importante significado religioso. Nos casos em que resultam de promessas, elas podem ser interpretadas à luz de pressupostos idênticos àqueles que presidem ao dispêndio cerimonial do imperador: de uma forma mais modesta, elas operam também como uma contradáviva à dádiva divina recebida. Quanto às restantes ofertas, é sobre elas que repousa em grande medida a vinculação dos Impérios a ideias de bem-estar colectivo. Esta concepção afirmava-se de forma particularmente clara em torno dos peditórios realizados por ocasião das debulhas, das vindimas e da apanha do milho, ligados, como vimos, a ideias de protecção das colheitas. Após a recepção da oferta, o imperador era solicitado a colocar o ceptro sobre os géneros pertencentes ao dono da casa e era a esse gesto - que retribuía a oferta realizada - que eram atribuídos poderes de protecção em relação às colheitas respectivas.

Esta concepção que faz da dissipação de riqueza, sob a forma de alimentos, o meio preferencial de comunicação com a divindade, embora tenha a sua expressão mais consistente e expressiva no quadro do culto ao Espírito Santo é uma tendência geral que se reencontra noutras práticas religiosas da freguesia.

A grande maioria das promessas exteriores ao culto do Espírito Santo são de facto feitas em termos idênticos, sob a forma da oferta de géneros ou mesmo alimentos, que são depois leiloados a favor da igreja. A festa de Santa Bárbara, que se realiza no primeiro domingo de Dezembro, consta fundamentalmente de leilões desse tipo, que se reencontram ainda na festa do Sagrado Coração de Jesus. Ao longo do ano, aos domingos, a seguir ao fim da missa, realizam-se também com alguma frequência leilões idênticos. Os géneros oferecidos são muito variados e vão desde animais - galinhas, porcos, vitelas ou gueixas, etc... — até ovos, enchidos de porco, produtos agrícolas, etc...

Gastos de acordo com pressupostos religiosos, os alimentos começam por circular nos Impérios também de acordo com pressupostos da mesma natureza. A sua distribuição e consumo são consideradas antes de mais uma forma de homenagear e louvar a divindade, como o salientam as inúmeras fórmulas de características religiosas que rodeiam as diferentes prestações. No quadro das distribuições porta-a-porta de alimentos previstas na estrutura ritual dos Impérios, os ajudantes que a asseguram fazem-se geralmente anunciar, em cada uma das casas que visitam, pela fórmula «Espírito Santo nesta casa». E também usual que a aceitação e agradecimento da generalidade dos alimentos seja feita com referência ao Espírito Santo: «seja em louvor do Espírito 
Santo» ou «o Espírito Santo lhe há-de dar o pago» são as fórmulas mais correntemente usadas com esse objectivo.

Alguns dos critérios que presidem à própria circulação do alimento possuem também características religiosas, assentes nos valores da caridade. Como vimos, é frequente a inclusão de casas mais pobres entre os destinatários de algumas das distribuições alimentares - seja no quadro das distribuições porta-a-porta de Sopas do Espirito Santo, seja no quadro da irmandade. E são também preocupações da mesma ordem que se encontram na base dos critérios adoptados para a distribuição de Esmolas. 
CAPÍTULO 4

A PARTE DOS HOMENS I 
Idealmente destinadas à divindade, as dádivas alimentares dos Impérios circulam efectivamente entre os homens. Começando por ligar os homens à divindade, elas ligam também entre si os homens.

Mauss, ao debruçar-se no célebre «Essai sur le Don» (1983a) sobre um conjunto de complexos sistemas de troca característicos das sociedades tradicionais, chamou a atenção para esta imbricação das vertentes religiosa e sociológica da dádiva. Essa chamada de atenção está desde logo contida na própria definição da dádiva como um fenómeno social total. E é depois objecto, ao longo do texto, de um tratamento mais detalhado. A secção IV do primeiro capítulo - intitulada «Le Présent fait aux Dieux, Le Présent fait aux Hommes» - é justamente consagrada à análise da dimensão propriamente religiosa da dádiva. Tomando como referência o potlatch, Mauss sublinha o modo como as trocas de presentes que nele intervêm são vistas como um meio de influenciar a disposição dos deuses em relação aos homens. «Um dos primeiros grupos de seres - sublinha Mauss - com os quais os homens tiveram de celebrar contratos, e que, por definição, existiam para celebrar contratos com eles, foram, antes do mais, os espíritos dos mortos e os deuses. Com efeito, são eles os verdadeiros proprietários das coisas e dos bens do mundo. Era com eles que era mais necessário trocar e mais perigoso não trocar. Mas, inversamente, era com eles que era mais fácil e mais seguro trocar» (Mauss, 1983a: 167). Simultaneamente, Mauss insiste sobre as virtualidades sociológicas da dádiva - esse é aliás, como se sabe, um dos aspectos mais retidos da sua conceptualização (cf. em particular Levi-Strauss, 1971: 61-79). Intervindo num quadro social profano, a dádiva é essa força «simultaneamente mística e prática que une os clãs e, ao mesmo tempo, os divide» (Mauss, 1983a: 268), é um símbolo da vida social que «mais não faz do que traduzir, muito directamente, a maneira como os sub-grupos destas sociedades segmentadas, de tipo arcaico, estão, permanentemente, imbricados uns nos outros» (id. ibid.: 194). 
É justamente esta dupla componente da dádiva que podemos reencontrar nos Impérios. Inscrevendo-se num domínio que começa por relacionar o indivíduo e a comunidade com a divindade, a circulação cerimonial do alimento encontra-se também neles ao serviço de um discurso centrado sobre as relações sociais.

Esse discurso começa por dizer respeito àquelas que são, em Santa Bárbara, as esferas onde o relacionamento social é mais intenso: o parentesco e a vizinhança de perto.

Vimos no Capítulo 1 que são duas as expressões principais que designam o grupo doméstico em Santa Bárbara: família e casa. A primeira aplicase ao grupo doméstico enquanto agregado de indivíduos unidos entre si por determinadas relações de parentesco. A segunda, por seu turno, designa o grupo doméstico na sua ligação a um espaço residencial próprio. É justamente a partir destas duas dimensões do grupo doméstico que se erguem esses dois eixos de relacionamento social. O parentesco insere cada família numa teia de relações baseada na consanguinidade e na aliança. A vizinhança de perto, por sua vez, inscreve cada casa num complexo de relações baseado na territorialidade.

Passemos em revista os aspectos principais de cada um destes círculos de sociabilidade. O parentesco, caracterizado por uma estrita bilateralidade, define para cada indivíduo ou grupo doméstico, o círculo onde os laços sociais possuem maior intensidade e proximidade.

São três as áreas principais em que se decompõe o mundo dos parentes. Uma primeira - a dos parentes chegados — é constituída pelas relações de parentesco de primeiro grau: pais, filhos e irmãos. Uma segunda abrange por seu turno as relações de parentesco de segundo grau, com destaque para os tios e primos filhos de irmão. Finalmente, uma terceira engloba os parentes desviados. À medida que se passa de uma para outra área o rendimento efectivo da linguagem do parentesco vai também decrescendo, até atingir na área dos parentes desviados - o mundo difuso dos primos segundos e terceiros, em relação aos quais a atitude predominante oscila entre o «ainda se liga» e o «é gente» - um rendimento praticamente nulo.

No interior da primeira área a intensidade e a proximidade sociais são pelo contrário máximas e exprimem-se em primeiro lugar por intermédio de um conjunto de modalidades informais de sociabilidade: inter-visitas, favores e serviços, assistência na doença e na velhice, etc... Simultaneamente, é nesta área que são mais frequentes a cooperação e a ajuda mútua, tanto sob a forma de trocas de mão como no quadro da formação de grupos de 
trabalho extensos. Finalmente, estes parentes desempenham um papel central nas ocasiões de maior relevo ritual de cada casa, em particular no quadro daqueles que são em Santa Bárbara os ritos de passagem mais importantes: o casamento e os ritos relacionados com a morte. O luto, em particular, é especialmente constrangente nesta área do parentesco, devendo prolongar-se por cerca de um ano. Embora possua um menor relevo cerimonial, o baptismo dá também lugar ao estabelecimento de laços especiais no interior deste grupo de parentes, uma vez que é entre os irmãos casados dos pais do recém-nascido que são preferencialmente escolhidos os seus padrinhos. Neste quadro geral que temos vindo a esboçar, deve ser feita uma referência especial à matação do porco. Comportando, paralelamente a uma vertente económica, uma importante vertente cerimonial, ela constitui de facto uma ocasião particularmente forte de reafirmação das relações sociais entre parentes chegados.

A particular intensidade que o relacionamento social adquire nesta área privilegiada do parentesco exprime-se ainda na manutenção de laços importantes nas condições criadas pela emigração. E entre estes parentes que são mais importantes e frequentes formas de contacto como a correspondência regular, o envio de «dolas» e presentes, etc... Um grande número de procurações são-lhes também confiadas. Por fim, é nesta área que é mais vincada a preocupação de inter-visita, com pretextos muitas vezes fornecidos por ocasiões de natureza cerimonial, com destaque para a realização de casamentos.

$\mathrm{Na}$ segunda área das relações de parentesco - constituída pelos parentes de segundo grau - o relacionamento social, embora apareça rodeado de algumas formas tradicionais de reconhecimento - expressas por exemplo no hábito de os sobrinhos, mesmo depois de casados, pedirem a benção aos tios - é já mais distendido, manifestando-se quase exclusivamente em ocasiões de natureza cerimonial, com destaque para os ritos de morte. Além de se integrarem no velório e no funeral, estes parentes devem ainda «guardar luto» durante um período de três meses. Entretanto, o facto de a emigração ter criado, em muitos grupos domésticos, um certo vazio ao nível das relações de parentesco de primeiro grau tem provocado uma certa revalorização, tanto subjectiva como prática, da importância destes parentes. Nesses casos, além de relações de cooperação e ajuda mútua mais frequentes, eles vêem-se também associados de forma mais importante à esfera do ritual.

Simultaneamente ao parentesco, é também importante o peso das relações baseadas na vizinhança de perto. Esta é composta pelas quatro ou cinco casas mais próximas de um dado grupo doméstico. Entre esses casas, aquela que está mais próxima é geralmente designada através da expressão vizinho do portal da porta. Dado o carácter disperso e irregular do povoamento, existe alguma margem de manobra na escolha concreta destes vizinhos. Mas, ape- 
sar deste carácter mais electivo, as modalidades de relacionamento social existentes entre vizinhos de perto aproximam-se bastante, na sua intensidade e importância, daquelas que existem entre o núcleo mais chegado de parentes. Um ditado recorrentemente citado na freguesia - «São Mateus/Primeiro os teus/Senão os vizinhos mais de perto» - põe justamente em evidência a homologia existente entre estes dois círculos sociais ${ }^{1}$.

$\mathrm{O}$ relacionamento entre vizinhos de perto começa também por reservar um importante papel a modalidades informais de sociabilidade: conversas, inter-visitas, empréstimo de objectos e alfaias, pequenos favores e serviços - como, por exemplo, a utilização comum de «frisas» (designação americanizada dada às arcas frigoríficas) - assistência na doença e velhice, etc... As formas de inter-ajuda entre vizinhos de perto asssumem igualmente uma certa importância, particularmente nas desfolhas do milho, que assentam sobretudo na cooperação vicinal. Finalmente, os vizinhos de perto têm também uma participação relevante na esfera do ritual, tanto no casamento como, sobretudo, nos ritos de morte, em que se substituem à unidade doméstica do morto no desempenho de certas tarefas de natureza prática ou ritual como a preparação do cadáver, a confecção de alimentos durante o período mais rigoroso do luto, etc... A matação do porco fornece também uma ocasião relevante para o reforço das relações entre vizinhos de perto. A importância destas relações expressa-se ainda na existência de rituais de saída ou de entrada na vizinhança, por ocasião de mudança de residência, envolvendo exclusivamente os vizinhos de perto. Os laços entre vizinhos de perto sobrevivem em muitos casos - particularmente se a relação se prolongou por muito tempo à emigração. Embora assumam uma expressão menos importante do que entre os parentes mais chegados, são frequentes casos de correspondência regular, de troca de presentes e favores - designadamente os que se resultam de procurações - entre ex-vizinhos de perto separados pela emigração. Ao mesmo tempo - de forma idêntica ao que sucede com as relações de parentesco de segundo grau - a emigração provocou também, entre as unidades domésticas privadas de relações de parentesco de primeiro grau, um aumento da importância relativa das relações de vizinhança de perto. Na ausência de parentes mais chegados na freguesia, é por exemplo frequente certos casais mais idosos solicitarem a um dos seus vizinhos de perto o encargo de os remir, isto é, de os assistirem na velhice, em troca da herança - assegurada geralmente por escritura notarial - da parte mais significativa dos seus bens.

\footnotetext{
${ }^{1}$ Esta importância da vizinhança de perto é também sublinhada, embora pela negativa, por dois outros ditados: «Nunca um invejoso medrou/ Nem quem ao pé dele morou» e «Antes um mau ano/ do que um mau vizinho». Em Cortes-Rodrigues é publicada uma versão ligeiramente diferente deste último ditado: «Antes um mau ano/ Do que um inimigo à porta» (1982: 97). Numa das conversas em que este ditado me foi citado, apressaram-se a explicar-me: «um mau ano sofrem-no todos, um mau vizinho sofre-o um sozinho».
} 
A importância deste complexo sociológico formado pelas relações de parentesco e vizinhança deve ser sublinhada. Surgindo em articulação com o predomínio, ao nível da organização doméstica, da família elementar, ela escapa ao tipo de correlações que têm sido estabelecidas entre formas de organização familiar e modalidades mais amplas de relacionamento social. Uma dessas correlações equaciona família elementar e fragilidade dos laços de parentesco. Assim, para Jorge Dias, enquanto que no norte do país, a predominância da família «extensa» seria acompanhada pela importância atribuída aos laços de parentesco, no sul, pelo contrário, o predomínio da família elementar seria dobrado pelo enfraquecimento daqueles: «a família é (...) a família elementar, sem outros laços de parentesco fortes» (Dias, A. Jorge, 1990a: 179; cf. também Dias, A. Jorge, 1990b: 187-191). Idêntica perspectiva reencontra-se em Cutileiro e na sua análise da estrutura social de Vila Velha: «não encontramos na freguesia um parentesco formal que se revista de direitos e deveres recíprocos e exclusivos. Fora da família elementar depressa se desvanecem as obrigações ditadas pelos laços de parentesco» (Cutileiro, 1971: 169). Em Santa Bárbara, pelo contrário, família elementar e laços de parentesco fortes não se apresentam como realidades mutuamente exclusivas. Num texto recente, por seu turno, João Pina Cabral, ao mesmo tempo que inverte os termos da equação família «extensa»/ laços de parentesco fortes vs. família elementar/ laços de parentesco fracos, estabelecida por Jorge Dias, procura correlacionar entre si formas de organização familiar e relações de vizinhança. Para este autor «nos sistemas (e complexos regionais) em que o princípio da casa é dominante, as relações entre vizinhos tendem a assumir um aspecto formal, enquanto que as relações entre parentes e compadres tendem a ser subalternizadas» (Pina Cabral, 1991: 238). Inversamente, «conforme o princípio da casa se vai subordinando ao princípio da conjugalidade, vamos encontrando sistemas em que as relações de parentesco se organizam em vicinalidades (frequentemente caracterizadas por uma orientação matrifocal). As relações de vizinhança não são formalizadas e tendem a confundir-se com as relações de amizade» (id., ibid.). Esta dupla asserção é negada pelo material de Santa Bárbara: dominada por aquilo que o autor designa de «princípio da conjugalidade», a organização familiar da freguesia coexiste com relações de vizinhança formalizadas que, por seu turno, não só são conceptualmente distintas das relações de parentesco como o ilustra o ditado que citámos atrás - como só raramente se organizam em «vicinalidades». Furtando-se ao tipo de correlações estabelecidas entre formas de organização familiar e modalidades mais amplas de relacionamento social, o material de Santa Bárbara sugere que o predomínio da família elementar não é forçosamente sinónimo do enfraquecimento - ora no eixo do parentesco, ora no eixo da vizinhança - do capital de relacionamento social de cada casa. 


\section{III}

As modalidades de sociabilidade entre parentes e vizinhos de perto que passámos atrás em revista concedem um papel extremamente importante à linguagem da dádiva alimentar. Esta opera, para retomar uma formulação de Sahlins, como «um barómetro delicado, uma espécie de declaração ritual das relações sociais (...) utilizada instrumentalmente como um mecanismo de início, de sustentação ou de destruição da sociabilidade» (Sahlins, 1978: 215). Esta vocação sociológica da linguagem da dádiva alimentar tem sido sublinhada, em contexto europeu, por vários autores. W. Douglass constatou a sua importância num estudo acerca dos ritos de morte na aldeia basca de Murelaga (Douglass, 1969). Stanley Brandes orientou a sua análise dos ritos de casamento numa aldeia castelhana na base de pressupostos idênticos (Brandes, 1973). Na monografia que consagrou à aldeia francesa de Minot, Françoise Zonabend reteve como uma das expressões mais relevantes da sociabilidade «aldeã», os circuitos de dádivas e contra-dádivas alimentares, de natureza muitas vezes informal, entre casas aparentadas ou vizinhas (Zonabend, 1976, em particular 78-96). Rolande Bonnain, ao escrever sobre a aldeia de Baronnies (Pirinéus franceses), pôs em destaque a importância atribuída a um conjunto amplo de ofertas alimentares e de refeições na configuração das relações de vizinhança (Bonnain, 1981a), chamando ainda a atenção para a importância dessas formas de reciprocidade no quadro da matança do porco (Bonnain, 1981b). Na sua monografia sobre Sainte-Engrâce - uma aldeia do país basco francês - Sandra Ott examinou de forma detalhada os sistemas de reciprocidade cerimonial entre vizinhos, associados à circulação de "pão bento» e ainda aos ritos de morte (Ott, 1981, 103-117; cf. também Ott, 1980). Finalmente, em Claude Macherel pode encontrar-se uma reflexão de natureza mais genérica sobre o fenómeno da dádiva nas sociedades rurais europeias (Macherel, 1983). O carácter isolado e recente destes estudos deve ser sublinhado. Apesar do «Essai sur le Don» conter, designadamente na sua parte final, algumas referências à importância da dádiva em contexto europeu (cf. Mauss, 1983a: 258-260), a antropologia europeia tem-se caracterizado por uma certa indiferença a essa dimensão das sociedades que constituem o objecto do seu estudo.

Em Santa Bárbara, a importância da linguagem da dádiva alimentar reencontra-se, em primeiro lugar, em associação estreita com as modalidades mais informais de sociabilidade entre parentes e vizinhos de perto que referimos atrás. As inter-visitas são muitas vezes secundadas por brindes - designação localmente dada a pequenas ofertas de bebidas ou alimentos de consumo instantâneo ${ }^{1}$ - refeições ou oferendas alimentares informais. Entre os peque-

\footnotetext{
${ }^{1}$ É provavelmente da palavra brinde - utilizada no sentido que acabámos de referir que provém a expressão brindeiro, usada para designar uma certa qualidade de pão de trigo temperado. Na freguesia utiliza-se também correntemente o verbo brindar como sinónimo de oferecer qualquer coisa a alguém.
} 
nos favores e serviços que têm lugar entre vizinhos de perto contam-se frequentes ofertas de géneros alimentares ou, inclusivamente, de alimentos cozinhados. Estão neste último caso as ofertas de brindeiros que muitas casas fazem, no dia em que cozem o pão, à vizinhança de perto. As formas de cooperação e ajuda mútua no quadro da actividade agrícola, em particular as que exigem a formação de grupos de trabalho mais extensos, articulam-se também com formas importantes de partilha alimentar e comensalidade. A casa para quem o trabalho está a ser executado, além de fornecer as refeições às pessoas que nele participam, deve ainda assegurar a realização regular de corridas de vinho no início e no termo de cada período de trabalho e, ainda, ao longo do dia.

Mas é sobretudo no quadro das ocasiões mais formais de relacionamento social que as virtualidades da linguagem da dádiva alimentar se revelam de forma mais expressiva. Entre essas ocasiões, conta-se a matação do porco, tradicionalmente associada a um conjunto amplo de refeições e prestações alimentares. Essas refeições e prestações alimentares começam por intervir no interior do grupo de trabalho que se constitui para o efeito, integrado por cerca de dez pessoas de ambos os sexos escolhidas entre as unidades domésticas que fazem parte da área dos parentes mais chegados da casa anfitriã ${ }^{1}$. No dia da matação a totalidade das refeições não apenas dos membros do grupo de trabalho, mas, em muitos casos, do conjunto de elementos que fazem parte das respectivas unidades domésticas são oferecidas pelos anfitriãos. Estas refeições são em geral refeições melhoradas e muito abundantes: além de biscoitos - com destaque para os chamados biscoitos da matação ${ }^{2}$ - e massa sovada, muitas casas matam ainda para o efeito uma ou duas galinhas. No dia seguinte - ocupado com a preparação dos enchidos - essas casas voltam a ser convidadas para uma nova refeição — geralmente a ceia - no decurso da qual são servidos alguns dos alimentos preparados com a carne do porco abatido na véspera, com destaque para os torresmos. No termo da refeição - comumente designada pela expressão provar os torresmos — essas casas recebem ainda uma oferta integrada por um pedaço de carne de porco crua e por um conjunto de alimentos representativos das principais preparações culinárias feitas a partir do porco: torresmos, morcelas, molhe ${ }^{3}$, etc... Começando por privilegiar as unidades domésticas envolvidas no grupo de trabalho da matação, a rede de dádivas alimentares com que esta se articula estende-se ainda a outras casas, entre as quais ocupam lugar de relevo outros

\footnotetext{
${ }^{1}$ Os dados relativos à matação do porco baseiam-se na assistência a cerca de dez matações, para as quais fui convidado no decurso das minhas estadas em Santa Bárbara, designadamente em Novembro e Dezembro de 1987.

${ }^{2}$ Este biscoito é também conhecido sob a designação de bolo talhado e é feito com uma massa similar à do biscoito de orelha, mas mais leve.

${ }^{3}$ Os torresmos são pedaços de carne de porco fritos em gordura de porco. O molhe é uma espécie de arroz de porco, confeccionado com restos de sangue.
} 
parentes de primeiro grau e os vizinhos de perto. Estas casas são convidadas, no primeiro dia da matação, para ir ver o porco, sendo na altura brindadas com biscoitos, massa sovada e vinho. São também geralmente convidadas para a refeição do dia seguinte, no termo da qual são ainda presenteadas com uma pequena oferenda alimentar, integrada por duas ou três morcelas.

Os ritos de passagem reservam também um lugar de relevo a um conjunto diversificado de refeições e prestações alimentares. Estas têm uma expressão particularmente importante no casamento ${ }^{1}$. Este envolve, em primeiro lugar, um conjunto de ofertas em géneros - ovos, farinha, trigo - feitas por parentes e vizinhos de perto a cada um dos noivos, nas duas semanas anteriores à data aprazada para a cerimónia. Estas ofertas são depois retribuídas, nas vésperas do casamento, através de uma distribuição porta-a-porta de brindeiros ou escaldadas.

Mas é sobretudo no quadro das cerimónias formais a que o casamento dá lugar que é importante o peso da linguagem da dádiva alimentar. Estas cerimónias estendem-se por dois dias: o dia dos noivos, que recai a um sábado e é o dia em que tem lugar a cerimónia religiosa do casamento e o domingo das visitas, que se realiza no domingo imediato e que é preenchido por um conjunto de visitas cerimoniais de parentes, vizinhos e amigos aos recém-casados. E no decurso destas visitas que os convidados à boda entregam aos noivos dos presentes de casamento ${ }^{2}$. Tradicionalmente estas visitas obedeciam a uma separação por sexos; as mulheres visitavam os noivos da parte da manhã e a tarde era reservada às visitas dos homens.

O dia dos noivos compreende, além da cerimónia religiosa, duas refeições. A primeira tem lugar antes da missa de casamento e realiza-se em casa dos pais do noivo. Trata-se de uma refeição ligeira, composta fundamentalmente por biscoitos, massas, bolos e doces ${ }^{3}$. A refeição da boda propriamente dita tem por sua vez lugar no termo da missa e realiza-se em casa dos pais da noiva. A sua ementa é particularmente rica e, além, mais uma vez, de uma grande variedade de biscoitos, massas, bolos e doces, consta ainda de dois ou três pratos de carne - galinha, vitela, etc... Além destas duas refeições, o casamento é ainda marcado por um conjunto de outras prestações alimentares. Entre elas merecem particular relevo um conjunto de ofertas alimentares destinadas aos vizinhos de perto. Estes, na véspera do dia dos noivos, são convidados por cada um dos noivos a ver a mesa armada para o dia seguinte, sendo brinda-

\footnotetext{
${ }^{1}$ Os dados relativos ao ritual do casamento assentam em recolhas conduzidas em dois casamentos realizados na freguesia em Agosto e Novembro de 1987.

${ }^{2}$ Esses presentes são também conhecidos pela designação de visitas. Esta expressão é ainda utilizada para designar qualquer oferta de valor afectivo e também como sinónimo de «cumprimentos»; nas cartas, a expressão «dá visitas a fulano» equivale a «manda cumprimentos meus a fulano».

${ }^{3}$ Nalguns casos e devido à influência da emigração, passaram a realizar-se duas refeições com estas características, uma em casa dos pais do noivo, abrangendo os convidados deste e outra em casa dos pais da noiva, destinada aos convidados desta.
} 
dos com massas e vinho. Caso os noivos passem a residir numa área diferente, estão também previstas prestações específicas tanto junto dos seus ex-vizinhos como dos seus novos vizinhos de perto. As primeiras têm lugar no próprio dia dos noivos e constam de um presente composto por cada uma das qualidades de alimentos servidos na refeição da boda. As segundas têm lugar no domingo das visitas e são geralmente integradas por massa sovada. Por fim, as visitas cerimoniais que se realizam no domingo das visitas têm também uma forte marcação alimentar. E preparada uma mesa com biscoitos, massas, bolos, doces e vinho, e à medida que as pessoas chegam, são convidadas a servir-se.

Os ritos de morte surgem igualmente associados a um conjunto importante de dádivas e contra-dádivas de natureza alimentar. Estas intervêm desde logo no velório, no decurso do qual as pessoas presentes são brindadas com biscoitos e vinho. Mas atingem a sua expressão mais significativa no quadro da Ceia dos Anojados. Esta Ceia tem lugar cerca de uma semana após a realização do enterro, no seguimento da chamada missa do vestido de alma. Esta missa recebe a designação da crença segundo a qual a alma do morto se deve apresentar diante de Deus com um vestido novo e de festa. Esse vestido ou fato - é comprado expressamente para o efeito e é envergado durante a missa por um parente próximo do morto, escolhido de acordo com a vontade deste. Muitas pessoas na freguesia consideram que se este ritual não for realizado, a alma do morto «não sobe ao céu». É justamente após o termo desta missa que se realiza a Ceia dos Anojados: trata-se de uma refeição melhorada, preparada pelos vizinhos de perto da unidade doméstica do falecido, na qual participam a totalidade dos parentes de primeiro grau deste. A sua realização marca o termo do período mais carregado de luto, assinalando a reintegração parcial destes parentes na vida social corrente.

O nascimento dá também lugar a um certo número de dádivas alimentares. Logo após o nascimento, a mãe do recém-nascido recebe algumas ofertas em géneros - ovos, açúcar, etc... - que lhe são feitas por parentes e vizinhas de perto. O baptismo é igualmente assinalado por uma pequena refeição que junta os pais da criança e os padrinhos.

A própria relação de apadrinhamento, por fim, possui também um importante conteúdo alimentar: ela é periodicamente sublinhada através da oferta ao afilhado, pelo Natal, de um biscoito de orelhal. Os ritos de casamento - que marcam o termo do período mais significativo da relação de apadrinhamento - articulam-se também com um conjunto significativo de prestações e contra prestações alimentares entre padrinhos e afilhados. Aqueles, antes do casamento, oferecem a cada um dos noivos um açafate de escaldadas e uma certa quantidade de vinho, como contribuição para as despesas da boda. No domingo das visitas, estas ofertas são por seu turno retribuídas pelos noivos que pre-

${ }^{1}$ Esta oferta substitui a oferta do folar pela Páscoa, forma tradicional de reafirmação da relação de apadrinhamento no contexto português e também nos Açores. 
senteiam cada um dos respectivos padrinhos, com um açafate contendo as diversas qualidades de biscoitos e massas servidos no decurso da boda.

Intimamente associada ao «regular» funcionamento das relações sociais nas esferas do parentesco e da vizinhança de perto, a linguagem da dádiva alimentar — com o seu misto de obrigação e gratuitidade — opera também como um verdadeiro aferidor do estado «real» dessas relações. O caso mais significativo é o da matação do porco e, em particular, dos convites para ver o porco. Do mesmo modo que a existência do convite e a sua aceitação e retribuição são encaradas como a expressão por excelência do «bom estado» dessas relações, a sua inexistência é associada a uma situação de degradação ou ruptura no relacionamento. É frequente que situações de fricção entre casas aparentadas ou vizinhas sejam comentadas nesses termos: «fulano e fulano não se dão, nem sequer se convidam para ir ver o porco...» Particularmente expressiva neste caso, essa faceta da linguagem da dádiva reencontra-se nas restantes situações que passámos em revista: a inexistência de uma visita no casamento de um parente chegado ou de um vizinho de perto, o «esquecimento» de retribuir uma oferta de brindeiros podem servir para marcar uma distância antiga ou uma ruptura recente.

De uma ou de outra forma o jogo das relações sociais em Santa Bárbara aparece estreitamente associado às virtualidades significantes da linguagem da dádiva - a essa tripla obrigação de dar, receber e retribuir de que falava Mauss - e o seu adequado manuseamento constitui sem dúvida um dos aspectos essenciais do «ethos» cultural prevalecente na freguesia.

\section{IV}

É neste quadro geral caracterizado pela estreita ligação da linguagem da dádiva alimentar a mecanismos de reafirmação, de criação ou de ruptura de determinados laços sociais que podem justamente ser interpretados os Impérios.

As diferentes refeições, dádivas e distribuições alimentares que integram a sua sequência ritual começam de facto por intervir neles como um instrumento de reafirmação das relações sociais entre o imperador e os seus parentes e vizinhos de perto ${ }^{l}$.

Esse vínculo entre a linguagem da dádiva alimentar e as relações sociais próximas de cada imperador estabelece-se em primeiro lugar por intermédio

\footnotetext{
1 Tal como no Capítulo 2, também neste e no próximo capítulo serão sobretudo utilizados referentes aos quatro Impérios realizados na freguesia em 1987. Entretanto, sempre que me pareceu necessário, recorri também a informação respeitante a Impérios que tiveram lugar em anos anteriores. A maior parte dessa informação foi recolhida no decurso das estadias realizadas em 1982 e 1983. Outra foi recolhida oralmente em várias sessões de trabalho com os copeiros da freguesia.
} 


\begin{tabular}{|c|c|c|}
\hline & a judantes & parentes \\
\hline Primeiro Império de Santa Bárbara & 8 & 3 \\
\hline Segundo Império de Santa Bárbara & 8 & $21 / 2$ \\
\hline Primeiro Império do Norte & 6 & 1 \\
\hline Segundo Império do Norte & 7 & $41 / 2$ \\
\hline
\end{tabular}

\section{QUADRO 12 \\ Ajudantes e parentes nos Impérios (Santa Bárbara, 1987)}

do grupo de ajudantes. Como tivemos ocasião de sublinhar, o grupo dos ajudantes constitui o quadro em que a circulação cerimonial do alimento é mais intensa. Para além de contra-prestações que visam explicitamente retribuir o seu trabalho - como a irmandade e, hoje em dia, o «envelope» final — é também entre os ajudantes que circula uma parte importante do dispêndio propriamente cerimonial do Império. Além dos direitos específicos que detêm no quadro das prestações mais ampliadas que integram a sequência ritual dos festejos, os ajudantes são ainda beneficiados com um conjunto de prestações que lhes são expressamente consagradas, com relevo para as Ceias de Ajudantes que assinalam o início e o termo do Império.

Ora os critérios que presidem à formação do grupo dos ajudantes têm como característica central a importância que concedem às esferas do parentesco e da vizinhança de perto de cada um dos imperadores.

$\mathrm{O}$ parentesco assume particular relevo, como se pode verificar pela proporção de parentes entre os ajudantes, situada, nos Impérios que se realizaram em 1987, entre 40 a $60 \%$ do total dos ajudantes (cf. quadro 12 e diagramas $1,2,3$ e 4). Se nos voltarmos para anos anteriores, encontramos números idênticos (cf. quadro 13).

\begin{tabular}{llc}
\hline & a ju d a n t e s & par en te s \\
\hline $1981(1)$ & 34 & 23 \\
$1981(2)$ & 37 & 20 \\
$1982(1)$ & 25 & 15 \\
$1982(2)$ & 24 & 12 \\
$1982(3)$ & 31 & 16 \\
$1982(4)$ & 34 & 16 \\
$1982(5)$ & - & 10 \\
$1983(1)$ & 32 & \\
\hline & QUADRO 13 &
\end{tabular}




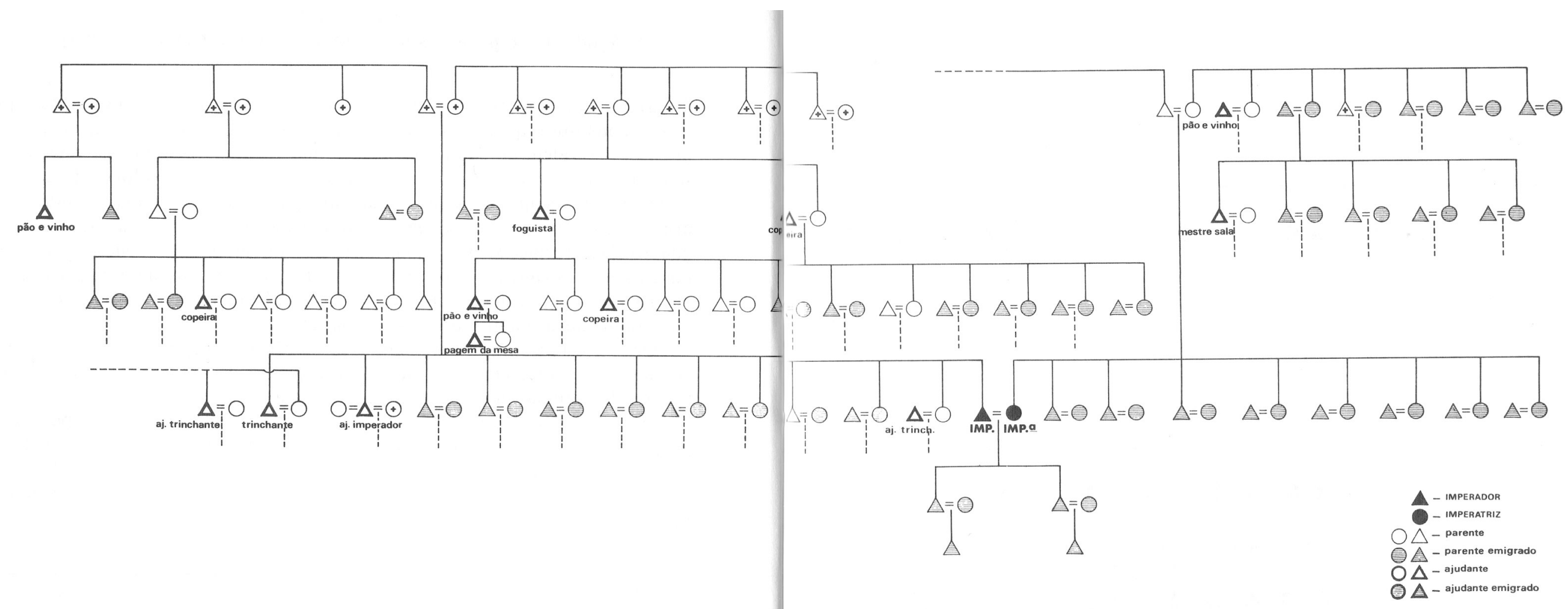

DIAGR 1

Ajudantes e parentes (Primeiro II mpério de Santa Bárbara, 1987) 


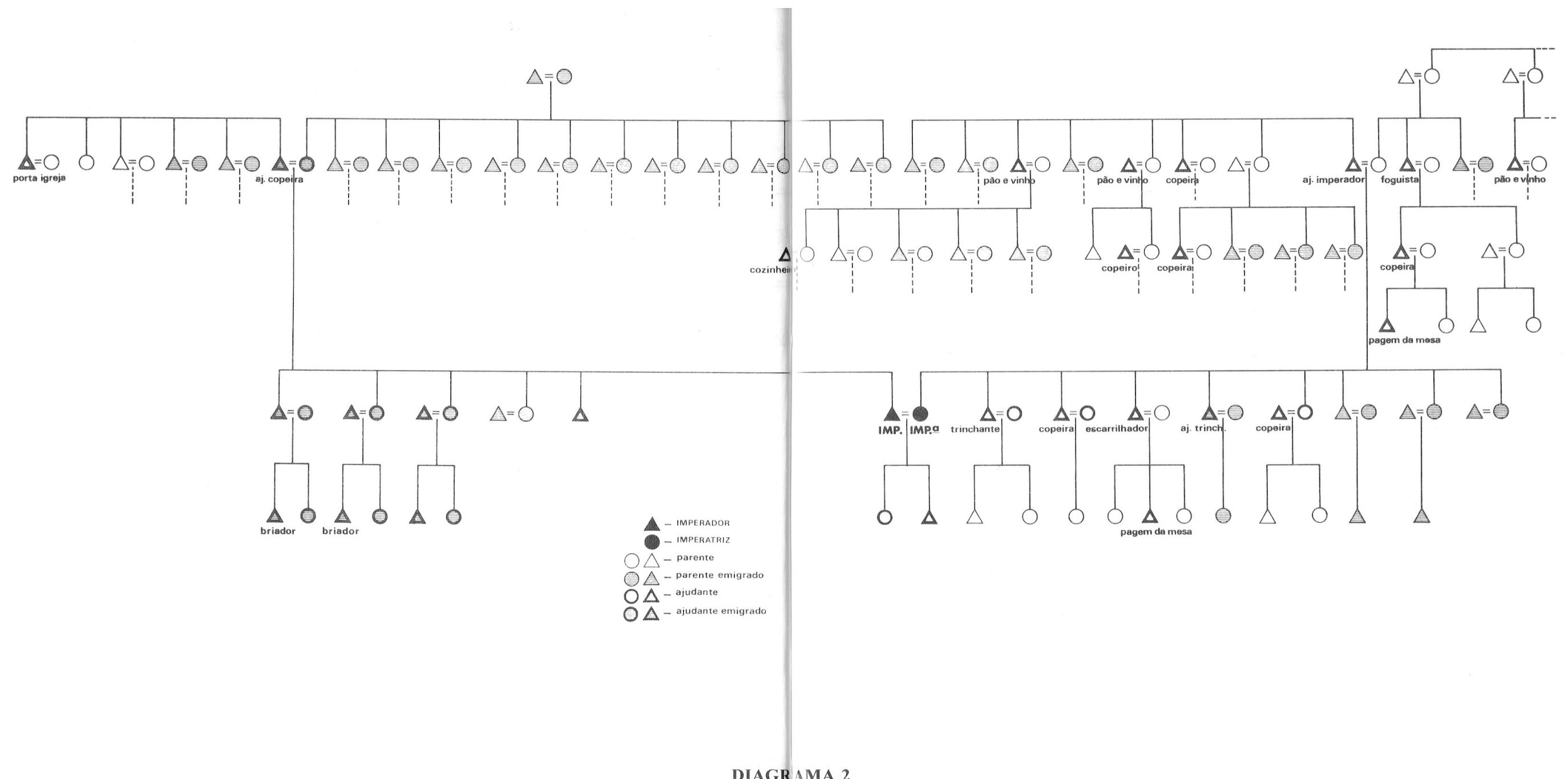

DIAGR AMA 2

Ajudantes e parentes (Segundo I mpério de Santa Bárbara, 1987) 


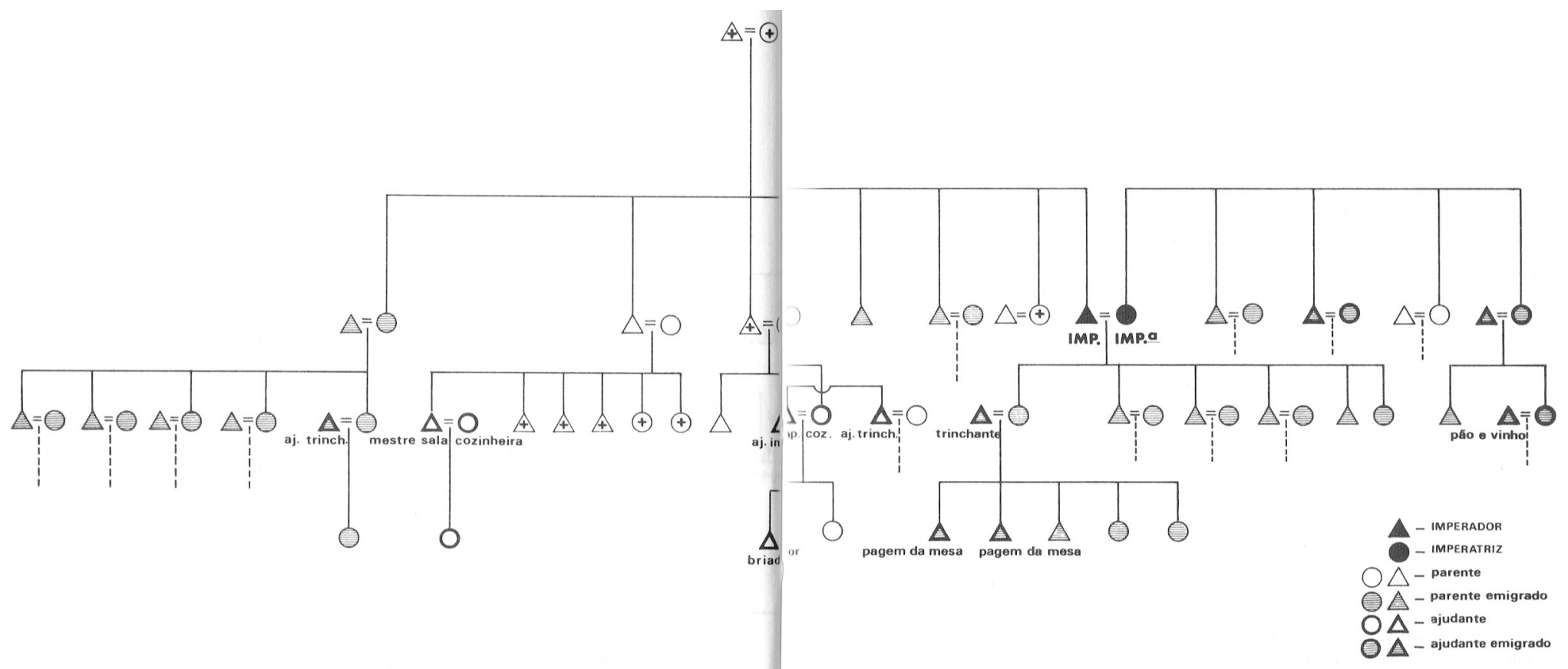

DIAGR AMA 3

Ajudantes e parentes (Prime iro Império do Norte, 1987) 


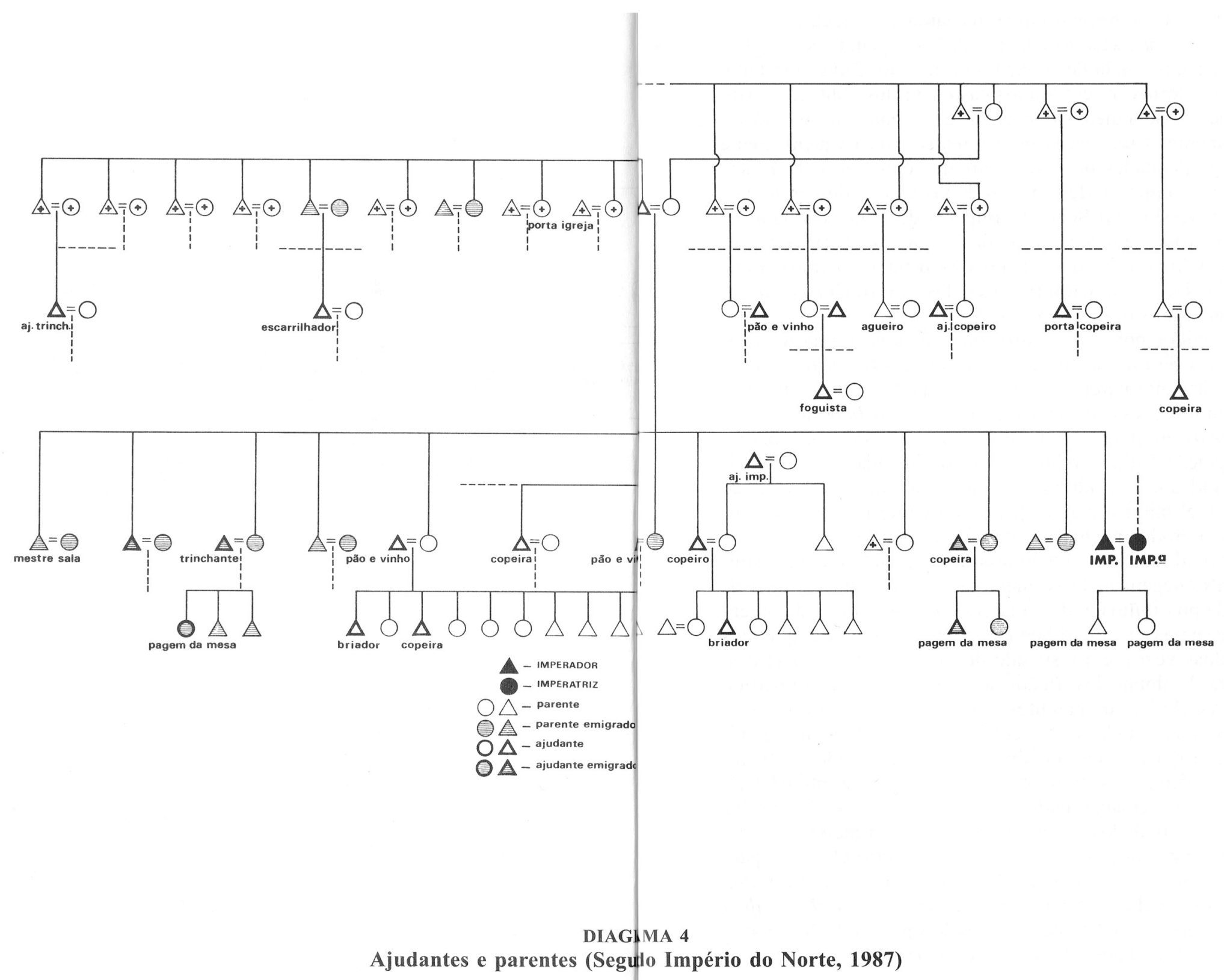

Ajudantes e parentes (Seguto Império do Norte, 1987) 
Esta mobilização das relações de parentesco faz-se de acordo com alguns dos princípios gerais que estruturam esta área fulcral do relacionamento social. A prioridade é dada às relações de parentesco de primeiro grau: pais, irmãos e, eventualmente, filhos casados do imperador e da imperatriz são de facto supostos associar-se em plano de relevo ao Império.

Essa participação abrange em primeiro lugar os parentes residentes na freguesia. São raros aqueles que não se associam ao Império. Quando isso sucede fica em geral a dever-se à existência de situações de fricção. Deve entretanto referir-se que os Impérios fornecem em muitos casos um dos contextos principais para reconciliações — pelo menos momentâneas — entre parentes desamanhados. Simultaneamente, a realização de um Império dá frequentemente origem a deslocações propositadas de vários parentes emigrados. Dois dos Impérios atrás indicados assumiram, deste ponto de vista, uma dimensão particularmente expressiva. Assim, no Segundo Império de Santa Bárbara, os pais e quatro dos cinco irmãos do imperador deslocaram-se expressamente para o Império, sucedendo o mesmo com um dos irmãos da imperatriz. No Segundo Império do Norte, por seu turno, três dos sete irmãos embarcados do imperador vieram também de propósito para o Império.

Nos Impérios promovidos por imperadores residentes na freguesia verifica-se a mesma tendência. Foi o que sucedeu com um dos Impérios realizados em 1981: do total de vinte parentes entre os ajudantes, oito eram emigrantes que se deslocaram expressamente à freguesia para o Império.

$\mathrm{O}$ facto de os Impérios propiciarem uma momentânea reunião dos parentes afastados pela emigração é aliás enfaticamente sublinhada. «Nunca mais nos voltamos a juntar todos», «é a última vez que a família se reúne», são comentários que é possível ouvir a esse respeito. Tal como nos casamentos, a ocasião é utilizada para produzir registos fotográficos e em vídeo que, uma vez terminado o Império, alimentarão a memória dessa grande reunião familiar. Muitos imperadores chegam inclusivamente a fazer depender a data da realização do Império da possibilidade de juntarem o maior número de parentes próximos. Foi o que se passou com o Segundo Império do Norte, que teve a sua data adiada por duas vezes, em resultado de impedimentos em se deslocarem a Santa Bárbara de alguns dos irmãos do imperador. Tirando partido desta concentração extraordinária de parentes, a realização de um Império é também frequentemente aproveitada para a celebração de outros ritos familiares. Foi o que sucedeu em três dos Impérios que temos vindo a utilizar como quadro central de análise. Assim, o Segundo Império de Santa Bárbara deu lugar à realização, duas semanas mais tarde, do casamento de um dos irmãos do imperador, os convidados do noivo eram mais ou menos os mesmos que os parentes e vizinhos de perto que o imperador tinha chamado para integrarem o grupo de ajudantes do Império. O Primeiro Império do Norte, por seu turno, foi antecedido pela realização de uma missa de vestido de alma de uma cunhada da imperatriz. Finalmente, o Segundo Império do Norte articulou-se com a celebração dos 50 anos de casado dos pais do imperador, mais 


\begin{tabular}{lcc}
\hline & AJUDANTES & $\begin{array}{c}\text { VIZINHOS } \\
\text { DE PERTO }\end{array}$ \\
\hline Primeiro Império de Santa Bárbara & 34 & 7 \\
Segundo Império de Santa Bárbara & 32 & 4 \\
Primeiro Império do Norte & 29 & - \\
Segundo Império do Norte & 33 & 2 \\
\hline
\end{tabular}

QUADRO 14

Ajudantes e vizinhos de perto nos Impérios (Santa Bárbara, 1987)

uma vez, notava-se uma flagrante coincidência entre os que tinham sido ajudantes do Império e os convidados para o aniversário.

É justamente no interior deste núcleo central de parentes que são idealmente distribuídos certos cargos mais importantes, com destaque para os assegurados pelos ajudantes grados. O trinchante e o mestre sala - assim como o ajudante de trinchante - são usualmente irmãos do imperador ou da imperatriz, com prioridade para aqueles que realizaram uma oferta vultuosa ao imperador. Os briadores são geralmente escolhidos entre os sobrinhos solteiros do imperador e/ou da imperatriz. Caso os filhos do casal não tenham a idade adequada para o exercício do cargo, é também entre os sobrinhos de um ou de outro que são escolhidos os pagens da mesa. Quanto aos pais do imperador e da imperatriz, é geralmente sobre um deles que recai o cargo de ajudante de imperador. Os restantes parentes de primeiro grau, por fim, distribuem-se de forma mais indiferenciada pelos restantes cargos.

Os critérios gerais que acabámos de passar em revista são particularmente claros no caso do Segundo Império de Santa Bárbara e no Segundo Império do Norte. No Segundo Império de Santa Bárbara, os briadores foram dois dos sobrinhos do imperador, sendo os cargos de ajudante do imperador, trinchante e ajudante de trinchante desempenhados respectivamente pelo pai e por dois irmãos da imperatriz; um dos pagens da mesa era também um sobrinho da imperatriz. No Segundo Império do Norte, por seu turno, os cargos de trinchante, mestre sala e briadores foram exercidos por dois irmãos e dois sobrinhos do imperador, que resolveu ainda acrescentar mais dois pagens da mesa ao número tradicionalmente previsto, por forma a, além dos seus próprios filhos, associar a esse desempenho dois dos seus sobrinhos. Devido à sua idade avançada, o pai do imperador, em vez do cargo de ajudante do imperador que exige, em dia de Império, o dispêndio de um certo esforço - foi convidado para ajudante da porta da igreja. Nos outros dois Impérios de 1987, embora de uma forma menos expressiva, esta tendência é também reencontrável. Assim, no Primeiro Império de Santa Bárbara, os cargos de trinchante, ajudante de trinchante e ajudante do imperador foram desempenhados res- 
pectivamente por dois irmãos e um cunhado do imperador, seus únicos parentes de primeiro grau residentes na freguesia. No Primeiro Império de Santa Bárbara os cargos de trinchante e pagens da mesa foram também confiados a parentes próximos: respectivamente um genro e dois netos do imperador.

Além dos parentes de primeiro grau, a formação do grupo de ajudantes envolve ainda o recurso a relações de parentesco de segundo grau. E de facto frequente a inclusão de tios ou primos filhos de irmão tanto do imperador como da imperariz no grupo de ajudantes. Nalguns casos, a constituição deste pode envolver inclusivamente a manipulação de relações de parentesco ainda mais afastadas, como sejam primos terceiros ou relações de afinidade de consanguíneos, tanto do imperador como da imperatriz.

De uma maneira geral, estes parentes fornecem cerca de metade do total de parentes incluídos no grupo dos ajudantes. E justamente esse o caso do Segundo Império de Santa Bárbara e ainda do Segundo Império do Norte.

Mas a sua participação pode subir para números superiores quando a um baixo número de parentes de primeiro grau residentes na freguesia se acrescenta uma menor participação de parentes emigrados no Império. Nesses casos, alguns dos cargos mais importantes que referimos anteriormente podem inclusivamente ser assegurados, em alternativa, por estes parentes. É justamente esse o caso dos dois outros Impérios de 1987. Assim, no Primeiro Império de Santa Bárbara, de um total de treze parentes que integravam o grupo de ajudantes, dez eram parentes em segundo ou terceiro grau do imperador e/ou da imperatriz. Foi justamente um desses parentes - um primo da imperatriz - que foi convidado para exercer o cargo de mestre sala. No Segundo Império do Norte, por seu turno, dos catorze parentes que faziam parte do grupo dos ajudantes, onze eram parentes em segundo ou terceiro grau do imperador e/ou da imperatriz, tendo sido entre eles que foram convidados o mestre sala, o ajudante de trinchante e o ajudante do imperador.

Simultaneamente ao parentesco, a formação do grupo de ajudantes privilegia também a linguagem da vizinhança de perto. Esta, mesmo nos casos de Impérios promovidos por emigrantes, mantém-se como um dos critérios básicos para a formação do grupo de ajudantes, conforme é possível verificar no quadro 14 e nos mapas 3,4 e 5$)^{1}$.

\footnotetext{
${ }^{1}$ No Segundo Império de Santa Bárbara, assim como no Segundo Império do Norte, a fase preliminar dos festejos decorreu em casa de parentes chegados dos imperadores - - a avó, num caso, os pais, noutro - e os vizinhos de perto que integraram o grupo dos ajudantes foram escolhidos entre as casas que mantinham usualmente uma relação de vizinhança com as casas desses parentes. Quanto aos dois outros Impérios, a sua fase preliminar decorreu na casa dos próprios imperadores e a definição da vizinhança de perto obedeceu a critérios de natureza mais estritamente geográfica. Como me disse um dos imperadores a esse propósito: «levei a vizinhança de perto a eito, para não ofender ninguém». No Primeiro Império de Santa Bárbara, além dos vizinhos de perto da sua casa no Termo da Igreja - onde estava instalada a Coroa - o imperador, um emigrante retornado há 6 meses à freguesia, convidou também para ajudantes os vizinhos de perto da sua casa em São Lourenço, onde residia.
} 


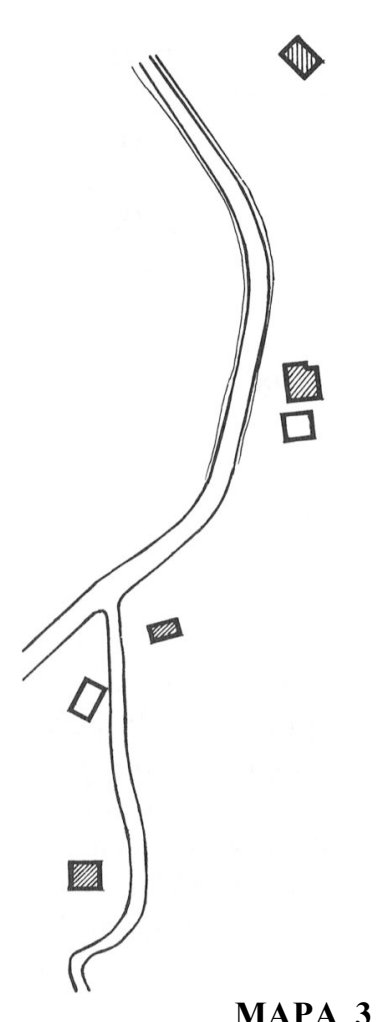

MAPA 3

Ajudantes e vizinhos de perto (Primeiro Império de Santa Bárbara, 1987)

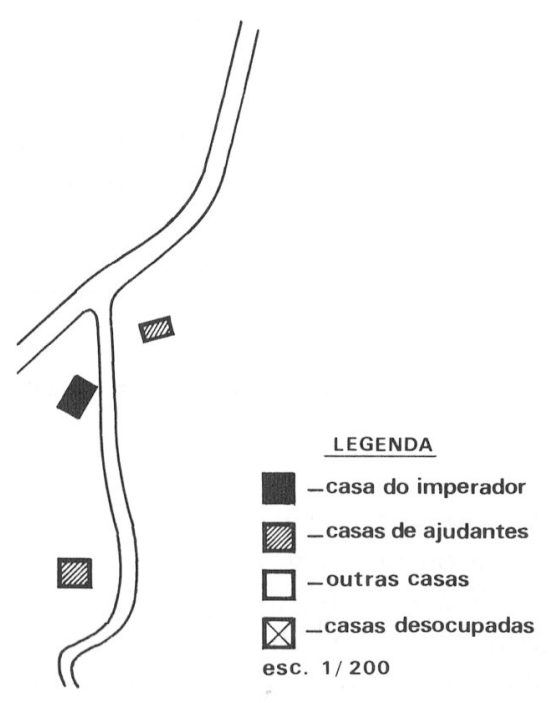

MAPA 4

Ajudantes e vizinhos de perto (Segundo Império de Santa Bárbara, 1987)

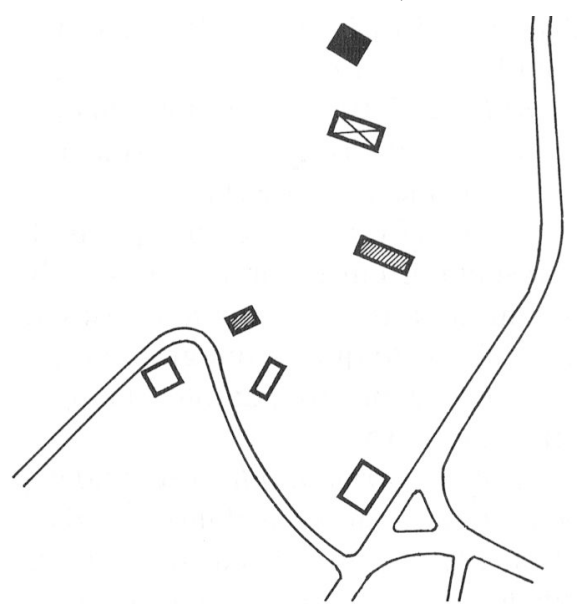

MAPA 5

Ajudantes e vizinhos de perto (Segundo Império do Norte, 1987)

Assentando de forma privilegiada nas prestações alimentares consagradas aos ajudantes, o vínculo entre a linguagem da dádiva alimentar e a reiteração 


\begin{tabular}{lcc}
\hline & IRMANDADES & PARENTES \\
\hline Primeiro Império de Santa Bárbara & 132 & 31 \\
Segundo Império de Santa Bárbara & 174 & 47 \\
Primeiro Império do Norte & 120 & 28 \\
Segundo Império do Norte & 146 & 26 \\
\hline
\end{tabular}

QUADRO 15

Irmandades e parentes (Santa Bárbara, 1987)

das relações de parentesco e de vizinhança de perto do imperador, possui ainda outras expressões.

E à sua luz que pode ser interpretada a prática, que se tem vindo a tornar corrente em muitos Impérios, de alargar a esfera de circulação de algumas distribuições alimentares destinadas exclusivamente aos ajudantes a outras unidades domésticas que, embora ligadas por laços de parentesco - geralmente de segundo grau — ou de vizinhança ao imperador, não fazem formalmente parte do grupo de ajudantes. Esse alargamento intervém sobretudo em relação à Ceia inicial dos Ajudantes. Mas nalguns casos, abrange mesmo a distribuição porta-a-porta de escaldadas. No Primeiro Império do Norte, por exemplo, a imperatriz - uma mulher dotada de uma memória genealógica particularmente apurada - distribuiu escaldadas à totalidade dos seus parentes, inclusivamente em terceiro grau, residentes na freguesia: cerca de vinte escaldadas suplementares foram dessa forma distribuídas.

É também neste quadro que pode ser analisada a particular densidade que apresentam, entre parentes e vizinhos de perto, as ofertas feitas ao imperador no âmbito da irmandade. Envolvendo a maior parte dos parentes e vizinhos de perto que se integram no grupo de ajudantes, essas ofertas estendem-se ainda a outros parentes tanto residentes na freguesia, como emigrados (cf. quadro 15).

Entre as irmandades oferecidas por parentes, merecem relevo especial pelo importante contributo que dão para o financiamento do Império - as ofertas feitas em cabeças de gado. Como decorre do quadro 16, a quase totalidade dessas ofertas - ou mesmo a sua totalidade — são de facto feitas por parentes do imperador.

Os próprios mecanismos de reciprocidade diferida a que, como assinalámos, a irmandade dá lugar, fazem também intervir critérios relacionados com o parentesco. De facto, algumas das irmandades recebidas pelo imperador visam retribuir, em certos casos, ofertas anteriormente feitas por familiares próximos a casas que no passado realizaram também um Império. 


$\begin{array}{ccc}\text { TOTAL DE } & \text { CABEÇAS GADO } & \text { CABEÇAS GADO } \\ \text { CABEÇAS GADO } & \text { OFERECIDAS } & \text { OF. P/ PARENTES }\end{array}$

\begin{tabular}{lccc}
\hline $\begin{array}{c}\text { Primeiro Império } \\
\text { de Santa Bárbara }\end{array}$ & 8 & 3 & 3 \\
$\begin{array}{c}\text { Segundo Império } \\
\text { de Santa Bárbara }\end{array}$ & 8 & $2 \frac{1}{2} 2$ & $1 \frac{1}{2}$ \\
$\begin{array}{c}\text { Primeiro Império } \\
\text { do Norte }\end{array}$ & 6 & 1 & 1 \\
$\begin{array}{c}\text { Segundo Império } \\
\text { do Norte }\end{array}$ & 7 & $4 \frac{1}{2}$ & 3 \\
\hline
\end{tabular}

\section{QUADRO 16 \\ Cabeças de gado oferecidas por parentes (Santa Bárbara, 1987)}

Operando sobretudo como um instrumento de asserção das relações sociais no âmbito das esferas do parentesco e da vizinhança de perto de cada imperador, a irmandade fornece também um contexto favorável à reafirmação dos laços sociais entre outras unidades domésticas. Assim, a confecção dos pães de mesa e roscas envolve, em muitos casos, o estabelecimento de laços de cooperação entre vizinhos de perto e parentes, seja por intermédio de trocas de mão, seja por intermédio da preparação conjunta da massa sovada. Por outro lado, o facto da irmandade enquanto oferta feita ao imperador implicar da parte deste uma contra-prestação alimentar, é também utilizado, sobretudo pelos emigrantes, como uma forma de presentear indirectamente certas casas. Em vez de ser entregue ao ofertante, a contra-prestação é distribuída a uma casa por ele indicada, geralmente de

\begin{tabular}{lcc}
\hline & IRMANDADES & RECONHECIMENTOS \\
\hline $\begin{array}{c}\text { Primeiro Império } \\
\text { de Santa Bárbara } \\
\begin{array}{c}\text { Segundo Império } \\
\text { de Santa Bárbara }\end{array}\end{array}$ & 132 & 31 \\
$\begin{array}{c}\text { Primeiro Império } \\
\text { do Norte }\end{array}$ & 174 & 47 \\
$\begin{array}{c}\text { Segundo Império } \\
\text { do Norte }\end{array}$ & 120 & 28 \\
\hline
\end{tabular}

QUADRO 17

Irmandades e reconhecimentos (Santa Bárbara, 1987) 
um parente. O copeiro, além de escrever no papel que acompanha a irmandade o nome da pessoa que fez essa oferta, dá também instruções específicas ao ajudante que assegura a sua entrega para referir oralmente o facto. Esta utilização da irmandade - designada correntemente sob a forma de reconhecimento - é relativamente comum, conforme se pode verificar no quadro 17. 
CAPÍTULO 5

A PARTE DOS HOMENS II 
Ao lado desta dimensão sociológica restrita, as formas de circulação cerimonial do alimento que integram a sequência ritual dos Impérios possuem simultaneamente uma dimensão sociológica mais ampla e decisiva. Essa dimensão diz respeito às duas instâncias centrais sobre as quais assenta o sistema social local: o lugar e a freguesia.

O lugar constitui, como vimos, uma unidade base do povoamento e da organização espacial da freguesia. Mas constitui também uma unidade sociologicamente relevante. Os termos exactos dessa relevância merecem um exame mais aprofundado. Alguns estudos de etnologia portuguesa habituaram-nos a ver no lugar e em unidades de povoamento similares - apesar da sua irrelevância formal em termos politico-administrativos e religiosos - um quadro estruturador central da vida social nas comunidades rurais Assim, na região «saloia» estudada por Joyce Riegelhaupt, «a aldeia local é de importância fundamental nas relações sociais» (1973: 846). As aldeias não têm fronteiras administrativas. No entanto, «cada povoação (...) é vista pelos seus habitantes e pelos seus vizinhos como, de algum modo, única e mesmo fechada sobre si própria (...). Pequenas diferenças são cultivadas pelos aldeãos (...) e (...) cuidadosamente consideradas na definição do 'nós' da aldeia versus todos os outros 'eles'» (id.: 845). «Existem rivalidades intensas entre aldeias vizinhas» e "para um rapaz, fazer a corte a uma rapariga de outra aldeia da freguesia é, muitas vezes, uma experiência arriscada» (id.: 848). Debruçando-se sobre as festas patronais, a autora salienta também a sua importância enquanto meios de que as aldeias se socorrem «para afirmar a sua identidade e a sua unidade contra toda a freguesia» (id.: 845). No estudo que dedicou a duas freguesias do Alto Minho, Pina Cabral pôs em evidência um contexto algo similar. Segundo ele, «o lugar é (...) o solo da comunidade sobre o qual são construídos os outros níveis. E ao nível do 
lugar que o individuo aprende a experiência da comunidade e integra os valores que a corporizam na sociedade rural minhota» (1986: 127). Paralelamente, é também possível falar, nestes contextos, de uma menor importância sociológica da freguesia, cujas funções seriam sobretudo de natureza político-administrativa e religiosa. Assim, segundo Joyce Riegelhaupt, em São João das Lampas, «as unidades territoriais da província e da freguesia [os itálicos são meus], tornaram-se menos significativas para os aldeãos e as unidades locais demonstram menos interesse em cooperar entre si» (1973: 845). Pina Cabral salienta também o modo como, ao nível da freguesia, «as relações entre [os seus] membros são mais frágeis do que as relações existentes no interior do lugar (...). De igual modo, a confiança mútua, que é mais acentuada ao nível do lugar, tem menos oportunidade de se manifestar ao nível da freguesia» (1986: 126-127).

Em Santa Bárbara deparamo-nos com uma situação diferente. Não se pode evidentemente negar ao lugar uma certa «personalidade» sociológica. A maior proximidade física entre as casas no interior do lugar tende a tornar mais fortes os laços de relacionamento e interacção social nesse âmbito. Mas, simultaneamente, nota-se um peso importante da tendência oposta, que se encarrega de projectar permanentemente o lugar para o exterior, inserindo-o numa cadeia mais vasta de relações. Essa tendência pode ser surpreendida em vários planos convergentes.

No plano económico, ao lado da propriedade detida no âmbito do lugar, é igualmente importante o peso das terras dispersas por outros lugares. De facto, no conjunto da freguesia, cerca de $60 \%$ das terras situam-se fora do lugar de residência dos respectivos proprietários. Esta dispersão é aliás enfaticamente valorizada do ponto de vista da complementariedade da exploração agrícola. Considera-se que determinados lugares têm uma aptidão especial para certas culturas e o agricultor ideal é aquele que tem vinha em São Lourenço ou nas Lagoinhas, terras de trigo no Norte, matos nas Pocilgas, milho e hortas mais ao pé de casa e pastos dispersos um pouco por todo o lado.

No plano matrimonial a tendência prevalecente vai no sentido da exogamia. Essa tendência transparece de forma clara nos números. Assim, num universo de 209 casamentos, correspondente às 214 unidades domésticas existentes em 1987 na freguesia, cerca de metade - 104, isto é, perto de 50\% - realizou-se entre indivíduos provenientes de lugares diferentes. Os dados referentes ao total de casamentos realizados na freguesia entre 1917 e $1982^{1}$

\footnotetext{
${ }^{1}$ Estes dados resultam de um apuramento efectuado nos registos paroquiais de casamentos respeitantes ao período de 1917 a 1982. Por carência de dados não foi possível levar em linha de conta para o cálculo das taxas de endogamia e exogamia a nível de lugar e de freguesia, os anos de 1950 a 1955, inclusive. Por outro lado, os dados referentes a 1939, 1940 e 1958 foram extraídos de séries incompletas. Do total de 633 casamentos celebrados no período em questão foram levados em conta, para estes cálculos, 615 casamentos.
} 


\begin{tabular}{lrr}
\hline LUGARES & $\begin{array}{c}\text { \% DE CASAMENTOS NO } \\
\text { EXTERIOR DO LUGAR }\end{array}$ & $\begin{array}{c}\text { NÚMERO DE LUGARES } \\
\text { QUE FORNECEM PARCEIRO } \\
\text { MATRIMONIAL }\end{array}$ \\
\hline São Lourenço & $71,4 \%$ & 4 \\
Forno & $55 \%$ & 6 \\
Arrebentão & $71 \%$ & 10 \\
Pocilgas & $84,6 \%$ & 8 \\
Pico do Penedo & $90,5 \%$ & 11 \\
Boavista & $94,4 \%$ & 9 \\
Termo da Igreja & $74,4 \%$ & 13 \\
Barreiro & $90,9 \%$ & 9 \\
Norte & $61,7 \%$ & 11 \\
Poço Grande & $84,4 \%$ & 11 \\
Lagos & $95,9 \%$ & 7 \\
Ribeira do Amaro & $91,1 \%$ & 9 \\
Feteiras & $88,7 \%$ & 6 \\
Lagoinhas & $62 \%$ & \\
\hline
\end{tabular}

\section{QUADRO 18 \\ Exogamia de lugar em Santa Bárbara (1917-1982)}

são ainda mais expressivos. Com excepção de três lugares - Forno, Norte, Lagoinhas - a taxa de exogamia de lugar situa-se sempre acima dos $70 \%$ (cf. quadro 18).

Em consequência, existe um forte índice de dispersão parental pelos diferentes lugares: do total de parentes de primeiro grau - pais, filhos e irmãos - de que cada grupo doméstico dispõe na freguesia, cerca de $56 \%$ residem em lugares distintos.

O plano do ritual acusa um perfil similar. Em certas ocasiões - tanto no quadro do ciclo festivo como no quadro dos ritos de morte - o lugar, ou no caso de lugares mais pequenos, o compromisso, surgem como unidades pertinentes. Nos funerais, por exemplo, deveria integrar-se obrigatoriamente um elemento de cada uma das casas do lugar onde residia o morto - hoje em dia essa participação estende-se idealmente ao conjunto de casas da freguesia - e o transporte do caixão era assegurado por três ou quatro dessas casas, escolhidas de acordo com um sistema rotativo. Mas o que é determinante no sistema ritual é o facto de ele exceder as fonteiras do lugar. Por fim, embora cada lugar possua uma certa consciência de si, são particularmente fracas as expressões do facto. Não existem ápodos característicos deste ou daquele lugar e as rivalidades inter-lugares são também muito diluídas. 


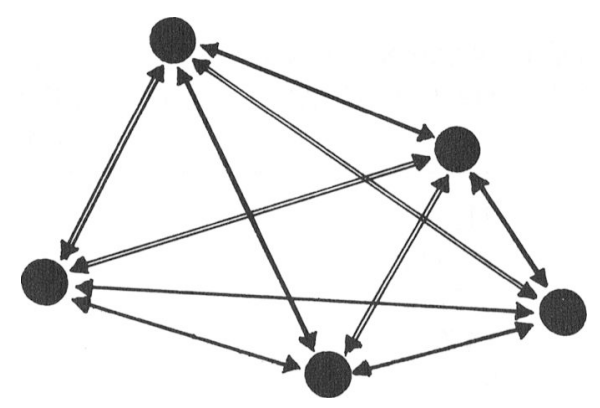

FIGURA 4

Integração recíproca dos lugares

A «personalidade» do lugar é pois permanentemente corrigida por urna tendência «exo-prática» que faz dele não uma unidade fechada sobre si própria mas um termo de uma cadeia de relações mais ampla (cf. figura 4).

Essa cadeia de relações é a freguesia. Se nos contextos que referimos atrás, a força do lugar era directamente proporcional à fraqueza da freguesia, em Santa Bárbara, o lugar, ao prescindir do seu «quant a soi» fá-lo justamente em nome de uma acrescida relevância sociológica da freguesia. Esta, além da sua importância formal em termos político-administrativos e religiosos, opera de facto como um quadro estruturador central das relações sociais.

No plano económico, à dispersão da propriedade pelos diferentes lugares da freguesia, contrapõe-se a sua concentração no interior da freguesia. Do total de terras detido pelos grupos domésticos da freguesia apenas cerca de $8 \%$ se situa fora da freguesia. No plano matrimonial, de forma similar, à exogamia prevalecente no lugar, opõe-se uma forte endogamia ao nível da freguesia. Assim, no total de casamentos realizado entre 1918 e 1982, apenas 12,5\% se realizaram com indivíduos de outras freguesias. Da mesma maneira, no universo de 209 casamentos correspondentes às 214 unidades domésticas existentes em 1987 na freguesia, apenas 30 casamentos - isto é, perto de $14 \%$ do total - eram casamentos exogâmicos ${ }^{1}$. No plano do ritual, a freguesia constitui também- como teremos ocasião de verificar mais detalhamente -

\footnotetext{
${ }^{1}$ Exogamia de lugar e endogamia de freguesia devem ser consideradas em conjunto. A exogamia de lugar, juntamente com as proibições de casamento entre consanguíneos, interdita o casamento nas áreas marcadas por uma proximidade excessiva. A endogamia de freguesia interdita o casamento em círculos sociais onde a distância é considerada também ela excessiva. Adaptando uma formulação de Françoise Zonabend, pode-se também dizer, a propósito de Santa Bárbara, que o jogo da aliança consiste «em manter um compromisso equilibrado (...) entre $o$ muito próximo e o não muito distante» (Zonabend, 1981: 314).
} 
a unidade central que o protagoniza ou é por ele nomeada. Convergentemente com estes factos, os habitantes de Santa Bárbara possuem uma elevada consciência de si próprios, constantemente reafirmada através do contraste que postulam com as restantes freguesias da ilha. E esse contraste que um dos ditados que todos os marienses conhecem põe em evidência:

«Os da Serra são labregos

os da Vila cidadães

d'Almagreira são lapujas

de São Pedro lambuzães».

Assumindo-se como labregos, homens da Serra ou serranos, os habitantes de Santa Bárbara mantêm com os habitantes das restantes freguesias uma relação que oscila entre a desconfiança e a rivalidade. A primeira é dominante em relação à Vila «stricto sensu». Era na Vila que, num passado ainda recente, os camponeses de Santa Bárbara pagavam os foros às grandes famílias de Santa Maria ou aos conventos aí estabelecidos. Ainda hoje a Vila começa por ser o sítio onde se pagam impostos e onde residem os intermediários de gado: os novos representantes da exploração de que os camponeses se sentem alvo. Por outro lado, a partir da construção do aeroporto, acentuou-se na metade ocidental da Ilha uma certa tendência para a terciarização da economia que Santa Bárbara não acompanhou. Os ressentimentos passados e presentes, combinados com o fosso entre modos de vida que se instalou mantêm viva a desconfiança entre «serranos» e Vila. Essa desconfiança estende-se ainda, embora de forma menos pronunciada, às freguesias de São Pedro e Almagreira que, situando-se na metade oeste da ilha — «para lá dos Picos» - são consideradas como uma espécie de extensão rural da Vila. Quanto à rivalidade inter-freguesias, além de outras expressões mais genéricas, é sobretudo no quadro das ocasiões festivas que ela se exprime. Além de uma competição surda para fazer «a festa mais bonita», essas ocasiões fornecem também o contexto para o desencadear de conflitos, por vezes violentos, entre grupos pertencentes a freguesias diferentes ${ }^{1}$.

O vínculo entre os Impérios e estas duas unidades sociais estabelece-se em primeiro lugar por intermédio da participação que elas têm na constituição do fundo cerimonial do Império.

${ }^{1}$ A importância destas formas de «sociocentrismo» num contexto, como o de Santa Bárbara, tão fortemente marcado pelo povoamento disperso deve ser sublinhada. Ela desmente o carácter exclusivo da equação, defendida por alguns antropólogos, entre povoamento concentrado e «sociocentrismo» (cf., por exemplo, Tak, 1990). 


\begin{tabular}{|c|c|c|}
\hline & $\begin{array}{l}\text { TOTAL DE } \\
\text { IRMANDADES }\end{array}$ & $\begin{array}{l}\text { TOTAL DE CASAS QUE } \\
\text { FIZERAM IRMANDADE }\end{array}$ \\
\hline \multicolumn{3}{|l|}{ Primeiro Império } \\
\hline de Santa Bárbara & 132 & 89 \\
\hline \multicolumn{3}{|l|}{ Segundo Império } \\
\hline de Santa Bárbara & 174 & 108 \\
\hline \multicolumn{3}{|l|}{ Primeiro Império } \\
\hline do Norte & 120 & 55 \\
\hline \multicolumn{3}{|l|}{ Segundo Império } \\
\hline do Norte & 146 & 182 \\
\hline Total & 562 & 145 \\
\hline
\end{tabular}

Essa participação começa por associar idealmente aos Impérios o conjunto da freguesia. No passado, uma parte importante dessa contribuição tinha lugar no quadro dos peditórios realizados por ocasião das colheitas e que englobavam, de acordo com os testemunhos orais, a quase totalidade das casas da freguesia: «todos davam; um dava um punhado de trigo, outro um tanto de milho; todos davam». Com o declínio desses peditórios, a participação da freguesia passou entretanto a fazer-se de forma preferencial no quadro da irmandade. Começando por evidenciar - como vimos atrás - uma particular densidade no interior das esferas de parentesco e de vizinhança de perto do imperador, essas ofertas associam simultaneamente aos Impérios um número significativo de casas da freguesia, correspondente a 60 a $70 \%$ do total.

Nos anos em que se realiza um só Império, ele tende a concentrar a totalidade das ofertas. Nos anos em que se realizam vários Impérios, sobretudo se estes têm lugar na mesma altura, essa participação tende a dispersar-se pelo conjunto dos Impérios. Embora exista um grande número de casas que faça ofertas a mais de um Império, muitas optam por «fazer a irmandade» a um deles, com exclusão dos outros. Foi justamente o que se passou em 1987.

Como se pode verificar no quadro 19,145 das 214 casas da freguesia isto é, $68 \%$ do total - contribuíram com pelo menos uma oferta para cada um dos quatro Impérios. O Primeiro e o Segundo Impérios de Santa Bárbara receberem o maior número de ofertas, correspondentes respectivamente a $42 \%$ e $50 \%$ das casas da freguesia. O Primeiro Império do Norte foi o que teve uma irmandade mais baixa - correspondente a $26 \%$ das casas da freguesia — e, por fim, o Segundo Império do Norte beneficiou da participação de 39\% das casas da freguesia. 
A maior parte dos grupos domésticos que não intervêm na irmandade correspondem - de forma significativa - a casas com uma inserção deficiente na comunidade. Muitas delas são casas com um estatuto económico ou social baixo: casas mais pobres, por um lado, ou casas constituídas por pessoas idosas. Outras correspondem por seu turno a casas que - para utilizar a expressão mais correntemente usada a esse respeito em Santa Bárbara - «estão em si», isto é, que se colocam de forma deliberada à margem da comunidade.

Não deixa entretanto de ser significativo que, sobretudo em relação às casas citadas em primeiro lugar, exista de alguma forma a preocupação de, por intermédio das esmolas, as reintegrar ficticiamente na irmandade. Embora não participem na irmandade enquanto prestação oferecida ao Império, essas casas, ao serem beneficiadas com a irmandade enquanto contra-prestação assegurada pelo imperador, são tratadas «como se» tivessem realizado essa oferta.

Alargando-se ao conjunto da freguesia, a participação na irmandade assume, ao nível do lugar de residência do imperador, contornos particulares. E aí que a participação da comunidade é mais enfatizada e idealmente mais constrangente, sobretudo se, no mesmo ano, se realizam vários Impérios cujos imperadores pertencem a lugares diferentes. As casas que nesses lugares não estão em condições de realizar ofertas a todos os Impérios, optam frequentemente por privilegiar o Império promovido no quadro do seu lugar: «se tiver que deixar algum para trás, então deixo um que seja doutro lugar». Alguns dados relativos aos Impérios realizados em 1987 podem ser interpretados a esta luz. Assim, no Primeiro Império do Norte, promovido por um imperador residente nesse lugar, foi aí que foi mais elevada a proporção entre o número de irmandades e o número de casas: seis irmandades em dez casas, contra duas, quatro e cinco respectivamente no Primeiro e Segundo Impérios de Santa Bárbara e no Segundo Império do Norte. O facto de estes Impérios terem sido todos eles realizados por imperadores residentes no Termo da Igreja, embora tenha provocado uma certa dispersão de ofertas, teve também uma tradução numérica relevante. Assim, o Primeiro Império de Santa Bárbara recebeu aí trinta e uma ofertas - correspondentes a $58 \%$ das casas do lugar - o Segundo Império de Santa Bárbara, trinta e quatro - correspondentes a $64 \%$ das casas - e o Segundo Império do Norte, vinte e cinco - correspondentes a $47 \%$ das casas. No conjunto, estes três Impérios contaram com a participação de $81 \%$ das casas do lugar contra apenas $19 \%$ do Primeiro Império do Norte.

É possível dar exemplos semelhantes para outros anos. Assim, em 1982, um dos cinco Impérios que teve lugar na freguesia foi promovido por um imperador residente no lugar do Poço Grande, encontrando-se os restantes quatro a cargo de imperadores residentes no Termo da Igreja. Enquanto que as irmandades alcançadas por esses imperadores no Poço Grande não ultrapassaram $50 \%$ das casas aí residentes, o outro imperador recebeu um total de vinte e duas ofertas correspondentes à totalidade das doze casas então existentes no lugar. Da mesma forma, em 1986, um dos Impérios realizado na freguesia, foi promovido por um imperador residente nas Lagoinhas. 
As casas desse lugar que - inclusivamente por razões que teremos ocasião de expor mais adiante - se associam de forma geralmente deficiente à realização dos Impérios, tiveram então uma participação particularmente significativa na irmandade, correspondente a $72 \%$ das casas.

E justamente este empenhamento do conjunto da comunidade nos Impérios que reflecte o cortejo que, no termo da fase preliminar do Império, procede à transferência da sede dos festejos da casa do imperador para a igreja ou ermida para a qual ele foi prometido. Marcado, como vimos, pelo relevo que nele ocupa o transporte cerimonial dos pães de mesa e roscas oferecidos no quadro da irmandade, ele opera como um momento particularmente importante de afirmação da freguesia. Um cuidado muito especial é posto na sua correcta organização, bem como na sua expressividade estética, valorizadas justamente enquanto demonstração do envolvimento colectivo da freguesia nos Impérios.

Assumindo um papel determinante no financiamento dos festejos, o lugar e a freguesia constituem simultaneamente as unidades sociais privilegiadas pelos critérios que presidem à circulação ampliada do alimento. Começando por estar ao serviço da reafirmação das relações de parentesco e de vizinhança de perto do imperador, as refeições e distribuições alimentares previstas na sequência ritual dos Impérios actuam num segundo momento como um instrumento ao serviço de um projecto sociológico mais largo - cujo sentido exacto teremos ocasião de precisar no próximo Capítulo - mas que podemos caracterizar provisoriamente como um projecto de reiteração das instâncias mais amplas da organização social local e de asserção da sua identidade. É justamente nessa medida que a comunidade — designadamente por intermédio da irmandade - se empenha em secundar os desempenhos do imperador. E é também ao serviço deste projecto sociológico mais vasto que estes últimos se acabam por colocar.

Esse projecto começa por esboçar-se, de uma forma ainda tacteante, na fase preliminar do Império, para atingir o seu apogeu em dia de Império.

Por seu intermédio, começamos de novo por ser confrontados com a figura do lugar. As distribuições alimentares amplas de um Império começam de facto, como vimos, por reservar ao lugar — ou, no caso dos lugares mais pequenos, ao compromisso - um importante papel. Assim, no quadro da distribuição porta-a-porta de Sopas do Espírito Santo que se realiza no início da fase preliminar do Império, os vizinhos do lugar do imperador apresentam direitos alimentares próprios. Esses direitos transitam depois, em dia de Império, para os vizinhos do lugar onde se situa a igreja ou ermida para a qual o Império foi prometido. Tradicionalmente, eles eram ainda beneficiados em dia de Império com uma distribuição especial de massa sovada. 
Mas a figura central que as distribuições alimentares alargadas acabam por fazer emergir com maior clareza é de novo a freguesia. De facto, as distribuições porta-a-porta de Sopas do Espirito Santo, além dos ajudantes e dos vizinhos de lugar, incidem ainda sobre categorias precisas de casas à escala da freguesia. A distribuição que se realiza no início da fase preliminar do Império abrange como vimos o conjunto dos enfermos da freguesia. Quanto à distribuição que tem lugar em dia de Império, além destes, envolve ainda os anojados. Da mesma maneira, em dia de Império, é aos anojados que se destinam as primeiras corridas de massa sovada e de vinho.

E entretanto no quadro das distribuições generalizadas e abertas de Sopas do Espírito Santo e de massa sovada características de dia de Império que o vínculo entre a circulação cerimonial do alimento e a reiteração da identidade da freguesia se afirma de forma mais expressiva.

Esta desenha por um lado o quadro preferencial de circulação do alimento. As distribuições abertas de Sopas do Espírito Santo e de massa sovada começam por reunir em seu torno um grande número de vizinhos e é entre eles que os alimentos distribuídos são primeiro que tudo consumidos e partilhados. O dia de Império pode nessa medida começar por ser definido como uma grande refeição colectiva extensiva ao conjunto da freguesia, por intermédio da qual se reafirmam os laços de pertença à comunidade e esta se dá como um corpo social unificado.

Estas características de dia de Império expressam-se de uma forma particularmente clara na «abertura» de dia de Império, quando são asseguradas, no termo da missa da coroação, as primeiras mesadas de Sopas e as primeiras corridas de massa sovada e de vinho. A concentração das pessoas da freguesia no recinto do Império é então máxima e é sobretudo entre elas que o alimento circula. Os critérios que, ao longo do dia, presidem ao acesso ao quarto da imperatriz põem também em relevo este nexo preferencial entre a comunidade e o alimento distribuído. É sobretudo entre os vizinhos da freguesia que é convidada a maior parte das pessoas que a ele têm acesso.

E justamente para estas preocupações de efectiva e exaustiva partilha do alimento entre a comunidade que remete também o tratamento especial reservado aos anojados em dia de Império, tanto no quadro da distribuição matinal de Sopas do Espirito Santo, como, depois, no quadro das corridas de massa sovada que têm lugar após o termo da missa da coroação. Num e noutro caso, aquilo que se procura garantir é que, apesar das restrições que o código do luto impõe à participação dessas pessoas nos festejos, elas sejam de qualquer forma abrangidas pela circulação do alimento. Da mesma maneira, nos últimos anos, tem-se vindo a generalizar o hábito de proceder a uma primeira distribuição de massa sovada e de vinho - e por vezes de Sopas na véspera do dia de Império, no termo da missa antecipada de sábado. Em muitos casos, as pessoas que acorrem a essa missa, sobretudo se moram em lugares mais afastados, não voltarão a deslocar-se ao recinto do Império, procurando justamente essas distribuições antecipadas garantir que também elas partilhem do alimento distribuído. 
A liberalidade e a amplitude que caracterizam a circulação do alimento em dia de Imperio estende-se em segundo lugar às pessoas de fora da freguesia que, acorrendo em grande número aos festejos, são convidadas a associar-se às distribuições alimentares em curso.

Essa faceta dos festejos exprime-se desde logo no caldo de meia noite. Esta distribuição de Sopas realizada na véspera de dia de Império abre-se de facto privilegiadamente para o exterior da freguesia: «os de cá nunca vêm ao caldo, isso é para os de fora». Mas é no dia de Império propriamente dito que o afluxo «dos de fora» assume proporções mais importantes. Se nesse dia se realizam vários Impérios na ilha, tendem a organizar-se verdadeiras excursões que percorrem sucessivamente os vários Impérios. Se se trata do único Império, ele torna-se no polo de atracção principal da população da ilha.Esta abertura em relação ao exterior possibilita que a freguesia disponha, no momento em que se afirma como um corpo social unificado, de um parceiro colectivo por referência ao qual pode reivindicar de forma plena a sua identidade. Operando como o instrumento por excelência dessa abertura, o alimento é também o terreno principal sobre o qual assentam essas reivindicações. A lógica sobre a qual estas se fundam possui similitudes flagrantes com aquela que os antropólogos reconheceram a propósito do potlatch. O alimento, e, em particular, a liberalidade e a amplitude com que é distribuído, funciona como um signo do prestígio colectivo da freguesia. Convidados a partilharem o alimento, os forasteiros são também e sobretudo convidados a testemunhar as pretensões a prestígio da freguesia. Esta faceta dos festejos é fortemente enfatizada pelos habitantes da freguesia que reclamam serem os seus Impérios os mais fortes da ilha, aqueles onde é abatido um maior número de cabeças de gado e onde a irmandade é também mais forte ${ }^{l}$. Simultaneamente, é posta grande ênfase na qualidade dos alimentos distribuídos, assim como na sua apresentação estética. A decoração dos pães de mesa e das roscas - baseada, como vimos, em motivos florais — é, em particular, fortemente acentuada. Começando por se afirmar em torno do cortejo que leva o Império para a copeira, é entretanto em dia de Império que estas reivindicações se exprimem de forma mais clara. O maior ou menor afluxo de forasteiros, os comentários por eles produzidos a respeito do Império, fornecem de facto o contexto principal para que elas se manifestem e actualizem periodicamente.

Simultaneamente, o dia de Império fornece um quadro propício ao sublinhar das diferenças inter-freguesias, tal como estas se expressam na estrutura ritual dos Impérios. De facto, embora se integrem no modelo genérico

\footnotetext{
${ }^{1}$ Estas reivindicações, no tocante a Santa Bárbara, possuem um certo fundamento. De facto, enquanto que em Santa Bárbara, o número médio de cabeças de gado abatida por Império é de sete, nas restantes freguesias da ilha ele situa-se por volta das quatro/cinco. Para o cálculo destes números, baseei-me nos requerimentos dirigidos à Câmara Municipal de Vila do Porto respeitantes aos anos de 1965 a 1983.
} 
de Impérios prevalecente na ilha de Santa Maria, os Impérios de Santa Bárbara apresentam um certo número de diferenças em relação aos Impérios das restantes freguesias da Ilha. Essas diferenças são particularmente acentuadas em relação às freguesias da metade oeste da Ilha — Vila, São Pedro e Almagreira - e começam por dizer respeito à organização da vertente religiosa dos festejos. Assim, nessas freguesias, a coroação, em vez de incidir sobre o imperador, incide sobre uma criança, o menino ou menina da mesa, geralmente um filho (ou uma filha) do imperador, de idade compreendida entre os quatro e os oito anos de idade. A organização dos cortejos processa-se também de forma diferente, designadamente no tocante às posições relativas e funções dos ajudantes grados. Por outro lado, na Vila, generalizou-se o costume de colocar à cabeça do cortejo que leva o Império para a copeira um conjunto de estandartes do Espírito Santo e de pequenas Coroas do Espírito Santo transportadas por grupos de três a quatro meninas ou raparigas vestidas de branco.

Certos aspectos da vertente alimentar dos Impérios apresentam também, nas freguesias da metade oeste, uma estruturação diferente. E o que se passa, em primeiro lugar, com a composição culinária das Sopas do Espírito Santo. Estas, em vez de serem temperadas com hortelã e canela, são temperadas com endro. Parecendo insignificante, este pequeno detalhe é extremamente valorizado pelas pessoas. Em Santa Bárbara é frequente ouvir-se comentários desvalorizadores do tempero usado nas freguesias da Vila, terminando invariavelmente na afirmação da superioridade das Sopas da Serra: «são mais saborosas», «o endro não dá tanto sabor», etc...

A retribuição das ofertas feitas ao imperador no quadro da irmandade, processa-se também de forma distinta, compreendendo três tipos principais de contra-prestações: as flores ou pensões, as bandejas e os tabuleiros. As flores ou pensões retribuem as ofertas feitas em pães de mesa e roscas - ou em valor monetário equivalente - e constam de uma posta de carne pequena e de um brindeiro, ou de um pão de trigo. As bandejas correspondem a ofertas intermédias e são integradas por uma posta de carne ligeiramente maior, uma rosquilha de massa sovada — ou um pão de mesa pequeno — e um brindeiro. Finalmente, os tabuleiros retribuem as ofertas maiores - sendo também distribuídos aos ajudantes - e constam de uma posta de carne grande, de duas rosquilhas pequenas — ou de dois pães de mesa pequenos — de um pão leve e de um prato de biscoitos. Algumas das sequências alimentares de dia de Império apresentam também uma estrutura diferente. Assim, o ritual de abertura da mesa é enriquecido por uma cerimónia inédita, centrada justamente no(a) menino(a) da mesa. Antes de se iniciarem as primeiras distribuições de massa sovada e vinho, é-lhe servida no teatro uma pequena refeição cerimonial. Essa refeição consta de Sopas do Espírito Santo, água e três fatias de pão de trigo e é servida pelo trinchante que dá ele próprio de comer ao menino da mesa; no fim deve também lavar-lhe as mãos. As distribuições de massa sovada e vinho características de dia de Império estruturam-se tam- 
bém de uma forma diferente. Em primeiro lugar, a entrega de pães de mesa e roscas no teatro, não é objecto, como em Santa Bárbara, de qualquer cerimonialização. Em segundo lugar, a sua distribuição pública é feita em grande medida directamente no teatro, e não por intermédio de corridas especificamente organizadas para o efeito: estas são muito mais espaçadas e raras. Por outro lado, entre os alimentos distribuídos no teatro, conta-se também o pão leve.

Relativamente a Santo Espírito, existe também um certo número de diferenças, respeitantes quer à estrutura do grupo dos ajudantes - não existem pagens da mesa nem menino(a) da mesa e existe ainda um ajudante, conhecido pela designação de velho do canto, que secunda o trinchante nos seus desempenhos no teatro - quer a certas sequências cerimoniais precisas - a distribuição dos pães de mesa e roscas faz-se em moldes similares aos prevalecentes nas freguesias da metade oeste, a entrega destes no teatro não é também objecto de qualquer cerimonialização, etc... Embora menos pronunciadas do que as existentes em relação aos Impérios das freguesias da metade oeste $^{1}$, estas diferenças são entretanto objecto de uma valorização subjectiva muito forte.

O dia de Império fornece justamente o contexto adequado para que estas e outras diferenças sejam constatadas e sublinhadas. Fazendo-o, ele não só permite a reafirmação da especificidade da freguesia - tal como ela se expressa nesse acontecimento maior que são os Impérios - como possibilita a introdução de argumentos suplementares na discussão dos méritos relativos dos Impérios em cada uma das freguesias, centrada agora na sua maior ou menor conformidade em relação a esse modelo arquetípico - largamente imaginário, escusado será dizê-lo - constituído pelas Festas do Espírito Santo tal como estas teriam sido instituídas pela Rainha Santa Isabel.

Neste quadro tão fortemente marcado pela lógica da identidade, não é de admirar que a hospitalidade característica de dia de Império coexista em permanência com as atitudes opostas de reserva e hostilidade em relação ao exterior $^{2}$. Reserva, em primeiro lugar. Em contraste com a «cerimónia» que os vizinhos da freguesia exibem na sua aproximação ao alimento — «aos de cá,

\footnotetext{
${ }^{1}$ Neste sentido, é possível falar da existência em Santa Maria, de duas grandes variantes dos Impérios, uma predominante na metade oeste da ilha, outra na metade leste. Assim como no interior da variante oriental existem diferenças menores entre Santa Bárbara e Santo Espírito, na variante ocidental podem ser detectadas variações de pormenor de freguesia para freguesia. Para mais detalhes acerca deste aspecto dos Impérios de Santa Maria, cf. Leal, 1984a: 47-56.

${ }^{2}$ Esta correlação entre os valores aparentemente antitéticos da hospitalidade e da hostilidade é corrente (cf. Benveniste, 1969 e Pitt-Rivers, 1977) e parece partir, nas línguas latinas, da sua comum origem no termo hostis: inicialmente o estrangeiro e só depois o «inimigo público» (Benveniste, 1969: 321). O «outro» de qualquer forma. Mas um «outro» que começa por desenhar-se de uma forma particular - «não qualquer "estrangeiro", mas o estrangeiro que é pari iure cum populo Romano» (id. ibid.) - para só depois ganhar as cores antitéticas ora de hóspede, ora de hostil.
} 
quase que é preciso empurrá-los para a copeira» — «os de fora» são generalizadamente acusados de falta de respeito: «empurram-se à porta da copeira», «querem sempre os melhores bocados», etc... Por outro lado, enquanto que, em relação aos vizinhos da freguesia é salientada uma atitude de respeito para com o alimento, «os de fora» são acusados de desperdiçadores: «agarram num pedaço de pão de mesa e põem-no de lado», etc... Esta atitude geral de reserva e hostilidade em relação ao exterior manifesta-se ainda em torno do caldo da meia noite que, como vimos, reúne sobretudo forasteiros. A sua realização é, por essa razão, objecto generalizado de comentários desfavoráveis e muitos imperadores dizem que é a contragosto e só porque «é um costume da freguesia» que asseguram essa distribuição antecipada de Sopas. Suscitando reserva e desaprovação, os comportamentos que passámos em revista podem, no limite, criar situações em que as hostilidades se desencadeiam de forma mais aberta. Por vezes, ocorrem pequenas escaramuças à entrada da copeira. Do ajudante da porta da copeira diz-se aliás, em tom de brincadeira, que a sua insígnia deveria ser um pau, para usar nessas ocasiões. Muitas pessoas recordam também a frequência com que no passado, o dia de Império dava lugar a confrontos a ajustes de contas entre grupos de rapazes de Santa Bárbara e de Santo Espírito.

É justamente este misto de hospitalidade e hostilidade que é possível reencontrar nos desafios entrefolias ou cantadores pertencentes a freguesias diferentes. As boas-vindas e os elogios iniciais dão rapidamente lugar ao insulto e ao confronto verbal, com expressões que podem atingir por vezes grande violência. Seguidos atentamente pelas audiência, estes desafios permitem a expressão, sob uma forma eminentemente regulada e cerimonial, da rivalidade mútua entre freguesias.

Os mecanismos que passámos em revista - descritos a partir do ponto de vista de Santa Bárbara - funcionam nos dois sentidos. Ao mesmo tempo que o afluxo de forasteiros fornece à freguesia o parceiro colectivo indispensável à representação da sua identidade, para os próprios forasteiros essas visitas constituem também um mecanismo importante de reafirmação da pertença à sua própria freguesia.

Em 1983 realizou-se na freguesia de São Pedro um Império que constitui um exemplo particularmente elucidativo do que acabámos de afirmar. $\mathrm{O}$ imperador era casado com uma mulher de Santa Bárbara e, por essa razão, várias casas da freguesia tiveram nele uma participação importante. Cerca de metade dos ajudantes — dez em vinte e dois — eram de Santa Bárbara; de um total de cento e quarenta e duas irmandades, trinta e cinco — isto é, $25 \%$ - foram feitas por casas de Santa Bárbara; em dia de Império, por fim, os festejos registaram um afluxo particularmente importante de pessoas de Santa Bárbara. Ao longo do período em que decorreu a sua realização, este Império constituiu um dos assuntos preferidos de conversa na freguesia. Confrontadas 
com as diferenças existentes quanto à estruturação do Império, as pessoas faziam todo o tipo de comentários críticos, dominados por um «sociocentrismo» muito marcado. Nenhum aspecto do Império era poupado e o balanço final remetia invariavelmente para a afirmação da superioridade dos Impérios de Santa Bárbara.

\section{III}

Esta vocação sociológica dos Impérios reencontra-se de forma enfraquecida nas modalidades menores do culto do Espírito Santo constituídas pelas Esmolas e pelos Jantares. Embora repousem exclusivamente sobre o dispêndio cerimonial dos seus promotores, os critérios que presidem à circulação do alimento privilegiam mais uma vez o lugar e, no caso dos Jantares, a freguesia.

Mas é no quadro dos Impérios secos - cuja promoção reserva, como vimos, um papel mais importante à intervenção da comunidade - que ela apresenta contornos mais interessantes.

Comecemos pelo Império de São João. Na sua forma tradicional, ele configurava-se de alguma maneira como uma celebração em que um grupo de idade preciso - os rapazes — tomava a seu cargo a representação da unidade da freguesia. A partir da sua retoma, em 1986, esta sua vinculação ao grupo de idade dos rapazes desapareceu, para dar lugar a formas de intervenção que abrangem idealmente o conjunto das casas da freguesia. É entre elas, como vimos, que são sorteados os detentores dos cargos previstos na sua estrutura ritual e são também elas que são supostas fornecer a massa sovada e o vinho requeridos pela sua realização. Tanto por intermédio destas formas de participação da comunidade como por intermédio das modalidades de distribuição do alimento - similares àquelas que presidem à circulação de massa sovada e vinho em dia de Império -, o Império de São João permite que a freguesia se dê como um todo social unificado. Reunido e partilhado em comum pelas casas da freguesia, oferecido ainda aos forasteiros, o alimento opera mais uma vez como um instrumento de asserção da identidade da freguesia. A sua «recuperação» recente não pode aliás ser desligada da acção de mecanismos de rivalidade inter-freguesias. De facto nas freguesia de São Pedro e Santo Espírito realizam-se também tradicionalmente Impérios deste tipo, em São Pedro no dia de São João e em Santo Espírito no domingo da Trindade. Retomando a realização do Império de São João, a freguesia de Santa Bárbara fê-lo em certa medida para suprir aquilo que era sentido como um «handicap» em relação a essas freguesias. E a este respeito elucidativo que em 1986 - ano em que foi reatada a realização do Império de São João um dos seus principais motivos de atracção tenha sido fornecido por um «des- 
pique» entre a folia do Império e uma folia organizada expressamente para o efeito na freguesia de Santo Espírito.

\section{IV}

Quanto ao Império de São Pedro, o seu estatuto era bastante diferente. Como vimos, a sua realização assentava na cooperação entre os lugares do Forno - pertencente à freguesia de Santa Bárbara — e da Cruz de São Mor - pertencente à freguesia de Santo Espírito.

A realização deste Império parece constituir, em face de tudo aquilo que foi até agora referido, um verdadeiro paradoxo. Uma das ideias mais laboriosamente construídas pelos Impérios, a freguesia como um «nós social», cuja definição por oposição a um «eles» os Impérios exactamente possibilitam, parece aqui objecto de um desmentido.

A explicação deste paradoxo só é possível no quadro de uma consideração mais atenta da organização social tal como ela se configura nos lugares geograficamente periféricos da freguesia de que justamente o Forno faz parte, juntamente com as Lagoinhas - encostado à freguesia de São Pedro - e com o Norte - localizado no extremo norte da freguesia e cuja fronteira natural é o mar.

Nesses lugares, as linhas centrais da organização da estrutura social da freguesia, tal como a descrevemos atrás, conhecem de facto uma significativa inflexão. Por um lado, a tendência «exo-prática» prevalecente ao nível do lugar é aí menos forte. Assim, no plano matrimonial, a exogamia de lugar atinge nesses lugares valores que oscilam entre os $61 / 62 \%$ - Lagoinhas e Norte - e os $55 \%$ - Forno — , contra a média de $86 \%$ prevalecente nos restantes lugares (cf. quadro 18). Por outro lado, o número de casamentos consanguíneos que, no conjunto da freguesia se situa perto dos 12,5\%, atinge nestes lugares valores mais altos: $16 \%$ no Norte, $22 \%$ no Forno e $63 \%$ nas Lagoinhas ${ }^{1}$. O Norte, apesar da menor taxa de consanguinidade que apresenta, é comumente conhecido como sendo um lugar «onde todos são primos»: «começava-se a pedir a benção na primeira casa e acabava-se na última». Ainda hoje, o conjunto de dez unidades domésticas existentes no lugar formam dois «grupos de parentesco» - cada um deles com cinco casas - unidos entre si por relações de parentesco de primeiro grau. A tendência «endo-prática» prevalecente nestes lugares expressa-se também no plano da

\footnotetext{
${ }^{1}$ Os cálculos da taxa de consanguinidade foram feitos a partir dos pedidos de «dispensa eclesiástica» constantes dos registos paroquiais de casamento, relativos ao período de 1917 a 1982 .
} 
organização económica. Assim, a concentração da propriedade no interior do lugar é também maior: $72 \%$ no Norte, $81 \%$ no Forno e $90 \%$ nas Lagoinhas. No Norte, por outro lado, existe, para as debulhas, a única sociedade relativamente estável de inter-ajuda no trabalho agrícola. Integrada por cerca de dez casas, esta sociedade remonta a inícios deste século e desde então os direitos e deveres a ela associados têm-se transmitido de pais para filhos. Ora, como teremos oportunidade de sublinhar no próximo Capítulo, um dos aspectos mais marcantes das prestações e contra-prestações de trabalho associadas às debulhas é o seu carácter tendencialmente generalizado ao conjunto das casas da freguesia. Constituindo uma sociedade para o efeito, as casas do Norte como que se furtam a essa rede de trocas estabelecida à escala da freguesia.

Tudo parece passar-se, num primeiro momento, como se a situação periférica desses lugares os excluísse de alguma forma da rede de relações e trocas sobre as quais se funda a organização social, como se esta, desde a sua zona central, condenasse cada um deles a uma espécie de ensimesmamento, essencial à definição dos seus próprios limites conceptuais.

Num segundo momento, porém, esta aparente aceitação do convite ao ensimesmamento que é dirigido a cada um destes lugares é objecto de um desmentido. De facto, paralelamente à inversão da tendência, dominante na zona central da freguesia, para a integração recíproca dos lugares, assiste-se ainda, nos dois lugares periféricos que fazem fronteira com as freguesias vizinhas, à afirmação de uma relação privilegiada com estas, que desmente, também ela, as características de «endo-praxis» que, por referência à ideia de freguesia, o sistema social possui na sua zona central. Tanto no Forno, como nas Lagoinhas, de facto, a regra da endogamia ao nível da freguesia possui uma menor expressão. No Forno, por exemplo, os casamentos exogâmicos representam $55 \%$ dos casamentos recenseados. No plano da organização económica, detectam-se também tendências similares. Por um lado, é nesses lugares que é mais elevada a proporção de terras situadas fora da freguesia. Certos aspectos da organização do trabalho apontam no mesmo sentido. É o que se passa, mais uma vez com as debulhas do trigo. Em 1983, organizaram-se duas eiras na freguesia de Santa Bárbara: uma na Ribeira do Amaro e outra no Norte, a primeira para as casas da parte norte da freguesia e a segunda para as casas da parte sul. As casas que nas Lagoinhas tinham trigo para debulhar, preferiram fazê-lo numa das eiras situadas na vizinha freguesia de São Pedro. Em 1987 - ano em que se organizou apenas uma eira, no lugar do Norte essa situação voltou a repetir-se.

Tudo se passa pois como se, na periferia, o funcionamento das relações sociais invertesse de forma sistemática o que se passa na zona central (cf. mapa 6). Cada um destes lugares está no fundo sujeito aos mesmos constrangimentos que operam na zona central: e a aparente aceitação do convite ao ensimesmamento que lhes é daí dirigido é desmentido, num segundo momento, pela importância que neles assume uma relação privilegiada com 


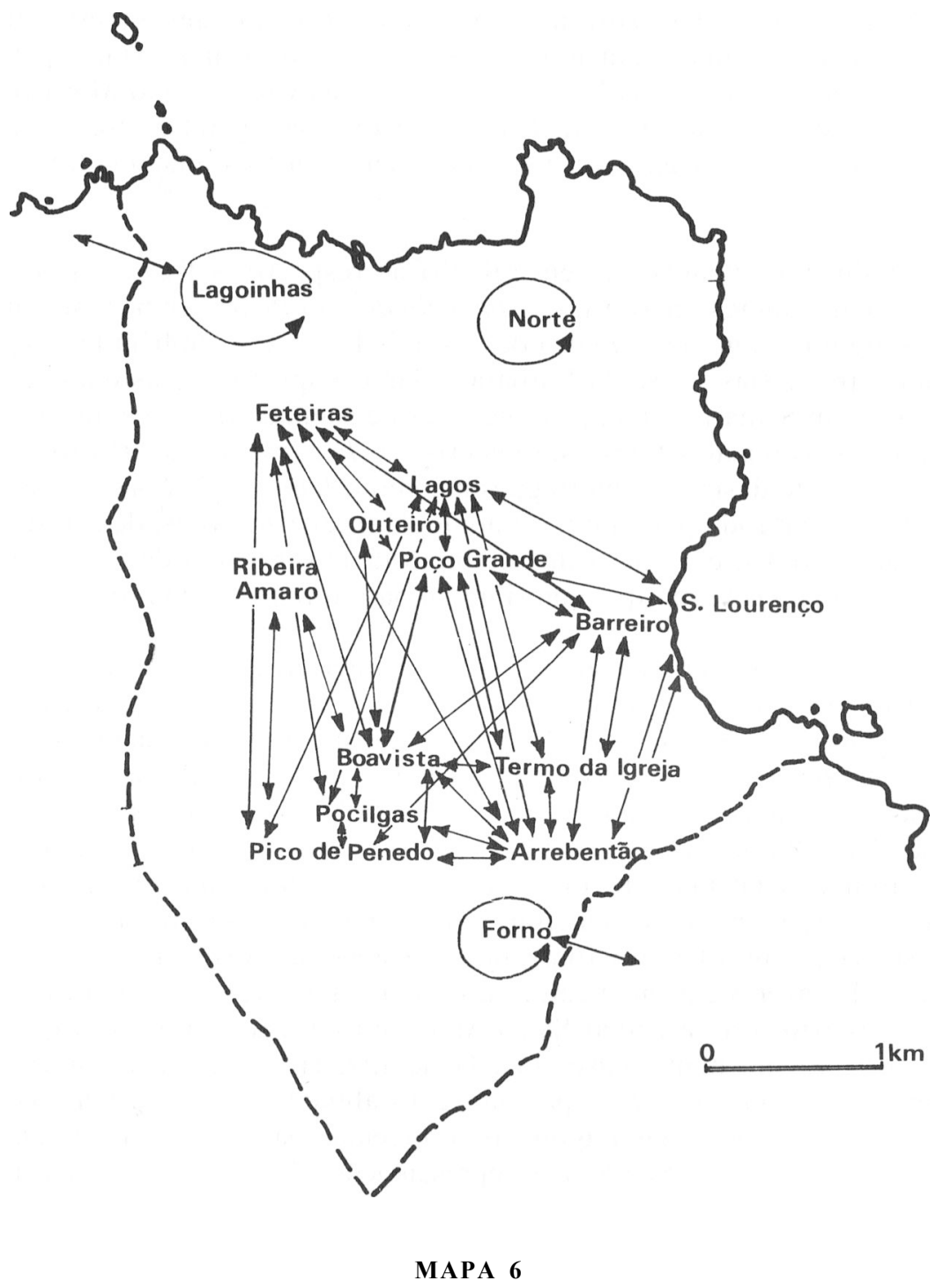

Configuração do sistema social no centro e na periferia

as freguesias vizinhas. Fazendo-o, tanto as Lagoinhas como o Forno, introduzem o elemento de exterioridade indispensável à sua definição como unidades sociais em relação.

É no quadro desta configuração que o Império de São Pedro pode ser, num primeiro momento, vantajosamente pensado. Não como um desmentido 
da lógica global dos Impérios, mas como uma expressão dessa mesma lógica nas condições de funcionamento da organização social nos lugares periféricos. Por seu intermédio, os lugares do Forno e da Cruz de São Mor celebravam não apenas a sua especificidade no quadro mais geral da freguesia respectiva, como reforçavam os laços «sui generis» que os uniam entre si.

Unindo dois lugares que em relação às respectivas freguesias exibem uma comum condição periférica, o Império de São Pedro, embora se comece por configurar como um Império desses dois lugares, é também um Império das duas freguesias - Santa Bárbara e Santo Espírito - nas quais eles se integram. Em Santa Bárbara, pelo menos, este segundo traço é evidente: apesar das suas carcacterísticas «sui-generis», o Império de São Pedro - significativamente designado na freguesia como o Império do Forno - é apresentado com fazendo parte do património da freguesia. Aliás, de acordo com testemunhos orais, era relativamente importante o número de casas doutros lugares que não o Forno que contribuíam para o Império com pães de mesa e roscas.

Marcado desta forma com um selo de interioridade, o lugar do Forno contrasta, neste aspecto, com o estatuto de exterioridade que, pelo contrário, rodeia o lugar das Lagoinhas. "Lagoinhas é Espanha», costuma dizer-se em Santa Bárbara. E também nas Lagoinhas que são localizadas as histórias de pessoas que viram «a verdadeira terra de Santa Maria». Conta-se que a actual ilha de Santa Maria não é senão um vestígio de uma terra muito maior, entretanto afundada no mar, devido a um encantamento. Em dias enevoados, afirma-se que se pode ver emergir, por momentos, essa «terra encantada», onde se vêem bois a lavrar e roupa branca estendida. Nesses momentos, seria possível desfazer o encantamento, mas ninguém até agora o fez porque, dizse, ou desapareceria a actual Santa Maria ou desapareceria outra qualquer ilha açoriana com nome masculino. Generalizadamente, estas histórias são referenciadas como tendo-se passado com alguém das Lagoinhas ou com alguém que passava pelas Lagoinhas. Projectada para o exterior do sistema social por intermédio deste tipo de representações, Lagoinhas e os seus moradores excluem-se ainda dele pela sua suposta relutância em frequentarem a missa dominical, principal polo de agregação regular de toda a freguesia. Dessa acusação, defendem-se eles dizendo que, como as igrejas de Santa Bárbara e de São Pedro ficam igualmente longe, umas vezes vão à missa num lado, outras noutro.

É exactamente essa espécie de atracção simultânea por duas freguesias, em tudo semelhante àquela que esta última frase revela a propósito das Lagoinhas, que se reencontra no Forno. Só que aí essa atitude não é tão fortemente condenada e, diferentemente das Lagoinhas e da sua quase exclusão do círculo da freguesia, o Forno é pensado num registo mais interior (cf. mapa 7). 


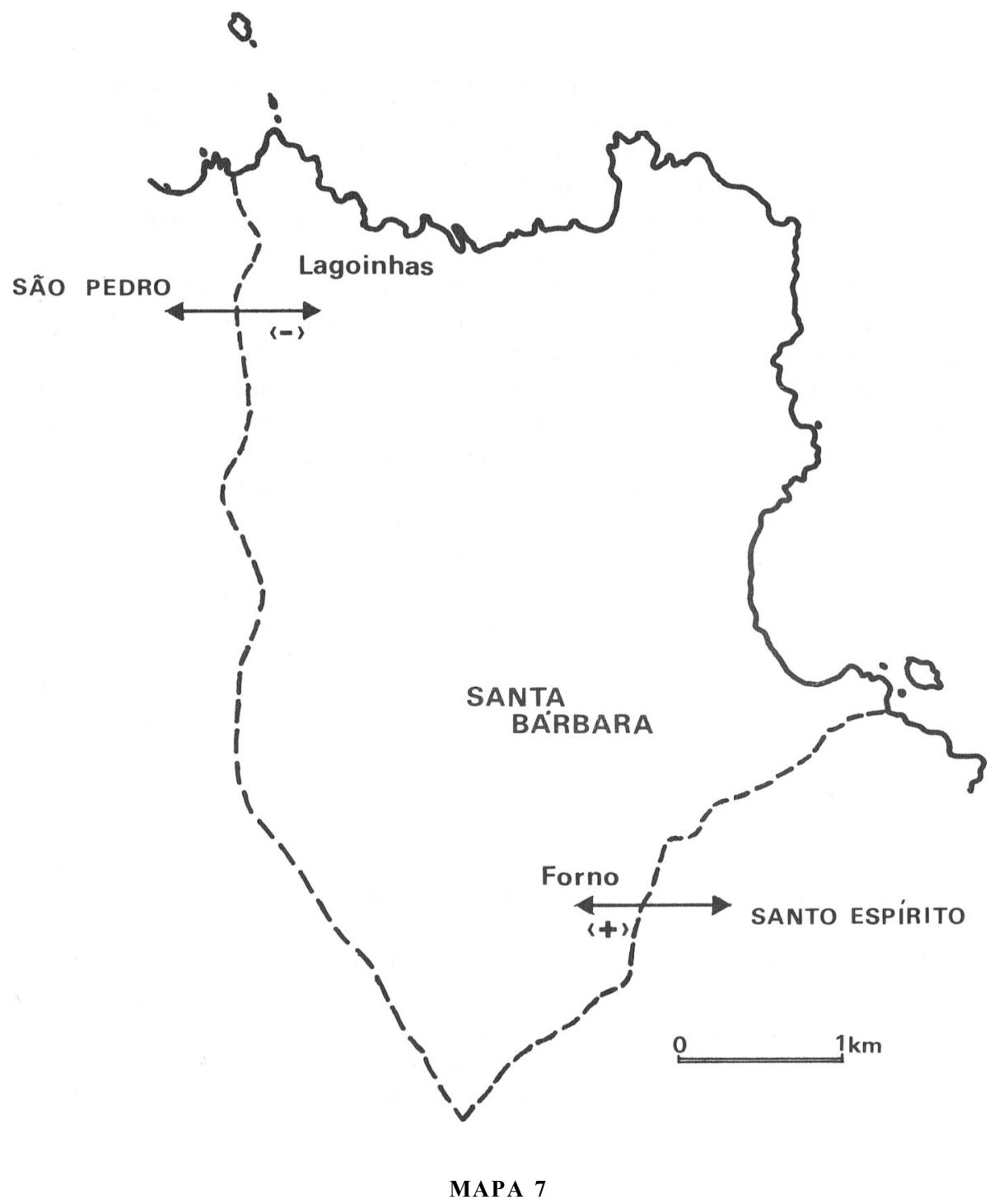

Lugares periféricos: Lagoinhas vs. Forno

A explicação deste facto exige um retorno à natureza das relações que Santa Bárbara mantém com as restantes freguesias da ilha, cujo ponto de partida pode ser de novo fornecido pelo ditado que citámos atrás:

«Os da Serra são labregos

Os da Vila cidadães 
D'Almagreira são lapujas

de São Pedro lambuzães.»

Nele, o epíteto de labregos aplica-se tanto aos habitantes de Santa Bárbara como aos de Santo Espírito. O facto começa por exprimir o contraste que, em Santa Maria, separa as três freguesias situadas a oeste das duas freguesias situadas na parte leste da ilha, as freguesias da Serra. Esse contraste diz respeito, em primeiro lugar, às características geográficas e humanas que distinguem entre si essas duas áreas, como tivemos ocasião de evocar no início do Capítulo 1. Mas exprime-se ainda noutros registos. Vimos atrás que é entre os Impérios das freguesias da parte oeste da ilha e os Impérios das freguesias da Serra que as diferenças são mais pronunciadas. A essa forte diferenciação entre a Serra e a Vila, corresponde inversamente uma maior similitude entre Santa Bárbara e Santo Espírito. Essa maior similitude faz-se entretanto acompanhar de uma rivalidade particularmente pronunciada entre ambas as freguesias, que não deixa de apresentar algumas similitudes com as «rivalidades preferenciais» entre aldeias referidas por Pitt-Rivers a propósito da Andaluzia (Pitt-Rivers, 1971: 11). Em Santa Bárbara são frequentemente rememoradas algumas das facetas mais relevantes dessa rivalidade preferencial. No passado, era usual os rapazes de Santa Bárbara «correrem à pedrada» qualquer rapaz de Santo Espírito que mostrasse intenções de namoro em relação a uma rapariga da freguesia - e vice-versa. No retorno da Festa do Senhor dos Passos - que se realizava na Vila, no decurso da Semana Santa - os habitantes de ambas as freguesias faziam habitualmente em conjunto o caminho de regresso: «mas em chegando aos Picos, arranjavam sempre maneira de pelejarem uns com os outros». Na actualidade, embora com formas mais atenuadas, essa rivalidade preferencial entre as duas freguesias mantém-se viva, como tivemos ocasião de verificar na análise a que procedemos dos Impérios.

Tudo se passa como se, unidas por um grande número de traços em comum, cada uma das freguesias se configurasse como o parceiro ideal para que a outra se possa definir como tal, por contraste com uma unidade cujas semelhanças devem ser permanentemente contraditadas por traços de separação que a inter-rivalidade mútua se encarrega de introduzir. Cada freguesia convida a outra a definir-se por relação a ela, a meio caminho entre um certo número de semelhanças e contrastes que possibilitem o confronto sem os riscos da dissolução mútua. Os contornos de natureza «dualista» desta forma de representar a organização social são $\operatorname{claros}^{1}$ e é justamente nesse quadro que

\footnotetext{
${ }^{1}$ Lévi-Strauss definiu o dualismo como «um sistema no qual os membros da comunidade - tribo ou aldeia - são repartidos em duas divisões que mantêm relações complexas indo da hostilidade declarada até a uma intimidade muito estreita e onde se encontram habitualmente associadas diversas formas de rivalidade e de cooperação» (Lévi-Strauss, 1971: 80). Mas este tipo de relações encontra-se frequentemente entre agrupamentos sociais que não constituem
} 
o Império de São Pedro deve ser também analisado. Unindo dois lugares de fonteira entre as duas freguesias ele funciona como uma espécie de ponto de sutura desse sistema «dualista» que se estabelece entre ambas. Daí o envolvimento que, pelo menos em Santa Bárbara, a freguesia experimenta em relação a ele. Pelo contrário o selo de exterioridade que pesa sobre as Lagoinhas está indissociavelmente ligado à sua situação periférica não só em relação à freguesia de Santa Bárbara, mas também em relação ao sistema de tipo «dualista» em que esta, em conjunto com a freguesia de Santo Espírito, se integra. É porque faz fronteira com uma freguesia da metade ocidental da ilha que Lagoinhas se vê como que projectada para fora do sistema social.

formalmente duas metades de uma determinada unidade social. É o caso — bem conhecido dos antropólogos — dos Nuer e dos Dinka. Embora formem duas «tribos» autónomas, EvansPritchard referiu-se-lhe como «segmentos no interior de uma estrutura comum à semelhança dos segmentos de uma mesma tribo Nuer» (Evans - Pritchard, 1940: 125). Assim, «a estrutura política dos Nuer só pode ser compreendida em relação aos seus vizinhos com os quais eles formam um único sistema político» (id., ibid.). Este tipo de relações pode ser encarado como uma «transformação» da organização clássica dualista: o grupo A define-se por oposição ao grupo B da mesma maneira que a metade A se define por oposição à metade B. É neste sentido que é possível utilizar, a propósito das relações entre Santa Bárbara e Santo Espírito, a expressão «dualismo». 
CAPÍTULO 6

O TEMPO DOS IMPÉRIOS 
Constituindo, como vimos, a designação reservada ao período tradicionalmente consagrado à realização dos festejos, a expressão tempo do Impérios transporta consigo um convite: o de examinar o vínculo existente entre o ritual e as formas de representação e conceptualização do tempo que lhe estão subjacentes.

Esse vínculo começa por ter uma dimensão sazonal muito forte. De facto, estendendo-se tradicionalmente ao longo do período que medeia entre o domingo de Páscoa e o domingo da Trindade o tempo dos Impérios coincide, de um ponto de vista sazonal, com o início da Primavera. De um período do ano dominado pelo adormecimento da natureza e pela exaustão da fertilidade vegetal e animal, a sociedade acede então a uma fase do ciclo anual marcada pelo renascimento da natureza e pela regeneração da fertilidade.

É justamente à luz deste enquadramento sazonal que pode ser entendido o relevo que na estrutura dos Impérios têm um conjunto de motivos relacionados com a vegetação em que avultam decorações de vário tipo, baseadas em plantas e flores próprias da época: giestas, alecrim, bordões de São José, novelãs, malmequeres, etc... Essa presença da vegetação exprime-se em primeiro lugar em associação com o próprio cenário físico em que se desenrolam os Impérios. Assim, durante a fase preliminar do Império, a porta da casa do imperador é enfeitada com giestas. A decoração tradicional do altar onde é instalada a Coroa e o próprio quarto do Espirito Santo possuem também uma importante componente floral, sendo o altar do Espirito Santo recorrentemente referido nos cantares da folia como jardim. Este elemento vegetal reencontra-se também em dia de Império. A entrada da porta da copeira - à semelhança da porta da casa do imperador - é ornamentada com giestas, e o pequeno altar situado no teatro onde, depois da coroação, é instalada a Coroa, é também decorado com flores. Esta associação dos Impérios à vegetação reencontra-se ainda nas insígnias do imperador, dos pagens da mesa e dos ajudantes grados. Os fruteiros que eles usam no braço esquerdo têm na sua origem uma decoração floral. Da mesma maneira, em dia de Império, as 
varas dos ajudantes grados são também enfloradas. Mas é sobretudo em associação com o alimento que é mais importante esta associação dos Impérios à vegetação. Antes de serem abatidas, as reses são geralmente enfeitadas, em volta dos chifres, com novelãs e malmequeres. Por seu turno, quer as escaldadas quer os pães de trigo distribuídos no decurso da irmandade são encimados por um pequeno ramo de alecrim. É entretanto em torno dos pães de mesa e roscas que, como vimos, é mais expressiva esta associação entre o alimento e a vegetação. Estes são profusa e artisticamente decorados com bordões de São José, novelãs, malmequeres, etc... Justamente por essa razão, uma das expressões mais utilizadas para os designar, quer nos cânticos da folia, quer inclusivamente no discurso corrente é o de flor, ou, ainda, flor do Espirito Santo. Contribuindo para ligar os Impérios a ideias de renascimento da natureza próprias da Primavera, esta recorrente associação dos Impérios à vegetação desempenha também um papel estético muito importante. Deste ponto de vista, deve ser realçada a particular relevância do cortejo que leva o Império para a copeira. Reservando um importante papel ao transporte cerimonial dos pães de mesa e roscas para a ermida ou igreja em que tem lugar o dia de Império, ele constitui-se de facto na melhor expressão estética desta associação entre os Impérios e a vegetação.

Marcados com sinais do renascimento da natureza, os alimentos cerimoniais dos Impérios corporizam também de forma emblemática o retorno da fertilidade que a Primavera assinala. O papel que nos Impérios têm os alimentos cerimoniais feitos à base de carne de rês - com relevo para as Sopas do Espírito Santo - liga-se directamente ao «pico» que conhece então depois do período de recessão coincidente com o Outono e o Inverno, marcado pela escassez de erva nos pastos - a criação de gado. O relevo da massa sovada - em cuja preparação intervêm quantidades extremamente importantes de ovos - reflecte um padrão idêntico: é na Primavera que a abundância de ovos é maior.

Dada esta sua ligação a ideias de renascimento da natureza e de regeneração da fertilidade próprias da Primavera, não é de estranhar que os Impérios se constituam por fim numa espécie de garante da preservação de algumas das principais produções agrícolas da freguesia. De facto, como vimos, no quadro dos peditórios de géneros - trigo, vinho, milho - que ocorrem por ocasião das debulhas, das vindimas e das desfolhas, a imposição do ceptro possuía um valor mágico de protecção dessas produções.

\section{II}

Esta referência sazonal a que os Impérios obedecem é reforçada pela significação ampla dada à expressão tempo dos Impérios. Esta, além do signifi- 
cado restrito de período de tempo consagrado aos Impérios, evoca ainda, nas verbalizações das pessoas, uma fase claramente demarcada do ciclo anual, caracterizada por um conjunto de actividades unidas por um comum denominador sazonal: arrumação, limpeza e caiação das casas, início dos trabalhos de acompanhamento do crescimento das principais produções agrícolas, regresso do gado às pastagens, etc...

Simultaneamente, neste sentido amplo que acabámos de referir, a expressão tempo dos Impérios inscreve-se num eixo sintagmático que pressupõe a existência ao longo do ano de um conjunto de outros tempos também eles individualizados por referência a um conjunto de actividades específicas. Alguns desses tempos são designados de acordo com um registo que nos remete para o calendário agrícola: tempo dos trigos - aplicado ao período do ano coincidente com a ceifa e a debulha do trigo (fins de Julho/ princípio de Agosto) - tempo dos milhos - que designa o período em que se realiza a apanha e a desfolha do milho (Setembro/ Outubro) - etc... Mas outras remetem para o registo do calendário cerimonial: tempo da Quaresma, mês das almas - que se reporta ao mês de Novembro, que abre com as comemorações dos Finados e Todos-os-Santos - mês da Festa - que, aplicando-se em primeiro lugar ao mês em que se realiza a Festa de Santa Bárbara, designa também o período em que recaem as matações, etc...

Este último registo é particularmente importante para a análise das cerimónias cíclicas. De facto, como diversos antropólogos têm sublinhado, as cerimónias cíclicas devem ser encaradas como unidades de um sistema mais vasto, no interior do qual cada uma delas ganha o seu sentido.

Implicitamente presente no esforço de sistematização a que Van Gennep procede no seu «Manuel de Folklore Français Contemporain» (1947), esta perspectiva encontra-se mais explicitamente argumentada na obra que Propp consagrou à análise das festas agrárias russas (1978). Demarcando-se de estudos que prescindem desta dimensão das cerimónias cíclicas, Propp sublinha que «uma festa particular (...) só pode ser correctamente compreendida quando se estuda todo o ciclo anual das festas» (1978: 42). E também numa direcção similar que se inscreve a reflexão de E. Leach (1961: 124-143). Depois de chamar a atenção para a importância das festas na construção do tempo, Leach sublinha que «para apreciarmos de forma nítida o modo como a festividade serve para ordenar o tempo, devemos considerar o sistema como um todo e não apenas festas isoladas» (id.: 135). Alguns dos exemplos são retirados do calendário cerimonial europeu: «os 40 dias entre o Carnaval (a TerçaFeira de Entrudo) e a Páscoa são contrabalançados pelos 40 dias entre a Páscoa e a Ascensão» (id., ibid.), etc...

Foi entretanto com o estruturalismo que esta perspectiva se impôs de forma mais decisiva. Lévi-Strauss, nalgumas passagens das suas «Mythologiques», sugere a possibilidade de aplicar ao ritual de uma forma geral e às cerimónias cíclicas em particular um modelo inspirado na análise estrutural do mito, onde justamente o que conta não é cada elemento encarado 
AS FESTAS DO ESPÍRITO SANTOS NOS AÇORES

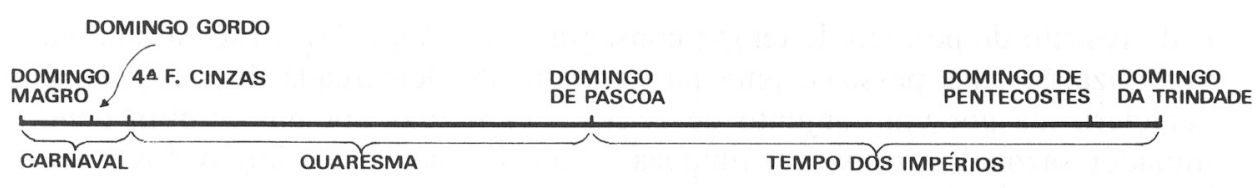

FIGURA 5

Carnaval, Quaresma e Impérios

isoladamente mas a teia de relações - de oposição, de complementariedade, de simetria, de inversão - que une entre si os diferentes elementos e por referência à qual cada um recebe o seu significado. As páginas que este autor dedicou ao exame dos rituais europeus ligados ao Carnaval, à Quaresma e à Páscoa constituem uma demonstração das virtualidades dessa grelha na análise das cerimónias cíclicas em contexto europeu (cf., em particular, Lévi-Strauss, 1967: 347-363).

Um tratamento mais argumentado desta grelha analítica encontra-se em dois textos expressamente consagrados ao problema por Pierre Smith (Smith, R, 1979; 1981). No primeiro desses textos, P. Smith chama a atenção para o facto de as cerimónias cíclicas formarem entre si um sistema: «qualquer rito está ligado a uma circunstância que determina a sua ocorrência e estas circunstâncias fazem, elas próprias, parte de séries. Os diferentes ritos associados a circunstâncias que dependem de uma mesma série tendem a formar um sistema, ou seja, eles respondem-se, opõem-se, completam-se ou repetem-se de uma forma que, sob todos os aspectos, é mais evidente do que no caso dos ritos ligados a circunstâncias que dependem de séries diferentes» (Smith, R, 1979: 145). No caso das cerimónias cíclicas as circunstâncias a que elas responderiam seriam de tipo periódico e elas formariam «sistema segundo um eixo sintagmático; cada rito da série será necessariamente precedido e seguido por um outro, segundo uma ordem bem determinada que se repetirá a cada recorrência do ciclo» (id., ibid.). Dois anos mais tarde, num artigo consagrado ao exame da noção de «festa» (Smith, P., 1981), P. Smith voltaria a argumentar em favor desta perspectiva. «As festas — sublinha ele - definem-se primariamente por oposição a outros momentos do sistema ritual que determinam a sua ocorrência» (Smith, R, 1981: 219). Os exemplos são mais uma vez retirados do ciclo cerimonial nas sociedades europeias: «assim, a Terça-Feira Gorda opõe-se à Quarta-Feira de Cinzas, o dia de Páscoa à Sexta-Feira Santa, etc...» (id., ibid.).

E justamente a partir deste quadro interpretativo que se torna possível começar por analisar aquele que considerámos ser um dos aspectos mais relevantes dos Impérios: a sua ligação a ideias de reiteração das relações sociais. 
De facto, desenvolvendo-se tradicionalmente ao longo do período compreendido entre o domingo de Páscoa e os domingos de Pentecostes e da Trindade, os Impérios sobrevêm não apenas na sequência imediata de dois «ciclos» cerimoniais particularmente importantes para o imaginário local o Carnaval e a Quaresma (cf. figura 5) - como é justamente no interior desse quadro cerimonial alargado que eles podem começar por ser interpretados, como uma peça essencial de um discurso que relaciona entre si tempo e estrutura social.

Passemos rapidamente em revista alguns aspectos etnográficos mais relevantes desses dois «ciclos» cerimoniais. Tal como na tradição geral europeia e portuguesa, o Carnaval em Santa Bárbara pode ser visto como um período de excesso e licenciosidade autorizados. Essas suas características expressam-se, em primeiro lugar, na preparação e no consumo abundante de mal assadas - feitas à base de farinha frita em gordura de porco - que marcam em plano de relevo a quadra. Simultaneamente, os festejos dão lugar - em Domingo Magro, em Domingo Gordo e na Terça-feira de Carnaval - à aparição de personagens mascarados. Conhecidos sob a designação de velhos, esses personagens percorrem em bandos a freguesia, visitando as casas e entregando-se a todo o tipo de excessos, com particular incidência no «roubo», simulado ou real, das mal assadas e de outros alimentos que apanham à mão em cada casa. Mais recentemente, generalizou-se também na freguesia o costume das danças de Carnaval: formam-se um ou mais ranchos de rapazes e raparigas que, geralmente no Domingo Gordo e na Terça Feira de Carnaval, exibem danças especialmente montadas para o efeito. Os cantares que acompanham essas danças assumem frequentemente um marcado tom jocoso, designadamente por intermédio da passagem em revista crítica de alguns acontecimentos e personagens mais marcantes da vida da freguesia. No seu quadro, os mascarados desempenham um papel importante, interrompendo as danças com gritos de efeito cómico, «provocando» os assistentes, «forçando-os» a fazerem contribuições monetárias, etc...

Seguindo-se ao Carnaval, a Quaresma surge tradicionalmente associada a ideias de contenção e severidade contrastantes com os excessos e a licenciosidade carnavalescas. Em contraponto ao consumo obrigatório e abundante de alimentos gordos, generalizam-se então os jejuns e abstinências alimentares, com particular realce para aquelas que têm lugar em todas as $6{ }^{\text {as }}$ Feiras de cada uma das sete semanas da Quaresma e ainda na 6. ${ }^{\mathrm{a}}$ Feira e Sábado Santos. Em contraste com a licenciosidade carnavalesca a vida ritual é então dominada por uma espécie de "tristeza obrigatória». Centrada na evocação da morte de Cristo, a Quaresma constitui de facto um período do ciclo cerimonial anual predominantemente estruturado em torno de um marcado despojamento litúrgico, por um lado, e da penitência e da oração, por outro. O tom começa por ser dado na $4 .^{a}$ Feira de Cinzas. Nesse dia, através da cerimónia da imposição das Cinzas, a Igreja relembra aos fiéis a sua condição mortal: «lembra-te que és pó / e em pó te hás-de tornar». A liturgia coloca-se a partir daí sob 
o signo de uma contenção - expressa, por exemplo, na cor violeta dos paramentos sacerdotais ou na supressão de certas orações e cânticos da missa mais vinculados a ideias de vida - que atingirá o seu ponto culminante no decurso da $6 .^{a}$ Feira e Sábado Santos. A missa não é então celebrada e, na igreja, as imagens eram tapadas, as luzes extintas, os sinos silenciados, sendo substituídos, até há cerca de dez anos atrás, pelos chamados instrumentos das trevas ${ }^{l}$. E também nesses dias que a penitência e a oração ganham a sua expressão mais enfática. Têm então lugar na igreja paroquial algumas vias-sacras e até há cerca de 30/40 anos era ainda usual realizar-se num desses dias a procissão do Senhor dos Passos - que percorria o Termo da Igreja - caracterizada justamente por um tom penitencial fortemente marcado.

Unidos por laços de contiguidade temporal, os dois «ciclos» cerimoniais que acabámos de passar em revista mantêm com os Impérios relações privilegiadas de oposição e complementariedade. Pensadas localmente sobretudo por referência ao alimento ou ainda em termos da ambiência subjectiva que cada um desses «ciclos» evoca - folia / tristeza / alegria -, essas relações estendem-se também ao plano sociológico. Antecedendo imediatamente os Impérios, o Carnaval e a Quaresma são de facto caracterizados por uma orientação sociológica contrastante com a dos Impérios. Enquanto estes nos apareceram privilegiadamente ligados a ideias de reiteração dos principais círculos de relacionamento social, o Carnaval e a Quaresma tendem a identificar-se inversamente com ideias de desestruturação e latência das relações sociais.

A ligação do Carnaval a ideias de desestruturação das relações sociais transparece antes do mais, no ambiente geral de excesso e licenciosidade que o caracteriza. Por seu intermédio, é a ordem social no seu conjunto que é momentaneamente posta em questão. Alguns dos motivos mais específicos em que se desdobram os festejos carnavalescos remetem também para o mesmo horizonte simbólico. Assim, a circulação do alimento aparece articulada, como vimos, com uma momentânea subversão das regras de etiqueta e reciprocidade que rodeiam a dádiva alimentar: em vez de trocados, os alimentos são exigidos ou roubados. O papel dos personagens mascarados, por seu turno, liga-se directamente ao tema da ocultação da identidade. Por seu intermédio, o Carnaval define-se como um período de suspensão e confusão do jogo de identidades sobre que assenta a vida social. Quanto às danças de Carnaval, elas articulam-se também, pelo modo como possibilitam a crítica e a troça públicas em níveis usualmente não admitidos, com uma momentânea suspensão das regras que presidem ao relacionamento social.

Precedida por este período de desestruturação das relações sociais, a Quaresma surge pelo seu lado associada a dispositivos simbólicos que tendem a conotá-la com ideias de margem ou liminaridade das relações sociais, para empregar as expressões clássicas de Van Gennep (1909). Período

\footnotetext{
${ }^{1}$ Em Santa Bárbara existe ainda na sacristia um desses instrumentos, uma matraca.
} 
de oração e de penitência, de supressão da festa, de jejum e de abstinência, a Quaresma, centrada na evocação da morte da divindade, como que convida a sociedade a um período de luto no decurso do qual a vida social deve ela própria rarefazer-se. De facto, em consequência da especial orientação da sua espiritualidade para as «coisas de Deus», a vida social no decurso da Quaresma tende a aparecer associada - em particular na sua versão pré-conciliar - a ideias de contenção, como salientam os liturgistas católicos quando a apresentam como um período de «afastamento e separação do mundo» (Béranger, 1949: 179) ou de «recolhimento unânime» (Spiritualité Pascale, 1957: 55). Nessa época do ano, diziam-me a propósito em Santa Bárbara, «cada um parece que está mais em si». Este estado de latência - de acordo com a própria organização interna da Quaresma - atinge uma expressão particularmente significativa na Semana Santa e, em especial, na 6. ${ }^{a}$ Feira e Sábado Santos. O Triduum faz-se de facto acompanhar «idealmente» da suspensão de toda a actividade «profana», dobrada em muitos casos, por tradições propriamente populares que sublinham essas ideias de liminaridade ${ }^{1}$.

E justamente por referência a esta latência social quaresmal - relativamente à qual o Carnaval, com a desestruturação das relações sociais a que se entrega, opera como prólogo - que pode começar por ser entendido o trabalho sociológico que caracteriza os Impérios. Sucessivamente submetidas a um processo de desorganização e latência, as relações sociais conhecem então um movimento de reorganização e renovação.

Desestruturação e latência devem ser nessa medida encaradas como expressões provisórias de uma lógica que é a da reiteração cíclica das relações sociais. Este aspecto foi fortemente enfatizado por M. Bakhtine que, na sua obra clássica sobre o Carnaval (1970), pôs em evidência o modo com a ruptura, a inversão e a transgressão próprias da linguagem carnavalesca devem ser interpretadas como dispositivos simbólicos ao serviço de ideias de regeneração periódica da ordem social. E de acordo com pressupostos similares que podem ser encaradas as ideias de latência e margem próprias da Quaresma. Assim como no plano litúrgico a evocação da morte da divindade não é senão um preliminar indispensável à comemoração da sua ressurreição, também no plano sociológico a latência das relações sociais prepara a sua renovação. Citando Bloch e Parry, a morte deve também aqui ser vista como «um acto de regeneração universal que renova o tempo» (1987: 15).

\footnotetext{
${ }^{1}$ Leite de Vasconcelos (1982: 217 e 218) refere por exemplo entre essas tradições, a interdição, durante a $6{ }^{\mathrm{a}}$ Feira Santa, de actividades como cozinhar, fiar, cozer, lavar a roupa, etc... No caso de Santa Bárbara, algumas dessas interdições reencontram-se mas em articulação com a $4 .^{a}$ feira da Semana Santa - a $4 .{ }^{a}$ feira de trevas, como é localmente designada.
} 
É no quadro desta perspectiva que pode ser examinado o modo como o Carnaval e a Quaresma, ao mesmo tempo que surgem associados, no plano sociológico, a ideias de desestruturação e margem próprias de um período de fim de ciclo, prenunciam, no plano sazonal, ideias de renascimento da natureza e de regeneração da fertilidade próprias do início de um novo ciclo natural. Assim, no Carnaval, a circulação do alimento, ao mesmo tempo que remete para ideias de desestruturação social antecipa também as ideias de abundância alimentar próprias dos Impérios e, na Quaresma, a componente vegetal que, também em Santa Bárbara, caracteriza o Domingo de Ramos, opera como um prólogo às ideias de renascimento da natureza a que os Impérios aparecem vinculados.

Conotados na sua adscrição sazonal com ideias de renascimento da natureza e de regeneração da fertilidade, os Impérios recebem pois, em virtude da sua colocação no interior do ciclo cerimonial anual, um significado suplementar de renovação cíclica das relações sociais.

É no interior deste quadro que pode ser explicado o peso que na sua sequência têm um conjunto de desempenhos assegurados por crianças ou jovens. Trata-se de, com recurso ao código etário, sublinhar a estreita relação existente entre o ritual e as ideias de regeneração da ordem natural e social nele inscritas. Este aspecto é particularmente importante, no quadro mais geral de Santa Maria, nos Impérios que se realizam nas freguesias da metade oeste da ilha. De facto, como tivemos ocasião de verificar, a coroação incide aí sobre o chamado menino da mesa, uma criança de quatro a oito anos de idade.

Em Santa Bárbara esta solução é exclusivamente utilizada no quadro dos Impérios secos. De facto, tanto no Império de São João como no de São Pedro, era sobre uma criança ou sobre um jovem que incidia a coroação. Para além disso, como tivemos oportunidade de verificar, o Império de São João definia-se também no passado pela sua ligação ao grupo de idade dos rapazes. Mas, embora sob formas menos directas, os Impérios propriamente ditos acolhem também ideias similares. É a essa luz que pode ser entendido o relevo que no séquito do imperador têm não apenas os pagens da mesa, mas também os briadores, escolhidos respectivamente entre crianças de quatro a oito anos de idade e entre os rapazes solteiros da freguesia. Simultaneamente, pode-se também falar de uma associação privilegiada das crianças e rapazes à esfera da circulação do alimento, tanto mais significativa quanto é sobre o alimento que assenta o trabalho de renovação das relações sociais a que os Impérios se entregam. De facto, um certo número das distribuições alimentares 
dos Impérios encontram-se a cargo destes grupos etários. É esse o caso das distribuições porta-a-porta de Sopas do Espírito Santo, asseguradas, como vimos, por crianças e rapazes de idades geralmente compreendidas entre os seis e os doze anos. Dentro da mesma ordem de ideias, devem ser destacadas as responsabilidades que os briadores têm também nessa esfera. Como vimos, as corridas de biscoitos de orelha e vinho que têm lugar no decurso das alumiações estão a seu cargo e, no passado, eram também eles que asseguravam a distribuição porta-a-porta da irmandade. Finalmente, em dia de Império, são também os briadores que conduzem as corridas de massa sovada e de vinho que se realizam no exterior do recinto.

A sequência ritual formada pelo Carnaval, Quaresma e Impérios mantém uma relação estreita com os ritmos e temporalidades de natureza sociológica que estruturam o ciclo anual no seu conjunto. Situados no termo do Inverno e associados a ideias de desestruturação e latência das relações sociais, o Carnaval e a Quaresma põem fim a uma fase do ciclo anual, coincidente com o Outono e o Inverno, caracterizada pela gradual dominância de ideias de desaceleração e contenção das relações sociais.

Esta tendência pode começar por ser surpreendida em torno do calendário agrícola (cf. quadro 20). Este é marcado, antes do mais por uma desaceleração da actividade produtiva nos campos. Os trabalhos tornam-se mais espaçados e relacionam-se sobretudo com a preparação prévia das terras e com as sementeiras. O mês de Outubro é dedicado à primeira lavra - seguida de gradagem - das terras destinadas ao trigo. Ainda no fim desse mês ou já no princípio de Novembro, inicia-se por seu turno, com os outonos, a preparação das terras destinadas ao milho e à batata. As terras são então semeadas com tremoço (ou fava); depois deste ter crescido, são de novo lavradas de modo a que o tremoço (ou a fava), enterrado no solo, possa funcionar como adubo natural. No decurso desse mês, realizam-se ainda a segunda e a terceira lavra das terras destinadas ao trigo que é semeado um mês depois, em Janeiro. Janeiro é também o mês em que são «estercadas» as terras destinadas à batata, que é plantada mais tarde entre Fevereiro e Março. Quanto às terras destinadas ao milho, são lavradas por duas vezes, respectivamente em Janeiro e Fevereiro, sendo depois semeadas entre princípios de Março e meio de Abril.

Simultaneamente a esta desaceleração do ritmo produtivo no exterior, ganham maior importância as actividades centradas no marco físico da casa. Entre elas destacam-se as desfolhas do milho e, sobretudo, a matação do porco. As desfolhas do milho têm lugar a partir de finais de Setembro e esten- 
AS FESTAS DO ESPÍRITO SANTOS NOS AÇORES

\begin{tabular}{|c|c|c|c|c|}
\hline MÊS & TRIGO & MILHO & BATATA & VINHA \\
\hline Outubro & $\begin{array}{l}\text { lavra/ } \\
\text { gradagem }\end{array}$ & desfolha & outonos & \\
\hline Novembro & $\begin{array}{l}\text { lavra } \\
\text { lavra }\end{array}$ & outonos & outonos & \\
\hline \multicolumn{5}{|l|}{ Dezembro } \\
\hline Janeiro & sementeira & lavra & estercar & \\
\hline Fevereiro & & lavra & plantar & \\
\hline Março & mondar & semear & plantar & podar \\
\hline Abril & mondar & semear & sachar & \\
\hline Maio & & sachar & & sulfatar \\
\hline & & & apanhar & \\
\hline Junho & & & apanhar & podar \\
\hline Julho & ceifas & & & $\begin{array}{l}\text { abrir/ } \\
\text { levantar }\end{array}$ \\
\hline Agosto & debulhas & & & \\
\hline Setembro & & & & $\begin{array}{l}\text { vindimas } \\
\text { vindimas }\end{array}$ \\
\hline & & apanha & & \\
\hline
\end{tabular}

QUADRO 20

Organização do calendário agrícola anual em Santa Bárbara

dem-se por todo o mês de Outubro: realizam-se no palheiro ou numa das divisões da casa. A matação do porco recai por seu turno, como vimos, nos meses de Dezembro e Janeiro. Antes disso, porém, e desde finais de Setembro, o porco ocupava já o centro das preocupações de cada casa: é então que decorre o período da engorda, no decurso do qual a sua alimentação é substancialmente reforçada e melhorada. Outubro, Novembro e Dezembro são também os meses de apogeu das produções cultivadas nos terrenos situados nas imediações de cada casa, no respectivo casal: é nessa altura que se procede à apanha dos nabos, inhames e batata doce, que têm um peso muito grande na dieta alimentar dessa época do ano. As próprias reses, dado o facto de este ser o período do ano em que os pastos produzem menos erva, são também deslocadas para os currais ou pastos situados nas imediações de cada casa, onde é mais fácil alimentá-las ${ }^{1}$.

\footnotetext{
${ }^{1}$ No passado, esta orientação de cada casa para uma actividade eminentemente interior era ainda reforçada pela ligação preferencial desta época do ano a um certo número de outras actividades, entretanto caídas em desuso. Entre elas merece especial referência a fiação do linho e da lã, que dava lugar à organização de serões num grande número de casas.
} 
Esta tendência para a desaleração da actividade produtiva e para o seu refluxo para o espaço da casa possui importantes consequências sociológicas. As actividades agrícolas no exterior, além de menos intensas, possuem também um carácter marcadamente individualista, envolvendo sobretudo a mão de obra da própria unidade doméstica. O recurso ao trabalho exterior é de facto bastante raro e quando ocorre baseia-se sobretudo no jornal, utilizado designadamente para pagar o trabalho assegurado pelo tractor ou pela junta de bois no âmbito das lavras. As actividades centradas no espaço físico da casa envolvem também formas de cooperação sociologicamente limitadas, centradas sobretudo nos parentes mais chegados e nos vizinhos de perto. As desfolhas e a matação do porco são, a esse respeito, emblemáticas. As desfolhas, pelo seu lado, dão sobretudo lugar a trocas recíprocas de trabalho, de carácter restrito, entre vizinhos de perto. Quanto à matação do porco ela liga-se, como tivémos oportunidade de examinar, ao núcleo mais básico e íntimo de relacionamento social de cada casa. Isto é: ao mesmo tempo que as ocasiões de encontro e de relação se tornam mais escassas, o espectro sociológico por elas coberto tende a confinar-se a círculos sociais mais próximos.

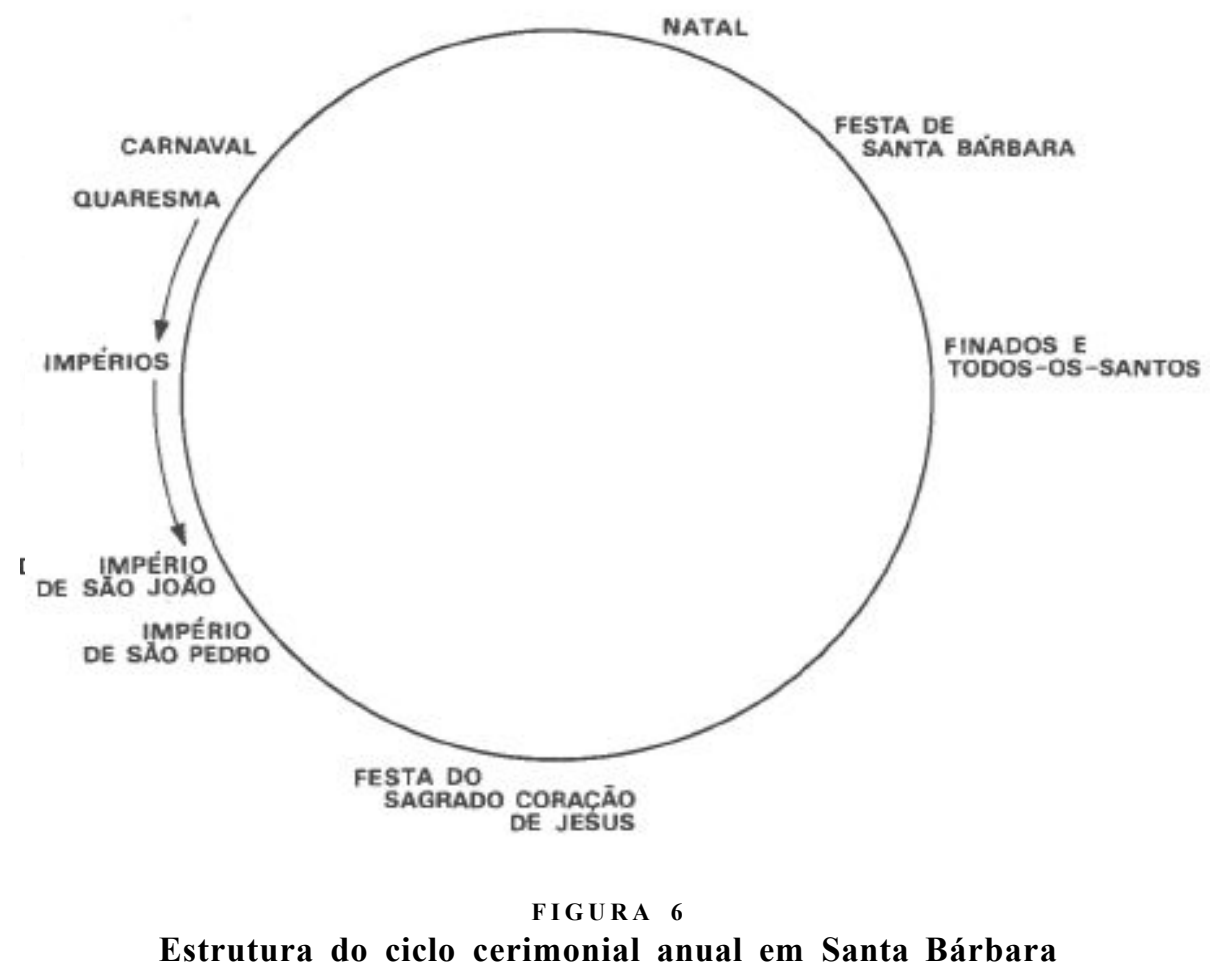


Presente ao nível do calendário agrícola, a ligação do Outono e do Inverno a formas de sociabilidade mais espaçadas e envolvendo sobretudo os círculos de relacionamento social mais próximos, reencontra-se ao nível do calendário cerimonial (cf. figura 6). De facto, as principais ocasiões cerimoniais deste período do ano aparecem predominantemente associadas a ideias de contracção das casas e das relações sociais.

Recebendo uma expressão particularmente enfática no tempo da Quaresma, estas ideias reencontram-se ainda nos Finados e Todos-os-Santos e no Natal, por intermédio da marcação essencialmente doméstica que caracteriza ambas as ocasiões. Os Finados e Todos-os-Santos, a 30 de Outubro e 1 de Novembro, constituem, pelo seu lado, uma celebração única dominada pela evocação dos mortos, ou das almas, que assinala, do ponto de vista do ciclo cerimonial, o início do Outono. Esta celebração possui, antes de mais, uma vertente religiosa. No dia 1 é celebrada uma missa pelos defuntos - antecedida pelo toque «a finados» dos sinos - seguida de uma romagem ao cemitério. Lá, depois de uma oração colectiva, cada família reúne-se de seguida junto das campas dos seus parentes falecidos, para uma oração de características mais pessoais. Estes actos têm uma participação importante das casas da freguesia e a sua sequência faz lembrar a dos funerais. No passado, era inclusivamente usual à semelhança daquilo que acontecia nos funerais - que certas casas procedessem, no termo da missa, à distribuição, junto de pessoas mais pobres, de brindeirinhos pelas almas. Simultaneamente a estas cerimónias religiosas esta data é sobretudo marcada pela realização de um pequeno ritual de características alimentares cuja orientação sociológica não poderia ser mais expressiva. No próprio dia 1 ou nas imediações desse dia, cada casa coze um certo número de maçarocas de milho, o chamado milho para os santos. Mas, em vez de, como noutras ocasiões cerimoniais, esse alimento circular entre casas, é sobretudo no quadro de cada unidade doméstica que ele é consumido ou partilhado ${ }^{1}$.

No Natal, reencontra-se uma orientação idêntica. Como vimos, é nessa ocasião que os padrinhos realizam a oferta cerimonial aos afilhados, integrada por um biscoito de orelha ou por um bolo talhado. Hoje em dia, a par dessa oferenda, generalizou-se também o hábito, sob a influência do modo de vida

${ }^{1}$ Os Finados e Todos-os-Santos ocupam, no calendário anual uma posição simétrica e inversa à dos Impérios. Assim, enquanto os Impérios, situados no início da Primavera e ligados ao tema vida, se colocam sob o signo de ideias de reiteração das relações sociais mais amplas, os Finados e Todos-os-Santos, situados no início do Outono e articulados em torno do tema da morte, inauguram uma fase do ciclo anual marcada por ideias de contracção das relações sociais. Não deixa a este respeito de ser interessante notar que, no plano culinário, enquanto os Impérios trabalham essas ideias com recurso a um cereal rico - o trigo - tratado - sob a forma de massa sovada - de um modo culinariamente elaborado, nos Finados e Todos-os-Santos se recorra inversamente a um cereal pobre - o milho - tratado sob uma forma que, do ponto de vista do tratamento usualmente reservado aos cereais, pode ser considerada como para-culinária - - o milho, em vez de ser cozinhado sob a forma de pão, é cozido em água ainda na maçaroca. 
urbana, de promover uma refeição melhorada. Mas, mais uma vez, as suas características são fundamentalmente familiares.

Situando-se no princípio da Primavera e associados a ideias de reiteração das relações sociais, os Impérios dão inversamente início a uma fase do ciclo anual em que se tornam gradualmente dominantes formas de sociabilidade mais intensa e envolvendo círculos de relacionamento social mais amplos e numerosos.

Mais uma vez esta orientação pode começar por ser surpreendida em torno da estruturação do calendário agrícola. De facto, em contraste com o carácter espaçado dos trabalhos agrícolas no decurso do Outono e do Inverno, a partir do início da Primavera, o ritmo da actividade agrícola torna-se mais exigente. Como vimos anteriormente, é a partir dessa altura que a criação de gado entra no seu «pico» anual. Simultaneamente, as actividades relacionadas com as principais produções agrícolas conhecem uma aceleração decisiva. Março e Abril são os meses da monda do trigo. Ainda em Abril a batata deve ser sachada e abarbada. Maio é por seu turno o mês dedicado às sachas do milho. É também nesse período que decorre uma parte importante dos trabalhos de conservação das vinhas: podas, sulfatagens, etc... Entretanto, nos campos, inicia-se o ciclo das colheitas. A parte final do mês de Maio e o mês de Junho dão lugar à apanha da batata. Julho por seu turno, é o mês da ceifa do trigo, à qual se segue, muitas vezes já no princípio de Agosto, a sua debulha. No final de Agosto e no início de Setembro realizam-se por sua vez as vindimas. E o ciclo das colheitas é encerrado, em Setembro, com a apanha e a desfolha do milho. Com elas, é também esta fase mais exigente do ciclo agrícola que chega ao seu termo.

Mais intensa, a actividade agrícola no decurso desta fase do ano requer também formas de cooperação relativamente assíduas e largas. Contrariamente ao «individualismo» prevalecente no Outono e no Inverno, a maior parte das tarefas passa a requerer trocas de mão ou a formação de grupos de trabalho mais extensos. Estes, podendo fazer a sua aparição no quadro dos diversos trabalhos de acompanhamento do crescimento da produção agrícola - mondas, sachas, trabalho nas vinhas, etc... - tornam-se norma no âmbito das colheitas. A apanha da batata faz-se em geral com grupos de trabalho de três a quatro homens. A ceifa do trigo dá também lugar à formação de grupos de trabalho que podem ir até cinco / seis indivíduos. E entretanto no quadro das debulhas de trigo que as formas de cooperação inter-casas assumem formas mais significativas. Estas dão lugar, por um lado, à formação de um dos mais extensos grupos de trabalho requeridos pela actividade agrícola, integrado por cerca de nove a dez indivíduos. Por outro lado, em seu torno estabelece-se uma espécie de reciprocidade generalizada entre as diferentes casas que debulham no mesmo dia. Sem que haja qualquer combinação prévia nesse sentido, membros dos vários grupos de trabalho das diferentes casas vão acorrendo de forma informal às debulhas de outras casas ${ }^{1}$.

\footnotetext{
${ }^{1}$ Esta espécie de reciprocidade generalizada que se estabelece nas debulhas pode ser exemplificada por intermédio do mapa de um dos dias da debulha de 1987.
} 
Devido a estes factores, as debulhas tendem a ser localmente encaradas como uma ocasião de natureza quase festiva, em que a cooperação e o convivio intervicinais atingem uma dimensão sociológica extremamente alargada. Embora os grupos requeridos para o efeito não sejam em geral tão amplos, e não existam formas de cooperação alargadas como as que acabámos de pôr em evidência, as vindimas participam também de uma atmosfera semelhante à das debulhas. De facto, a sua realização dá lugar, no fỉm do dia, a visitas às adegas, com provas de uvas e abundante circulação dos restos do vinho do ano anterior. Sobrevindo após estas duas ocasiões particularmente marcantes de um ponto de vista sociológico, a apanha do milho, situada no limiar do Outono, baseia-se já em formas mais limitadas de cooperação, antecipando de certa maneira essa espécie de «individualismo» que irá prevalecer durante o Outono e o Inverno.

Presente ao nível do calendário agrícola, a ligação da Primavera e do Verão a formas de sociabilidade mais frequentes e intensas e envolvendo círculos de relacionamento social mais amplos reflecte-se também na organização do calendário cerimonial. De facto, em contraste com a orientação essencialmente doméstica que caracteriza as principias ocasiões rituais ligadas ao Outono e ao Inverno, o calendário cerimonial no decurso da Primavera e do Verão fornece sucessivas ocasiões para o estreitamento de laços sociais mais amplos. Sobrevindo na sequência do tempo dos Impérios, o Império de São João prolonga, como vimos, as ideias de reiteração da unidade e da identi-

\begin{tabular}{ccc}
\hline CASA & $\begin{array}{c}\text { COMPOSIÇÃO DO } \\
\text { GRUPO DE TRABALHO }\end{array}$ & \multicolumn{1}{c}{ OUTRAS AJUDAS } \\
\hline 1 & 7 & 2 Casa 4 \\
2 & 4 & 2 Casa $3+2$ Casa 4 \\
3 & 6 & 2 Casa $2+2$ Casa 4 \\
4 & 5 & 1 Casa $2+1$ Casa $6+2$ Casa 10 \\
5 & 5 & 1 Casa $2+1$ Casa $6+2$ Casa 10 \\
6 & 6 & 2 Casa $4+2$ Casa $7+2$ Casa 10 \\
7 & 2 & 1 Casa $6+1$ Casa $8+1$ Casa $10+1$ Casa 12 \\
8 & 2 & 1 Casa $6+2$ Casa $7+3$ Casa 9 \\
9 & 4 & 1 Casa $8+2$ Casa $11+1$ Casa 12 \\
11 & 4 & 2 Casa $9+2$ Casa $11+1$ Casa 12 \\
12 & 3 & 2 Casa $9+2$ Casa $10+2$ Casa 12 \\
& 5 & 2 Casa $9+1$ Casa $10+1$ Casa 11 \\
\hline
\end{tabular}

Nesse dia, debulharam na eira do Norte, um total de doze casas. Como se pode verificar, essas casas apresentaram-se na eira com grupos de trabalho de dimensão variável compreendendo entre dois a sete elementos. Entretanto ao debulhar, cada casa - com excepção da casa 1 - pôde contar com o concurso informal de elementos pertencentes a outros grupos de trabalho. Nos casos mais expressivos - cf. as debulhas das casas 7, 8 e 11 - esse concurso representou entre 40 a $60 \%$ das necessidades em mão-de-obra e envolveu entre três a quatro outros grupos de trabalho. 
dade da freguesia presentes nos Impérios propriamente ditos. Os festejos mais gerais do São João - no decurso dos quais muitas casas acendem fogueiras, ao redor das quais se concentram grupos de vizinhos, conversando e saltando a fogueira - reforçam a adscrição desta data a uma sociablidade alargada. Integrando tradicionalmente o calendário tradicional da freguesia, o Império de São Pedro possuía também, como vimos, um importante papel na reafirmação do sistema social de tipo «dualista» em que Santa Bárbara, em conjunto com a vizinha freguesia de Santo Espírito, se inscreve.

Na Festa do Sagrado Coração de Jesus - festa «patronal» da freguesia é uma orientação similar que é possível reencontrar. Apresentando a estrutura típica das festas patronais, a Festa envolve, do ponto de vista religioso, a realização, da parte da manhã, de uma missa solene, concelebrada pelos párocos de toda a ilha. Contando com uma participação excepcionalmente elevada, esta missa é geralmente aproveitada para a realização de cerimónias religiosas suplementares, como a primeira comunhão, ou a comunhão solene. Ao fim da tarde, tem lugar uma procissão que percorre a totalidade do lugar do Termo da Igreja e à qual se associam o conjunto das casas da freguesia. A par desta vertente religiosa, a Festa do Sagrado Coração de Jesus comporta também a realização, durante todo o dia, de um arraial, integrado por barracas de comes e bebes, jogos e divertimentos, leilões, etc... A organização da festa está a cargo de uma comissão de seis membros, designada pela comissão cessante. Embora assegure um grande número das tarefas relacionadas com a festa, a comissão apoia-se também no trabalho fornecido «idealmente» pela totalidade das casas da freguesia. Estas têm designadamente a seu cargo tudo aquilo que diz respeito à decoração do itinerário da procissão. Para o efeito, a freguesia é repartida em três partidos - cada um deles agrupando um certo número de lugares - que têm a seu cargo a decoração de um troço específico desse itinerário. Esta associação do conjunto da freguesia às tarefas relacionadas com a organização da festa, bem como a participação importante que o conjunto das casas tem tanto na missa como na procissão, devem ser salientadas. Por seu intermédio, a Festa define-se como um momento particularmente importante de afirmação da freguesia. Simultaneamente, ela constitui também uma ocasião importante do relacionamento da freguesia com o exterior, expressa não apenas no afluxo genérico de pessoas de fora ao arraial, mas ainda nas inúmeras visitas informais que, nessa ocasião, os forasteiros fazem às casas de parentes ou conhecidos seus da freguesia.

É no interior desta configuração sociológica do ciclo anual - que, em certos aspectos, não deixa de evocar o quadro esboçado por Mauss a respeito das sociedades rurais europeias no final do «Essai sur les Variations Saisonnières 
des Sociétés Eskimos» (Mauss, 1983b) ${ }^{1}$ — que se torna possível examinar as novas formas de articulação entre Impérios, estrutura social e tempo decorrentes de um conjunto de mudanças que se têm vindo a esboçar na freguesia nos últimos anos.

Entre essas mudanças conta-se uma tendência para uma menor marcação ritual da Quaresma resultante da gradual implementação local das reformas litúrgicas post-conciliares. Em consequência tem-se vindo a registar um certo enfraquecimento das relações de complementariedade tradicionalmente existentes entre o Carnaval, a Quaresma e os Impérios, que, no caso de Santa Bárbara, é ainda facilitado por um outro factor: o alargamento do tempo dos Impérios e o modo como este tende a pôr em causa as relações de contiguidade temporal existentes entre estes três «ciclos» cerimoniais.

Em consequência deste último factor, os Impérios, de uma ligação exclusiva e formal à Primavera, tendem a vincular-se de modo informal ao período constituído pela Primavera e o Verão. É justamente no quadro da associação privilegiada dessa época do ano a formas mais alargadas de sociabilidade que podem começar por ser entendidas as novas modalidades de articulação entre Impérios, estrutura social e tempo decorrentes do alargamento do tempo dos Impérios. Continuando ligados, na sua adscrição tradicional, a ideias de reiteração cíclica das relações sociais, os Impérios actuam agora também como uma das expressões emblemáticas do tipo de sociabilidade predominante na Primavera e no Verão.

Mas é sobretudo no quadro das transformações que a emigração - principal responsável pelo alargamento do tempo dos Impérios - produziu nesse tipo de sociabilidade que é possível interpretar as novas formas de articulação entre Impérios, estrutura social e tempo decorrentes do alargamento do tempo dos Impérios.

Entre elas avulta a gradual afirmação do Verão como um tempo de momentânea reconstituição da unidade de uma comunidade dividida pela emigração. Esta introduziu de facto uma cisão entre a comunidade real formada pelos habitantes efectivos de Santa Bárbara e a comunidade virtual constituída por estes e por todos aqueles que, embora emigrados, mantêm intactas as suas ligações e o seu sentido de pertença à freguesia. E esta «dipolaridade» da fre-

\footnotetext{
${ }^{1}$ Como se sabe a ideia central desse ensaio é a de que «a vida social não se mantém ao mesmo nível nos diferentes momentos do ano: mas passa por fases sucessivas e regulares de intensidade crescente e decrescente, de repouso e de actividade, de dispêndio e de reparação» (Mauss, 1983b: 473). Referindo-se, no final do ensaio, às sociedades rurais europeias, Mauss sublinha designadamente o modo como «no Inverno, o campo está mergulhado numa espécie de torpor, as migrações sazonais rarefazem, nesse momento, a população; em todo o caso, cada pequeno grupo, familiar ou territorial, vive recolhido sobre si próprio; faltam as ocasiões e os meios de reunião: é a época da dispersão. No Verão, pelo contrário, tudo se reanima; os trabalhadores regressam aos campos; vive-se no exterior em contacto constante com os outros E o momento das festas, dos grandes trabalhos e dos grandes excessos» (id., ibid.).
} 
guesia - para empregar a expressão de Beatriz Rocha-Trindade (1976) — que é momentaneamente posta entre parêntesis nos meses de Verão - em particular Julho e Agosto - devido ao afluxo de um número significativo de emigrantes à freguesia. Acompanhando esta tendência, os Impérios tendem a constituir-se numa peça central desse cíclico «refazer» da comunidade. Da mesma forma que, a um nível mais restrito, eles fornecem, como vimos, uma ocasião para a momentânea reconstituição das relações de parentesco e vizinhança de perto do imperador, a este nível mais amplo eles propõem como que uma plataforma ritual de encontro entre a comunidade real e a comunidade virtual em que se desdobra Santa Bárbara.

E aliás a essa luz que se pode explicar o particular empenho que muitos emigrantes - não aparentados aos diferentes imperadores - colocam na sua participação nos Impérios designadamente por intermédio da irmandade. Essa participação estende-se, por uma lado, à maioria dos emigrantes que se encontram de visita à freguesia nos meses de Verão, caso durante estes meses tenha lugar algum Império. Mas estende-se também, como vimos anteriormente, a muitos emigrantes que, mesmo ausentes, fazem questão em se associar aos Impérios. Fazendo-o eles tornam clara a sua vontade de, mesmo à distância, marcarem a sua condição de membros da freguesia.

Seja na sua expressão tradicional, seja através destas novas modalidades os Impérios aparecem-nos em Santa Bárbara como um dos «marcadores» por excelência do tempo, em particular das configurações sociológicas que este desenha.

A importância deste vínculo entre Impérios, tempo e relações sociais deve ser tanto mais sublinhada quanto uma persistente tradição em Antropologia Social tem interpretado as características sociológicas das cerimónias cíclicas de acordo com uma caracterização de contornos funcionalistas da vida social nas comunidades camponesas. Essas comunidades seriam caracterizadas por uma espécie de deficit crónico de coesão e o papel das cerimónias cíclicas em particular e do ritual em geral seria justamente o de injectar coesão e ordem na estrutura social. Esta forma de encarar o ritual é particularmente bem ilustrada nas concepções de Eric Wolf que, num texto que se tornou num «clássico» da reflexão antropológica sobre as sociedades camponesas, encara o cerimonial como uma espécie de contraponto às tendências corrosivas que ameaçam a coesão da estrutura social: "as relações sociais criam ordem, mas, por vezes, no próprio acto de criação de ordenação, elas criam desordem» (1966: 97). O cerimonial «age de modo a confirmar (...) a ordem social comum, a depurá-la da desordem, a restaurar a sua integridade» (id.: 98). Formulações 


\section{AS FESTAS DO ESPÍRITOSANTOS NOS AÇORES}

idênticas podem reencontrar-se em várias monografias ou ensaios especificamente consagrados ao exame das festividades populares europeias. Salientando o papel coesivo das festas na aldeia castelhana de Valdemora, Susan Freeman interpreta-o como um meio de contrabalançar as tendências centrífugas da organização social; "o complexo missa-festa-reunião, que transmite àsfiestas do pueblo o seu carácter especial, é crucial para obter a união dos grupos domésticos separados nas ocasiões em que eles devem funcionar em conjunto. Os laços de sentimentos, interesse mútuo, cooperação e obrigação que unem a família nuclear nas suas actividades quotidianas, não são suficientemente fortes para colmatar a distância entre os grupos domésticos, e é precisamente nos momentos que exigem uma participação colectiva que as sanções religiosas se tornam operativas» (1970: 97). Num texto consagrado à análise das festas na aldeia portuguesa de São João das Lampas a que já enteriormente fizemos alusão, Joyce Riegelhaupt desenvolve pressupostos similares. Depois de sublinhar «a importância que as festas e os lugares sagrados desempenham na definição da comunidade» (1973: 835), a autora insiste em que «tradicionalmente, têm sido as práticas religiosas - as festas - que fornecem a definição tangível da comunidade - as suas fronteiras, os seus vínculos internos assim como as suas relações externas» (id.: 837).

Postulando uma relação de contornos funcionalistas entre o ritual e a ordem social, este tipo de análises tende a silenciar esse vínculo fundamental entre cerimónias cíclicas e as formas de conceptualização do tempo nas sociedades rurais. 
CAPÍTULO 7

OS DOIS IMPERADORES 
Os Impérios podem pois ser vistos como um conjunto de cerimónias e festejos em honra e louvor da divindade, articulados com um projecto de reiteração cíclica das principais instâncias sobre as quais assenta a organização social.

Esta dupla dimensão dos festejos é de alguma forma reflectida nas características de que se reveste a representação da divindade, por intermédio de um símbolo - a Coroa do Espírito Santo - que, além das características religiosas que lhe são genericamente atribuídas, possui também uma dimensão «política». Responsável desde logo pela designação genérica atribuída aos festejos e ao seu promotor, esta articulação do religioso ao «político» transparece em numerosos outros aspectos do ritual. Entre eles, destaca-se o facto de a cerimónia religiosa central de um Império consistir na coroação, verdadeira réplica de uma cerimónia de investidura do poder. A nomenclatura e as insígnias de que se rodeiam os ajudantes evocam também o mesmo horizonte simbólico. Enquanto designações como as de trinchante, mestre sala, pagem da mesa ou copeiro parecem remeter para a terminologia medieval da «corte à mesa» a de briadores — como vimos uma corruptela de vereadores — é por seu turno retirada da nomenclatura do poder municipal. As varas de que os ajudantes grados se rodeiam, pelo seu lado, parecem também inspirar-se na simbologia medieval do poder local, como referiu, entre outros, Frederico Lopes (1980b). Ou seja, é possível falar, nos Impérios, de uma espécie de dobragem sistemática da linguagem religiosa pela linguagem política, baseada em símbolos e desempenhos retirados do imaginário do poder.

O pensamento local explica este revestimento político da linguagem religiosa a partir das «narrativas de fundação» das Festas do Espírito Santo pela Rainha Santa Isabel. Na freguesia existem duas versões dessas «narrativas». Uma delas preocupa-se sobretudo com os motivos que teriam levado a Rainha a criar as Festas. De acordo com esta versão, as Festas teriam sido prometidas pela Rainha caso o rei D. Diniz e seu filho «acabassem a guerra» que 
mantinham entre si. A outra, por seu turno, relaciona a fundação das Festas do Espírito Santo com a prática da caridade: as Festas teriam sido criadas «para dar de comer à pobreza» — o episódio do «milagre das rosas» é frequentemente evocado para ilustrar este ponto - e a Rainha, pretendendo significar a importância dos pobres, $\operatorname{coróav}^{\wedge}$ um deles «com a sua própria Coroa».

Independentemente da legitimação histórica fornecida por estas narrativas de fundação das Festas do Espírito Santo - que é aliás comum ao conjunto dos Açores - a linguagem simultaneamente religiosa e política dos Impérios parece entretanto particularmente adequada para exprimir o modo como as características religiosas dos festejos se conjugam com o seu trabalho sociológico. De facto, por detrás da linguagem simbólica do político é a própria representação da sociedade que está em jogo: é por seu intermédio que as sociedades se deixam ver na sua unidade e autonomia. E conhecida, por outro lado, a relação entre cerimónias cíclicas e a simbologia política, tanto em inúmeras sociedades não-ocidentais como nas próprias sociedades rurais europeias ${ }^{1}$. E justamente no interior deste quadro que pode ser interpretada esta espécie de apropriação, por uma pequena comunidade rural açoriana do séc. XX, da linguagem do «teatro do estado» (Geertz, 1980) medieval.

Não deixa, deste ponto de vista, de ser significativo que, entre as modalidades «menores» dos Impérios, seja precisamente naquelas que possuem uma dimensão sociológica mais restrita - Esmolas, Jantares - que a Coroa se encontre ausente, e que, inversamente, seja nos Impérios secos, que, como vimos, retêm um significado sociológico mais importante, que ela possa ser reencontrada.

É a partir destes pressupostos que se torna possível precisar com maior rigor a função assegurada pelo imperador no quadro dos Impérios.

Detentor momentâneo da Coroa e oficiante das cerimónias que se centram nela, principal distribuidor e redistribuidor dos alimentos que, ao mesmo tempo que homenageiam a divindade, patrocinam o projecto de reiteração

1 De facto, em muitas sociedades não-ocidentais — particularmente naquelas em que o motivo da «soberania sagrada» é determinante - a regeneração cíclica da ordem natural e social é acompanhada de rituais de regeneração do próprio poder (cf., a título de exemplo, entre alguns estudos mais significativos Adler, 1982 e Bloch, 1987). Guardadas as devidas distâncias, é um horizonte similar que os Impérios evocam. De acordo com a sugestão formulada por Frazer a propósito de certas cerimónias cíclicas europeias (Frazer, 1978: 378), o imperador pode ser no fundo encarado como uma espécie de «temporary king», cujos desempenhos aparecem estreitamente ligados a ideias de renovação da ordem natural e social. 
cíclica das relações sociais a que os Impérios se entregam, o imperador vê-se da facto investido, no decurso dos festejos, de uma dupla função que estamos agora em condições de avaliar plenamente.

Do ponto de vista religioso, ele não só fornece à comunidade a ocasião para que'ela expresse a sua devoção em relação ao Espírito Santo, mas opera também como uma espécie de intermediário entre a comunidade e a divindade. Nos peditórios de géneros, era sobre a sua intervenção que repousava a garantia de protecção das colheitas. No quadro da irmandade o imperador actua por seu turno como o depositário humano de ofertas que, sobretudo nos casos que correspondem a promessas ou a motivações religiosas de ordem mais geral, são em última análise feitas ao Espírito Santo. Daí uma certa ambiguidade que rodeia essas dádivas, apresentadas ora como ofertas feitas ao imperador, ora como ofertas feitas ao Espírito Santo.

Do ponto de vista sociológico o imperador constitui-se por seu turno na figura por intermédio da qual a comunidade representa ciclicamente a sua unidade e identidade. É através das suas funções de distribuidor e redistribuidor de alimentos que ela pode postular a sua existência como um corpo social unificado ${ }^{1}$.

E justamente este duplo estatuto do imperador que a coroação sublinha de forma particularmente clara. Imposição solene ao imperador do símbolo da divindade na sua dupla natureza de garante do bem-estar e de fundamento da ordem social, a coroação opera de facto como uma espécie de investidura do imperador na dupla função que ele próprio assegura no decurso dos festejos. Enquanto acto religioso, ela confirma a relação de particular proximidade à divindade inscrita no seu estatuto religioso de intermediário entre a comunidade e o Espírito Santo. Enquanto imposição de um símbolo de poder, ela ratifica a posição de proeminência e centralidade sociológica que é a do imperador enquanto figura onde a freguesia momentaneamente se revê.

Encarado a partir desta perspectiva, o imperador configura-se portanto como uma função realizada em benefício da comunidade e na qual esta se reconhece. Esta função é entretanto detida por indivíduos concretos e variáveis, que a ela acedem e a exercem de acordo com pressupostos de natureza mais «individualista».

Começámos por observar esse facto quando, ao abordarmos de forma mais detalhada as características religiosas dos Impérios, pusemos em evidência a sua dependência de promessas individuais e o modo como para os seus promotores eles revestiam antes de mais a forma de um «contrato» privado entre eles e a divindade. Voltámos a encontrar essa componente dos Impérios a propósito das suas características sociológicas. Embora se acabe por colocar ao

${ }^{1}$ Acerca do papel sociológico da redistribuição como instrumento da centricidade social, cf. Sahlins, 1978: 188-191. 


\begin{tabular}{lccrc}
\hline & $\begin{array}{c}\text { PRIMEIRO } \\
\text { IMPERIO } \\
\text { S. BÁRBARA }\end{array}$ & $\begin{array}{c}\text { SEGUNDO } \\
\text { IMPÉRIO } \\
\text { S. BÁRBARA }\end{array}$ & $\begin{array}{c}\text { PRIMEIRO } \\
\text { IMPÉRIO } \\
\text { NORTE }\end{array}$ & $\begin{array}{c}\text { SEGUNDO } \\
\text { IMPÉRIO } \\
\text { NORTE }\end{array}$ \\
\hline $\begin{array}{l}\text { Despesa total } \\
\begin{array}{l}\text { Despesa do imperador } \\
\% \text { da despesa do impe- } \\
\text { rador sobre a despesa } \\
\text { total }\end{array}\end{array}$ & $\begin{array}{c}1.600 \\
700\end{array}$ & 1.720 & 1.400 & 1.650 \\
& $44 \%$ & $35 \%$ & 400 & 450 \\
\hline
\end{tabular}

QUADRO 21

Despesa do imperador relativamente ao custo total do Império

(Santa Bárbara, 1987)

(em milhares de escudos)

serviço desse projecto eminentemente colectivo que é o da reiteração cíclica das principais linhas de força sobre as quais assenta a estrutura social local, o alimento circula também nos Impérios ao serviço de uma lógica mais restrita, que se prende com a reafirmação das relações sociais próximas do imperador.

Esta imbricação entre aquilo que poderíamos designar como uma vertente «individualista» dos Impérios e uma vertente de carácter sociológico mais amplo deve ser sublinhada. Uma persistente tradição em ciências sociais tem considerado estas duas facetas de forma dissociada, opondo entre si «individualismo metodológico» e «holismo metodológico». A análise conduzida sugere que não há nos Impérios solução de continuidade entre estas duas vertentes, mas que elas coexistem e se articulam entre si.

\section{III}

Esta dupla natureza do cargo de imperador - simultaneamente função estrutural e desempenho individual - reencontra-se ainda em torno da componente de gasto requerida pelos Impérios.

Como vimos, os Impérios representam hoje em dia uma despesa global situada entre 1.500 e os 2.000 contos, suportada em parte importante - entre 30 a $60 \%$ - pelo imperador. Nos Impérios realizados em 1987, essa despesa oscilou - como podemos verificar no quadro junto - entre os 400 e os 700 contos.

A esse valor - correspondente aos gastos directos imediatos com o Império — devem ainda ser adicionadas outras despesas, em particular, no caso dos 
imperadores emigrantes, as derivadas das deslocações do imperador e dos seus familiares mais próximos. Estas despesas podem perfazer, nos casos mais expressivos, cerca de mil contos. Por outro lado, como tivemos oportunidade de verificar, uma parte das ofertas recebidas por cada imperador insere-se em mecanismos de reciprocidade diferida particularmente relevantes no caso das cabeças de gado: uma parte dessas ofertas retribui um dispêndio anteriormente realizado pelo imperador e outra parte pode, em qualquer momento, ter de ser retribuída. Se às despesas atrás indicadas somarmos estas, obtemos um volume total de despesas que, nos casos mais significativos, pode ascender a $1.200 / 1.500$ contos.

A obtenção deste fundo cerimonial assenta em estratégias de poupança individuais relativamente uniformes. No caso dos Impérios promovidos por emigrantes, a marcação da data do Império é feita com três a quatro anos de antecedência e está condicionada à aquisição de uma situação económica relativamente estabilizada. As poupanças, que até aí se encaminhavam prioritariamente para a obtenção de casa própria e de carro, passam a ser canalizadas para o Império. Mensalmente, uma certa quantidade de dinheiro, correspondente à totalidade ou a parte importante do salário de um dos membros do casal, é posta de lado. Entre os locais, por seu turno, a constituição do fundo cerimonial desenrola-se num prazo mais largo e depende, na maioria dos casos, da acumulação, no quadro da exploração agrícola, de um excedente em cabeças de gado e em géneros susceptível de cobrir uma parte significativa das despesas.

Suscitando estratégias de poupança individuais relativamente padronizadas, os gastos suportados pelo imperador são também susceptíveis, pelo volume médio global que atingem, de fornecerem um terreno propício à afirmação e exibição de reivindicações individuais de prestígio, analisáveis à luz dos pressupostos teóricos do «individualismo metodológico».

Esta tem sido uma perspectiva frequentemente utilizada pela Antropologia em contextos similares. O caso mais conhecido é o do potlatch. Estudada exaustivamente por Boas, esta instituição foi por ele definida como um «método de aquisição de estatuto» (1966: 77). Dominadas por ideias de rivalidade e agonismo muito fortes, as transacções do potlatch teriam como objectivo final o reforço do prestígio e do nome do promotor dessa distribuição de riquezas. Retomadas por Mauss (1983a: 194-205) estas ideias foram conduzidas à exaustão por Ruth Benedict, que viu no «potlatch» a melhor expressão do individualismo violento e exacerbado que definiria o «tipo cultural» Kwakiutl (1935: 182-202). Mais recentemente, tem sido de acordo com pressupostos semelhantes que tem sido conduzida a análise dos sistemas cerimoniais de troca da Nova Guiné. Envolvendo quantidades enormes de riqueza e reservando um papel central à figura do «big man», esses sistemas teriam na procura do prestígio e do renome dos seus promotores individuais um dos seus aspectos mais 
importantes (cf. a este respeito a caracterização do «big man» proposta em Sahlins, 1963).

No quadro das sociedades rurais esses pressupostos reencontram-se em torno do estudo dos «sistemas de cargos» associados às celebrações religiosas das populações da América Central, que forneceram - e, embora numa proporção menor, fornecem ainda hoje em dia ${ }^{1}$ - um dos temas centrais da produção antropológica norte-americana acerca das sociedades camponesas meso-americanas. Integrado por um conjunto muito largo, complexo e hierarquizado de cargos associados às principais celebrações religiosas anuais - Páscoa, festas de santos, etc... - esse sistema, além de acarretar um dispêndio considerável de tempo e trabalho, exige também o gasto de somas avultadas de dinheiro, que vão aumentando à medida que se passa da sua base para o topo. Para a maioria dos autores que se debruçaram sobre os «sistema de cargos», estes defmir-se-iam sobretudo como uma forma de transformação da riqueza acumulada individualmente em prestígio no quadro da comunidade. Para alguns deles, esse dispositivo teria um efeito nivelador. A liquidação ritual de excedentes requerida pelo sistema, ao mesmo tempo que transforma em prestígio os progressos económicos de um indivíduo, impede que ele os utilize para sedimentar e consolidar uma posição de efectiva proeminência na estratificação económica na comunidade. Eric Wolf (1955), Manning Nash (1958) e George Foster (1965) encontram-se entre os defensores desta perspectiva, conhecida pela designação genérica de «interpretação niveladora». Outros autores, porém, tentaram uma aproximação diferente. E o caso de Frank Cancian, que no seu estudo clássico «Economics and Prestige in a Maya Community» (1965), procurou pelo contrário demonstrar que a participação no «sistema de cargos» seria não apenas uma forma de aquisição de prestígio, mas ainda e sobretudo uma forma de legitimar posições de dominância económica. Segundo ele, em vez de produzir «uma comunidade economicamente homogénea» (1965: 140), «o serviço no sistema de cargos legitima as diferenças de riqueza efectivamente existentes» (id., ibid.), uma vez que «a estratificação económica existente é socialmente aceite e mesmo encorajada pelo facto de serem oferecidas maiores recompensas sociais aos ricos» (id., ibid.).

Em Portugal, a articulação entre certas formas de dispêndio ritual, designadamente no quadro da festa, e a obtenção de prestígio individual, tem sido também objecto de algumas análises, centradas designadamente em contextos fortemente marcados pela emigração. Nesses contextos, o fortalecimento - aparentemente paradoxal — de certas festas tradicionais ligar-se-ia ao seu aproveitamento pelos emigrantes como forma de ostentação e prestígio. Assim, em Santa Lúcia (Viana do Castelo), a festa - através de donativos, promes-

1 Entre alguns estudos recentes acerca do sistema de cargos centro-americano contam-se os de Waldemar Smith (1977) e Stanley Brandes (1988). Fora do quadro institucional da antropologia norte-americana, cf. o estudo de D. Dehouve (1974). 
sas monetárias e arrematação de cargos de mordomia - «proporciona um contexto no qual os emigrantes podem converter o sucesso económico obtido no exterior em prestígio social» (Brettell, 1983:190). «É na terra natal, onde todos conhecem o seu ponto de partida, que o grau de mobilidade pode ser verdadeiramente avaliado e reconhecido o prestígio social. Os habitantes da terra são os juízes que avaliam o sucesso dos emigrantes no estrangeiro, e as diversas actividades públicas da igreja tornam-se importantes mecanismos através dos quais se afirma ou confirma este sucesso pois proporcionam ao emigrante uma oportunidade de ostentar abertamente a sua riqueza» (id. ibid.: 191). Idêntico ponto de vista pode ainda encontrar-se no estudo que Pierre Sanchiz consagrou às Romarias do Norte de Portugal (Sanchiz, 1983). A tendência para a monetarização de promessas no seu âmbito é por ele vista como uma forma de ostentação - de "afirmação e reivindicação de prestígio» (id., ibid.: 96) - também ela estreitamente dependente da emigração ${ }^{1}$.

E possível reencontrar tendências idênticas nos Impérios, em particular a partir dos anos 60, em estreita ligação com a emigração. De acordo com os testemunhos locais, teria havido então uma pressão muito forte no sentido da utilização ostentatória dos Impérios: «os imperadores andavam como os macacos pendurados nos galhos das árvores, a ver quem chegava mais alto...» A esse propósito é frequentemente referido o caso de um imperador que, «querendo fazer-se grande», foi ao ponto de, em dia de Império, «distribuir gamas [pastilhas elásticas] e rebuçados pelas crianças». Em resultado dessa pressão foram então introduzidas algumas modificações nas prestações alimentares dos Impérios com destaque para a generalização do abate de uma rês por ocasião da Ceia dos Ajudantes, o melhoramento e diversificação culinárias das refeições destinadas aos ajudantes - tanto das Ceias inicial e final, como das refeições que lhes são correntemente asseguradas no âmbito das tarefas preparatórias do Império - e o aumento de dimensão média das postas de carne distribuídas no quadro da irmandade.

Embora a situação, depois desta pressão inicial, tenha evoluído no sentido de uma certa estabilização, continua a ser possível encontrar, em anos

\footnotetext{
${ }^{1}$ Num estudo recente, Brian O'Neill (1990) pôs também em evidência a presença de motivos relacionados com o prestígio no modo como se estrutura a matança do porco numa aldeia transmontana. Nesse seu texto, Brian O'Neill manifestava «alguma perplexidade» perante abordagens preliminares feitas por mim à articulação entre Festas do Espírito Santo e prestígio individual, referindo a esse propósito uma subestimação da «procura de prestígio individual a favor de uma interpretação centrada nos valores de reciprocidade entre grupos» (O'Neill, 1990: 516 e 517). Espero que a formulação actual do problema contribua para desfazer essa perplexidade. Não de trata — do meu ponto de vista — de subestimar a procura do prestígio individual mas de sublinhar que essa procura tem limites que lhe são fixados pelo próprio envolvimento da comunidade nas Festas.
} 
mais recentes, Imperios em cuja promoção motivos como os da obtenção de prestigio são apontados como determinantes. Foi o caso de dois Impérios realizados em 1981 e 1982 por dois emigrantes que mais tarde se fixaram definitivamente na freguesia. Em ambos os casos, esses Impérios, operando como um instrumento de afirmação e exibição dos progressos económicos realizados no decurso da emigração, podem ser encarados como parte de uma estratégia mais geral de retorno "por cima» à freguesia. Não deixa de ser significativo, a esse respeito, que, em ambos os casos, os imperadores tenham tirado partido das deslocações requeridas pela realização dos respectivos Impérios, quer para realizarem dispendiosas aquisições de terras, quer para iniciarem a construção de casas que são consideradas na freguesia como as mais caras alguma vez construídas por emigrantes. Mais recentemente, um outro Império, desta vez promovido por um imperador residente na freguesia, acusa motivos similares. A sua frente encontrava-se um imperador que, no espaço de alguns anos conseguiu, a par de um papel relevante no sistema político local, uma situação económica proeminente - oriundo de uma família de recursos médios, ele tornou-se um dos lavradores mais abastados da freguesia, sendo ainda considerado na freguesia como um homem com pretensões a poder e a prestígio. O seu Império pode ser justamente interpretado como um meio de aferição e de solidificação do seu estatuto na hierarquia económica e social da freguesia.

A utilização dos Impérios como instrumento de reivindicação de prestígio comporta entretanto um certo número de riscos. Como vimos, as despesas envolvidas na realização dos festejos possuem um sentido sociológico preciso: em articulação com os contributos assegurados pela comunidade é sobre elas que assenta em parte decisiva o trabalho de reiteração das relações sociais a que os Impérios se entregam. A afirmação em seu torno de uma lógica deliberadamente ostentatória, de natureza «individualista», é nessa medida susceptível de ameaçar o alcance desse projecto.

É neste quadro que pode ser interpretado o sentido de um conjunto de narrativas de castigos do Espírito Santo que, em Santa Bárbara, rodeiam os Impérios.

A associação das Festas do Espírito Santo a este tipo de narrativas é um traço geral que se reencontra em todo o arquipélago. A seu propósito, houve mesmo autores que defenderam - de uma forma talvez excessiva - que um halo particularmente «vingativo» rodearia a conceptualização popular predominante nos Açores em relação ao Espírito Santo (cf., entre outros, Ribeiro, Silva, 1983 e Lopes, 1980a, particularmente 246-248). No caso de Santa Bárbara, essas narrativas apresentam uma singular uniformidade. O seu ponto de partida é fornecido por uma situação que era relativamente corrente na freguesia há alguns anos atrás: a realização de dois Impérios em dois dias consecutivos - geralmente o Domingo de Pentecostes e a 2. ${ }^{\text {a }}$ Feira de Pentecostes - numa mesma igrega ou ermida. Os imperadores desses Impérios - designados respectivamente como o imperador do primeiro dia e o imperador do 
segundo dia - mantinham entre si uma relação de «vizinhança» cerimonial tradicionalmente regulamentada de forma estrita, que se estendia quer às sequências de conteúdo mais estritamente religioso, quer às várias formas de circulação cerimonial do alimento. Relativamente às primeiras, destaque-se a participação do imperador e imperatriz do segundo dia nos principais cortejos promovidos pelo imperador do primeiro dia e vice-versa ${ }^{1}$. Na esfera alimentar, por seu turno, estes imperadores ofereciam-se mutuamente algumas das principais prestações alimentares previstas na sequência ritual dos festejos, com destaque para as escaldadas e para a irmandade. Era também tradicional a participação mútua nas Ceias de Ajudantes. A Ceia dos Ajudantes final, em particular, era uma refeição conjunta, englobando, para além dos imperadores, a totalidade dos ajudantes de cada um dos Impérios. Quem a assegurava era o imperador do segundo dia, devendo o imperador de primeiro dia, em contrapartida, oferecer ao outro Império uma mesada especial de Sopas do Espírito Santo quando este, no domingo à tarde, chegava à copeira ${ }^{2}$.

Nas narrativas que nos interessam, existe uma diferença central entre esses dois Impérios: enquanto um deles é apresentado como pobre, o outro pelo contrário é apresentado não só como particularmenteforte, mas também como especialmentefanfarrão: fazendo disso público motivo de orgulho, o seu imperador apresenta-se a si próprio como mais forte, vangloriando-se do facto e secundando-o com a depreciação do imperador pobre. Por vezes, ele toma mesmo iniciativas hostilizadoras do imperador pobre. E a partir desta situação da base que se dá a intervenção do Espírito Santo. Em dia de Império, o imperador mais forte vê-se privado de alimentos, sendo por essa razão forçado a interromper a sua distribuição pública - uma situação considerada como particularmente humilhante e que é interpretada como um castigo do Espírito Santo.

Passemos em revista algumas dessas narrativas ${ }^{3}$. Numa delas os intervenientes principais são um Tio Chaves, imperador de primeiro dia e um Zé do Cabeço, imperador de segundo dia. Enquanto que este último «tinha mui pouquinho», o Tio Chaves, pelo contrário, tinha um Império «fortíssimo»: em

\footnotetext{
${ }^{1}$ Nestes cortejos, o imperador e a imperatriz do outro Império ocupam uma posição de destaque. Em dia de Império, em particular, eles seguem no interior do quadro.

${ }^{2}$ Os mecanismos que passámos em revista são os mais importantes. Simultaneamente existem um conjunto de outros dispositivos rituais de pormenor. Actualmente, com o alargamento do tempo dos Impérios, estes dispositivos passaram a abranger o conjunto dos Impérios que se realizam no mesmo período do ano, independentemente da igreja ou ermida em que têm lugar. Em 1987, excepcionalmente, o conjunto dos quatro Impérios, embora separados por um período considerável de tempo - mais de três meses entre o primeiro e o último - mantiveram entre si este tipo de relações.

${ }^{3} \mathrm{Na}$ transcrição das narrativas procurei ser fiel à sua oralidade. Por razões compreensíveis, procedi entretanto a alterações nos nomes dos intervenientes.
} 
vez dos dois carros de bois encarregues do transporte da carne e do pão, o cortejo que levou o seu Império para a copeira integrava quatro carros, tal era a abundância de alimentos. Esse Tio Chaves vangloriava-se muito da força do seu Império comparando-o com a pobreza do outro imperador, dizia ele que «se tinha tanto era para deixar a Zé do Cabeço que não tinha nada». «Foi-se a ver, 110 dia de Império, à tarde, o tio Chaves já não tinha nada para dar, teve que pôr a caixa do pão à porta da copeira» ${ }^{1}$. Foram então chamar o outro imperador, dizendo-lhe que já podia entrar. «Ele deu em chorar: se o tio Chaves, que tinha um Império tão forte, tinha ficado sem nada para dar, que seria dele que era pobrinho... Pois bem, o Zé do Cabeço entrou e fez um Império que era uma flor, não faltava nada. E o outro, que era tão fofo, não só ficou sem Sopas como só tinha leite para dar aos ajudantes do Império do Zé do Cabeço quando este se chegou à copeira». Uma outra narrativa diz respeito a dois Impérios que se realizaram no Norte, na ermida de Nossa Senhora de Lourdes. O imperador do primeiro dia era um António Bairos «que pouco tinha de seu para o Império; para a copeira levou só três quartos de uma vaquinha e uma ovelha». O imperador de segundo dia era um Manuel Andrade Melo. Passava o tempo a vangloriar-se daforça do seu Império: «eu cá tenho um Imperiozão, ao passo que António esse não tem nada». No Domingo, chegou mesmo a proibir os seus ajudantes de comerem Sopas do outro Império, «porque ele tinha que bastasse». No dia seguinte, para as Sopas da manhã, «a carne dele estava crua. E chegou-se ao meio dia e não tinha mais que dar. Era mui fofo e foi o que se viu...» Enquanto isso, o outro Império não teve problemas: "três quartos de uma vaca deram para tudo...» Uma outra narrativa recorrentemente evocada na freguesia diz respeito a dois Impérios, um deles promovido no primeiro dia por uma Emília Soares, «pobrinha», e outro promovido no segundo dia, por uma tia Maria Resendes, «rica». Apesar de «pobrinho» o Império do primeiro dia «tinha ainda muito que dar quando se chegou a hora do outro entrar». Por isso, foi-lhes pedido que retardassem o cortejo, por forma a permitir uma ou duas mesadas suplementares. A tia Maria Resendes, «que era muito fofa, disse que não, que era chegada a sua hora, e que eles que botassem a carne na estrumeira, que ela tinha um poder de carne e pão para dar e que não podia esperar». A outra imperatriz acabou por ceder, mas esta «tia Maria Resendes, que se tinha feito tão fofa, no dia seguinte, à tarde, já queria ir matar mais uma gueixa, que não tinham carne para dar; chegou-se a meio da tarde, tiveram que meter a caixa na rua...»

Por intermédio deste conjunto de narrativas, é a uma condenação das utilização mais deliberadamente «ostentatórias» dos Impérios que é possível

1 A colocação da caixa do pão à entrada da copeira é o sinal convencionalmente fixado para significar que um Império esgotou os alimentos que tinha para distribuir. A caixa do pão é a utilizada no transporte do pão de trigo para as Sopas no quadro do cortejo que leva o Império para a copeira. 
assistir. As verbalizações das pessoas insistem particularmente nesse ponto. $\mathrm{E}$ a «fofice» que «deita a perder» os imperadores, «querem-se grandes e o mal já lhes está batendo à porta», «aquilo faz-se com fé, não é para sermos grandes», «o Espírito Santo não gosta de fanforrias», etc...

Esta condenação da utilização ostentatória dos Impérios por parte dos seus promotores individuais é tanto mais interessante quanto contrasta de forma flagrante com a atitude prevalecente em relação aos Impérios como instrumento de afirmação da identidade colectiva. Aí, pelo contrário - como tivemos oportunidade de ver - as reclamações de força são não só admitidas como constituem mesmo um dos dispositivos centrais do discurso que a comunidade investe nos Impérios. Entre essas duas atitudes contrastantes existe uma relação necessária: para que a identidade da freguesia se possa afirmar por intermédio dos Impérios e, em particular, das reclamações que se fundam sobre a sua força, é necessário que esta seja vista não como o resultado de uma «performance» estritamente individual, mas como um produto essencialmente colectivo. A «função» do imperador deve sobrepor-se ao seu «desempenho individual».

O insucesso dos imperadores fofos é, por outro lado, explicitamente confrontado nas narrativas que passámos em revista com o sucesso - apesar das suas dificuldades e contra as expectativas dominantes - dos imperadores pobres. E tal como o primeiro é pensado como uma sanção sobrenatural, o segundo é também frequentemente verbalizado em termos de «milagre». Esta vertente é complementar da anterior. Em ambos os casos, o que estas narrativas procuram vincar é justamente a predominância da «função» sobre o «desempenho individual». Por isso, ao mesmo tempo que desqualificam as utilizações mais abertamente «ostentatórias» dos Impérios enquanto elemento susceptível de desvirtuar a sua lógica, elas empenham-se em viabilizar o desempenho integral dessa «função» nos casos em que ele, inversamente, se apresenta como problemático.

Esta última parte da demonstração não é aliás meramente «teórica», como o prova um Império realizado recentemente na freguesia. Prometido «numa hora de aflição» - devido a motivos de saúde - à sua frente encontrava-se uma casa da fracos recursos económicos. Sem terras suas, trabalhando à jorna, o imperador era generalizadamente descrito como «não tendo nada de seu»: «se ele fosse a fazer o Império com o que tinha, nem para um Jantar dava...». Entretanto, o Império apresentou um nível de abundância similar ao da generalidade dos Impérios realizados na freguesia. A comunidade empenhou-se de forma particularmente intensa na irmandade e, por seu intermédio, cobriu um 
conjunto de despesas que, noutros casos, são suportadas pelo imperador. De facto, se as despesas globais desse Império se aproximaram dos valores médios da freguesia - 1.200 contos - a proporção entre o contributo próprio do imperador e o contributo da comunidade - $15 \%$ contra $85 \%$ - apresentou entretanto valores diferentes daqueles que são usuais na freguesia - situados, como vimos, entre os $30 / 60 \%$ contra $70 / 40 \%$. O contributo da comunidade foi particularmente relevante em relação ao gado. Das oito reses abatidas para o Império apenas uma e meia foram suportadas pelo imperador, sendo de destacar que, entre as reses que lhe foram oferecidas, pelo menos duas foram-no sem qualquer expectativa de retorno posterior: os indivíduos que as ofereceram tinham-nas prometido ao «imperador mais pobre da freguesia». Quanto à irmandade em pães de mesa e roscas atingiu um total de cento e cinco ofertas, um número bastante significativo no contexto geral da freguesia.

O caso que passámos em revista não é único. Já depois de concluído o trabalho de terreno em Santa Bárbara, voltaram a realizar-se dois Impérios promovidos por casas de fracos recursos económicos. Apesar desse facto, um deles - que teve lugar em 1989 - foi, em termos de gado abatido, o mais forte que alguma vez se realizou na freguesia: no seu decurso foram abatidas doze reses. Em 1990, por seu turno, realizou-se também um Império de herdeiros - a que já fizemos anteriormente referência - , que abateu oito reses e à frente do qual se encontravam duas casas de fracos recursos económicos. Tal como no caso anterior, também nestes dois casos foi decisivo o contributo dado pela comunidade. Assim, das doze e oito reses respectivamente abatidas em cada um destes Impérios, apenas duas, foram, em cada um deles, directamente suportadas pelos seus promotores individuais.

Isto é: de acordo com as narrativas que constroi, a própria comunidade empenha-se em assegurar o sucesso dos Impérios pobres, viabilizando de forma prática o desempenho integral da «função» de imperador. 
PARTE II

DIVERSIDADE E UNIDADE DAS FESTAS

DO ESPÍRITO SANTO 
CAPítulo 8

OUTRAS ILHAS, OUTRAS FESTAS 
A unidade e a diversidade que caracterizam os Açores têm sido persistentemente sublinhadas.

Em dois ensaios clássicos de Vitorino Nemésio (Nemésio, 1986a; 1986b) essa dialéctica foi surpreendida por referência à psicologia colectiva dos insulares. Baseada em critérios eminentemente impressionistas, essa forma de encarar a unidade e a diversidade dos Açores reencontra-se em tentativas posteriores de equacionar o problema, oriundas sobretudo da área da literatura (cf., por exemplo, Almeida, Onésimo T., 1980 e 1989). Simultaneamente, aproximações mais parcelares a essa dialéctica têm sido conduzidas a partir do ponto de vista da geografia humana (cf. Ribeiro, Orlando, 1955) e da etnologia (cf. Furtado, 1884 e Ribeiro, Luís 1983 e, mais recentemente, Martins, Rui Sousa, 1989)

Com argumentos variáveis o que se procura pôr em evidência é, por um lado, a singularidade e unidade dos principais motivos que presidem à cultura açoriana, e, por outro, a diversidade de formas que esses motivos adquirem no interior do arquipélago.

E para essa dialéctica entre unidade e diversidade que nos remetem as Festas do Espírito Santo. Presentes em todo o arquipélago, configurando-se como um dos traços centrais da unidade e da especificidade dos Açores enquanto «área cultural», as Festas do Espírito Santo apresentam simultaneamente uma grande diversidade, entre os diferentes grupos de ilhas, de ilha para ilha, e, mesmo, por vezes, dentro de cada ilha, de freguesia para freguesia.

Essa diversidade cristaliza-se na existência, ao longo do arquipélago, de cinco grandes variantes das Festas do Espírito Santo. Uma delas é constituída pelos Impérios de Santa Maria. Simultaneamente, é possível detectar a existência no arquipélago de quatro outros grandes modelos de organização dos festejos. O mais difundido e conhecido encontra-se nas ilhas do grupo cen- 


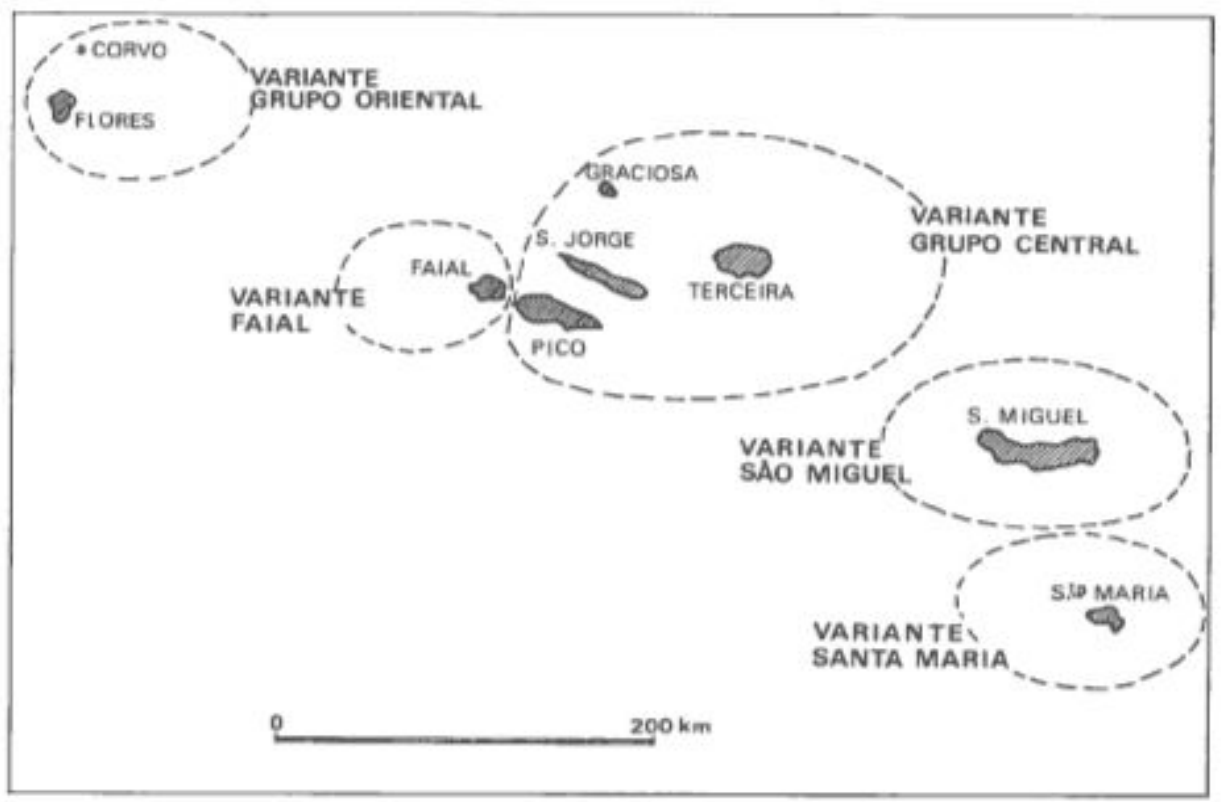

MAPA 8

Principais variantes das festas do Espírito Santo nos Açores

trai. Atingindo a sua forma mais elaborada na Terceira, em São Jorge e no Pico, este modelo reencontra-se ainda na Graciosa. Além de excepções pontuais - designadamente na Terceira - a única ilha que, no grupo central, se afasta deste tipo estrutural, é a do Faial, onde prevalece uma variante distinta de organização dos festejos. Um outro modelo do ritual é o que podemos encontrar em São Miguel. As Flores e o Corvo, por fim, constituem a área de difusão da última variante (cf. mapa 8$)^{1}$.

${ }^{1}$ É difícil encontrar estudos de carácter geral sobre as Festas do Espírito Santo no conjunto dos Açores. De uma forma geral, de facto, a tradição etnográfica existente no arquipélago tem privilegiado contextos mais restritos, como a ilha ou a freguesia. Veja-se de qualquer forma Costa, Carreiro da (1957) e Breda Simões (1987). O primeiro constitui uma tentativa de apresentação, ilha por ilha, das Festas do Espírito Santo no conjunto do arquipélago; o carácter restrito da bibliografia em que se apoia, torna-o entretanto bastante incompleto. O segundo é um «roteiro lexical» das Festas do Espírito Santo nos Açores. Em Oliveira Martins (1985), além de abundante e diversificada documentação fotográfica, pode-se encontrar também a reprodução de alguns estudos etnográficos parcelares sobre as Festas do Espírito Santo em cada uma das ilhas. Quanto à tentativa de síntese ensaiada no presente capítulo, ela baseia-se simultaneamente em recolhas próprias conduzidas nas diferentes ilhas e na consulta da bibliografia disponível. 
As diferenças entre estas cinco variantes dizem fundamentalmente respeito aos grandes motivos caracterizadores das Festas do Espírito Santo. As variações mais significativas são as que se relacionam com a estruturação genérica do ritual, com o conteúdo e características principais da sua vertente alimentar e, por fim, com o tipo de cerimónias religiosas que eles compreendem.

A par destes grandes motivos, existem outros de natureza mais específica, cuja variação ao longo do arquipélago obedece a padrões aparentados, embora não directamente sobreponíveis. É o que passa quanto à composição das folias 1 . De facto, a par do modelo de folia característico de Santa Maria são ainda detectáveis no arquipélago os seguintes tipos principais de folias: a) a folia do grupo central - que se compõe de um tambor e de um pandeiro, além do «porta-bandeira» - característica das ilhas da Terceira, São Jorge, Pico, Graciosa e Faial e ainda, da parte oriental da ilha de São Miguel²; este tipo de folia apresenta algumas variantes menores - assim, em certos casos, o pandeiro desaparece, podendo ser eventualmente substituído por um tambor suplementar ${ }^{3}$; b) a folia de São Miguel — de origem recente, é hoje a mais difundida na ilha; integra um pandeiro, viola, rebeca e ferrinhos; c) a folia das Flores e Corvo - composta por um tambor, testos ${ }^{4}$ e dois cantadores, um dos quais o "porta-bandeira»; tradicionalmente esta folia integrava também um pandeiro, entretanto caído em desuso.

A arquitectura religiosa de apoio às Festas do Espírito Santo apresenta também alguns pontos comuns com o padrão de distribuição regional das cinco principais variantes das Festas do Espírito Santo. Em Santa Maria, como vimos, existiam dois edifícios vinculados ao culto do Espírito Santo - o teatro e a copeira. Desses edifícios, um deles - o teatro - possui

Embora os dados provenientes de ambas as fontes possam ser considerados suficientemente representatativos, certamente que estudos posteriores permitirão afinar, ou, mesmo, nalguns casos, rectificar, a tipologia proposta. Para não tornar o capítulo excessivamente denso, circunscrevi-me, em relação a cada uma das variantes, às suas principais linhas caracterizadoras, com abandono de aspectos de carácter mais detalhado.

${ }^{1}$ Uma apresentação mais detalhada das folias dos Açores - com particular destaque para o instrumental utilizado — pode encontrar-se em Veiga de Oliveira, 1986: 26-29. A tipologia que em seguida propomos difere entretanto nalguns pontos da defendida nesse texto. Para alguns aspectos gerais relacionados com as folias nos Açores, cf. também Ribeiro, Luís Silva, 1982.

${ }^{2}$ A respeito da difusão deste tipo defolia em São Miguel, cf. Veiga de Oliveira, 1986: 27.

${ }^{3}$ Assim, em São Jorge, nas freguesias dos Rosais — cf. Veiga de Oliveira, 1986, 27 de Santo Antão e do Topo, e, no Pico, nas freguesias da Piedade e da Ribeirinha, a folia compunha-se exclusivamente de um cantador e de um tambor; no Pico, na freguesia da Candelária - cf. Veiga de Oliveira, id. ibid. - compunha-se de dois tambores.

${ }^{4}$ Os testos usados nas Flores, embora genericamente similares aos de Santa Maria, diferenciam-se destes pelo facto de um dos pratos ser de dimensão mais pequena; o tipo de toque é também diferente do usado em Santa Maria. 
equivalentes em todas as ilhas dos Açores. Entretanto, tanto a sua designação como as suas principais características arquitectónicas e funcionais apresentam variações significativas. Assim no grupo central - com excepção da ilha do Pico, onde a expressão mais utilizada é a de Capela - predomina a designação de Império, sendo este, na sua forma mais simples, um pequeno edifício tipo ermida, de planta rectangular ou quadrada, fechado, com frontaria geralmente decorada e encimada por uma Coroa do Espírito Santo, que, além das funções que desempenha no âmbito dos festejos, alberga ainda durante o ano as Coroas e outras insígnias do Espírito Santo. Nalguns casos, o Império possui ainda uma pequena dispensa anexa, de construção geralmente mais recente. Em certos Impérios do Faial, esses anexos compreendem também uma copeira e uma cozinha, geralmente também de construção recente. Em certas freguesias de São Jorge, além do Império, existe ainda uma Casa do Espírito Santo, de funções similares à copeira de Santa Maria. Embora predominante no conjunto das ilhas do grupo central, é na ilha Terceira que este tipo de Impérios atinge a sua mais elaborada expressão. A sua decoração exterior é particularmente cuidada e a fachada, geralmente encimada por um frontão triangular, apresenta uma mistura de branco e cores vistosas que conferem ao edifício uma personalidade muito marcada ${ }^{1}$ Em São Miguel, a designação mais antiga, ainda hoje frequentemente utilizada, é, como em Santa Maria, a de teatro; em muitos casos, encontra-se porém a designação de Império. Quanto às características arquitectónicas do edifício, elas oscilam entre uma construção de tipo «alpendre» - similar à usada em Santa Maria - e o tipo de contração predominante no grupo central ${ }^{2}$. Nas Flores e no Corvo, finalmente, predomina a designação de Casa do Espírito Santo. Esta, no caso mais usual, é um edifício térreo relativamente amplo, de planta rectangular, no interior do qual existe um altar onde são guardadas as insígnias do Espírito Santo.

\section{II}

No grupo central, as Festas do Espírito Santo encontram-se particularmente bem estudadas na ilha Terceira, graças tanto a um conjunto de contri-

\footnotetext{
${ }^{1}$ É talvez por esta razão que José Manuel Fernandes (1989: 67) considera os Impérios da Terceira uma categoria própria, distinta dos restantes Impérios do grupo central, por ele designados através da expressão Impérios-capela. Esta distinção tem entretanto um cunho sobretudo arquitectónico: de um ponto de vista funcional não parece de facto haver diferenças de fundo entre os diferentes Impérios das ilhas do grupo central.

${ }^{2}$ Acerca dos teatros em São Miguel, cf. Leite de Ataíde, 1973: 250-256.
} 


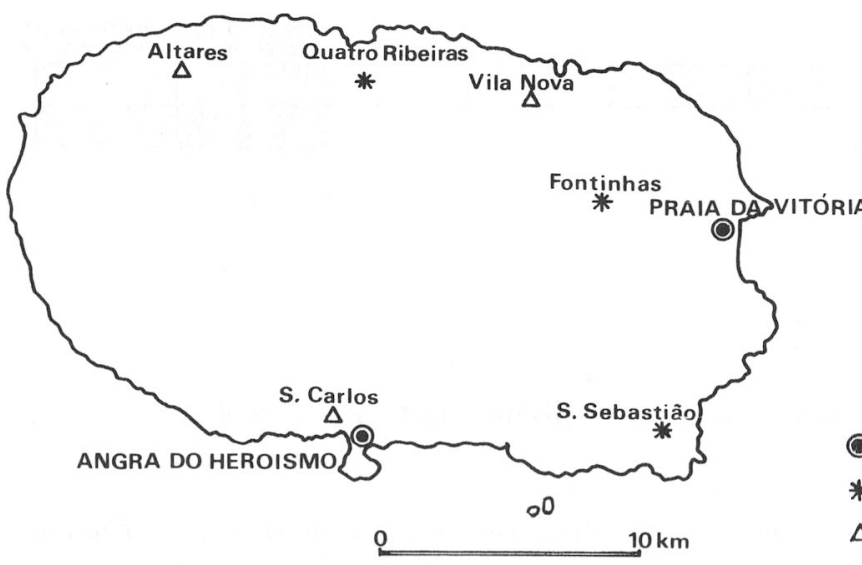

- Sede de concelho

* - Recolha própria

$\Delta$ - Fontes bibliográficas

MAPA 9

Festas do Espírito Santo na Terceira: Fontes da recolha

butos de características etnográficas - entre os quais avultam os de Frederico Lopes (1980a) e de Inocêncio Enes (1948) - como a alguns estudos de natureza etnológica - com particular realce para os de Mari Lynn Salvador (1981; $1985)^{1}$. Tomando como base esses estudos, a apresentação a que procederemos de seguida incorpora ainda os resultados de algumas recolhas próprias conduzidas nas freguesias das Fontinhas, Quatro Ribeiras e São Sebastião (cf. mapa 9).

Desenrolando-se ao longo do período de oito semanas que medeia entre o domingo de Páscoa e o domingo da Trindade, as Festas do Espírito Santo compreendem na Terceira dois tipos distintos de cerimónias, conhecidos genericamente sob a designação de Funções e Bodos. As Funções têm lugar ao longo de cada uma das oito semanas do período tradicionalmente consagrado

${ }^{1} \mathrm{O}$ estudo de Frederico Lopes possui carácter geral. Quanto ao de Inocêncio Enes diz respeito à freguesia dos Altares. Os textos de Mari Lyn Salvador, por fim, embora possuam carácter geral, apoiam-se sobretudo em elementos recolhidos nas seguintes freguesias: Santa Luzia, Quatro Cantos, Corpo Santo, São João de Deus e São Carlos na área urbana de Angra do Heró́smo, e Ribeirinha, São Sebastião, Altares, Lajes e Vila Nova, na área rural (Salvador, 1985: 244). Além destes textos, integram ainda a bibliografia disponível acerca das Festas do Espírito Santo na Terceira: Costa, Antonieta (1987) - centrado no Império de São Carlos Dias, Maria Alice (1982: 132-153) e Lima, Gervásio (1932: 33-46 e 73-78) — ambos estudos de características gerais - e ainda Ormonde, Maria Helena (1985/6: 79-95) - acerca da freguesia de Vila Nova. No mapa 2 e seguintes, além da indicação das freguesias em que conduzi recolhas próprias, são também identificadas as freguesias sobre as quais é possível dispor de estudos específicos. 
AS FESTAS DO ESPÍRITO SANTO NOS AÇORES

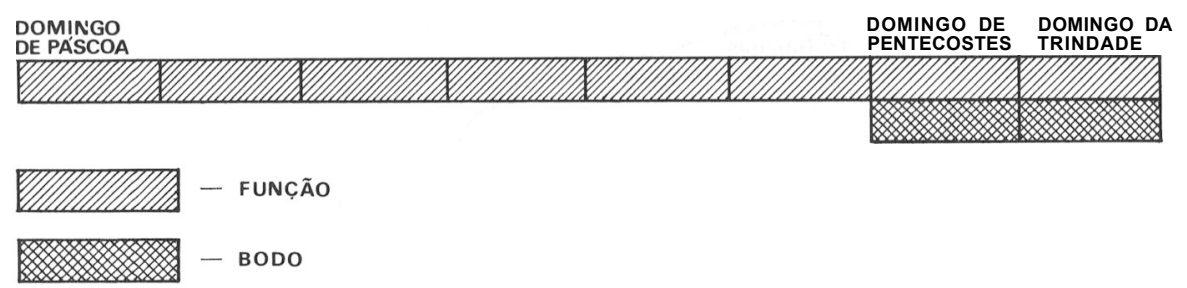

FIGURA 7

Estrutura das Festas do Espírito Santo na Terceira

à realização dos festejos. Os Bodos realizam-se, em paralelo com as Funções dessas semanas, nos domingos de Pentecostes e da Trindade. Ambas as celebrações, além de obedecerem a modalidades de organização e a um conteúdo ritual distintos, caracterizam-se ainda por uma certa autonomia mútua. A sua amplitude é também diversa (cf. figura 7).

As Funções possuem um âmbito mais restrito. Na sua base encontram-se promessas individuais. A frente de cada uma delas está um imperador que é o responsável pelos festejos no decurso da semana que - de acordo com um sorteio realizado no ano anterior e conhecido sob a designação de tirar os pelouros - lhe coube em sorte. Os festejos centram-se em casa do imperador, onde são instaladas, num altar erguido especificamente para o efeito, as insignias do Espírito Santo: uma ou mais Coroas, acompanhadas das respectivas bandeiras, um certo número de varas e/ou tochas e, eventualmente, um espadim.

As Funções comportam, em primeiro lugar, um conjunto de cerimónias de características religiosas. Durante a semana tem lugar, junto ao altar, a recitação diária do terço. Este terço obedecia a um padrão tradicionalmente fixado e era em geral cantado ${ }^{1}$. No domingo, no termo da missa, realiza-se por seu turno a coroação, que constitui a cerimónia religiosa fulcral da Função. Tradicionalmente a coroação incidia ora sobre o imperador, ora sobre uma criança por ele escolhida. Hoje em dia, porém, o imperador só coroa caso tenha feito uma promessa específica nesse sentido. De uma forma geral são uma ou mais crianças ou adolescentes, ora do sexo masculino, ora do sexo feminino, escolhidos geralmente entre os filhos ou filhas do imperador, quém são coroados. Simultaneamente ao terço e à coroação, as Funções articulam-se ainda com um conjunto de cortejos, entre os quais avultam os que rodeiam a coroação e aquele que, no termo de cada um dos domingos, procede à mudança das Coroas e outras insígnias do Espírito Santo da casa do impe-

\footnotetext{
${ }^{1}$ Para uma apresentação mais detalhada do terço na Terceira, cf. Lopes, 1980a: 267-278
} 
rador cessante para a casa do imperador da semana seguinte ${ }^{1}$. Embora com diferenças de pormenor de freguesia para freguesia, estes cortejos apresentam um certo número de constantes. O transporte das Coroas - que fecham o cortejo - está a cargo de um ou mais pagens da coroa, enquanto o das bandeiras - que abrem o cortejo - compete a um ou mais alferes da bandeira; as varas e/ou tochas enquadram as Coroas e as bandeiras, sendo o seu transporte confiado, em certas freguesias, aos imperadores das Funções das

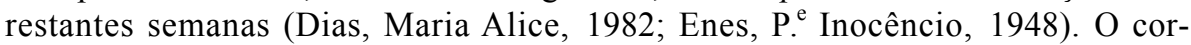
tejo que se segue à coroação propriamente dita, por fím, possui como traço peculiar o facto de as Coroas seguirem à cabeça das crianças ou adolescentes coroados, sendo cada um deles rodeado por um quadro formado com auxílio das varas. Tanto estes cortejos como outras sequências rituais previstas na estrutura das Funções, eram tradicionalmente dirigidos e acompanhados pela folia. Entretanto, no decurso dos últimos 30/40 anos, a maioria das folias da ilha entrou em declínio e, actualmente, o acompanhamento musical das Funções é generalizadamente feito por filarmónicas.

Em simultâneo com estas cerimónias de características religiosas, as Funções articulam-se com um conjunto de prestações de natureza alimentar. Estas exigem o abate de uma a três reses - utilizadas na confecção de um certo número de pratos, entre os quais se destacam as Sopas do Espírito Santo e a alcatra - e a preparação de diversas qualidades de pão de trigo, massa sovada e pão de leite ${ }^{2}$. A confecção destes diferentes alimentos está a cargo de um grupo de mulheres, dirigidas por uma mestra. $\mathrm{O}$ abate e a preparação prévia das reses - que aparece rodeada de uma certa cerimonialização, expressa na realização de um desfile prévio de gado, conhecido pela designação de bezerrada - compete por seu turno a um grupo de ajudantes masculinos, orientados por um marchante. Embora o imperador receba algumas ofertas, em géneros ou dinheiro, de parentes e vizinhos, o essencial da despesa é suportada por ele. Em relação ao gado, entretanto, muitos imperadores recorrem com alguma frequência aos préstimos de um criador, um pastor ou criador de gado que, a seu pedido, toma gratuitamente conta, durante um certo período de tempo, das reses adquiridas para a Função. Em sinal de agradecimento, o imperador reserva-lhe depois, no quadro da Função, um tratamento de honra.

Do conjunto de prestações alimentares que integram a sequência ritual da Função a mais importante é constituída por uma grande refeição colectiva, servida em casa do imperador a seguir à coroação. Esta refeição - conhecida pela designação de jantar — possui como característica distintiva cen-

\footnotetext{
${ }^{1}$ As mudanças de Coroa realizavam-se geralmente ao fim da tarde ou ao princípio da noite; parece ser nessa circunstância que se filia o uso, entre as insígnias do Espírito Santo, de tochas que, acendidas para o efeito, iluminavam o percurso do cortejo.

2 Para mais detalhes acerca dos aspectos culinários destes diferentes alimentos cf. Lopes, 1980a: 230-231
} 
trai o facto de ser reservada a convidados do imperador, em números que atingem frequentemente as duas ou três centenas. Em certos casos, é usual o imperador alargar informalmente esses convites às pessoas - designadamente forasteiros - que passam pelas imediações do local onde se realiza ojantar. No decurso dessa refeição são servidas Sopas do Espirito Santo, carnes cozidas, alcatra e ainda massa sovada e pão de leite. Simultaneamente, a estrutura ritual das Funções prevê ainda um certo número de outras prestações alimentares, entre as quais avultam as distribuições de esmolas. Resultantes geralmente de promessas específicas feitas nesse sentido, estas esmolas desdobram-se em duas modalidades principais: a primeira corresponde às chamadas esmolas de mesa e consiste na distribuição, a um certo número de casas mais pobres do lugar ou da freguesia, de um sopa com carne cozida e de um pão; a segunda consiste na distribuição, a crianças e a pobres, de um pão de trigo conhecido pela designação de pão dos inocentes. Na generalidade dos casos, os festejos integram também prestações alimentares de carácter mais restrito destinadas quer aos ajudantes quer às casas que fizeram ofertas em géneros ou dinheiro como contributo para as despesas da Função.

O esquema genérico que acabámos de apresentar é comum à grande maioria das freguesias da Terceira. Nos últimos anos, entretanto, a par de uma generalização das Funções fora do tempo - promovidas em geral por emigrantes - tem-se verificado um certo declínio das Funções realizadas ao longo do período tradicionalmente previsto para o efeito. Esse processo tem afectado em particular as seis semanas anteriores ao Pentecostes e à Trindade. Em vez das Funções realizam-se então sucessivas estadas das Coroas em casas que se oferecem para o efeito e, embora a coroação e a recitação diária do terço se continuem a realizar, todo o restante cerimonial - designadamente o conjunto de formas de circulação do alimento que acabámos de passar em revista - é suprimido.

Em confronto com o carácter algo restrito das Funções, os Bodos constituem celebrações de características mais amplas. O seu ponto alto é constituído por uma distribuição de alimentos - massa sovada ou pão de trigo e vinho - que se realiza nos domingos de Pentecostes e da Trindade e que possui como traço distintivo o seu carácter generalizado. Quem quer que o solicite é convidado a servir-se do alimento distribuído. Nalguns casos, além desta distribuição ampla de alimentos, realiza-se ainda, na 2. ${ }^{a}$ feira seguinte, uma distribuição porta-a-porta de pão e vinho restrita às casas da freguesia ou do lugar. Simultaneamente a estas distribuições de alimentos, têm lugar um conjunto de outras festividades de carácter variado: arraial, bailes, exibições de filarmónicas, arrematações de promessas oferecidas por devotos ao Espírito Santo, etc...

Este conjunto de festividades centra-se, em cada freguesia ou lugar, no Império respectivo, onde a Coroa fica depositada durante o dia. A sua promoção - particularmente o financiamento e a preparação dos alimentos 
distribuídos no decurso do Bodo - assenta em formas de mordomia colectiva, articuladas com modalidades de intervenção do conjunto da comunidade, variáveis de freguesia para freguesia. Demos alguns exemplos. Nas Fontinhas, a realização do Bodo assenta num grupo de cerca de vinte mordomos designados por um período de oito a dez anos. Ao longo desse período, a direcção dos festejos e respectivos preparativos compete, à vez, a dois desses mordomos, um responsável pelo Bodo do Espírito Santo e outro responsável pelo Bodo da Trindade. Os restantes mordomos, por seu turno, devem entregar anualmente para cada um do Bodos um total de vinte e cinco pães e $3.000 \$ 00$. $\mathrm{O}$ resto dos alimentos é financiado com recurso a um peditório realizado pela freguesia. Na Vila Nova, por seu turno, os festejos assentam num grupo de irmãos - ou irmandade - de entre os quais são escolhidos, de sete em sete anos, um conjunto de oito mordomos, quatro por cada um dos Bodos. Além de terem a seu cargo a realização de um peditório pela freguesia, estes mordomos devem ainda cozer em sua casa duzentos e cinquenta pães de trigo, dois pães de massa sovada e dez rosquilhas. Quanto aos irmãos devem contribuir para as despesas do Bodo com dez pães e 2.400\$00 (Ormonde, 1985/6: 84-87). Nas Quatro Ribeiras, por fim, os Bodos compreendem, além de uma distribuição generalizada de pão e vinho, uma distribuição de carne crua, restrita às casas da freguesia. Esta última tem lugar nos sábados de Pentecostes e da Trindade e a sua organização compete a três procuradores. Quanto à distribuição de pão e vinho, está a cargo de dois mordomos e assenta em ofertas em pão e em dinheiro - utilizado na compra do vinho - realizadas por casas da freguesia.

O modelo de Festas do Espírito Santo que acabámos de descrever reencontra-se, nas suas linhas gerais, na grande maioria das restantes ilhas do grupo central ${ }^{1}$.

As expressões que designam os dois tipos de festejos em que elas se desdobram apresentam entretanto algumas variações significativas. Assim, em

${ }^{1}$ Os elementos referente a esta seç̧ão baseiam-se em recolhas conduzidas nas freguesias de Topo, Santo Antão, Manadas e no lugar da Beira, na freguesia das Velas, em São Jorge (cf. mapa 10); nas freguesias da Piedade e da Ribeirinha, no Pico (cf. mapa 11); e nas freguesias da Praia, da Luz e do Guadalupe, na Graciosa (cf. mapa 12). Em São Jorge existe ainda uma boa bibliografia acerca das Festas do Espírito Santo, em que se destacam os estudos de Cunha, P. ${ }^{\text {e }}$ Manuel da (1981) - que embora contenha materiais respeitantes a outras freguesias, se baseia sobretudo na freguesia da Ribeira Seca - e Canto e Castro (1946) - referente às Festas do Espírito Santo em Santo Amaro; embora com características mais gerais refiram-se também Mendonça (1961/2) e Avellar (1902). Para a Graciosa não consegui encontrar qualquer estudo específico e, em relação ao Pico, os únicos textos disponíveis são Coelho. M. A. (1961: 314-320 e 344-348) - material referente também à freguesia da Piedade - e a secção do ensaio genérico de Carreiro da Costa referente ao Pico (1957: 31-35). 
AS FESTAS DO ESPÍRITO SANTO NOS AÇORES

\begin{tabular}{llll}
\hline TERCEIRA & SÃO JORGE & PICO & GRACIOSA \\
\hline Função & Jantar & Coroação & Coroação \\
Bodo & Bodo/Festa & Império & Bodo \\
\hline
\end{tabular}

\section{QUADRO 22 \\ Designações dos festejos no grupo central}

São Jorge, as Funções terceirenses são conhecidas pela designação usual de Jantares; e, a par da designação de Bodo - referente ao segundo tipo de festejos - surge também a expressão genérica de Festa. No Pico, as expressões por que são conhecidos os dois tipos de festejos são respectivamente as de Coroação e Império. Na Graciosa, por fim, as designações mais utilizadas são as de Coroação e Bodo (cf. quadro 22).

O nome dado ao promotor individual do primeiro tipo de festejos é também variável. Assim, a par da designação de imperador - prevalecente na Graciosa - encontra-se também a expressão de mordomo - mais usual em São Jorge e no Pico. De uma forma geral a sequência deste primeiro tipo de festejos é, nas suas linhas gerais, idêntico ao que encontrámos na Terceira, embora existam naturalmente variações quer quanto a aspectos da organização da sua vertente religiosa - em particular no tocante à composição e organização dos cortejos que rodeiam a coroação - quer no referente à sua vertente alimentar - alimentos utilizados, modalidades da sua distribuição, etc... Entretanto, em certos casos, registam-se particularidades locais importantes. Assim, em muitas freguesias do Pico e de São Jorge, a escolha do mordomo ou imperador faz-se no quadro de irmandades especificamente ligadas ao culto do Espírito Santo e completamente autónomas da Igreja. Essas irmandades, que podem em certos casos funcionar no âmbito de cada um dos domingos que medeiam entre a Páscoa e o Pentecostes, surgem, na maioria dos casos, preferencialmente vinculadas aos festejos das semanas do Pentecostes e da Trindade e desempenham um papel particularmente importante no seu decurso. Os seus membros, além de coadjuvarem o mordomo ou imperador nos seus desempemhos cerimoniais - em particular nos que se ligam à coroação - têm ainda uma comparticipação importante nas despesas associadas aos festejos, mediante a entrega - em géneros ou em dinheiro - de uma oferenda tradicionalmente fixada. Em contrapartida, eles constituem um dos destinatários principais das prestações alimentares asseguradas pelo mordomo ou imperador. Ainda em certas freguesia de São Jorge e do Pico, a estrutura básica dos Jantares e das Coroações apresenta também, nas semanas do Pentecostes e da Trindade, um certo número de enriquecimentos. 


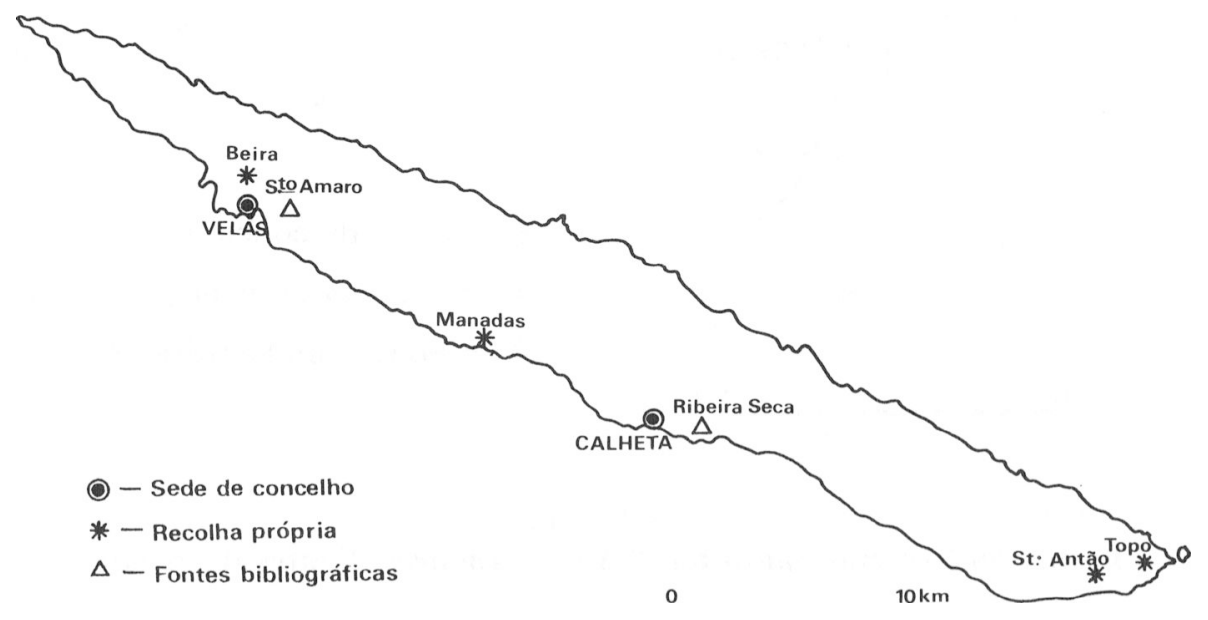

MAPA 10

Festas do Espírito Santo na ilha de São Jorge: Fontes da recolha

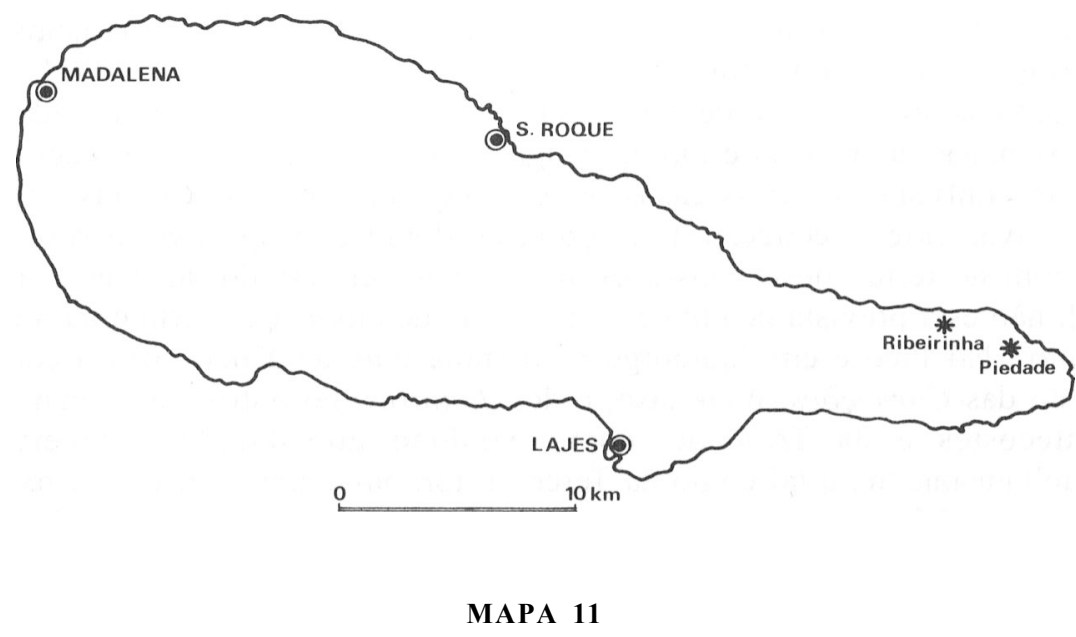

Festas do Espírito Santo na ilha do Pico: Fontes da recolha

Esses enriquecimentos incidem, em primeiro lugar, na vertente propriamente religiosa das festas. A coroação e os cortejos que a rodeiam apresentam geralmente uma maior complexidade cerimonial e, na ilha de São Jorge, são ainda integrados por um certo número de personagens conhecidos pela designação de cavaleiros. A vertente alimentar dos festejos é também mais 


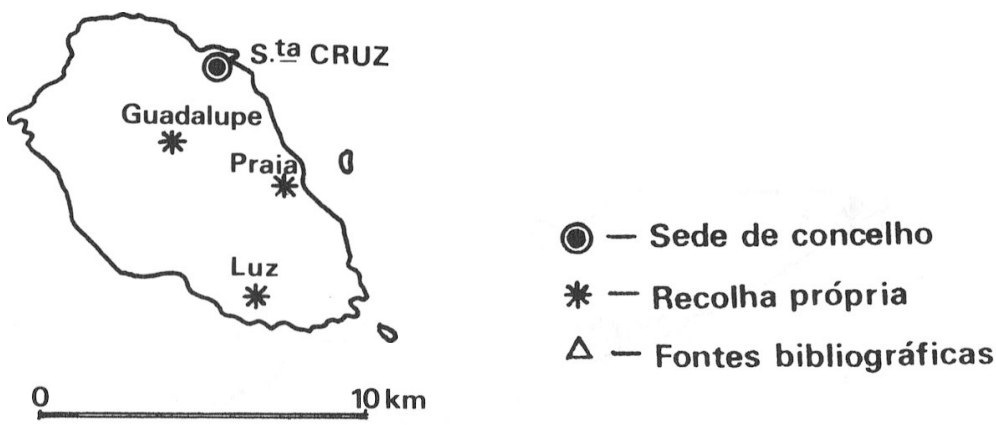

\section{MAPA 12 \\ Festas do Espírito Santo na ilha da Graciosa: Fontes da recolha}

elaborada. Os alimentos são preparados em maiores quantidades e a sua esfera de circulação é mais ampla. Em certos casos, como na ilha de São Jorge, é inclusivamente confeccionado um conjunto variado de doces e sobremesas específicas, variáveis de freguesia para freguesia ${ }^{1}$.

Por fim, há a considerar que, na maioria destas ilhas, é mais notório o movimento de recuo deste primeiro tipo de festejos. Assim, na Graciosa, as Coroações comportam hoje em dia uma vertente exclusivamente religiosa, mesmo nos domingos de Pentecostes e da Trindade. No decurso de cada uma das semanas, as Coroas e outras insígnias do Espírito Santo são sucessivamente confiadas a várias casas, mas a sequência das cerimónias envolve exclusivamente a recitação do terço e, no domingo respectivo, a coroação. Embora no termo desta, possa eventualmente ser servido um lanche informal, não está prevista nenhuma outra forma de circulação cerimonial do alimento $^{2}$. No Pico e em São Jorge predomina uma tendência para a concentração das Coroações, num caso, e dos Jantares, no outro, nas semanas do Pentecostes e da Trindade, com abandono dos domingos anteriores. Simultaneamente, e tal como na Terceira, tornou-se mais corrente a realização — também geralmente por emigrantes — de Coroações e de Jantares ao longo do Verão.

${ }^{1}$ Entre essas sobremesas, destacam-se nas freguesias do Topo e de Santo Antão, além do pão leve, as espécies, as rosquilhas brancas e os suspiros; para mais detalhes cf. p. 203 do Capítulo 9. Nas freguesias da Ribeira Seca e Norte Pequeno, além de alguns dos doces atrás referidos surgem também os fartes $\$ para mais detalhes cf. Soares, Micaela, 1982: 61-62.

2 Esta fraca marcação alimentar das Coroações na Graciosa parece ser recente. Tradicionalmente realizava-se também um jantar (cf. Pacheco, 1986: 30). Hoje em dia, entretanto, as Coroações comjantar realizam-se exclusivamente fora do tempo e estão dependentes de uma promessa específica nesse sentido. 
Quanto ao segundo tipo de festejos, são também importantes as suas similitudes com os Bodos terceirenses. No seu centro encontra-se uma distribuição generalizada de alimentos e vinho, centrada no Império, combinada com arraial, baile, exibições de filarmónicas, arrematações de promessas ao Espírito Santo, etc... Notam-se entretanto diferenças importantes quer quanto ao tipo de alimentos distribuídos, quer quanto à estrutura organizativa dos festejos. $\mathrm{Na}$ Graciosa, os Bodos realizam-se em geral no domingo do Espírito Santo e ainda, em casos isolados, na 2. ${ }^{a}$ Feira do Espírito Santo - caso do Império de Nossa Senhora da Guia, na freguesia da Praia - e no domingo da Trindade - caso do Império de Nossa Senhora dos Remédios, nos Fenais, também na freguesia da Praia - e constam de uma distribuição generalizada de rosquilhas ${ }^{1}$ e vinho. $\mathrm{Na}$ sua base encontra-se um conjunto de irmãos que contribuem para os festejos com uma determinada soma em dinheiro (entre 600 e 1.000 escudos, conforme as freguesias). O produto dessa contribuição é centralizado por uma comissão que assume designadamente o encargo de cozer as rosquilhas e de comprar o vinho para o Bodo ${ }^{2}$. Como contrapartida, cada irmão recebe, além da rosquiIha usual, uma rosquilha maior. No dia imediato ao Bodo, realiza-se ainda uma distribuição porta-a-porta de rosquilhas e de vinho entre os irmãos que, por estarem de luto, não poderam deslocar-se ao recinto da festa. Em São Jorge, por seu turno, os Bodos ou Festas recaem nos domingos do Espírito Santo e da Trindade e, ainda, nalgumas freguesias, na 2. ${ }^{a}$ feira do Espírito Santo. Constam da distribuição generalizada de bolos ou vésperas ${ }^{3}$, de vinho e ainda, em certas freguesias, de tremoços e de fatias de queijo. Nas freguesias da ponte sudeste da ilha - Santo Antão e Topo - os festejos compreendem ainda a realização de um bodo de leite. Na base destas distribuições, encontra-se um conjunto de ofertas feitas por um grande número de casas de cada freguesia, em géneros ou numa quantidade tradicionalmente estipulada de bolos, centralizadas por uma comissão com designação e composição variável de freguesia para freguesia. Em certos casos, as freguesias são para o efeito divididas em duas metades, uma vinculada ao Bodo ou Festa do Espírito Santo, outra vinculada ao Bodo ou Festa da Trindade. No Pico, os Impérios realizam-se no domingo, na 2. ${ }^{\mathrm{a}}$, e, por vezes, na $3 .^{a}$ feira do Espírito Santo e no domingo da Trindade e constam de uma distribuição generalizada de bolos, semelhantes aos utilizados em São Jorge, ou de rosquilhas - também designadas por argolas - e de vinho. A estrutura organizativa das festas é também bastante similar à de São Jorge e assenta em ofertas feitas por casas da freguesia centralizadas por uma comissão nomeada para o efeito. Tal como em São Jorge, é corrente a divisão de cada

\footnotetext{
${ }^{1}$ «As rosquilhas são feitas de trigo e de leite, e não levam açúcar. A massa é dura e, quando se fazem, são marcadas por um chavão que tem o símbolo do Espírito Santo» (Pacheco, 1986: 30).

${ }^{2}$ Tradicionalmente a confecção das rosquilhas competia a cada uma das casas que pretendia contribuir para o Bodo.

${ }^{3}$ Para mais detalhes acerca dos bolos e vésperas, cf., no próximo capítulo, p. 204.
} 
freguesia em duas ou mais circunscrições rituais, que assumem em cada um dos dias, a responsabilidade dos festejos. Estes envolvem, por fim, a realização de cortejos no decurso dos quais os irmãos procedem à entrega cerimonial, em açafates decorados, dos alimentos que serão distribuídos no quadro do Império.

Apesar da relativa difusão que esta variante das Festas do Espírito Santo conhece nas ilhas do grupo central, algumas áreas apresentam entretanto modelos distintos de organização do ritual.

E o que acontece num certo número de freguesias, predominantemente urbanas, da Terceira, onde o Bodo desaparece para dar lugar a uma distribuição porta-a-porta de carne crua de rês, pão e vinho. Esta distribuição tem lugar nos sábados de Pentecostes e da Trindade e incide sobre um conjunto de irmãos - ou irmandade - que contribuem previamente com uma determinada quantia em dinheiro - entre 1.000 e 2.000 escudos. A sua organização está a cargo de um número variável de mordomos ${ }^{l}$. Simultaneamente a esta distribuição de alimentos, os festejos compreendem ainda uma vertente religiosa própria, expressa na organização de grandes coroações colectivas de crianças, geralmente do sexo feminino, escolhidas entre as famílias que pertencem à irmandade: «elas vestem-se de branco e cada criança que vai ser coroada pode convidar duas outras crianças para caminhar a seu lado a fim de ajudar a segurar a coroa. Os rapazes e as raparigas mais velhos, vestidos de cerimónia, transportam as coroas para a igreja» (Salvador, 1981: 76).

\section{III}

As Festas do Espírito Santo no Faial - apesar da colocação geográfica da ilha e das relações muito fortes que ela mantém com a vizinha ilha do Pico - afastam-se em numerosos aspectos da variante dominante nas ilhas do grupo central ${ }^{2}$.

\footnotetext{
${ }^{1}$ Devem ser destacadas as similitudes entre este modelo dos festejos e as variantes prevalecentes em São Miguel e nas Flores e Corvo. Cf. pp. 186 a 189 do presente capítulo.

${ }^{2}$ Os elementos referentes às Festas do Espírito Santo no Faial apoiam-se em recolhas conduzidas nas freguesias do Salão, Cedros, Castelo Branco - onde os festejos possuem actualmente uma expressão muito fraca - e no lugar do Norte Pequeno, freguesia do Capelo (cf. mapa 13). Quanto à bibliografia sobre as Festas do Espírito Santo no Faial limita-se a um estudo geral de características sobretudo históricas (Lima, Marcelino, 1940: 487-505). Esse facto impede que se tirem conclusões quanto ao carácter do actual modelo dos festejos, que representa, como veremos, um tipo pouco corrente no quadro mais geral dos Açores. A hipótese de ele se inscrever num processo de declínio de um modelo inicialmente mais elaborado não deve, entretanto, ser liminarmente excluída.
} 


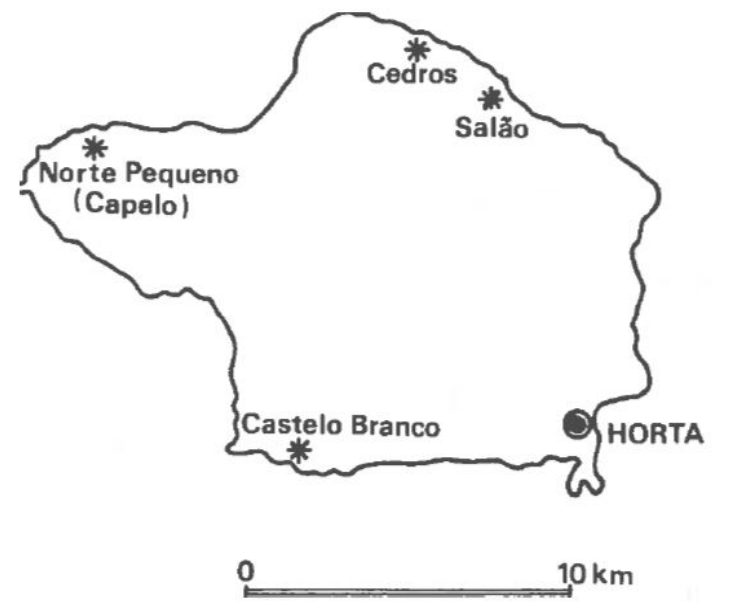

O - Sede de concelho

* - Recolha própria

$\Delta$ - Fontes bibliográficas ${ }^{3}$

MAPA 13

Festas do Espírito Santo no Faial: Fontes da recolha

Nesta ilha, as Festas do Espírito Santo são caracterizadas pela inexistência, pelo menos na actualidade, de quaisquer festejos específicos ao longo das seis semanas que antecedem a semana do Pentecostes. Estes tendem em consequência a concentrar-se no domingo do Espírito Santo, na 2. ${ }^{a}$ e $3 .^{a}$ feiras seguintes e, ainda, em certos casos, no domingo da Trindade.

Na sua base encontra-se um conjunto de irmãos do Espírito Santo organizado em torno de um Império. E entre os irmãos que são escolhidos - de acordo com um sorteio realizado no ano anterior - os responsáveis individuais pelos festejos em cada um dos dias, designados indiferentemente por imperador ou mordomo.

Além de darem o serviço no dia que lhes coube em sorte, os imperadores repartem também entre si a responsabilidade de guardarem em suas casas, durante o ano, a(s) Coroa(s) e outras insígnias do Espírito Santo.

A estrutura básica do cerimonial é relativamente simples e compreende duas cerimónias principais: a coroação, por um lado, e ojantar, por outro. A coroação - rodeada mais uma vez por um conjunto de cortejos organizados para o efeito - - incide sobre o imperador. Ojantar, por seu turno, tem lugar a seguir à coroação e realiza-se, consoante as freguesias, ora na casa do imperador, ora numa copeira situada junto ao Império. Além dos irmãos, participam nele algumas dezenas de convidados do imperador. No seu decurso são servidas Sopas do Espírito Santo, massa sovada e vinho. O essencial da despesa compete ao imperador, que recebe entretanto um contributo - tradicionalmente fixado em dinheiro ou em géneros dos irmãos, assim como outras ofertas de parentes e vizinhos. Em certas freguesias, realiza-se ainda uma distribuição de esmolas, geralmente em massa sovada, entre pobres ou crianças. 


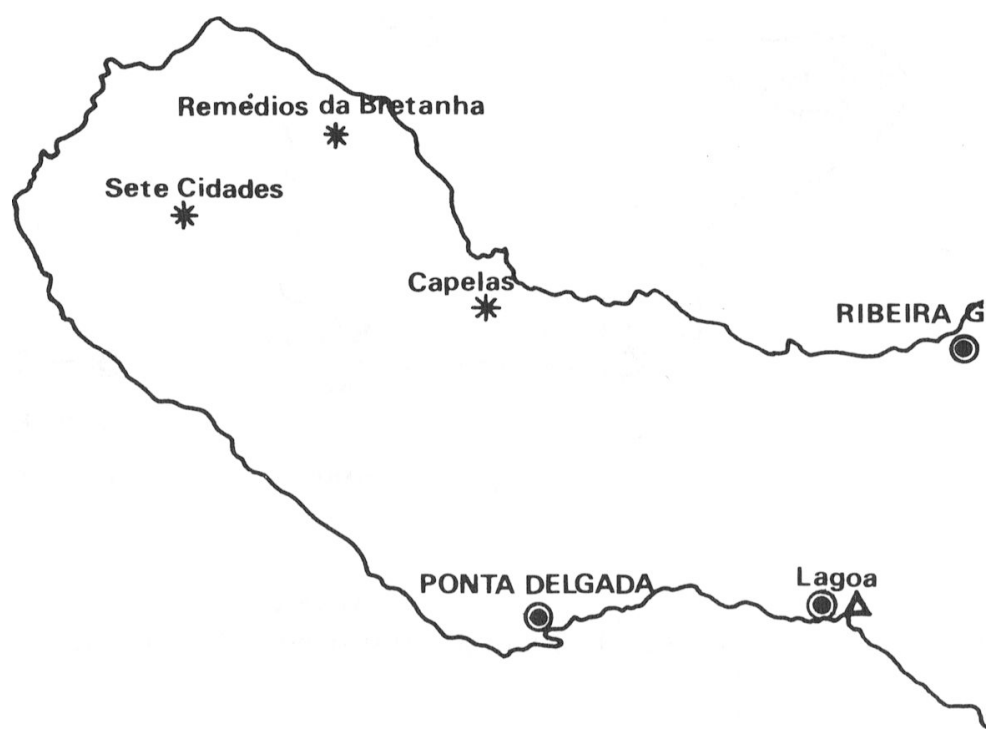

MAPA 14

Festas do Espírito Santo na ilha de São Miguel: Fontes da recolha

IV

Em São Miguel — à semelhança do que ocorre na generalidade das ilhas do grupo central - a estrutura genérica das Festas do Espírito Santo compreende também dois tipos distintos de festejos: as Domingas, que têm lugar ao longo de cada uma das oito semanas que medeiam entre a Páscoa e a 


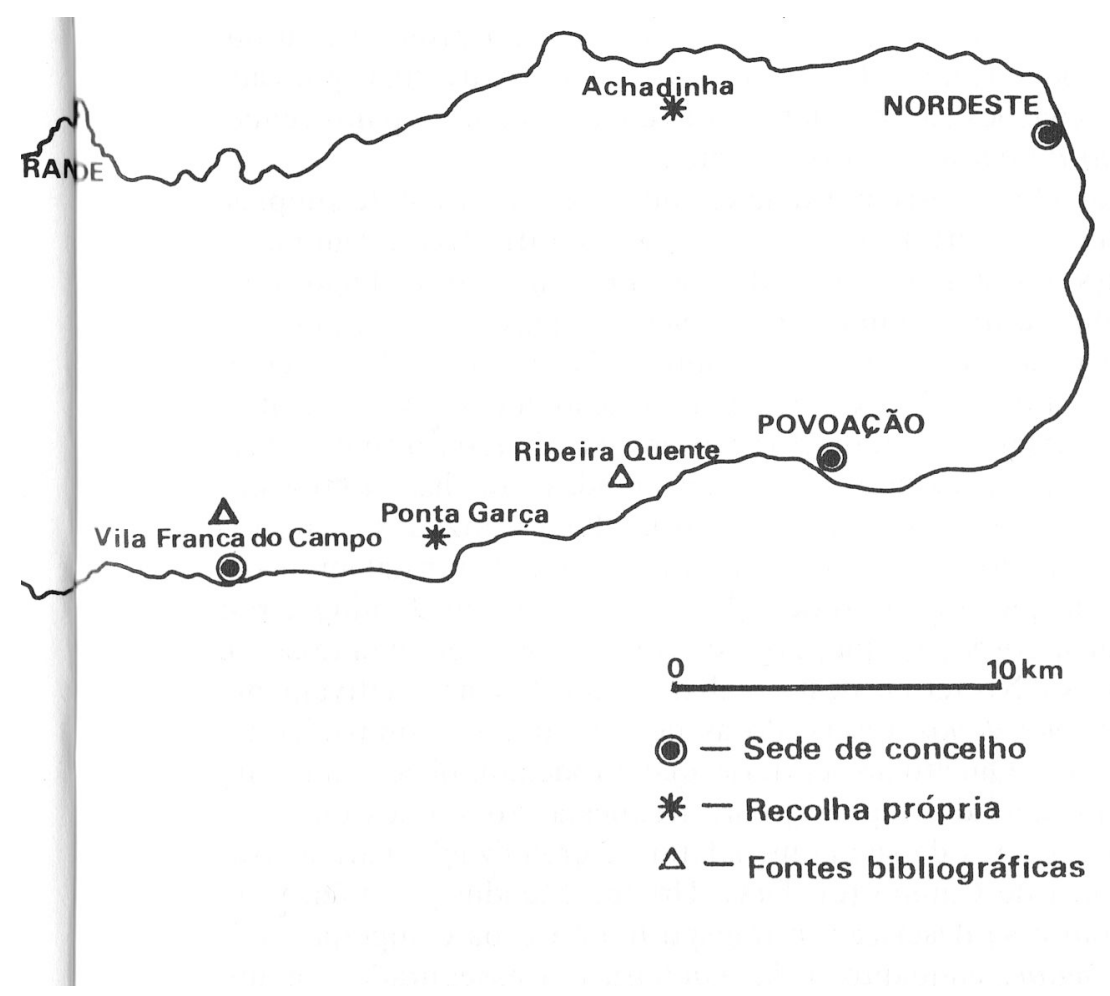

Trindade, e os Impérios, que se realizam no domingo de Pentecostes ou no domingo da Trindade. As modalidades de organização e o conteúdo destes dois tipos de cerimónias apresentam porém diferenças importantes em relação ao modelo prevalecente no grupo central ${ }^{1}$.

${ }^{1}$ Os elementos referentes às Festas do Espírito Santo em São Miguel baseiam-se em recolhas próprias conduzidas nas freguesias das Sete Cidades, Remédios da Bretanha, Capelo, Achadinha e Ponta Garça (cf. mapa 14). Entre a bibliografia disponível destacam-se os estudos de Dias, U. Mendonça (1946: 209-226) - referente sobretudo às freguesias do concelho de Vila Franca do Campo - de Cortes Rodrigues (1924) - freguesia da Ribeira Seca, também no concelho de Vila Franca do Campo - e de Tavares (1979) - referente ao concelho da 


\section{AS FESTAS DO ESPÍRITO SANTO NOS AÇORES}

Na base tanto das Domingas como dos Impérios encontra-se uma irmandade de características informais integrada idealmente pelo conjunto das casas correspondentes a uma freguesia ou a diferentes lugares de uma mesma freguesia. Cada irmandade está ligada a um teatro — ou Império - que possui uma ou mais Coroas, assim como outras insígnias do Espírito Santo: bandeiras, e, em certas freguesias, um espadim.

É entre os irmãos que se oferecem para o efeito — por promessa ou por devoção - que são anualmente sorteados os responsáveis individuais por cada Dominga, cujas designações são bastante variáveis de freguesia para freguesia: mordomo, irmão da coroa, imperador, etc...

As Domingas caracterizam-se por uma estrutura particularmente simples, marcada pela ausência de prestações alimentares significativas. Durante a semana, a(s) Coroa(s) e outras insígnias do Espírito Santo são instaladas em casa do mordomo, num altar erguido especificamente para o efeito, junto do qual era tradicional rezar-se ou cantar-se o terço. Estes altares distinguem-se, no quadro mais geral dos Açores, pela sofisticação que têm vindo a atingir nos últimos anos. Além de uma utilização profusa de todo o tipo de elementos decorativos - flores naturais e artificiais, rendas e toalhas, decorações natalícias, «bibelots» de todo o género - são também utilizados dispositivos especiais de iluminação e, por vezes, há mesmo casas que instalam mecanismos que permitem que o altar rode sobre si próprio. No domingo, por seu turno, tem lugar a coroação que, hoje em dia, incide geralmente sobre uma ou mais crianças ${ }^{1}$. No termo desta realiza-se um lanche relativamente informal em casa do mordomo, reservado às pessoas que o acompanharam no decurso da coroação. Quanto aos cortejos que a rodeiam, obedecem a um padrão tradicional variável de freguesia para freguesia. Possuímos uma boa descrição de alguns aspectos da sua nomenclatura e organização para as freguesias de Vila Franca do Campo (cf. Dias, Urbano Mendonça, 1946: 218-222). De acordo com essa descrição, o transporte da Coroa competia tradicionalmente a um vedor, enquanto o da bandeira era assegurado por um alferes da bandeira. O espadim, pelo seu lado, estava a cargo do chamado condestável ou pagem do estoque e existia ainda um pagem do coxim «que levava à igreja a almofada onde ajoelhava o imperador» (id., ibid.: 220).

Lagoa. Embora com características mais genéricas veja-se também Nogueira, 1894, 45-50; Lima, Gervásio, 1932, 79-92; Dias, Tenente Francisco J., 1981, 51-63 e Pavão, 1981, 272-276. Estes três últimos textos contêm sobretudo informação referente aos cantares usados pelas folias no decurso das Festas do Espírito Santo. Entre os materiais de Leite de Vasconcelos publicados postumamente existem também algumas notas soltas àcerca das Festas do Espírito Santo em São Miguel (1982: 345-346 e 349).

${ }^{1}$ Nalguns casos, é esta criança que recebe a designação de imperador (cf. Dias, U. Mendonça 1946: 217; Cortes Rodrigues, 1924: 306). Pelo seu lado, Mendonça Dias refere também ser do seu tempo « ser coroado e andar em acto processional pelas ruas um velho, um pobre, vestido no seu melhor fatito, mas um miserável no entanto» (id., ibid.). 
Finalmente, o transporte das varas com que no termo da coroação era formado o quadrado que rodeava o imperador coroado competia a quatro senhores das varas.

Os Impérios, por seu turno, são caracterizados por uma distribuição de alimentos que, em vez de assumir características abertas e públicas, intervêm exclusivamente junto de cada uma das casas da irmandade. Esta distribuição consta em geral de uma posta de carne crua de rês, de um pão de trigo e, ainda, em certos casos, de um pão de massa sovada e de um litro de vinho. A designação mais corrente atribuída a esta prestação é a de pensão. Em certas freguesias, para além destas pensões, são ainda distribuídas prestações de natureza similar, mas em quantidades diferentes, conhecidas por meias pensões, esmolas, presentes, etc...

O financiamento desta distribuição - que pode envolver, nos casos mais expressivos, o abate de dezassete a vinte reses e o dispêndio de quantidades importantes de farinha, açúcar, ovos, vinho, etc... - assenta, por um lado, na contribuição monetária dos irmãos, cujo valor pode ir hoje em dia até $5.000 \$ 00$ e, por outro, nas receitas próprias do Império, entre as quais avultam as resultantes da arrematação de um certo número de reses adquiridas previamente para o efeito. Quer estas reses, quer aquelas que são abatidas para distribuir entre os irmãos, são mantidas e engordadas por um certo número de criadores que, por devoção, se oferecem para o efeito. Quanto à preparação dos alimentos, assim como outros aspectos relacionados com a organização geral dos festejos, a sua responsabilidade recai ora sobre um dispenseiro ou depositário nomeado expressamente para o efeito, ora sobre o mordomo da Dominga que coincide com o Império. Em qualquer dos casos, o responsável pelos festejos é auxiliado por um numeroso grupo de homens e mulheres que repartem entre si as diferentes tarefas, nomeadamente de natureza culinária. Entre estas merece particular realce o abate das reses, que é rodeada - como nas ilhas do grupo central — de uma certa cerimonialização.

A distribuição das pensões realiza-se, consoante os Impérios, no sábado de Pentecostes ou no sábado da Trindade e era tradicionalmente feita porta-a-porta, com acompanhamento da(s) Coroa(s) e da folia, em carros de bois especificamente decorados para o efeito. Hoje em dia, porém, em certos casos, são já os próprios irmãos que se dirigem ao local onde a carne está guardada, para levantarem a sua pensão.

Além desta distribuição central de alimentos, a estrutura ritual dos Impérios prevê ainda um certo número de outras cerimónias, entre as quais avulta uma refeição de características rituais - a chamada Ceia dos Criadores - que reúne, em dias variáveis de freguesia para freguesia, o dispenseiro ou o mordomo, os criadores e ainda o conjunto dos ajudantes do Império. No domingo, por seu turno, têm lugar, junto ao teatro - onde a(s) Coroa(s) se conservam durante o dia - um certo número de festejos: arraial, arrematação de promessas ao Espírito Santo, etc... 
Nas Flores e Corvo, a par de um certo número de similitudes com o modelo prevalecente em São Miguel, as Festas do Espírito Santo apresentam um conjunto de traços próprios ${ }^{1}$.

A estrutura genérica dos festejos assenta na distinção entre Domingas, ou Semanas - que se realizam ao longo das oito semanas que medeiam entre a Páscoa e a Trindade - e Impérios - que recaem no domingo de Pentecostes ou no domingo da Trindade. Na base de ambos os festejos encontra-se uma irmandade, centrada numa Casa do Espirito Santo, que possui uma ou mais Coroas, assim como um certo número de bandeiras. A frente de cada irmandade encontra-se um número variável de cabeças — também designados em certas freguesias por cabeceantes - escolhidos de acordo com critérios variáveis de freguesia para freguesia.

As Domingas obedecem a dois modelos organizativos distintos. Nas freguesias do norte da ilha - numa área «grosso modo» correspondente ao concelho de Santa Cruz - eles filiam-se no modelo mais comum nos Açores: à sua frente encontra-se um imperador que, durante a semana que lhe coube em sorte, instala a(s) Coroa(s) em sua casa, assumindo a responsabilidade pelo conjunto de cerimónias tradicionalmente previsto. Nas freguesias do sul das Flores - concelho das Lajes - essa responsabilidade é por seu turno assegurada, em cada uma das oito semanas, pelos cabeças da irmandade, tendo os festejos lugar na Casa do Espírito Santo.

A estrutura propriamente cerimonial das Domingas é, entretanto, em ambos os casos, similar. Durante a semana, têm lugar, num certo número de dias tradicionalmente fixados - geralmente $3 .^{\text {as }}$ feiras, $5 .^{\text {as }}$ feiras e sábados, à noite - as alvoradas. Estas constam basicamente de um conjunto de cantares entoados pela folia junto ao altar do Espírito Santo. Esses cantares alguns dos quais variam consoante o dia da alvorada, e, por vezes, consoante a própria semana - tratam temas de natureza predominantemente religiosa e possuem um carácter tradicional muito vincado ${ }^{2}$. Em cada um dos domingos, por seu turno, as Coroas são levadas à igreja, isto é são cerimonialmente transportadas, à hora da missa, à igreja, finda a qual retornam para

A recolha acerca das Festas do Espírito Santo nas Flores incidiu sobre as freguesia das Lajes, Fajã Grande, Santa Cruz - Vila e lugar da Fazenda - e Ponta Delgada (cf. mapa 15). A bibliografia disponível inclui, além do estudo clássico de Francisco Chaves (1904), os textos mais recentes do etnólogo francês Daniel-Francis Laurentiaux (1979; 1983). Trata-se, em ambos os casos de estudos de carácter genérico. Em Leite de Vasconcelos (1982: 340-345) pode encontrar-se também um pequeno apontamento de carácter genérico sobre as Festas do Espírito Santo nas Flores. Finalmente em Legoupil ( $\mathrm{s} / \mathrm{d}$ : 154-159), existe uma secção consagrada às Festas do Espírito Santo na Vila das Lajes.

${ }^{2}$ Para uma descrição mais detalhada das alvoradas cf. Chaves, 1904: 17-35. 

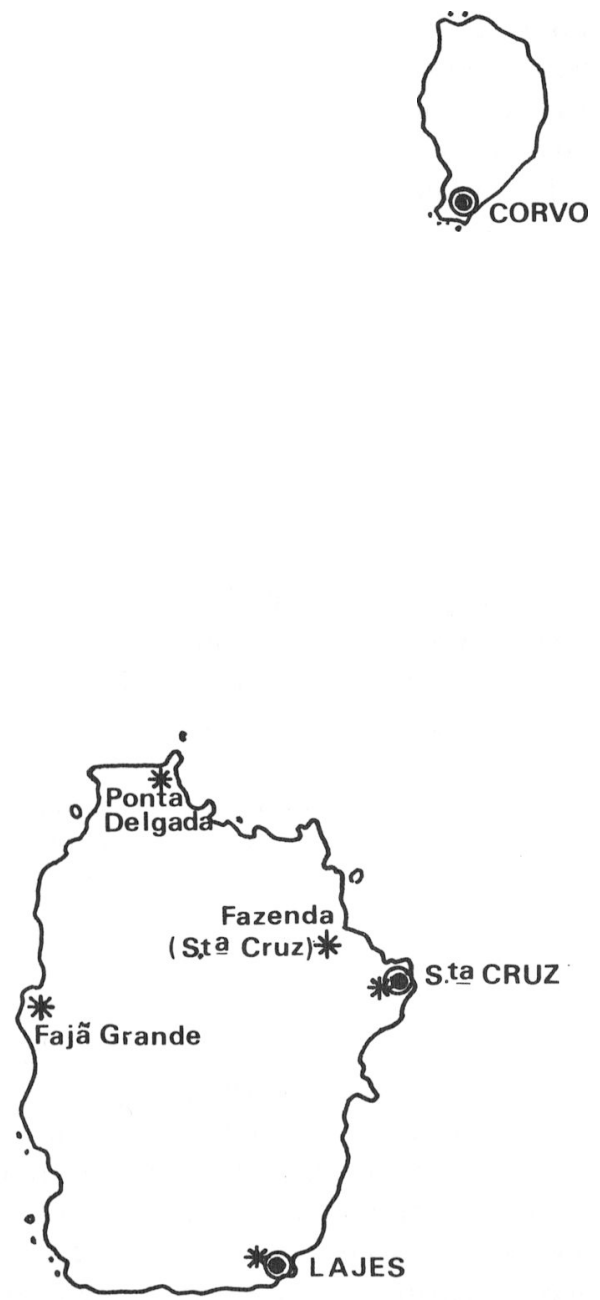

$$
\begin{aligned}
& \text { - Sede de concelho } \\
& \text { * - Recolha própria } \\
& \Delta \text { - Fontes bibliográficas }
\end{aligned}
$$

MAPA 15

Festas do Espírito Santo nas Flores e Corvo: Fontes da recolha

casa do imperador ou para a Casa do Espírito Santo. Não se realiza porém a coroação; de facto, esta, enquanto prática regular e institucional é desconhecida nas Flores. Apesar deste facto - inédito no conjunto dos Açores, onde a coroação constitui sempre uma das sequências centrais das Festas do 
Espírito Santo - esta pequena cerimónia é rodeado de um aparato similar àquele que encontrámos noutras ilhas. A frente dos cortejos segue a folia, seguindo-se-lhe as bandeiras, e, por fim, as Coroas. As primeiras são transportadas por um ou mais alferes da bandeira, enquanto as Coroas estão a cargo de um ou mais reis da Coroa. Tradicionalmente, estes desempenhos eram assegurados por homens feitos, mas hoje em dia são sobretudo crianças ou adolescentes os preferencialmente escolhidos.

Em caso de promessa, as Domingas podem ainda envolver, para além das cerimónias religiosas que acabámos de passar em revista, uma vertente alimentar. Esta pode assumir duas modalidades principais: a) o jantar cozido, cuja prestação central é constituída por uma refeição colectiva, à base de Sopas do Espirito Santo, massa sovada e vinho, reservada aos convidados do imperador ou extensiva ao conjunto da freguesia e a eventuais forasteiros; b) o jantar cru, em que avulta uma distribuição porta-a-porta de carne crua de rês e de pão de trigo a um certo número de casas escolhidas pelo imperador. Tal como sucede na generalidade dos Açores, embora um certo número destes jantares se continue a realizar no período tradicionalmente previsto para o efeito, a maior parte tem lugar ao longo do verão.

Os Impérios, por seu turno, recaem, consoante as freguesias e/ou lugares, ora no domingo de Pentecostes, ora no domingo da Trindade e, tanto nas freguesias do sul da ilha como nas do norte, centram-se na Casa do Espirito Santo e estão a cargo dos cabeças.

No plano religioso, a sua estrutura é idêntica à das domingas: às $3 .^{\text {as }}$ feiras, 5. ${ }^{\text {as }}$ feiras e sábados realizam-se as alvoradas e, no domingo as Coroas são levadas à igreja, por intermédio de um cortejo organizado em moldes similares aos referidos atrás, mas cuja composição é mais sofisticada: além de uma filarmónica, integram-se nele algumas dezenas de meninas vestidas de branco, entre as quais são escolhidas as rainhas dafesta, encarregues do transporte das Coroas. Simultaneamente têm lugar um conjunto de festejos suplementares, com relevo para uma distribuição de carne crua de rês entre todos os membros da irmandade. As prestações distribuídas possuem designações variáveis de freguesia para freguesia - enfiadas, oitavas, mordomos, etc... - e retribuem uma contribuição monetária feita previamente pelos irmãos, cujo valor oscila entre os 2.500 e os 3.000 escudos. Tal como em São Miguel, esta distribuição tem lugar a um sábado e dava tradicionalmente lugar à organização de um cortejo que percorria as casas de todos os irmãos. Dirigido musicalmente pela folia, esse cortejo era integrado pelas Coroas e por dois ou três carros de bois decorados, que asseguravam o transporte da carne. Em cada uma das casas, além de procederem à entrega da carne, os cabeças davam ainda a Coroa a beijar às pessoas presentes e recebiam qualquer eventual oferta ao Espírito Santo que a casa quisesse fazer - batatas ou outros géneros agrícolas, massa sovada, etc... Nas casas dos cabeças, alferes da bandeira e reis da Coroa, tinham lugar paragens mais demoradas: afolia entrava e can- 
tava e os acompanhantes do cortejo eram convidados e servir-se de uma mesa posta para o efeito. Pese embora o facto de na maioria dos Impérios a distribuição de carne ser já assegurada em moldes diferentes - cada irmão levanta individualmente a sua prestação na Casa do Espirito Santo - os restantes aspectos deste cortejo têm-se mantido intactos. No domingo, por seu turno, os festejos compreendem ainda a realização de um arraial e a arrematação de promessas. Nalgumas freguesias tem também lugar um cerimonial conhecido pela designação de dispender o bodo, que consiste no oferecimento formal ao Espírito Santo das promessas recolhidas na véspera, seguido de uma eventual repartição, entre as pessoas presentes, de algumas fatias da massa sovada oferecida.

\section{VI}

As sucessivas variantes das Festas do Espírito Santo que passámos em revista expressam a diversidade de soluções que caracteriza o ritual em todo o arquipélago. Trata-se de um traço frequentemente sublinhado tanto pelos etnógrafos como pelos próprios protagonistas do ritual. A expressão «A cada canto/seu Espírito Santo» - frequentemente utilizada por estes últimos remete justamente para esta faceta das Festas do Espírito Santo no arquipélago. Entretanto, a par desta diversidade, é possível reconhecer às Festas do Espírito Santo uma grande unidade. Por detrás das variações que tivemos ocasião de reconstituir, reencontramos, estruturados de forma diferente, os mesmos grandes motivos etnográficos. A longa duração dos festejos e a sua complexidade cerimonial, o modo como a sua organização resulta da articulação de formas de mordomia individual com modalidades de intervenção mais ampla da comunidade, o carácter central que neles ocupa um conjunto de cerimónias religiosas estruturadas em torno da Coroa do Espírito Santo, a articulação desta vertente mais estritamente religiosa do ritual com um conjunto amplo e diversificado de formas de circulação cerimonial do alimento, são os aspectos principais desse fundo etnográfico comum aos festejos.

Por detrás desta unidade propriamente etnográfica, perfila-se uma unidade mais profunda, referente às grandes ideias estruturadoras do ritual. Tivemos ocasião de proceder, na primeira parte do livro, em torno dos Impérios de Santa Bárbara, a uma análise dessas ideias. Salientámos então as características religiosas das Festas, e o modo como elas articulavam entre si formas de religiosidade de características individuais com formas de religiosidade de natureza colectiva. Vimos também como, simultaneamente, os Impérios se entregavam a um importante trabalho de reiteração das relações sociais assente nas potencialidades significantes da linguagem da dádiva alimentar - que, começando por dizer respeito às esferas sociais de cada um dos impe- 
radores - parentesco, vizinhança de perto — se estendia, num segundo e decisivo momento, às instâncias centrais da organização social local — o lugar e, sobretudo, a freguesia. Finalmente, tivemos ocasião de acentuar as características cíclicas dos Impérios, a sua ligação não apenas a ideias de renascimento da natureza mas de reorganização e regeneração das relações sociais. São justamente estes grandes temas, formulados de forma diferente consoante os contextos, que podemos encontrar no conjunto do arquipélago. É precisamente a uma demonstração mais detalhada desta dialéctica entre diversidade e unidade que iremos proceder nos próximos capítulos, baseados em dois estudos de casos conduzidos nas freguesias de Santo Antão (São Jorge) e Nossa Senhora da Piedade (Pico). 


\section{CAPÍTULO 9}

JANTARES, GASTOS E FESTAS

SANTO ANTÃo (SÃO JORGE) 
Santo Antão é uma das cinco freguesias que compõem o concelho da Calheta, na ilha de São Jorge. Situada na ponta SE da ilha, a freguesia integra, juntamente com a freguesia do Topo, uma área geográfica com características relativamente individualizadas no conjunto da ilha.

Com um área de 33,41 km2, a freguesia possuía em 1988 um total de 1.225 habitantes e 294 grupos domésticos. Destes, cerca de $72 \%$ correspondiam a agregados familiares simples, $16 \%$ a agregados familiares alargados e $3 \%$ a agregados familiares múltiplos; os «isolados» representavam $8 \%$ das unidades domésticas e, por fim, os agregados não conjugais correspondiam a $1 \%{ }^{1}$.

A população distribui-se por um conjunto de lugares - localmente designados por arrabaldes - entre os quais, se destacam, para além do centro propriamente dito, os lugares de São Tomé, Cruzai, Caminho Chão e Santa Rosa. Caracterizados por uma maior dimensão demográfica, dispondo também, em muitos casos, de um conjunto de equipamentos próprios - comércio, escolas, ermidas, etc... - estes lugares são considerados os mais importantes da freguesia. Além deles existem ainda - como se depreende do quadro 23 - um conjunto de outros lugares que, embora individualizados por topónimos próprios, acabam por se referenciar privilegiadamente aos lugares atrás mencionados. No litoral norte e sul situam-se por seu turno um certo número de povoações de ocupação temporária, os chamados nortes oufajãs, a mais importante das quais é a Fajã de São João.

O povoamento oscila entre o povoamento disperso puro e o povoamento disperso-orientado, estruturado em torno de canadas ou caminhos, ao longo dos quais se dispõem as casas. Na sequência do sismo de 1981, ao mesmo tempo que se acentuou o peso deste último tipo de povoamento, ocorreu uma profunda modificação nos padrões da casa tradicional, que se encontra em franco declínio.

\footnotetext{
${ }^{1}$ Estes números baseiam-se num recenseamento das casas da freguesia, efectuado a partir dos registos paroquiais e completado com a recolha de informação oral.
} 


\section{LUGARES}

Santa Rosa

Ribeirinha

Cancelinha

Santo Antão

Canada do Atalho

Bueiro

Canada do Canto

Sete Fontes

Caminho Chão

Canada da Castanha

Canada das Queimadas

Cruzai

Caminho de Cima

Canada do Foro

Canada da Caldeira

Lameiro

Tranqueiras

São Tomé

Fajã de São João

Totais
UNIDADES
DOMESTICAS

30

13

24

32

5

8

8

5

18

5

2

62

9

4

8

11

6

38

6

294
HABITANTES

101

66

107

125

18

32

35

27

70

13

19

234

40

9

21

55

37

194

22

1225

QUADRO 23

Distribuição da população por lugares (Santo Antão, 1988)

Tal como outras freguesias açorianas, Santo Antão é uma freguesia marcada pela emigração, em particular pelo surto migratório que se desenvolveu a partir dos anos 60: a sua população actual representa cerca de $64 \%$ da população existente na freguesia em 1960 ${ }^{1}$. Essa emigração apresenta entretanto características algo diferentes das que observámos em Santa Bárbara: dirige-se na sua esmagadora maioria para a costa oeste dos Estados Unidos da América sendo a ocupação profissional dominante entre os emigrantes o trabalho em grandes explorações agrícolas ligadas à criação de gado leiteiro.

\footnotetext{
${ }^{1}$ Segundo os dados do Recenseamento Geral da População de 1960, a população da freguesia era nesse ano de 1933 habitantes, correspondentes a 520 fogos.
} 
A economia da freguesia é essencialmente pastoril e desenvolve-se em torno da criação de gado vacum. O total do efectivo pecuário da freguesia era em 1985 de cerca de 2.200 cabeças de gado, com predomínio das vacas leiteiras, correspondentes a $40 \%$ do total ${ }^{1}$. Esta orientação pastoril, embora venha de trás, conheceu, a partir dos anos 40/50, uma aceleração decisiva, em detrimento de uma certa complementariedade até então existente entre a criação de gado e actividades de características mais estritamente agrícolas. Assim, actualmente, embora cada casa disponha de terrenos destinados a culturas agrícolas - milho, batata, vinha, produtos hortícolas diversos - , cerca de $88 \%$ da Superfície Agrícola Útil da freguesia - 1.335 ha - corresponde a pastos. O próprio milho - que ocupa uma área de 105 ha - destina-se hoje em dia maioritariamente à alimentação do gado.

A estrutura da propriedade baseia-se na pequena e média propriedade muito dispersa. O número médio de blocos por exploração é de 7,4, sendo a área média por bloco de 0,82 ha. $\mathrm{O}$ arrendamento - pago num quantitativo determinado de leite - ocupa um lugar importante na estrutura fundiária local, correspondendo as terras arrendadas a cerca de $42 \%$ do total da Superfície Agrícola Útil.

A criação de gado destina-se essencialmente à produção de leite, utilizado no fabrico do queijo de São Jorge, sendo portanto relativamente significativa a orientação da economia local para o mercado. $60 \%$ das explorações agrícolas retiram o seu rendimento principal ou exclusivo da actividade pecuária, e é de $88 \%$ a percentagem de explorações agrícolas que vendem regularmente parte da sua produção. A venda do leite e o fabrico do queijo processam-se no âmbito da Cooperativa Agrícola do Topo, que abrange as freguesias de Santo Antão e do Topo. Fundada em 1944, a Cooperativa dispõe desde 1986 de modernas instalações fabris situadas na Ribeira das Lexivias, em Santo Antão. O seu número total de sócios era, em 1987, de 303, 193 dos quais eram moradores de Santo Antão. O total de leite processado pela fábrica elevou-se, em 1987, a cerca de 2.769 milhões de litros, sendo a sua produção no mesmo ano de perto de 26.000 queijos grandes ${ }^{2}$.

\section{II}

Em Santo Antão, as Festas do Espírito Santo compreendem, como nas ilhas do grupo central, duas séries distintas de festejos: os Jantares e os Gastos,

\footnotetext{
${ }^{1}$ Estes dados e os seguintes baseiam-se nos resultados do Recenseamento Agrícola dos Açores de 1985 relativos a Santo Antão.

${ }^{2}$ Os dados referentes à Cooperativa Agrícola do Topo foram-me fornecidos pela respectiva direcção, na altura presidida pelo Sr. José Leovigildo.
} 


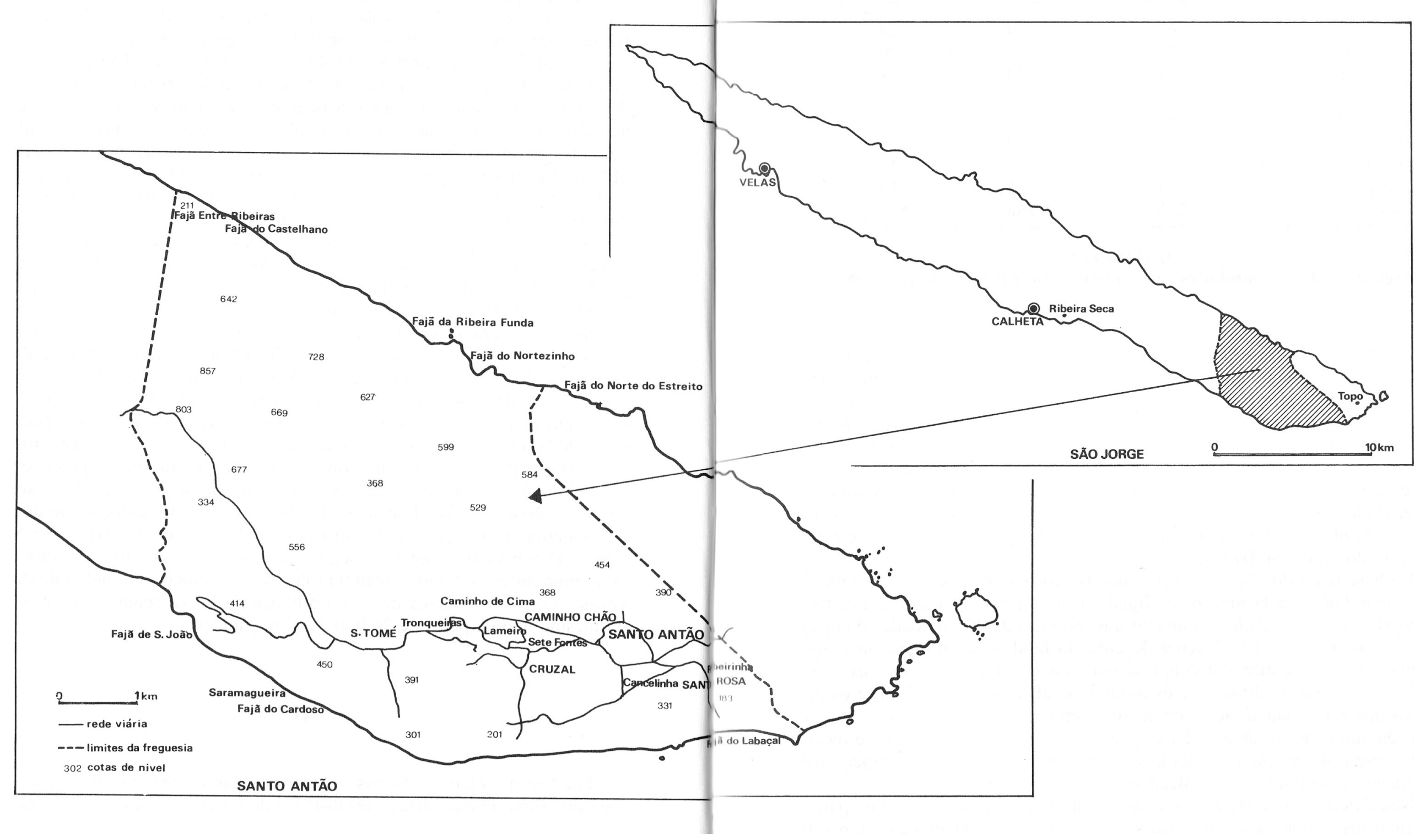

MAPA 16

Freguesia de Santo Antão 
AS FESTAS DO ESPÍRITO SANTO NOS AÇORES

\begin{tabular}{lccc}
\hline IRMANDADE & N. ${ }^{\circ}$ MEMBROS & IRMÃOS & AJUDANTES \\
\hline 1. Jantar & 37 & 14 & 23 \\
2. Jantar & 35 & 15 & 20 \\
3. Jantar & 31 & 13 & 18 \\
4. Jantar & 32 & 16 & 16 \\
5. Jantar & 51 & 51 & - \\
6. Jantar & 30 & 24 & 6 \\
Gasto Pentecostes & 45 & 13 & 32 \\
Gasto Trindade & 34 & 22 & 12 \\
Total & $\mathbf{2 9 5}$ & $\mathbf{1 6 8}$ & $\mathbf{1 2 7}$ \\
\hline
\end{tabular}

\section{QUADRO 24}

Membros das irmandades do Espírito Santo (Santo Antão, 1988)

por um lado, e as Festas, por outro. Os Jantares e os Gastos - equivalentes às Funções terceirenses - têm lugar ao longo do período de oito semanas que medeia entre o domingo de Páscoa e o domingo da Trindade. Nas primeiras seis semanas têm lugar os Jantares, conhecidos por primeiro Jantar, segundo Jantar, terceiro Jantar, etc..., de acordo com a semana em que recaem. Nas últimas duas semanas têm lugar os Gastos: Gasto do Espírito Santo ou de Pentecostes no domingo de Pentecostes e Gasto da Trindade, no domingo da Trindade. Nestas duas últimas semanas, em simultâneo com os Gastos realizam-se também as Festas: Festa velha, no domingo de Pentecostes e Festa nova, no domingo da Trindade.

$\mathrm{Na}$ base tanto dos Jantares como dos Gastos encontra-se um conjunto de oito irmandades, cada uma delas ligada a um Jantar ou Gasto específico. No total, estas irmandades abrangem um conjunto de 295 unidades domésticas, 84 das quais - isto é cerca de $28 \%$ do total - correspondem a emigrantes. Os seus membros dividem-se em duas categorias: os cabeças - ou irmãos propriamente ditos - e os ajudantes (cf. quadro 24). É entre os primeiros que cada irmandade - de acordo com um critério rotativo - designa em cada ano o responsável individual pelos festejos respectivos. Este recebe a designação de mordomo e, apoiado na irmandade, assume um papel particularmente importante no seu decurso.

Nos Jantares os festejos convergem, em cada uma das semanas, para o domingo respectivo, sendo a semana que o antecede ocupada com preparativos de vária ordem e com algumas cerimónias preliminares. Nos Gastos, o ponto culminante dos festejos, além do domingo, abrange ainda os dias mais próximos: sábado, 2. ${ }^{\mathrm{a}}$ e $3{ }^{\text {a }}$ feira, no caso do Gasto de Pentecostes e sábado, no Gasto da Trindade. A estrutura genérica dos festejos apresenta um certo número de traços comuns. Nos Gastos, de acordo com a sua maior extensão, 


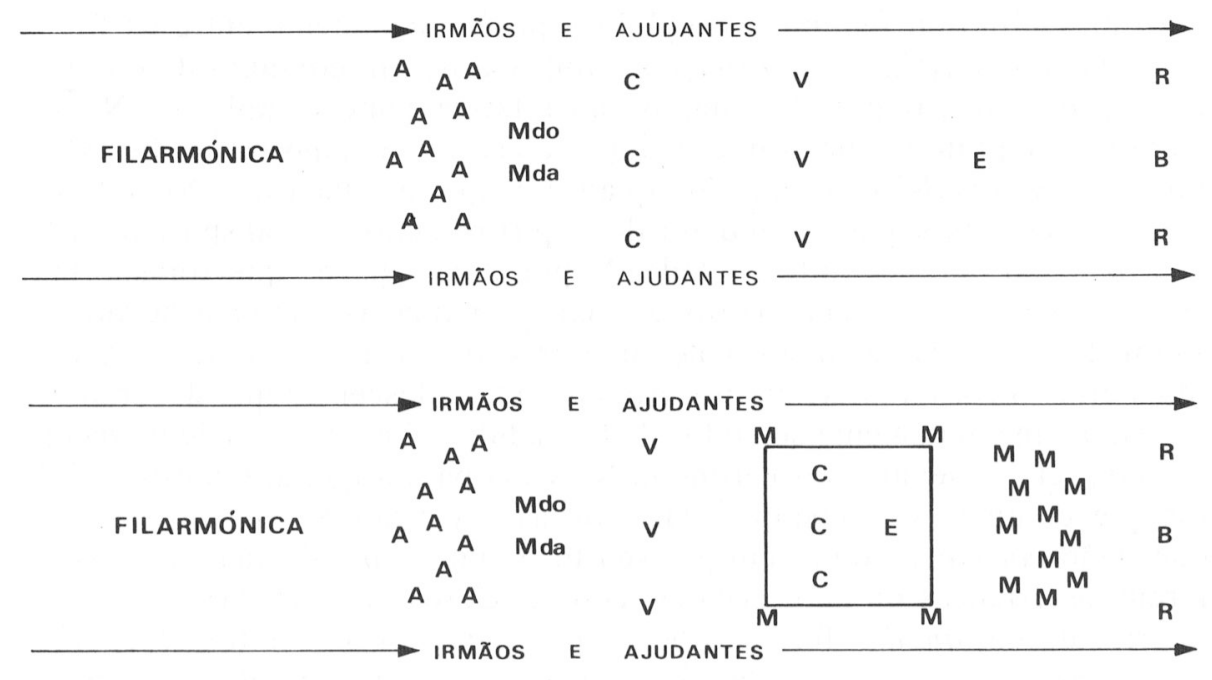

FIGURA 8

Organização dos cortejos que antecedem e se seguem à coroação (Santo Antão)

Legenda: R - ramos; B - bandeira do Espírito Santo; E - espadim; V - varas; $\mathrm{C}$ - coroas; Mdo/Mda - mordomos; A - acompanhantes; $\mathrm{M}$ - crianças

essa estrutura básica é entretanto objecto de um conjunto significativo de enriquecimentos e acrescentamentos.

$\mathrm{Na}$ sua vertente religiosa, os festejos compreendem, em primeiro lugar, a recitação diária do terço. Esta tinha tradicionalmente lugar em casa do mordomo, onde no decurso da semana preparatória dos festejos, eram instaladas as insígnias do Espírito Santo - três Coroas, uma bandeira e um espadimEntretanto, desde há cerca de 20/30 anos essa prática entrou em declínio e a recitação diária do terço tem actualmente lugar no Império. Diferentemente do que se passa noutras ilhas do grupo central, este terço não apresenta características tradicionais específicas: trata-se de um terço usual, marcado pelo peso que nele assumem as intenções relacionados com o mordomo e sua família. No domingo, no termo da missa, tem por seu turno lugar a coroação. Esta incide sobre três crianças ou adolescentes, do

\footnotetext{
1 Das três Coroas existentes na freguesia, uma é mais antiga, sendo considerada como a Coroa primitiva do Império. Quanto às duas restantes, uma delas pertencia originalmente à ermida do Norte de Entre-Ribeiras, destruída pelo sismo de 1981, e a outra foi oferecida ao Império, nos anos 40, por um emigrante.
} 
sexo masculino ou feminino, escolhidos preferencialmente entre os filhos ou filhas do mordomo. A coroação é rodeada de um conjunto de cortejos que obedecem a regras de composição relativamente complexas. Nesses cortejos integram-se em primeiro lugar duas alas compostas pelos membros da irmandade, cada um dos quais transporta uma vara. No interior dessas duas alas segue a bandeira do Espírito Santo - transportada pelo mordomo do ano seguinte - ladeada por dois rapazes que transportam consigo os ramos - duas varas especiais encimadas por uma decoração floral. Em seguida segue a criança que procede ao transporte do espadim. Mais atrás incorporam-se as três crianças ou adolescentes que deverão ser coroados, imediatamente seguidos de três adultos, encarregues de os secundar nos seus desempenhos cerimoniais. A ida para a igreja, é a estes adultos que compete o transporte das Coroas; as crianças ou adolescentes que serão coroados conduzem por seu turno uma vara florida. A saída da igreja, as crianças ou adolescentes, com as Coroas na cabeça, seguem no interior de um quadro formado por varas enquanto os adultos asseguram o transporte das varas floridas. E usual incorporarem-se então no cortejo algumas dezenas de crianças, geralmente vestidas de branco e transportando consigo ramos de flores, que acompanham o quadro das Coroas. Encerrando esta secção do cortejo seguem por fim o padre, o mordomo e a mordoma, bem como alguns acompanhantes. Tradicionalmente, o acompanhamento destes cortejos — bem como de outras sequências dos festejos - cabia a uma folia, composta por um tambor e por um cantador. Entretanto - de acordo com uma tendência mais geral que tivémos anteriormente ocasião de pôr em evidência - a folia entrou em declínio, sendo actualmente o acompanhamento dos festejos assegurado por uma das duas filarmónicas existentes na freguesia, que segue usualmente no termo do cortejo (cf. figura 8).

Nos Gastos esta estrutura ritual reveste formas mais complexas. Assim, em vez de uma, realizam-se várias coroações, ao longo dos diferentes dias por que os festejos se prolongam. Geralmente, quer as crianças ou adolescentes que coroam, quer os adultos que os acompanham são distintos de coroação para coroação. Por outro lado, os cortejos que rodeiam estas coroações são também enriquecidos pela presença de três personagens inéditos: os chamados cavaleiros, que seguem à frente do cortejo, imediatamente a seguir à bandeira do Espírito Santo. Geralmente escolhidos entre rapazes ou adolescentes, estes personagens envergam uma toalha branca caída sobre o peito e enfeitada por cinco laços vermelhos e cor-de-rosa. Dois deles transportam consigo uma vara florida, enquanto o do meio conduz o guião do Espírito Santo, utilizado exclusivamente no quadro dos Gastos.

$\mathrm{Na}$ vertente alimentar, por seu turno, os festejos requerem a preparação de um conjunto tradicionalmente definido de alimentos cerimoniais, entre os quais avultam as Sopas do Espírito Santo - feitas também à base de carne de rês cozida e de pão de trigo, mas diferindo em inúmeros aspectos 
de detalhe do tipo de Sopas usadas em Santa Bárbara ${ }^{1}$ - um certo número de variedades de biscoitos e massa sovada - entre as quais avultam o pão de leite, a massa da noite, a massa de São Miguel, rosquilhas fervidas e rosquilhas de aguardente - e ainda duas variedades principais de pão de trigo - pão de esmola e pão de cabeça ${ }^{2}$. Estes alimentos são preparados em quantidades muito significativas e requerem um elevado dispêndio de dinheiro ou géneros, suportado em parte importante - cerca de $60 \%$ pelo mordomo. Os restantes $40 \%$ provêm, por um lado, da contribuição dos membros da irmandade. Cada um deve entregar ao mordomo uma determinada soma em dinheiro e uma certa quantidade de ovos — utilizados na confecção da massa sovada - variável de irmandade para irmandade. Por outro lado, cada mordomo recebe ainda algumas dezenas de ofertas em géneros de parentes e vizinhos. E sobre o mordomo que recaem também as responsabilidades de confecção dos alimentos. Para o efeito, ele apoia-se num gupo de ajudantes femininas, as amassadeiras, que são dirigidas por uma mestra. Estas têm a seu cargo a preparação do conjunto dos alimentos necessários aos festejos, com excepção do abate e da preparação prévia das reses, cuja responsabilidade recai sobre um grupo de ajudantes masculinos, à frente dos quais se encontra o marchante.

Os alimentos circulam no quadro dos festejos sob a forma de um conjunto de refeições, ofertas e distribuições tradicionalmente regulamentadas. A mais importante dessas prestações é constituída por uma grande refeição que tem lugar, em cada um dos domingos, a seguir à coroação, na Casa do Espirito Santo. Essa refeição - conhecida tanto nos Jantares como nos Gastos pela designação genérica de Jantar - consta de Sopas do Espírito Santo, massa sovada e vinho e nela participam algumas centenas de pessoas, entre as quais a totalidade dos membros da irmandade respectiva e um conjunto amplo de convidados do mordomo. Os irmãos e ajudantes emigrados fazem-se

${ }^{1}$ As Sopas do Espirito Santo em Santo Antão são temperadas com sal, pimenta, nabo, couve, cebola, alho, etc... Já depois de cozidas e antes de serem servidas é-lhes acrescentado molho de carne de rês assada, pedaços de fígado de vaca, linguiça e salsa.

${ }^{2} \mathrm{O}$ pão de leite requer, para cada fornada - cerca de 17/18 pães, $15 \mathrm{~kg}$ de farinha, 5 dúzias de ovos, $750 \mathrm{~g}$ de manteiga, 2 colheres de banha, $3 \mathrm{~kg}$ de açúcar, fermento e 1 litro de água misturada com leite. A massa de São Miguel, por seu turno, requer, para cada fornada cerca de $12 / 13$ pães, $10 \mathrm{~kg}$ de farinha, 5 dúzias de ovos, $3 \mathrm{~K} \mathrm{~kg}$ de açúcar, $1 \mathrm{~kg}$ e $250 \mathrm{~g}$ de manteiga, fermento e lima. A massa da noite é similar à de São Miguel, só que requer mais ovos. Quanto às rosquilhas fervidas, para cadafornada - cerca de 120 rosquilhas - são necessários $7 \mathrm{~kg}$ de farinha, 4 dúzias de ovos, $1 \mathrm{~kg}$ de açúcar, ${ }^{\prime} A$ litro de álcool puro, 2 colheres de fermento e $250 \mathrm{~g}$ de manteiga. Antes de serem levados ao forno, as rosquilhas são fervidas em água. A massa a partir da qual são feitas as rosquilhas de aguardente é similar à utilizada na confecção das rosquilhas fervidas, só que mais mole e sem prévia cozedura em água. Quanto aos pães de esmola e aos pães de cabeça, a sua massa é idêntica à do vulgar pão de água só que ligeiramente temperada - e é sobretudo no sua forma exterior que estes dois tipos de pão se distinguem. 
geralmente representar - tanto nesta refeição, como no conjunto de outras sequências em que é requerida a sua presença - através de uma casa da freguesia por eles indicada. Entre os convidados para o Jantar, é usual cada mordomo incluir doze pobres. Tradicionalmente, participava também no Jantar a folia que, através de quadras apropriadas, introduzia os diferentes pratos, dirigia saudações ao mordomo e aos restantes convivas, etc... Desde que esta foi substituída pela filarmónica, os seus componentes são também convidados para o Jantar devendo executar, no seu termo, alguns números musicais em honra do mordomo. Em articulação com esta refeição e antes do seu início, realiza-se uma distribuição de esmolas, previamente benzidas pelo padre, por cerca de duas a três dezenas de casas mais pobres, escolhidas por cada um dos mordomos. Estas esmolas constam de um pão de trigo - o chamado pão de esmola - e, eventualmente, de uma porção de carne de rês crua. Na ocasião é também oferecido um copo de vinho a cada uma das pessoas que recebe a esmola. No termo da refeição, tem por seu turno lugar a distribuição de um pão de trigo - o chamado pão de cabeça - exclusivamente destinada aos membros da irmandade. Estes são ainda abrangidos por uma pequena refeição - conhecida pela designação genérica de almoço - à base de massa sovada e vinho que se realiza na Casa do Espírito Santo previamente à coroação. A par destas prestações mais importantes, a sequência ritual de Jantares e Gastos prevê ainda outras formas de circulação do alimento. Assim, na madrugada de domingo, realiza-se uma distribuição porta-a-porta de Sopas do Espirito Santo que pode abranger, nos casos mais expressivos, perto de duas a três dezenas de casas, escolhidas por cada um dos mordomos de acordo com critérios variáveis. Uma vez terminados os festejos, tem também lugar uma distribuição porta-a-porta de presentes em massa sovada, que, entre outros objectivos, visa retribuir as ofertas em géneros feitas ao mordomo pelas casas que não fazem parte da irmandade. Integram ainda a sequência dos festejos um certo número de dádivas alimentares em carne de rês crua, distribuídas entre as amassadeiras, e um brinde - com massa sovada e vinho - feita aos membros da filarmónica na véspera do início dos festejos.

Este conjunto de prestações é comum a Jantares e Gastos. Nestes últimos, porém, elas caracterizam-se por uma maior amplitude. Assim, no Gasto de Pentecostes, realizam-se não uma mas várias refeições - uma por cada dia por que se prolongam os festejos - que abrangem no seu conjunto perto de mil pessoas. No Gasto da Trindade, apesar de, à semelhança dos Jantares, se realizar uma só refeição, o número de participantes é em geral mais elevado que nestes: cerca de quatrocentos, contra duzentos/trezentos. Da mesma maneira, as esmolas distribuídas em ambos os Gastos são geralmente em número superior às distribuídas no quadro dos Jantares. A par desta maior amplitude, algumas das prestações que integram os Gastos possuem ainda um conteúdo distinto. E o caso das esmolas, que além do pão de esmola, envolvem obrigatoriamente a distribuição de carne de rês crua. E é também o caso da oferenda alimentar feita aos membros da irmandade que, em vez de um 
pão de cabeça, é integrada por um prato de doces - o chamado serviço da coroa - de confecção mais trabalhosa e dispendiosa e cuja distribuição é assegurada pelos cavaleiros. Entre esses doces - aos quais fizemos alusão no capítulo anterior - merecem particular relevo as espécies, as rosquilhas brancas, os esquecidos, os caramelos, os suspiros e o pão level.

Proporcionalmente a este conjunto de acrescentamentos e enriquecimentos, os Gastos requerem uma despesa superior à dos Jantares. Enquanto que nestes últimos, ela se situa em média por volta dos 200/400 contos, no Gasto da Trindade ela eleva-se a 600 contos podendo atingir no Gasto de Pentecostes valores superiores a 1.000 contos. Esta despesa monetária corresponde, nos Jantares, aos seguintes gastos médios em géneros: uma cabeça de gado, entre 10 a 15 sacas de farinha $(500$ a $750 \mathrm{~kg}), 1$ saca de açúcar $(50 \mathrm{~kg}), 20$ a $25 \mathrm{~kg}$ de manteiga, 70 a 80 dúzias de ovos, 2 quintos de vinho, etc... O Gasto de Pentecostes requer, pelo seu lado, três a quatro reses e quantidades significativamente mais elevadas dos restantes géneros. No Gasto da Trindade, por fim, são usualmente necessárias duas reses. A contribuição dos membros da irmandade para os festejos apresenta também nos Gastos um valor mais elevado. Enquanto que nos Jantares ela é em geral de mil escudos e uma dúzia de ovos, os irmãos do Gasto de Pentecostes oferecem ao mordomo respectivo $3.000 \$ 00$ e três dúzias de ovos e os do Gasto da Trindade $2.000 \$ 00$ e duas dúzias de ovos².

Simultaneamente aos Gastos têm lugar as Festas. Estas atingem o seu ponto culminante num conjunto de distribuições de bolos e no bodo de leite. Estas duas distribuições possuem uma relativa autonomia em relação às prestações alimentares que temos vindo a referir e apoiam-se também em critérios distintos dos que até agora encontrámos. Na sua base, em vez do dispêndio cerimonial do mordomo e da irmandade, encontra-se um conjunto de

\footnotetext{
${ }^{1}$ As espécies são um biscoito em forma de ferrradura pequena, com um revestimento exterior de massa e um creme levemente doce e picante no interior. A massa exterior é confeccionada a partir de $1 \mathrm{~kg}$ de farinha, $125 \mathrm{~g}$ de manteiga, entre 5 a 6 claras de ovo, sal e fermento. A parte é preparado o creme em cuja composição entram ${ }^{\mathrm{X}} \mathrm{A}$ litro de água, $1 \mathrm{~kg}$ de açúcar, 125 g de manteiga e pão torrado; depois do creme levantar fervura são-lhe acrescentados os seguintes temperos: raspa de limão, noz moscada, canela moída, cacau, erva doce e pimenta. Cada fornada de espécies comporta entre 12 a 15 espécies. Quanto às rosquilhas brancas, cada fornada requer $4 \mathrm{~kg}$ de farinha, Vi $\mathrm{kg}$ de açúcar, dúzia de ovos e 20 colheres de banha ou manteiga; no fim da cozedura, as rosquilhas são revestidas de açúcar em ponto. Cada fornada de esquecidos - cerca de 60/ 80 esquecidos - requer $1 \mathrm{~kg}$ de farinha, 16 ovos, 8 claras de ovos, $1 \mathrm{~kg}$ de açúcar e limão. Quanto às receitas dos suspiros, caramelos e do pão leve, não são muito diferentes das usualmente utilizadas para esse tipo de doces. Cada serviço de coroa comporta em cada um dos Gastos - Pentecostes e Trindade - respectivamente três e quatro exemplares dos diferentes tipos de doces.

${ }^{2} \mathrm{O}$ conjunto de números e cálculos acima apresentado toma como ano de referência 1988.
} 
contribuições de casas da freguesia que se associam de forma autónoma aos festejos. Os critérios que presidem à própria distribuição do alimento são também distintos: a sua circulação, em vez de privilegiar conjuntos limitados de indivíduos e casas, é geral e aberta.

As distribuições de bolos, que são previamente benzidos pelo padre, intervêm tanto no Gasto de Pentecostes - na 2. ${ }^{\mathrm{a}}$ e na 3. ${ }^{\mathrm{a}}$ feira - como no Gasto da Trindade - no domingo respectivo - e decorrem junto à Casa do Espírito Santo. Diferentemente do que se passa na maioria das ilhas do grupo central, a entrega destes alimentos na Casa do Espírito Santo é feita de forma informal, não originando a organização de qualquer cortejo específico. No Gasto de Pentecostes, além dos bolos propriamente ditos - conhecidos também pela designação de vésperas - são ainda distribuídos coscorões - feitos à base de massa de trigo temperada e fritos em banha de porco. No Gasto da Trindade a distribuição consta unicamente de bolos, os chamados bolos mancebos l. A frente destas distribuições encontra-se a mesa da Irmandade do Divino Espírito Santo - uma irmandade própria, absolutamente distinta das irmandades ligadas aos Jantares e aos Gastos - que, além de centralizar os alimentos tomando nota num rol próprio das casas que realizaram ofertas e do quantitativo destas - está também encarregue de proceder à sua distribuição.

Quanto ao bodo de leite, ele é específico do Gasto de Pentecostes. Realizase na $2{ }^{a}$ feira de Pentecostes e consiste numa distribuição de leite acabado de ordenhar. A sua realização é antecedida por um cortejo, onde além das vacas cujo leite será distribuído no decurso do bodo, se integram a Rainha da Festa e as suas duas damas de honor - três adolescentes vestidas de branco e encarregues do transporte das Coroas - vários carros alegóricos com motivos variáveis de ano para ano - e ainda as duas filarmónicas existentes na freguesia. A chegada do cortejo ao Império, o padre procede à benção do gado e inicia-se então a distribuição do leite, ordenhado na altura. Simultaneamente realiza-se uma distribuição generalizada de fatias de pão de leite e de vinho.

A introdução do bodo de leite na estrutura dos festejos remonta aos anos 40 e é indissociável de dois factores principais: a existência de relações muito fortes entre a ponta SE de São Jorge e a ilha Terceira, donde os bodos são originários; a reorientação, a partir dos anos 40/50 da economia da freguesia no sentido da criação de gado como actividade dominante, em detrimento da complementariedade até então existente entre a criação de gado e a activi-

\footnotetext{
${ }^{1}$ As vésperas têm a forma exterior de um bolo redondo e achatado. Cadafornada de vésperas - correspondente a 25 vésperas - requer $9 \mathrm{~kg}$ de farinha, 2 dúzias de ovos, 2 litros de leite, $125 \mathrm{~g}$ de manteiga e $1 \mathrm{~kg}$ de açúcar. Quanto aos coscorões a sua massa é confeccionada com $4 / 5 \mathrm{~kg}$ de farinha e 3 dúzias de ovos - deixando algumas gemas de lado; depois de tendidos e dobrados, os coscorões são fritos em gordura de porco. Quanto aos bolos mancebos, embora o seu formato seja maior do que o das vésperas, a sua massa é idêntica.
} 


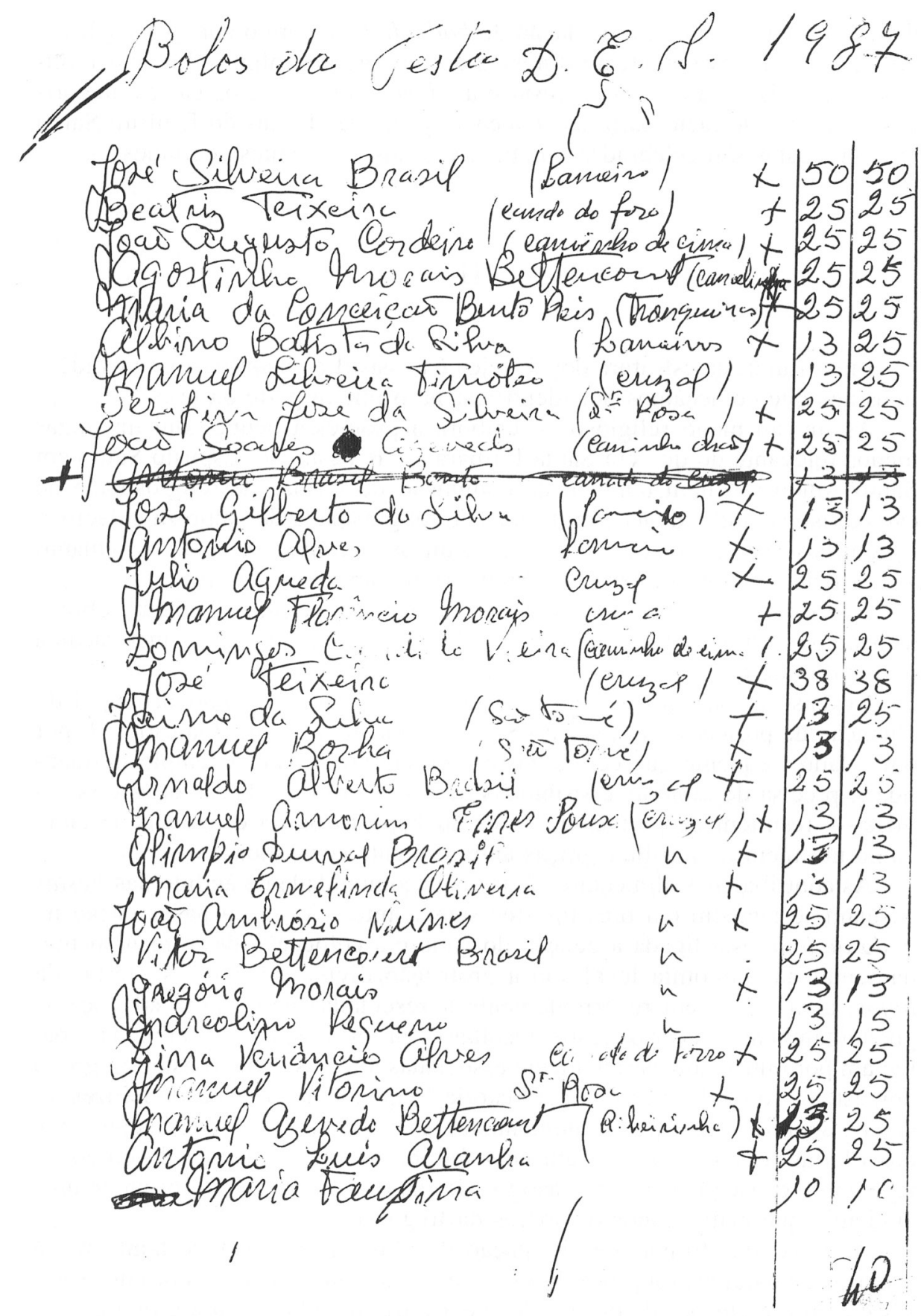

Extracto de um rol dos bolos da Festa (Santo Antão, 1987) 
dade agrícola. Quanto à articulação do bodo de leite com o cortejo alegórico, ela deve-se provavelmente à influência dos emigrantes: alguns dos seus motivos principais - a rainha da festa e as damas de honor, os carros alegóricos - fazem de facto parte da sequência ritual das Festas do Espírito Santo tal como estas são celebradas nos E.U.A. pelos emigrantes açorianos.

\section{III}

Em torno desta estrutura dos festejos é possível reencontrar motivos idênticos aos que começámos por identificar na primeira parte da tese.

Assim, no plano religioso - embora a promessa ocupe aqui um lugar menos relevante do que em Santa Bárbara - as Festas do Espírito Santo em Santo Aittão resultam também da conjunção de formas de religiosidade de características individuais com formas de religiosidade de natureza colectiva. E com base nas primeiras que se realizam os Jantares e os Gastos. Quanto às segundas, elas exprimem-se sobretudo no âmbito das Festas.

Tanto no plano individual como no plano colectivo, é também sobre o dispêndio de alimentos requeridos pelos festejos que repousa em grande medida o vínculo que eles estabelecem com a divindade.

No caso do mordomo, este dispêndio opera como o meio principal de obtenção da protecção do Espírito Santo para a sua unidade doméstica. E por outro lado frequente que certos gastos cerimoniais - por exemplo, a quantidade precisa de esmolas distribuídas ou o número de cabeças de gado abatidas - resultem de promessas feitas ao Espírito Santo e operem portanto como um meio de retribuir graças anteriormente concedidas.

As contribuições alimentares feitas pela comunidade no âmbito das Festas baseiam-se também em pressupostos semelhantes. Assim, a participação no bodo de leite está ligada à benção do gado e à colocação deste recurso fundamental da economia local sob a protecção divina. Quanto às ofertas de bolos, além de serem recorrentemente apresentadas como uma «devoção», podem também, em certos casos, resultar de promessas. No passado, elas apareciam por outro lado estreitamente associadas a ideias de bem-estar do grupo doméstico, como decorre de uma história frequentemente evocada na freguesia, de acordo com a qual o momentâneo abandono, no decurso dos anos 40 , das ofertas de coscoroes - em cuja feitura intervem a banha de porco teve como consequência um «castigo» do Espírito Santo, sob a forma de uma epidemia que matou todos os porcos da freguesia.

Algumas das formas de circulação do alimento baseiam-se também em critérios de natureza religiosa. E o que se passa com as distribuições de esmolas e com a inclusões de doze pobres entre os convidados para a refeição na Casa do Espírito Santo. 
Simultaneamente, o conjunto de refeições, dádivas e distribuições alimentares que passámos em revista possui uma importante dimensão sociológica.

Esta dimensão sociológica começa também por operar num âmbito restrito, como um instrumento de reafirmação dos laços sociais existente entre cada um dos mordomos e o conjunto de indivíduos e grupos domésticos que fazem parte do seu círculo de relações: parentes, vizinhos, amigos, etc..

$\mathrm{O}$ vínculo entre estas esferas sociais e os festejos é particularmente importante no referente ao parentesco e começa por assentar nos critérios que presidem à formação do grupo de amassadeiras encarregue da preparação culinária dos festejos. Como decorre do quadro 25, um número importante dessas ajudantes é de facto recrutada entre parentes do mordomo e da mordoma. Quanto aos ajudantes masculinos que asseguram o abate e a preparação prévias das reses, todos eles são - com excepção do marchante - - parentes dos mordomos.

Simultaneamente um número importante das ofertas em géneros recebidas por cada mordomo como contributo para as despesas envolvidas nos festejos é também feita por parentes (cf. quadro 26).

Paralelamente ao parentesco, a vizinhança desempenha também - embora de uma forma menos constrangente do que em Santa Bárbara, provavelmente devido à inexistência da categoria formal dos vizinhos de perto - um papel importante. Assim, em dois dos Jantares atrás referidos - o $2 .^{\circ}$ e $05^{\circ}-$ algumas das amassadeiras — respectivamente duas e cinco — foram recrutadas com base nesse critério. E do total de ofertas em géneros feitas a cada um dos mordomos, entre três a cinco foram também feitas por unidades domésticas da sua vizinhança mais próxima.

E também nestas esferas sociais que o alimento apresenta formas mais densas de circulação. Como vimos, as amassadeiras recebem em sua casa

\begin{tabular}{lcc}
\hline & a m a s a d e iras & par e n te s \\
\hline 1 Jantar & 13 & 6 \\
2. Jantar & 9 & 3 \\
3. Jantar & 14 & 8 \\
4. Jantar & 12 & 6 \\
5. Jantar & 8 & 3 \\
6. Jantar & 10 & 8 \\
Gasto Pentecostes & 19 & 13 \\
Gasto Trindade & 17 & 3 \\
\hline
\end{tabular}




\begin{tabular}{lcc}
\hline & OFERTAS & PARENTES \\
\hline $1 . \circ$ Jantar & 37 & 8 \\
2. Jantar & 20 & 10 \\
3. Jantar & 29 & 11 \\
$4 . \circ$ Jantar & 26 & 16 \\
$5 . \circ$ Jantar & - & - \\
6. Jantar & 44 & 15 \\
Gasto Pentecostes & 31 & 21 \\
Gasto Trindade & - & - \\
\hline
\end{tabular}

QUADRO 26

Parentes e ofertas nos Jantares e Gastos (Santo Antão, 1988)

uma prestação de carne crua. Em muitos casos elas são também abrangidas pela distribuição matinal de Sopas do Espírito Santo que tem lugar no domingo. Finalmente, é usual que, no termo dos festejos, elas recebam ainda um presente em massa sovada. Quanto às unidades domésticas que realizaram ofertas ao mordomo, elas são também abrangidas, como vimos, pela distribuição porta-a-porta de presentes em massa sovada.

Mas a prestação alimentar mais significativa deste ponto de vista é sem dúvida o jantar propriamente dito. Neste, além dos membros da irmandade respectiva participam ainda, como vimos, um grande número de convidados do mordomo. Os critérios para estes convites baseiam-se em pressupostos idênticos aos que temos vindo a passar em revista. Para além da vizinhança, é posto particular ênfase no parentesco. De facto, entre 20 a $50 \%$ das unidades domésticas convidadas fazem parte das relações de parentesco do mordomol. Uma das preocupações centrais deste é justamente a de que nenhum parente - mesmo afastado - deixe de ser convidado: uma qualquer omissão nessa área seria considerada como uma quebra grave do código de sociabilidade que rege as relações entre parentes. Daí que o jantar em si seja valorizado como uma ocasião privilegiada de reencontro e reunião da parentela.

A par destes círculos privilegiados de relacionamento social, os convites para o jantar estendem-se ainda a outro tipo de relações sociais. Entre estas, contam-se, em primeiro lugar, as que se baseiam no código mais informal da

\footnotetext{
${ }^{1}$ Os cálculos relativos ao peso dos parentes e vizinhos entre os convidados para o Jantar propriamente dito foram estabelecidos com base nos róis de visitas. De facto, de uma forma geral, as casas convidadas para o Jantar contam-se entre as que realizam previamente uma oferta ao mordomo.
} 
amizade. Em segundo lugar, é também frequente a extensão desses convites - particularmente nos Gastos - para unidades domésticas, muitas vezes residentes fora da freguesia, a quem o mordomo está devendo favores ou com as quais mantém relações regulares de troca de serviços.

É também de acordo com pressupostos similares que podem ser analisados alguns dos critérios que presidem à organização dos cortejos que rodeiam a coroação. De facto, o conjunto de personagens que integram a secção central do cortejo - os rapazes ou raparigas que transportam os ramos, as crianças ou adolescentes que são coroados, os adultos que asseguram o transporte das Coroas para a igreja, e, nos Gastos, os três cavaleiros - são fundamentalmente escolhidos entre as unidades domésticas aparentadas aos mordomos. Paralelamente, ocorrem também, sobretudo em relação às crianças e adolescentes coroados, casos de escolha de vizinhos. Por fim, é usual que cada mordomo se faça acompanhar no cortejo de alguns parentes mais chegados e distribua entre os restantes, assim como entre vizinhos e amigos que quer honrar, algumas das varas reservadas aos membros da irmandade.

A ligação dos Jantares e dos Gastos à reiteração das relações sociais próximas do mordomo assume um significado acrescido quando este é um emigrante. Foi o que se passou, em 1988, com o $1 .^{\circ}$ e o $5 .^{\circ}$ Jantares e corrf ambos os Gastos. Tal como em Santa Bárbara, os festejos fornecem então uma ocasião particularmente importante de momentâneo reagrupamento de indivíduos e famílias separados pela emigração, eventualmente aproveitado também para a celebração de outros ritos familiares. Foi o que sucedeu, nesse mesmo ano, com o Gasto da Trindade, a cuja realização se seguiu, uma semana mais tarde, o casamento de uma das filhas do mordomo.

Começando por privilegiar os círculos sociais próximos de cada mordomo, a circulação do alimento no quadro das Festas do Espírito Santo em Santo Antão possui também uma dimensão mais ampla e decisiva, relacionada mais uma vez com as duas instâncias centrais sobre as quais assenta o sistema social local: o lugar - ou arrabalde - e a freguesia.

A freguesia constitui o quadro fundamental da organização social. Dois factos expressam com particular nitidez essa sua característica: uma elevada taxa de endogamia - que se situa perto dos $\mathrm{SO}^{\wedge} o^{1}-$ e uma forte consciência de si própria, com múltiplas expressões em verbalizações e práticas de natureza «sociocêntrica».

Quanto ao lugar, além de constituir a unidade base do povoamento da freguesia, configura também em muitos casos uma importante unidade social

\footnotetext{
${ }^{1}$ Estes números foram calculados a partir do recenseamento das casas da freguesia que elaborei no decurso da pesquisa de terreno.
} 


\begin{tabular}{|c|c|}
\hline JANTAR & LUGAR \\
\hline 1. ${ }^{\circ}$ Jantar & São Tomé \\
\hline 2. ${ }^{\circ}$ Jantar & Com. Chão \\
\hline $3 .^{\circ}$ Jantar & São Tomé \\
\hline 4. ${ }^{\circ}$ Jantar & Santa Rosa \\
\hline 5. Jantar & Cruzal \\
\hline
\end{tabular}

intermédia. E o que sucede com aqueles que vimos serem os lugares mais importantes da freguesia: São Tomé, Cruzai, Santa Rosa e Caminho Chão. Dispondo de um conjunto de equipamentos próprios - comércio, escolas, ermidas - que reforçam a sua autonomia, estes lugares desenham ainda um quadro preferencial de relacionamento social. Nalguns casos, a sua personalidade reflecte-se mesmo no afloramento de uma consciência "sociocêntrica» embrionária e ainda numa certa endogamia de lugar. E o que se passa em particular em São Tomé e no Cruzai, onde justamente a tendência endogâmica é mais acentuada: $41 \%$ em São Tomé e $45 \%$ no Cruzai.

Tal como em Santa Bárbara, é justamente como um instrumento de reiteração dos laços existentes no âmbito destas duas unidades sociais e da reafirmação da sua identidade que a circulação cerimonial do alimento no quadro das Festas do Espírito Santo assume maior relevância.

O vínculo entre os festejos e o lugar estabelece-se por intermédio da série inicial de Jantares, e assenta sobretudo nas respectivas irmandades. Estas, como vimos, além de procederem à nomeação anual do mordomo, têm um relevante papel no decurso dos festejos, e, em particular, na sua vertente alimentar. Além de suportarem uma parte do dispêndio cerimonial requerido pelo Jantar, os seus membros constituem uma das esferas onde a circulação do alimento é mais intensa. Além do almoço e da oferenda alimentar que lhes é exclusivamente destinada, participam em plano de relevo na refeição que tem lugar na Casa do Espirito Santo - onde além de serem os primeiros a entrar, ocupam ainda a mesa central. Em caso de impossibilidade pontual de algum dos seus membros comparecer à refeição, por outro lado, o mordomo está obrigado a levá-la a sua casa.

Ora, em cinco desses seis Jantares, existe uma correspondência entre a pertença a uma determinada irmandade e a pertença a um dos lugares principais da freguesia: São Tomé, Cruzai, Santa Rosa e Caminho Chão (cf. quadro 27).

Essa correspondência é particularmente clara no $1 .^{\circ}$ e no $5 .^{\circ}$ Jantares, onde o número de membros das irmandades que pertencem a São Tomé, por um 
lado, e ao Cruzai, por outro, representam respectivamente $87 \%$ e $72 \%$ do total dos irmãos e ajudantes $l^{l}$.

Mas ela reencontra-se, embora de forma menos nítida, nos outros Jantares. Assim, no $2 .^{\circ}$ Jantar, $57 \%$ dos membros da respectiva irmandade pertencem ao Caminho Chão e no $3 .^{\circ}$ Jantar, $56 \%$ pertencem a São Tomé. No $4 .^{\circ}$ Jantar essa ligação é aparentemente mais frágil: embora o lugar que forneça mais irmãos e ajudantes seja o de Santa Rosa, estes não representam senão $27 \%$ do total de membros da irmandade. Se acrescentarmos entretanto a esses irmãos e ajudantes os provenientes de outros lugares menores situadas nas imediações de Santa Rosa, obtemos uma percentagem mais significativa: $50 \%$.

Este vínculo entre os Jantares e os principais lugares da freguesia reencontra-se ainda nos critérios que presidem à circulação do alimento fora do quadro da irmandade. Em cada um dos lugares que têm vindo a ser referidos existe um certo número de casas - entre 25 a $30 \%$ - que não integram a respectiva irmandade. Essas casas, na sua maioria, acabam entretanto por ser abrangidas pelas diferentes prestações alimentares. Algumas delas figuram entre os convidados do mordomo à refeição que tem lugar na Casa do Espírito Santo e contam-se também entre aquelas que lhe fizeram ofertas alimentares prévias; no termo dos festejos recebem portanto em suas casas um presente em massa sovada. Outras, particularmente as de menores recursos económicos, são alvo das atenções do mordomo, no quadro da distribuição de esmolas e ainda no âmbito da distribuição porta-a-porta de Sopas do Espírito Santo.

Tanto o vínculo preferencial entre lugares e irmandades como estes dispositivos emprestam aos Jantares características de uma celebração que, por intermédio da linguagem da dádiva alimentar, reafirma os laços sociais entre habitantes de um mesmo lugar e sublinha a sua identidade no quadro da freguesia.

Este vínculo entre irmandades e lugares, que se apresenta já de uma forma diluída no $6 .^{\circ}$ Jantar, enfraquece-se decisivamente nos Gastos. Proporcionalmente ao maior dispêndio requerido pelos festejos, os critérios de pertença a estas duas irmandades deixam de ser de tipo «horizontal» - a pertença a um mesmo lugar - para passarem a reflectir preferencialmente critérios de tipo «vertical» - o estatuto sócio-económico mais elevado dos seus membros. Muitas pessoas na freguesia definem de facto os Gastos como «os Jantares dos ricos». Este vínculo entre os Gastos e a elite socio-económica local é particularmente clara no Gasto de Pentecostes: da sua irmandade fazem parte, entre outros, alguns dos mais abastados criadores de gado da freguesia, os principais comerciantes locais, o presidente da Cooperativa - ex-presidente da Junta de Freguesia - assim como outras figuras de relevo na «pequena política» local. Os emigrantes mais bem sucedidos da freguesia distribuem-se também por esta irmandade e ainda pela irmandade do Gasto da Trindade. A circulação do alimento recebe em consequência um significado sociológico

${ }^{1}$ Estes cálculos — bem como os seguintes - não levam em conta os emigrantes. 
distinto, de afirmação dos laços de pertença a um grupo de «status» particular e a equação entre Festas do Espirito Santo e prestigio individual - mais diluída nos Jantares - apresenta-se aqui de forma mais nítida. Não é aliás por caso que, em ambos os Gastos, a indicação do mordomo do ano seguinte é frequentemente alvo de discussões acaloradas, em resultado das pressões exercidas pelas estratégias de prestígio individual sobre a regra da rotatividade no acesso ao cargo de mordomo.

Isso não significa entretanto o abandono do tipo de trabalho sociológico inaugurado pela série inicial de Jantares. Promovidos de acordo com motivações onde o prestígio individual é relevante, os Gastos acabam por fornecer o contexto ritual para um discurso em que a comunidade acaba por surgir como o sujeito mais em evidência. De facto, simultaneamente aos Gastos, têm lugar as Festas, cujo núcleo central é constituído, como vimos, por um conjunto de prestações alimentares - distribuições de bolos e bodo de leite - autónomas das refeições e distribuições asseguradas pelo mordomo e pela irmandade. Através dessas prestações é justamente à continuação desse trabalho sociológico que podemos assistir. Depois de se ter colocado ao serviço da reafirmação da identidade do lugar, a circulação do alimento passa então a estar ao serviço da reiteração dos laços sociais no âmbito da freguesia e da reafirmação da sua identidade enquanto corpo social unificado.

$\mathrm{O}$ vínculo entre essas prestações e a freguesia decorre em primeiro lugar da intervenção decisiva que os seus habitantes têm no seu financiamento e organização. Esta intervenção assume formas particularmente importantes no quadro do bodo de leite. A distribuição de leite propriamente dita conta de facto com a participação da maior parte dos pastores da freguesia. A distribuição de pão de leite e vinho que a acompanha assenta também em mecanismos comunitários. A sua organização está a cargo de uma comissão de dez a doze casas nomeada anualmente e à qual, rotativamente, todas as casas da freguesia devem pertencer. Os alimentos distribuídos resultam pelo seu lado de um peditório que, algum tempo antes dos festejos, percorre o conjunto da freguesia. Quanto às distribuições de bolos - apesar da concorrência do bodo de leite -, elas continuam a envolver também uma participação significativa das casas da freguesia: cerca de noventa a cem casas - correspondentes a $40 \%$ do total da freguesia - associam-se regularmente a elas, mediante ofertas de quantidades tradicionalmente definidas de alimentos, as chamadas contas ou meias contas. Na Festa de Pentecostes cada conta corresponde a vinte e cinco bolos e vinte e cinco coscorões e cada meia conta a treze bolos e treze coscorões. No Festa da Trindade, cada conta corresponde a quinze bolos mancebos.

$\mathrm{O}$ vínculo que se estabelece entre as distribuições de bolos e o bodo de leite e a freguesia reencontra-se, em segundo lugar, nos critérios que presidem à distribuição destas prestações alimentares. Como verificámos antes, diferentemente das restantes prestações - que se destinam a conjuntos determinados de indivíduos ou grupos domésticos - , as distribuições de bolos e 
o bodo de leite possuem como característica distintiva uma circulação ilimitada e generalizada. Por detrás desta amplitude na circulação do alimento é de novo o horizonte sociológico da freguesia que emerge.

Esta desenha por um lado o quadro preferencial de circulação dos alimentos. Tanto as distribuições de bolos, como o bodo de leite começam por reunir em seu torno um grande número de vizinhos e é entre eles que os alimentos distribuídos são primeiro que tudo consumidos e partilhados. Se os Jantares se configuravam como uma refeição colectiva formal privilegiadamente centrada sobre o conjunto dos habitantes de um dado lugar, a articulação das Festas com estas distribuições alimentares empresta a estas, por seu turno, características de uma refeição informal alargada ao conjunto da freguesia.

A amplitude que caracteriza a circulação do alimento estende-se em segundo lugar às pessoas de fora da freguesia que, acorrendo em grande número aos festejos, são convidadas a associar-se às distribuições alimentares em curso. Esta faceta dos festejos é particularmente forte na Festa de Pentecostes, em particular no decurso da 2. ${ }^{a}$ feira de Pentecostes. Nesse dia, além do bodo de leite, realiza-se ainda uma distribuição de bolos especialmente destinada aos forasteiros.

Por detrás desta hospitalidade alimentar é de novo a freguesia que se perfila. Tal como em Santa Bárbara, o alimento funciona aqui como um instrumento através do qual a freguesia, abrindo-se para o exterior, pode afirmar de forma plena a sua identidade e reivindicar um prestígio acrescido. Este vínculo entre o alimento e o prestígio colectivo da freguesia é particularmente marcado no bodo de leite. Os pastores escolhem para o efeito as melhores vacas que, não tendo sido propositadamente ordenhadas de manhã, se apresentam no bodo com os úberes literalmente a abarrotar de leite, numa óbvia demonstração de abundância. Os temas predominantes de conversa incidem justamente sobre as qualidades do gado presente, ou sobre a excelência do seu leite. As distribuições de bolos possuem uma dimensão idêntica: a abundância e a liberalidade com que são distribuídos, a própria qualidade da massa e a apresentação estética dos alimentos - baseada em motivos \{pombas do Espirito Santo, coroas e flores estilizadas, etc...) impressos na massa por meio de pequenos chavões de madeira - são particularmente valorizadas.

Esta orientação dos festejos, embora asssente sobretudo nas distribuições alimentares que temos vindo a analisar, afecta também o carácter das prestações alimentares asseguradas no âmbito de cada um dos Gastos pelos respectivos mordomos. Não só o número de indivíduos e casas abrangido pelas refeições na Casa do Espirito Santo e pelas esmolas é, comparativamente aos Jantares, maior, como, sobretudo no Gasto de Pentecostes, certos aspectos da circulação do alimento acabam por ser «contaminados» pelos critérios seguidos nas distribuições de bolos e no bodo de leite. E o que se passa com a refeição que tem lugar na 2. ${ }^{a}$ feira de Pentecostes. Coincidindo com o dia em que é máxima a abertura dos festejos para o exterior, ela não só é reservada a convidados de fora da freguesia, como é também frequente que a estes se juntem outros foras- 
teiros que, embora não convidados, solicitam ao mordomo licença para participarem na refeição. Em nome da hospitalidade alimentar em relação ao exterior que é característica desse dia, esses pedidos são geralmente satisfeitos.

Esta espécie de «contaminação» dos Gastos pelos critérios sociológicos que presidem à circulação do alimento nas Festas deve ser sublinhada. Por seu intermédio, a comunidade, ao mesmo tempo que aceita a lógica individualista inscrita nos desempenhos dos mordomos respectivos, tenta de alguma maneira ligá-los à afirmação da identidade e do prestígio colectivo da freguesia. «Individualismo» e «holismo» deixam-se mais uma vez ver, não como propriedades mutuamente exclusivas, mas como registos de alguma forma sobreponíveis.

\section{IV}

A vinculação das Festas a ideias de reafirmação dos laços sociais no âmbito da freguesia e de reiteração periódica da sua identidade como corpo social unificado reflecte-se noutras facetas dos festejos.

E o que se passa em primeiro lugar com alguns aspectos relacionados com a participação que têm neles as duas filarmónicas existentes na freguesia: a «Recreio dos Lavradores», também conhecida por música velha e cuja fundação remonta a finais do século passado e a «Nova Aliança», ou música nova, criada em 1965. Estas duas filarmónicas mantêm entre si uma forte rivalidade cujas raízes remontam aos anos 40/50. Nessa ocasião formaram-se na freguesia dois partidos rivais, um ligado à figura do padre, outro ligado à figura do médico local, que exercia também funções de direcção na Cooperativa agrícola. Esses partidos mantinham entre si relações de hostilidade aberta: houve famílias que deixaram de se falar, processos em tribunal, algumas das casas mais ligadas ao partido do médico deixaram de frequentar a igreja e muitas das casas ligadas ao partido do padre abandonaram a cooperativa. Foi justamente no quadro desta situação - que pode ser analisada à luz de alguns dos pressupostos desenvolvidos por Boissevain em «Saints and Fireworks» (1965) e posteriormente aprofundados em «Friends of Friends» (1978: 206 a 226) a propósito das rivalidades entre partiti numa freguesia rural da ilha de Malta - que se deu a criação da música nova: alguns dos músicos da «Recreio dos Lavradores» cuja direcção alinhava preferencialmente com o partido do padre — decidiram a criação de uma nova filarmónica, identificada com a figura do médico. Esta foi inicialmente boicotada pelo partido do padre - que lhe moveu um processo em tribunal - e só em 1971 pôde realizar a sua primeira exibição pública. Embora hoje em dia esta divisão da freguesia em dois partidos rivais se tenha atenuado, as duas músicas continuam a manter entre si um forte antagonismo, avaliado localmente de forma contraditória. Para uns, trata-se de um facto nega- 
tivo: «quando se formam numa freguesia dois partidos rivais, nunca mais há concerto e vêem-se muitas coisas tristes». Para outros, porém, a existência de duas filarmónicas rivais é encarada de fornia positiva. É dado o exemplo de uma freguesia vizinha - Ribeira Seca - onde o desaparecimento de uma de duas filarmónicas também rivais conduziu, anos depois, à extinção da outra e a emulação é vista como um factor de progresso: «quando não há guerra, não há comércio, está tudo morto». As expressões dessa rivalidade são múltiplas e vários incidentes têm marcado, em anos recentes, o relacionamento entre as duas músicas. Devido a esse facto, as duas filarmónicas recusam-se, salvo em raras ocasiões, a tocar em conjunto e os mordomos vêem-se obrigados a convidar para os festejos uma delas, com exclusão da outra. A Festa de Pentecostes articula-se justamente com uma das poucas excepções a esta norma. No quadro das sequências mais directamente relacionadas com o bodo de leite, as duas filarmónicas, pondo momentaneamente de parte as suas rivalidades, tocam em conjunto. Como vimos, o bodo de leite representa, no âmbito mais geral dos festejos, um dos pontos altos da afirmação da unidade da freguesia. Não deixa de ser significativo que seja justamente essa a ocasião onde, em nome dessa unidade, é encenada uma momentânea supressão dos factores de divisão internos à freguesia que as rivalidades entre as duas filarmónicas expressam.

E também de acordo com pressupostos similares que pode ser examinada a instituição das chamadas casas de ver a festa. Esta instituição - que entrou em declínio no seguimento do sismo de 1981 - designa um conjunto de casas, situadas na proximidade imediata da Casa do Espírito Santo e do Império, que eram utilizadas exclusivamente na altura das Festas de Pentecostes e da Trindade, encontrando-se desocupadas durante o resto do ano. Constituindo propriedade conjunta de várias famílias, residentes habitualmente em lugares menos centrais, essas casas eram tradicionalmente utilizadas para acomodar essas famílias ao longo de todo o período de duração das Festas. Facilitando a concentração da população no "coração» geográfico dos festejos, elas deixavam-se ver como uma transcrição para o plano espacial, das ideias de unificação da freguesia inscritas nos Festas.

Finalmente, é ainda na perspectiva dos vínculos estreitos existentes entre as Festas do Espírito Santo e a afirmação da identidade da freguesia que é possível examinar o papel que estas desempenharam no processo que, no decurso do século passado, conduziu à criação da freguesia de Santo Antão.

A existência de Santo Antão enquanto freguesia e paróquia autónoma remonta de facto a 1889. Até então, Santo Antão constituía apenas um curato da paróquia e freguesia do Topo. O processo que rodeou a sua autonomização foi um processo longo e marcado por incidentes vários que opuseram entre si os partidários da nova freguesia e os que na Vila estavam contra a autonomia de Santo Antão. Muitos desses incidentes conservam-se ainda na memória local, com relevo para a chamada «guerra dos marcos», um con- 
junto de confrontos verbais e físicos surgidos após a criação da freguesia de Santo Antão em torno da demarcação dos seus limites.

As Festas do Espirito Santo desempenharam justamente neste processo um importante papel. De facto, uma das primeiras e mais importantes expressões das reivindicações «autonómicas» de Santo Antão consistiu na ruptura do vínculo ritual que, por intermédio das Festas do Espirito Santo, a unia à Vila. Essa ruptura deu-se em 1884, antecipando portanto em 5 anos a criação oficial da freguesia. No decurso das Festas do Espírito Santo desse ano, a população de Santo Antão não só se recusou a participar, como era usual, nos festejos da Vila, como decidiu promover, à revelia do clero local e da população da Vila, aquela que se tornaria na primeira Festa do Espírito Santo circunscrita a Santo Antão.

Esse acontecimento é relatado com certo detalhe numa notícia de um jornal da época:

Em toda a ilha se festejou como é costume, no $1 .^{\circ}$ do corrente, o Divino Espírito Santo, distribuindo-se ao povo pão, bolos, tremoços, queijo e vinho.

No Topo, porém, onde estas festas se fizeram sempre com grande abundancia e entusiasmo, reunindo-se os povos dos diferentes arrabaldes da freguesia no antigo Império da vila, o que tornava um arraial digno de admirarse, no corrente ano, dividiram-se os povos em dois partidos, formando-se um novo Império de Santo Antão, povoação importante daquela freguesia.

Entre uns e outros entusiastas empregaram-se todos os meios, os da Vila contra a criação do novo Império e os de Santo Antão para levarem a efeito a ideia. Se os da Vila conseguiram o propósito de se não coroar o novo imperador de Santo Antão em dia tão memorável para os povos do curato, os de Santo Antão viram coroados de melhor êxito os seus desejos.

Negou-se o clero dafreguesia a concorrer com as cerimónias que em semelhantes actos se costumam realizar; o povo de Santo Antão, porém, não recuou, coloca a coroa no prato e em procissão, percorreu o curato entoando ao Divino Espirito Santo a oração da Ave Maria; distribuindo de tarde os seus 3.600 bolos, coscurões, tremoço, queijo e vinho entre alegres trovas ao som da classica viola.

E assim inaugurou aquela povoação o seu primeiro Império.

(O Velense, $n .^{\circ} 109$ de 8 de Julho de 1884)

A importância deste vínculo entre as Festas do Espírito Santo e a criação da freguesia de Santo Antão deve ser sublinhada. Configurando-se como um discurso ao serviço de um trabalho de reorganização cíclica das relações sociais, as Festas do Espírito Santo fornecem de facto um instrumento particularmente adequado para esse processo de radical reformulação de identidades sociológicas relativas que a criação da nova freguesia traduz.

Esta ligação entre as Festas do Espírito Santo e a autonomia da freguesia de Santo Antão mantem-se aliás viva na memória local. Para muitas pessoas, a razão da oposição da Vila à criação da freguesia de Santo Antão assentava nas Festas: «este povo já não ia para a Vila ajudá-los a fazer a festa». 
Nos anos imediatamente subsequentes à criação da freguesia de Santo Antão, as Festas do Espírito Santo continuaram ainda a desenhar um terreno preferencial para a expressão da rivalidade entre as duas freguesias. Alguns dos incidentes concretos então ocorridos foram registados pela imprensa da época. Outros fazem parte da memória oral da freguesia. Entre eles merece particular destaque o de uma família de Santo Antão que, insistindo em oferecer os seus bolos no Topo, em vez de o fazer em Santo Antão, acabou por ser objecto de uma pequena acção «punitiva» no seu regresso à freguesia. Mais uma vez demos a palavra à imprensa da época:

Na terça-feira do Espírito Santo à tarde, quando seguia da Vila para sua casa, o sr. ..., ao passar em Santo Antão, alguém mal intencionado, deitou uns foguetes próximo do carro em que ia a familia do dito, do que resultou espantarem-se os bois, com grave susto e grande perigo para as pessoas que conduziam.

(O Insulano $n{ }^{\circ} 268$ de 16 de Junho de 1900)

Historicamente assumida por contraposição ao Topo, a identidade de Santo Antão repousa ainda hoje em parte importante sobre esse confronto com a freguesia vizinha. E, tal como no século passado, as Festas do Espírito Santo continuam a desempenhar um importante papel nesse confronto, conduzido agora de uma forma mais «pacífica».

De facto, um dos aspectos mais interessantes da Festa de Pentecostes é o modo como ela dá lugar ao estabelecimento de uma relação de reciprocidade cerimonial entre as duas freguesias. Enquanto que em Santo Antão, o dia mais importante dos festejos e aquele em que ocorre a sua abertura ao exterior é, como vimos, a 2. ${ }^{a}$ feira de pentecostes, no Topo as mesmas cerimónias concentram-se na $3 .^{a}$ feira. Este arranjo possibilita que os habitantes das duas freguesias se visitem mutuamente messes dois dias: na 2. ${ }^{a}$ feira a população do Topo ocorre em grande número a Santo Antão, e, na 3. ${ }^{a}$ feira, é a vez de os de Santo Antão se deslocarem ao Topo.

Abandonadas as formas mais violentas de rivalidade é no terreno criado por esta relação de reciprocidade cerimonial que ambas as freguesias podem agora competir: confrontando pequenas diferenças na estruturação dos festejos, comparando o seu brilho relativo, e, sobretudo, procurando exibir uma generosidade e uma liberalidade acrescidas na distribuição dos alimentos.

Tal como em Santa Bárbara, o trabalho sociológico inscrito nas Festas do Espírito Santo de Santo Antão deve ser visto como um trabalho de reiteração cíclica das relações sociais. Esta sua característica recebia tradicionalmente 
um significado acrescido, resultante do modo como o período consagrado às Festas do Espírito Santo sobrevinha no seguimento das mudas. Estas consistiam em deslocações sazonais da população do seu habitat usual para as fajãs e nortes, que, como vimos, constituem povoações de ocupação temporária situadas respectivamente na costa sul e na costa norte (cf. mapa 16). A mais importante e significativa dessas deslocações ocorria justamente no decurso do inverno, entre meados de Janeiro e finais de Março, isto é, no período que antecedia as Festas do Espírito Santo ${ }^{1}$. As razões que estavam na sua base prendiam-se com alguns constrangimentos ecológicos que pesavam sobre a actividade agro-pastoril. Para as compreendermos torna-se necessário ter presente o facto de o povoamento em Santo Antão se desenvolver a mais de $300 \mathrm{~m}$, o que corresponde, nos Açores, a uma altitude considerável. Durante o período mais rigoroso do Inverno, a produtividade dos pastos tornava-se consequentemente muito reduzida. Devido às suas condições climatéricas mais amenas e temperadas e a uma maior produtividade dos solos, as fajãs e os nortes representavam uma alternativa a esse quadro.

Ora, além da sua componente geográfica e económica, as mudas possuíam também uma importante dimensão sociológica, expressa no conjunto de modificações a que submetiam a organização social local. Essas modificações operavam a vários níveis, desde os hábitos e as práticas mais quotidianas de sociabilidade até aos níveis mais estruturais do relacionamento social, como o lugar e a freguesia, cujos limites e identidade eram justamente postos em causa de forma radical. Relativamente ao lugar, as mudas implicavam não apenas o abandono desse espaço privilegiado de sociabilidade como determinavam uma suspensão das fronteiras e limites que ele impunha ao relacionamento social. De facto, ao mesmo tempo que dispersavam pelas diferentes fajãs e nortes os habitantes de um mesmo lugar, as mudas concentravam em cada um desses locais, pesssoas e casas provindas de diferentes lugares da freguesia. A identidade da freguesia era também profundamente afectada. Com efeito, um dos aspectos característico das mudas era o modo como elas envolviam, simultaneamente à população de Santo Antão, a população do Topo. Misturando a população das duas freguesias nas diferentesfajãs e nortes, as mudas «subvertiam» pois os limites e barreiras que usualmente as separavam, diluindo momentaneamente a identidade de cada uma delas.

Isto é: eram justamente as unidades sociais nomeadas pelas Festas do Espírito Santo que as mudas punham de alguma forma em questão. Um tal

\footnotetext{
${ }^{1}$ No fim do Verão, tinha lugar um movimento similar, mas de mais curta duração e envolvendo uma parte menos significativa da população. Para uma apresentação mais detalhada das mudas, cf. Bettencourt, 1988. O declínio das mudas parece estar ligado a dois factores principais: um deles resulta do aumento dos índices de produtividade nos pastos no decurso do inverno, devido à introdução de adubos; o outro resulta das consequências do sismo de 1981, que destruiu de forma irreparável as habitações de grande parte dos nortes.
} 
facto conferia uma importância acrescida ao trabalho sociológico inscrito nas Festas do Espírito Santo. Sobrevindo tradicionalmente no termo das mudas, este, além das características genéricas que ainda hoje lhe podem ser reconhecidas, propunha-se uma verdadeira re-composição dessas duas unidades sociais, após um período particularmente crítico do seu desenvolvimento.

E justamente a esta luz que é possível examinar o peso que ocupavam tradicionalmente nas Festas do Espírito Santo alguns mecanismos relacionados com a organização espacial dos festejos. Verificámos a importância desses mecanismos nas Festas, a propósito das casas de ver a festa. Orientadas para a reafirmação dos laços de pertença à freguesia e da sua identidade, as Festas articulavam-se com uma momentânea fixação da população no centro da freguesia que, envolvendo o abandono da residência habitual de parte dos habitantes da freguesia, desenhava um movimento simétrico e inverso ao das mudas. De forma embora diferente, esta dimensão espacial reencontrava-se também na série inicial de Jantares. De facto, quando as Coroas e outras insígnias do Espírito Santo eram instaladas em casa dos mordomos, uma parte dos festejos decorria então no próprio marco físico de cada um dos lugares, tornando em certa medida indissociáveis as vertentes sociológica e territorial da reconstrução da sua identidade. Ou seja: funcionando nas mudas como causa e suporte material do processo de «desagregação» do lugar e da freguesia, o espaço era simultaneamente utilizado nas Festas do Espírito Santo como um elemento simbólico dos propósitos de re-composição da organização social que nelas se inscreviam.

Simultaneamente, as Festas do Espírito Santo em Santo Antão articulam-se também com ideias de renascimento da natureza. Embora de uma forma menos expressiva do que em Santa Bárbara, elas reservam algum destaque a decorações florais de vário tipo, em particular no quadro dos cortejos que rodeiam a coroação. Como vimos, quer os ramos quer as varas que acompanham as Coroas são encimadas por uma decoração floral. As crianças que se integram nos cortejos transportam também consigo ramos de flores. E depois da coroação, quando as Coroas regressam ao Império, tem usualmente lugar uma pequena cerimónia em que as crianças que acompanham as Coroas lançam pétalas de flores sobre o mordomo e sobre as crianças ou adolescentes que foram coroados. Esta associação entre os festejos e a vegetação reencontra-se também em torno do alimento. No passado, era usual ornamentar o gado, antes do seu abate, com flores e ramos de verdura. E ainda hoje em dia, quer os pães de esmola, quer os pratos de doces distribuídos entre os irmãos e ajudantes de cada Gasto são também embelezados com flores. Finalmente, entre os motivos impressos nos bolos por intermédio dos chavões, ocupam também lugar de relevo, como vimos, os que representam flores estilizadas. Quanto às ideias de regeneração da fertilidade, elas exprimem-se com particular força no bodo de leite: é justamente na época do ano em 
que as Festas se realizam que a produção de leite, após ter decaído para níveis muito baixos no decurso do inverno, atinge o seu apogeu ${ }^{1}$.

Conotadas com ideias de regeneração cíclica da ordem social e natural, as Festas do Espírito Santo em Santo Antão, caracterizam-se, por fim, pelo relevo acrescido que concedem ao código etário. De facto, à semelhança da solução prevalecente nas freguesias da parte ocidental da ilha de Santa Maria - onde, como vimos, o menino da mesa, uma criança de quatro a oito anos de idade, constituía o protagonista principal da coroação — em Santo Antão é sobre um grupo de três crianças ou adolescentes que esta incide. Simultaneamente, um conjunto de outros aspectos dos festejos reforçam igualmente a importância do código etário. De facto, alguns dos desempenhos previstos nos cortejos que rodeiam a coroação - o transporte dos ramos, o transporte do espadim — são também assegurados por crianças ou adolescentes. E, a seguir à coroação, uma das secções mais importantes do cortejo que se forma é integrado por um numeroso grupo de crianças vestidas de branco.

A par desta acrescida importância do código etário, as Festas do Espírito Santo em Santo Antão colocam-nos perante a importância de um outro meio de simbolizar as ideias de renovação, baseado na exploração das potencialidades significantes da figura feminina. De facto, na escolha das crianças ou adolescentes que asseguram desempenhos tanto no quadro das coroações como no quadro dos cortejos que as rodeiam, existe uma marcada preferência por crianças ou adolescentes do sexo feminino. Da mesma maneira, no quadro do cortejo alegórico que antecede o bodo de leite, um dos carros mais em evidência é aquele onde seguem a rainha da festa e as respectivas damas de honor ${ }^{l}$.

\footnotetext{
${ }^{1}$ Este facto reflecte-se de forma expressiva nos dados referentes às entregas mensais de leite na Cooperativa Agrícola do Topo. Esta encontra-se fechada entre Janeiro e Março/ Abril, meses em que a produção de leite atinge o seu ponto mais baixo. Em Maio, o total de leite entregue é já muito significativo - cerca de de 338 mil litros em 1986 e 440 mil em 1987 para atingir o seu máximo anual em Junho — 355 mil litros em 1986 e 489 mil em 1987. Depois, a partir de Julho, as entregas de leite entram num movimento de declínio, que atingirá o seu ponto mais baixo em Dezembro - 25 mil litros em 1986 e 45 mil litros em 1987.

2 A importância dos desempenhos assegurados por crianças e adolescentes, em particular do sexo feminino, não apenas em Santo Antão, mas noutras freguesias e ilhas açorianas, tem sido por vezes entendida como uma consequência do efeito de «feed-back» das transformações operadas nas Festas do Espírito Santo, tal como estas são celebradas nos E.U.A., entre as comunidades de açorianos emigrados, sobre as Festas do Espírito Santo nos Açores. Isto é apenas parcialmente verdade. Tanto quanto é possível verificar, quer através do recurso à bibliografia mais antiga, como por intermédio da memória oral, essa tendência vem de trás. O que mudou foi, por um lado, o peso relativo desses desempenhos — cuja importância é agora maior - e, por outro lado, algumas das modalidades concretas de que estes se revestem. Assim, no caso de Santo Antão, se, como sublinhámos, a introdução da rainha dafesta e das damas de honor é claramente uma consequência da emigração, o peso mais geral dos códigos etário e sexual deve ser considerado, apesar das modificações que eventualmente tiveram lugar em tempos mais recentes, como um aspecto estrutural dos festejos.
} 
CAPÍTULO 10

COROAÇÕES E IMPÉRIOS

PIEDADE (PICO) 
Nossa Senhora da Piedade - ou Ponta da Piedade, ou ainda Piedade, como é também conhecida - é uma das dezassete freguesias em que se divide a ilha do Pico. Com uma área de $12,94 \mathrm{~km}^{2}$, a freguesia situa-se na ponta leste da ilha, fazendo parte do concelho das Lajes e tinha em 1989 um total de 855 habitantes e 259 unidades domésticas. Destas, cerca de $72 \%$ correspondiam a agregados familiares simples, enquanto os agregados familiares alargados e múltiplos representavam respectivamente $15 \%$ e $6 \%$ do total; os isolados correspondiam a $7 \%$ e os agregados não conjugais a $2 \%$ das unidades domésticas ${ }^{1}$. O povoamento é predominantemente disperso e a população distribui-se por um conjunto de lugares entre os quais avultam os Fetais, a Manhenha, a Ponta da Ilha, Altamora, o Curral da Pedra, o Caminho de Cima e o Calhau (cf. quadro 28). Afectada pela emigração - que se traduziu num decréscimo, entre 1960 e 1981, de $24 \%$ da população ${ }^{2}$ - a freguesia possui um modo de vida assente na agricultura e na criação de gado, desempenhando também a pesca um papel importante na actividade dos seus habitantes.

$\mathrm{Na}$ Piedade, a estrutura genérica das Festas do Espírito Santo compreende, como em Santo Antão, dois tipos distintos de festejos: por um lado, as Coroações - também designadas por Gastos de Coroa ou por Jantares por outro, os Impérios. As Coroações tinham tradicionalmente lugar em todos os domingos compreendidos entre o domingo de Páscoa e o Pentecostes e

\footnotetext{
${ }^{1}$ Estes dados foram obtidos através da consulta dos registos paroquiais, complementada com informação oral recolhida junto de alguns informantes chave.

2 A população da freguesia da Piedade era, em 1960, de acordo como os dados do Recenseamento Geral da População, de 1293 habitantes e 374 fogos. No cálculo deste número, descontei os habitantes da Ribeirinha, que, embora nessa ocasião fosse um dos lugares da freguesia da Piedade, se veio a tornar, em 1981, numa freguesia autónoma.
} 
AS FESTAS DO ESPÍRITO SANTO NOS AÇORES

\begin{tabular}{|c|c|c|}
\hline LUGAR & UNIDADES DOMÉSTICAS & HABITANTES \\
\hline Fetais & 61 & 223 \\
\hline Manhenha & 11 & 34 \\
\hline Ponta da Ilha & 56 & 188 \\
\hline Altamora & 46 & 135 \\
\hline Curral da Pedra & 12 & 48 \\
\hline Caminho e Cima & 19 & 58 \\
\hline Calhau & 54 & 169 \\
\hline Totais & 259 & 855 \\
\hline
\end{tabular}

QUADRO 28

Distribuição da população por lugares (Piedade, 1989)

ainda no domingo de Pentecostes e $2 .^{a}$ feira de Pentecostes e no domingo da Trindade. A designação reservada para o conjunto deste período era a de folia. Até há cerca de 40 anos tinha também lugar uma Coroação na 5. ${ }^{a}$ feira de Ascensão. Hoje em dia, e desde há cerca de 20 anos, deixaram de se realizar Coroações nos domingos anteriores ao Pentecostes. Em contrapartida passaram a realizar-se algumas Coroações fora do tempo, promovidas por emigrantes. Quanto aos Impérios recaem sobre o domingo e 2. ${ }^{\mathrm{a}}$ feira de Pentecostes e o domingo da Trindade, realizando-se em simultâneo com as Coroações desses dias.

As Coroações resultam de promessas individuais em que, para além de razões relacionadas com a saúde, surgem recorrentemente motivos associados aos perigos da vida do mar. A sua frente encontra-se um mordomo. Ao longo da semana em que decorrem os festejos, o mordomo entra momentaneamente na posse dos emblemas do Espírito Santo: duas Coroas, três estandartes e um espadim ${ }^{x}$. Tradicionalmente, estas insígnias eram instaladas em casa do mordomo, num altar erguido para o efeito. Recentemente, porém, generalizou-se o recurso ao salão paroquial, que funciona como o equivalente da copeira em Santa Bárbara ou da Casa do Espírito Santo em Santo Antão.

$\mathrm{Na}$ sua vertente religiosa, as Coroações compreendem, por um lado, a realização diária do terço, junto ao altar do Espirito Santo. Este é cantado e estrutura-se de acordo com uma modalidade tradicional cujas linhas gerais se reencontram tanto noutras freguesias do Pico como noutras ilhas do grupo central. Essa modalidade prevê, em primeiro lugar, a substituição da Ave Maria

\footnotetext{
${ }^{1}$ Das duas Coroas existentes na freguesia, uma é mais recente e foi oferecida por um emigrante; o espadim foi também oferecido, em 1889, por um emigrante, o mesmo sucedendo com um dos estandartes.
} 


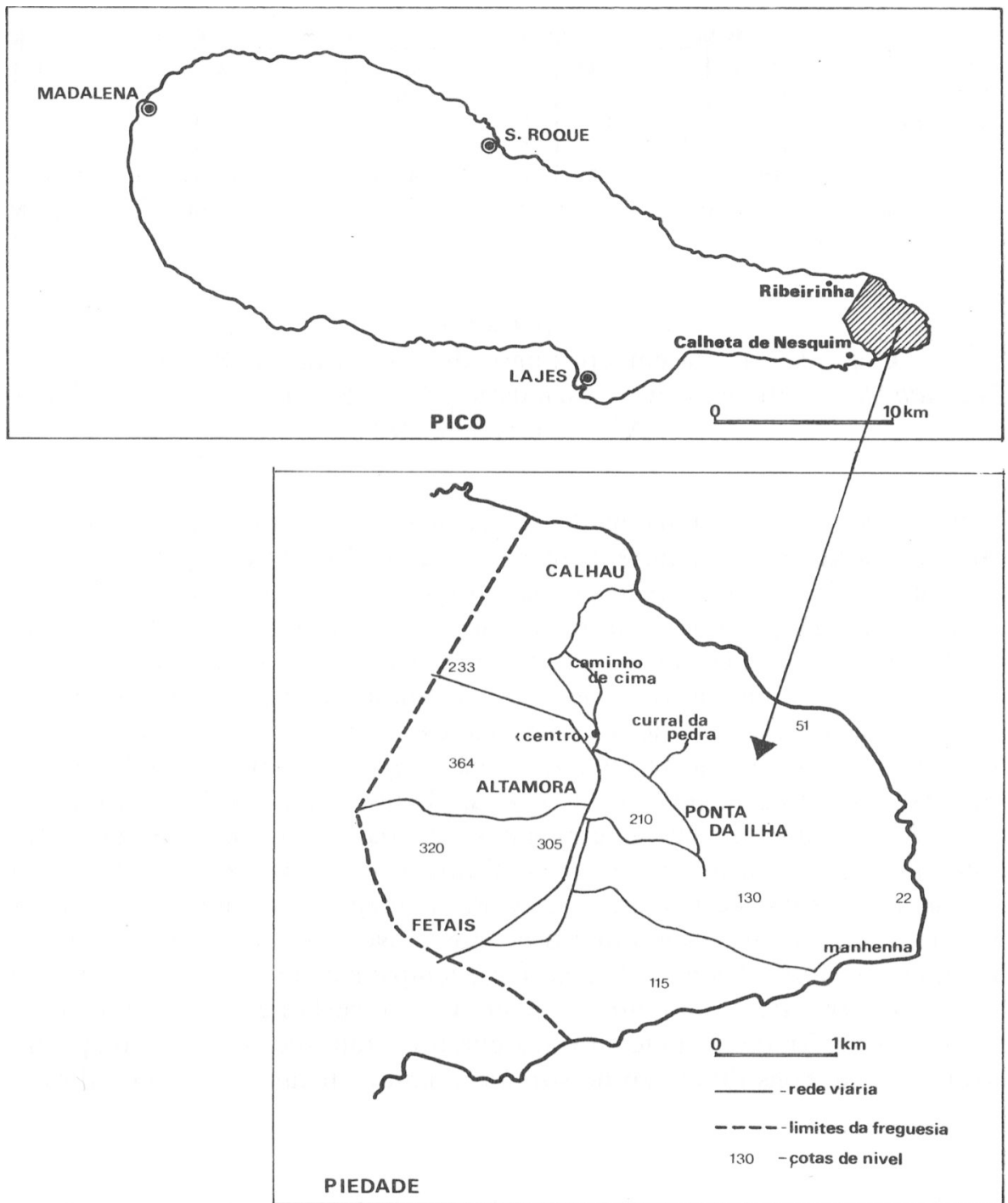

MAPA 17

Freguesia de Nossa Senhora da Piedade (Pico)

por um pequeno cântico de louvor ao Espírito Santo ${ }^{1}$. E comporta, em segundo lugar, a entoação final da Salve Rainha dobrada, um cântico construído a

${ }^{1}$ É a seguinte a letra desse cântico: «Adoremos com afectos de alma/ ao Espírito Santo divino/ do céu descei sobre nós/ com auxílios do amor divino». 


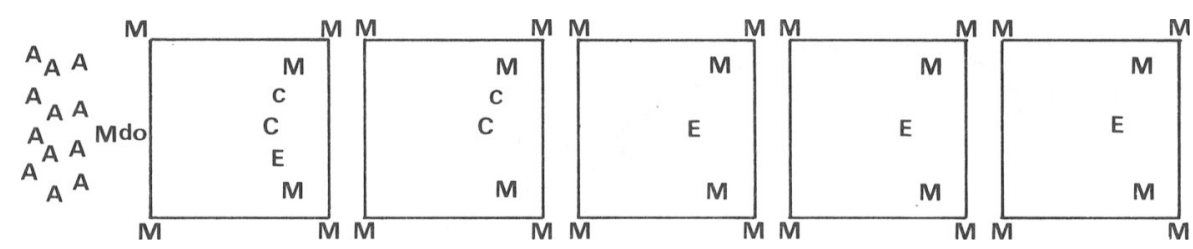

FIGURA 9

Organização do cortejo que rodeia a coroação (Piedade)

Legenda: M - crianças; E - estandartes; C - coroas; Mdo - mordomo, A - acompanhantes.

partir da Salve Rainha. Finalmente, no decurso ou na parte final do terço, são cantadas várias orações, entre as quais avulta a «Oração ao Espírito Santo», em que se solicita a protecção divina em relação a terramotos ${ }^{1}$.

No domingo, por seu turno, realiza-se a coroação propriamente dita. Esta incide sobre duas crianças ou adolescentes escolhidos geralmente entre os filhos do mordomo e realiza-se no termo da missa. Os cortejos que a rodeiam obedecem a um certo número de constantes. A frente seguem três quadros formados com varas, no interior dos quais seguem os três estandartes. De seguida vêm os dois quadros das Coroas. Estes quadros são formados por crianças, com predominância de meninas, vestidas geralmente de branco. Em cada um deles, além das crianças que formam o quadro propriamente dito e das que conduzem os estandartes e as Coroas, integram-se também duas meninas que transportam consigo ramos de flores. No termo do cortejo, por fim, incorpora-se o mordomo - que se faz acompanhar de uma vara própria, a chamada vara do mordomo - seguido do restante acompanhamento (cf. figura 9). Tradicionalmente estes cortejos eram dirigidos e acompanhados pela folia, constituída por doisfoliões: um que tocava o tambor e dirigia,

É o seguinte o texto dessa oração: «Ó senhor Espírito Santo/ vos roguemos com clamor/ mandai prevenir a terra/ que não haja mais tremor// Sois pai de misericórdia/ livrai-nos de todo o mal/ não nos mateis com tremor/ nesta ilha de orfandade// Meus pecados são a causa/ da terra tanto tremer/ agora vos prometemos/ nunca mais vos ofender// Não despreseis a fé grande/ que é ao que nós recorremos/ fazei como pai benigno/ não por nós o merecermos// Minha senhora soberana/ das mercês do pecador/ o senhor Espírito Santo/ Seja o nosso intercessor// Rogai com afecto d'alma/ Espírito Santo divino/ do céu desçam sobre nós / sucessos do amor mais fino// Glória seja ao Pai/ ao Filho que nos remiu/ ao senhor Espírito Santo/ que de graças nos cobriu// Ó Santíssima Trindade/ sois esposa, mãe e filha/ peço-vos misericórdia/ para toda esta ilha// A vossa misericórdia/ que do céu queira gozar/ não nos mateis com tremores/ nesta ilha de orfandade// Toda nossa esperança/ nós pomos em vós senhor/ ó senhor Espírito Santo/ ouvi a quem vos adora.». 
e outro que apenas cantava. De acordo com a tendência mais geral prevalecente nos Açores, designadamente nas ilhas do grupo central, a folia entrou entretanto em declínio, tendo sido substituída por uma filarmónica ${ }^{1}$.

Quanto à componente alimentar das Coroações, ela assenta na preparação de um certo número de alimentos que, na Piedade, incluem: pão de trigo, pão de ovos - preparado sob a forma de pão da mesa e de biscoito - rosquilhas, pão leve, arroz doce, Sopas do Espirito Santo e carne assada ${ }^{2}$. Estes alimentos - aos quais há que acrescentar ainda o vinho - requerem um dispêndio importante de géneros - uma ou duas reses, 250 a $300 \mathrm{~kg}$ de farinha, entre 200 a 300 dúzias de ovos, 3 a 4 quintos de vinho, etc... - e representam hoje em dia um gasto médio situado entre os 200 e os 300 contos $^{3}$. Este gasto é suportado fundamentalmente pelo mordomo, que recebe entretanto um certo número de visitas em géneros (ovos, açúcar, farinha) ou em dinheiro. Quanto á confecção culinária doa alimentos, está, como em Santo Antão, a cargo de dez a doze ajudantes femininas, dirigidas por uma mestra; o abate e a preparação prévia das reses competem por seu turno a um grupo de ajudantes masculinos - os matadores - dirigidos por um marchante.

A prestação alimentar central das Coroações é constituída pelo jantar. uma grande refeição, reservada aos convidados do mordomo - entre cem a duzentos -, que consta de Sopas do Espírito Santo, carne assada, pão da mesa, pão leve e arroz doce. A refeição realiza-se no termo da missa de coroação e tem actualmente lugar no salão paroquial. Além dojantar, as Coroações envolvem ainda um conjunto de outras prestações alimentares. A mais importante dessas prestações resulta geralmente de uma promessa específica feita nesse sentido e consta de uma distribuição de esmolas - compostas por um pedaço de carne de rês crua, um biscoito e um litro de vinho - entre duas a três dezenas de casas mais pobres da freguesia. Essas esmolas são previamente benzidas pelo padre, sendo repartidas porta-a-porta no decurso da tarde de sábado. Uma outra prestação consiste numa distribuição porta-a-porta de Sopas do Espírito Santo. Esta distribuição tem lugar na madrugada de domingo e abrange as casas que fizeram visitas ao mordomo. Finalmente, os ajudantes recebem também em sua casa uma posta de carne crua e um biscoito.

\footnotetext{
${ }^{1}$ Em 1989, a filarmónica existente na freguesia ericontrava-se momentaneamente desactivada e as Coroações realizaram-se sem qualquer acompanhamento musical.

${ }^{2}$ Cada fornada de pão de ovos requer $8 \mathrm{~kg}$. de farinha, 4 dúzias de ovos, $2 \mathrm{~kg}$. de açúcar, $1 \mathrm{~kg}$. de manteiga, a raspa de um limão grande, fermento e eventualmente 1 cálice de aguardente e um pouco de leite. Enquanto o pão de mesa é maior e mais sobre o comprido, o biscoito possui um formato arredondado. Quanto às rosquilhas, cada fornada - 4 ros quilhas requer $5 \mathrm{~kg}$. de farinha, 3 dúzias de ovos, $1 \mathrm{~kg}$. de açúcar, $V i \mathrm{~kg}$. de manteiga, 1 raspinha de limão, nos moscada, 1 cálice de aguardente e fermento. As Sopas do Espírito Santo, por seu turno, são feitas à base de carne de rês cozida e pão de trigo e são condimentadas com canela, tomatada, alho, cebola e sal.

${ }^{3}$ Os números apresentados tomam como ano de referência 1989.
} 


\begin{tabular}{|c|c|c|c|c|}
\hline PONTOS & IRMÃOS & BOLOS & $\begin{array}{l}\text { TOTAL DE } \\
\text { VINHO }\end{array}$ & $\begin{array}{l}\text { OFERTAS } \\
\text { DINHEIRO }\end{array}$ \\
\hline Domingo de Esp. St. ${ }^{\circ}$ & 57 & 1057 & 44 potes & $62000 \$ 00$ \\
\hline 2. ${ }^{\mathrm{a}}$. Feira de Esp. St. ${ }^{0}$ & 67 & 1275 & 29 potes & $73000 \$ 00$ \\
\hline Domingo da Trindade & 58 & 800 & 30 potes & $95000 \$ 00$ \\
\hline
\end{tabular}

\section{QUADRO 29 \\ Pontos e ofertas nos Impérios (Piedade, 1989)}

Quanto aos Impérios, eles estruturam-se em torno de um conjunto de distribuições generalizadas de bolos - ou vésperas ${ }^{1}$ - e de vinho que têm lugar nas tardes de domingo e $2 .^{\text {a }}$ feira de Pentecostes e de domingo da Trindade. Essas distribuições realizam-se a partir da Capela do Espírito Santo - designação local atribuída ao edifício genericamente conhecido no grupo central por Império - onde as Coroas ficam em exposição. Simultaneamente, tem lugar um arraial, com exibições de filarmónicas, arrematações, comes e bebes, etc...

$\mathrm{Na}$ base dos Impérios e, em particular, da distribuição generalizada de bolos e vinho que constitui o ponto central dos festejos, encontram-se três pontos, conhecidos pelas designações de ponto de Domingo, ponto de 2. ${ }^{a}$ feira e ponto da Trindade. Cada um destes pontos tem à sua frente uma direcção composta por três elementos ${ }^{2}$ e define-se como uma espécie de irmandade formada por um certo número de casas da freguesia que, através de ofertas tradicionalmente regulamentadas, asseguram o financiamento das distribuições de bolos e vinho que intervêm em cada um dos dias. Essas ofertas são feitas em vinho, em bolos ou em dinheiro, de acordo com quantidades tradicionalmente estipuladas: um pote de vinho (12 litros) e meia conta de bolos - correspondente a vinte e cinco bolos - ou $2.500 \$ 00$ em dinheiro. No ponto de 2. ${ }^{a}$ feira, entretanto, a oferta em vinho é de apenas 5 litros e, em 1989, o quantitativo em dinheiro com que cada irmão contribuía para os festejos foi

\footnotetext{
${ }^{1}$ Este bolos, são também conhecidos pela designação de vésperas e são muito parecidas com as usadas em Santo Antão. Para a confecção de 44 desses bolos são necessários $22 \mathrm{~kg}$. de farinha, 4 dúzias de ovos, $2 \mathrm{~kg}$. de açúcar e fermento. De feitio redondo e achatado, as vésperas são embelezadas, antes de irem ao forno, com motivos diversos, impressos na massa por intermédio de chavões de madeira.

${ }^{2}$ Há cerca de 30 anos atrás, cada ponto tinha à sua frente o chamado cabeça de pelouro, assessoreado por dois mordomos, um encarregue do vinho e outro dos bolos. Hoje em dia, tanto estas designações como a divisão de trabalho que elas pressupõem caíram em desuso: a direcção de cada ponto, renovada todos os 2 ou 3 anos, tem à sua frente um presidente eleito pelos irmãos que escolhe dois outros indivíduos para o auxiliarem.
} 
fixado em $5.000 \$ 00$. Como se pode verificar no quadro 2 , é bastante significativo o número de casas que, em cada ponto, contribuem para o Império respectivo, assim como os quantitativos globais de alimentos e dinheiro obtidos.

A entrega formal destes alimentos - em particular dos bolos - ao Império faz-se por intermédio de um conjunto de cortejos organizados especificamente para o efeito, que têm lugar ao fim da manhã de cada um dos dias em que recaem os festejos, e no termo dos quais os alimentos são benzidos pelo padre. Encabeçados pelas Coroas e pelos estandartes, esses cortejos são compostos por duas filas integradas por algumas dezenas de irmãos do ponto que asseguram o transporte dos bolos oferecidos ao Império. Os bolos são geralmente transportados em açafates levados à cabeça, sendo profusamente decorados com flores. Num desses cortejos - o de 2. ${ }^{a}$ feira do Espírito Santo - procede-se também ao transporte, num carro de bois decorado, do vinho necessário aos festejos.

Além do papel que desempenham nos Impérios, os pontos ligam-se ainda às Coroações que têm lugar nesses dias. Esse nexo diz em primeiro lugar respeito às modalidades organizativas a que estas últimas obedecem. Os mordomos que as asseguram fazem parte do ponto respectivo, estando também prevista a possibilidade de vários irmãos do mesmo ponto se associarem entre si para organizarem conjuntamente uma Coroação. Finalmente, em caso de inexistência de promessas, é o ponto no seu conjunto que toma a seu cargo a realização da Coroação. A relação entre os pontos e as Coroações de domingo e 2. ${ }^{\text {a }}$ feira de Pentecostes e domingo da Trindade estende-se em segundo lugar à vertente religiosa dos festejos. Assim, os cortejos que rodeiam a Coroação são geralmente integrados por um grande número de irmãos do ponto. Inversamente, no cortejo que assegura o transporte cerimonial dos bolos e do vinho para a Capela do Espírito Santo, o transporte dos estandartes e das Coroas é assegurado pelo «séquito» do mordomo. O vínculo entre os pontos e as Coroações estende-se por fim à vertente alimentar dos festejos. Como se pode verificar no quadro 30 , as visitas ao mordomo - que são geralmente em maior número do que nas restantes Coroações - atingem também no

\begin{tabular}{lcc}
\hline COROAÇÃO & TOTAL & PERCENTAGEM \\
& DE VISITAS & $\begin{array}{c}\text { DE VISITAS FEITAS } \\
\text { NO QUADRO DO PONTO }\end{array}$ \\
\hline Domingo de Esp. Santo & 86 & $50 \%$ \\
2. ${ }^{\text {. Feira de Esp. Santo }}$ & 98 & $45 \%$ \\
Domingo da Trindade & 70 & $57 \%$ \\
\hline
\end{tabular}

QUADRO 30

Coroações, visitas e pontos (Piedade, 1989) 
ponto uma densidade significativa. Parte do vinho necessário aojantar é igualmente fornecido pelo ponto, a partir das ofertas feitas pelos irmãos. Finalmente, os irmãos do ponto são obrigatoriamente convidados para ojantar, ocupando nele uma mesa própria, distinta da dos restantes convidados.

Tradicionalmente as Coroações que tinham lugar no domingo e 2. ${ }^{a}$ feira de Pentecostes e no domingo da Trindade compreendiam ainda o serviço: «organizava-se um pequeno grupo composto por dois moços de destaque no lugar, tendo cada um uma toalha comprida, de alvo linho, altas rendas e laços de fita vermelhas presa no ombro esquerdo. Com eles iam os foliões e alguns irmãos com suas varas, incumbindo-lhes, em primeiro lugar, levar as alcatras assadas e duas grandes argolas de massa sovada ao vigário e seu cooperador. O resto da cerimónia constava de bolos doces, confeitos e amêndoas, limões e outras frutas próprias da estação que (...) eram distribuídas pelas pessoas mais em evidência, que geralmente deitavam uns cobres no prato» (Coelho, M., 1961: 345$)^{1}$.

Em torno desta estrutura dos festejos é possível reencontrar de novo um conjunto de motivações de natureza religiosa, resultantes mais uma vez da conjunção de formas de religiosidade de características simultaneamente individuais e colectivas. É com base nas primeiras que se realizam as Coroações, resultantes, como vimos, de promessas individuais. Quanto às segundas, elas exprimem-se sobretudo nos Impérios, ligados a ideias de bemestar colectivo que, na Piedade, surgem ainda hoje difusamente associadas ao vulcanismo. Como vimos, uma das orações entoadas no âmbito do terço tem justamente como objectivo solicitar a protecção do Espírito Santo em relação a terramotos e erupções vulcânicas. Por outro lado, certos aspectos relacionados com as origens das Festas do Espírito Santo na freguesia são também frequentemente ligados a algumas das crises vulcânicas que a ameaçaram. Duas dessas crises misturam-se nas narrativas orais. Uma refere a erupção de 1801 na Urzelina (São Jorge). Extremamente violenta - a maior parte da povoação da Urzelina ficou então soterrada - essa erupção era visível do Pico e, segundo se conta na freguesia, "os antigos fizeram então a promessa de fazer um Império na 2. ${ }^{a}$ feira do Espírito Santo, se o lume não chegasse ao Pico». Noutras narrativas, entretanto, esta mesma promessa

\footnotetext{
${ }^{1}$ Hoje em dia, apesar de esta cerimónia ter desaparecido, mantem-se a oferta ao pároco e aos sacristãos. Esta consta de uma rosquilha e é geralmente efectuada na véspera do dia em que recaem os festejos.
} 
é apresentada como resultante da erupção vulcânica ocorrida, em 1718, no Pico, nas freguesias de Bandeiras e Santa Luzia.

Tanto no plano individual como no plano colectivo, é também sobre o dispêndio de alimentos requerido pelos festejos que repousa em grande medida o vínculo que elas estabelecem com a divindade. E a este respeito significativo que uma das versões sobre a ligação entre as Festas do Espírito Santo e as crises vulcânicas atrás referidas faça remontar a essas ocasiões não apenas a celebração do Império de $2 .^{\text {a }}$ feira de Pentecostes mas, de uma forma mais ampla, o conjunto das distribuições de bolos e vinho associadas aos Impérios.

Ao mesmo tempo, as Festas do Espírito Santo na Piedade possuem uma importante vertente sociológica, apoiada mais uma vez na linguagem da dádiva alimentar. Essa vertente sociológica expressa-se também em dois níveis distintos: um relacionado com esferas sociais de carácter mais restrito, ligadas às figuras individuais de cada um dos mordomos, outro relacionado com círculos sociais mais amplos.

$\mathrm{O}$ vínculo entre as Festas do Espírito Santo e esferas mais restritas de sociabilidade - parentesco, vizinhança, amizade - é estabelecido por intermédio das Coroações e começa por assentar nas modalidades em que se baseia a formação do grupo de ajudantes. Mas é sobretudo em torno dos critérios que presidem à escolha dos convidados para ojantar que ele transparece mais claramente. Cada mordomo procura que esses convites cubram de forma mais ampla possível a sua rede de relacionamento social, com destaque para as relações baseadas no parentesco. Estas podem constituir entre 20 a 30\% do total de unidades domésticas representadas. Números idênticos reencontram-se em torno das visitas feitas a cada um dos mordomos. E é também entre os membros destas unidades domésticas que são preferencialmente recrutados as crianças e adolescentes que integram os quadros. Finalmente, são ainda mecanismos ligados ao parentesco que presidem em muitos casos à formação das companhas que tomam a seu cargo a realização de Coroações colectivas. Foi o que sucedeu em 1989, com a Coroação de domingo do Espírito Santo. Esta tinha à sua frente um grupo de cinco mordomos estreitamente aparentados, constituído por um pai, dois filhos casados, um genro e um sobrinho. O pai pagou a carne e os outros parentes repartiram entre si as restantes despesas. Cada um convidou entre vinte cinco a trinta pessoas para ojantar e superintendeu a formação de um quadro próprio, com crianças por ele convidadas.

Paralelamente a esta vertente sociológica mais restrita, as Festas do Espírito Santo na Piedade ligam-se também a ideias de reiteração das instâncias mais globais sobre as quais assenta o sistema social local: o lugar, por um lado, e a freguesia, por outro. Mas enquanto que em Santo Antão, estas ideias eram dadas, ao longo do conjunto dos festejos, pela sucessão Jantares!Festas, no caso da Piedade elas exprimem-se sobretudo na fase final dos festejos, coincidente com o domingo e $2 .^{\text {a }}$ feira de Pentecostes e com o domingo da Trindade. Subjacentes tanto às Coroações desses dias como aos Impérios estão, como vimos, um conjunto de três pontos. Ora, por detrás de cada ponto é uma área 


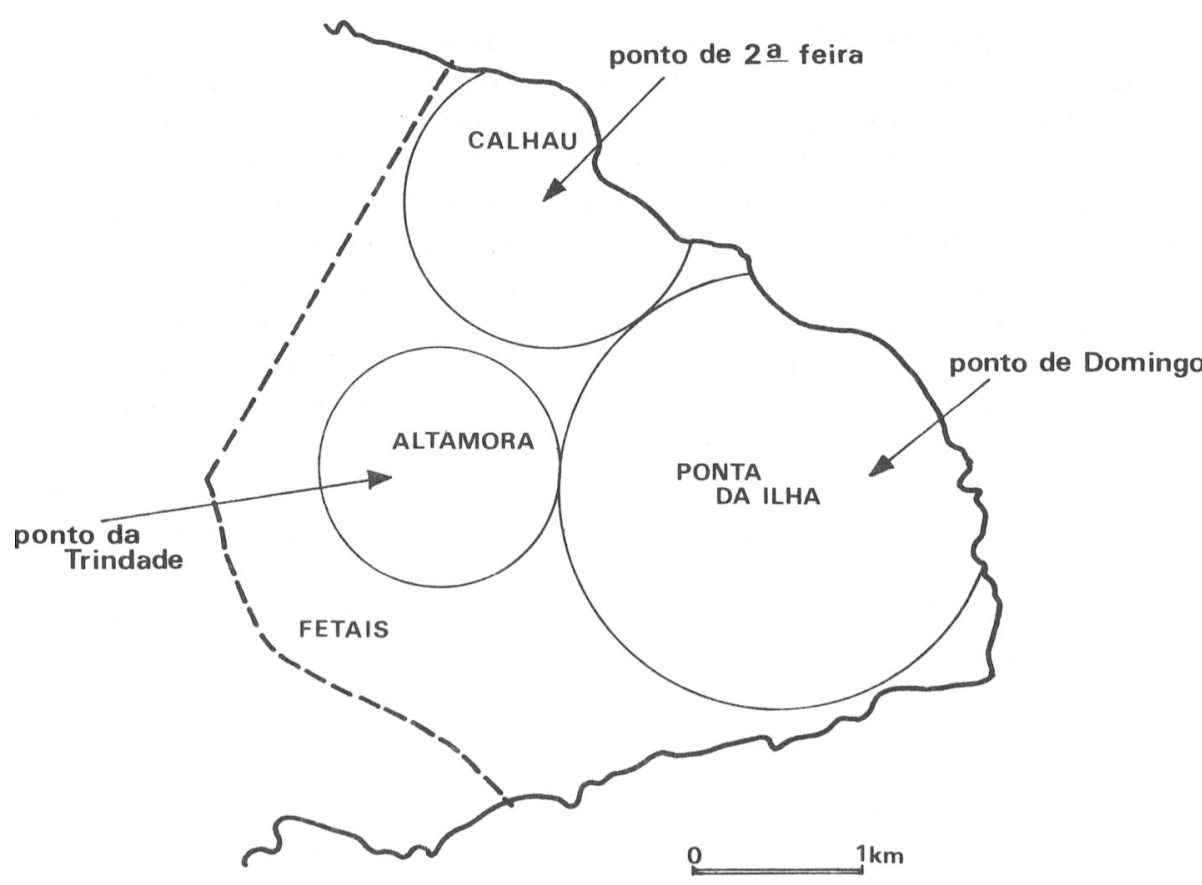

MAPA 18

Pontos e lugares nas Festas do Espírito Santo na Piedade

específica da freguesia, polarizada em torno de um lugar preciso, que se encontra (cf. mapa 18). O ponto de domingo corresponde à área designada por Ponta da Ilha: $81 \%$ dos irmãos é lá residente. O ponto de $2{ }^{a}$ feira é integrado maioritariamente por irmãos do Calhau: cerca de $97 \%$ do total. O ponto da Trindade, por fim, liga-se a Altamora, que fornece $48 \%$ dos irmãos. Em cada uma destas áreas é também bastante significativa a proporção de casas que fazem parte dos respectivos pontos: $81 \%$ na Ponta da Ilha, $88 \%$ no Calhau e $52 \%$ em Altamora. Esta organização da freguesia em circunscrições rituais acompanha de perto a própria realidade sociológica. De facto, os lugares mencionados constituem os lugares mais importantes da freguesia. E por relação a eles que outros lugares menores - Manhenha, Curral da Pedra, Caminho de Cima, etc... - se definem. E são também eles que, no plano matrimonial, definem as áreas onde a endogamia de lugar atinge proporções mais significativas: $44,4 \%$ no Calhau e $35 \%$ na Ponta da Ilha. Significativamente, Altamora, que constitui o ponto com uma ligação mais 
fraca à realidade do lugar, é também o lugar onde a endogamia atinge proporções mais baixas: apenas $12,8 \%^{\wedge}$

$\mathrm{O}$ vínculo existente entre lugares e pontos começa por reflectir-se nas Coroações que se realizam no domingo e $2 .^{\text {a }}$ feira de Pentecostes e no domingo da Trindade. Simultaneamente às características gerais que lhes reconhecemos anteriormente estas definem-se ainda como uma celebração que reforça os laços sociais no âmbito do lugar. Este assume-se, por um lado, como o principal parceiro colectivo do mordomo no dispêndio requerido pela Coroação. De facto, como vimos, além de uma comparticipação importante na despesa com o vinho requerida pelo jantar, o ponto contribui ainda com uma proporção importante das visitas recebidas por cada um dos mordomos. Em média, entre 30 a $40 \%$ da despesa requerida por estas Coroações é directa ou indirectamente suportada pelo ponto. Proporcionalmente às responsabilidades que assume no financiamento dos festejos, o lugar constitui por outro lado uma das esferas sociais onde a circulação cerimonial do alimento atinge proporções mais importantes. De facto, além das Sopas que os irmãos que realizaram visitas recebem em sua casa, pelo menos um dos membros de cada unidade doméstica que faz parte do ponto deve ser, como vimos, convidado para o jantar. Este recebe, em consequência, características de uma refeição colectiva extensiva ao lugar.

E de acordo com pressupostos similares que podem também começar por ser encarados os Impérios. Financiando as distribuições de bolos e vinho que constituem o seu núcleo central, cada lugar assume à vez um papel de doador colectivo de alimentos que lhe permite vincar a sua identidade no quadro da freguesia. Esta faceta dos festejos exprimia-se de forma particularmente clara no percurso tradicional a que obedeciam os cortejos ligados à entrega dos alimentos na Capela do Espírito Santo. Tendo o seu início num dos extremos da área recoberta pelo ponto, esses cortejos percorriam depois o conjunto dessa área recolhendo as ofertas das diferentes casas - para depois se encaminharem para o centro, onde eram aguardados pelos restantes moradores da freguesia. Por seu intermédio, era a própria identidade territorial de cada ponto que era sublinhada.

Ao mesmo tempo que se ligam a ideias de reiteração dos laços sociais no âmbito de cada lugar, os Impérios ligam-se também à reafirmação da identidade da freguesia. Dependendo exclusivamente do ponto no tocante ao financiamento das distribuições alimentares que o integram, os Impérios fornecem em primeiro lugar o contexto para uma grande refeição colectiva extensiva ao conjunto da freguesia. E de facto no quadro desta que o alimento começa privilegiadamente por circular. A hora prevista para o início das distribuições de bolos e vinho é grande o ajuntamento de vizinhos nas imediações da Capela do Espírito Santo. Tradicionalmente era mesmo usual que muitas

\footnotetext{
1 Os dados relativos à taxa de endogamia foram obtidos através da consulta dos assentos paroquiais de casamentos e dizem respeito aos anos de 1948 a 1987. Por ausência de indicações relativas ao lugar de residência dos noivos não foram levados em conta os anos de 1963, 1964 e 1968 a 1982. No total, a amostragem realizada incide sobre um conjunto de 284 casamentos.
} 
famílias trouxessem de casa biscoitos confeccionados para a ocasião que eram informalmente partilhados com parentes ou conhecidos e que eram consumidos em conjunto com os bolos e o vinho distribuídos no quadro do Império. Simultaneamente, a circulação do alimento é extensiva aos forasteiros, que afluem em grande número. Tal como verificámos anteriormente, o alimento funciona também aqui como um signo do prestígio colectivo da freguesia, que permite que esta, no preciso momento em que se assume como tal, o possa fazer por confronto com um parceiro colectivo outro. O facto de grande parte dos forasteiros ser proveniente de freguesias do Pico onde este tipo de distribuições generalizadas consta, em vez de bolos, de rosquilhas, é particularmente posto em relevo, sendo interpretado como uma espécie de reconhecimento tácito da «superioridade» dos bolos em relação às rosquilhas.

\section{III}

O sistema que acabámos de passar em revista apresenta uma «anomalia» importante que até agora deixámos na sombra. Essa anomalia prende-se com o estatuto periférico ocupado na estrutura geral dos festejos pelo lugar dos Fetais. Esse estatuto periférico começa por se exprimir no facto de os Fetais se encontrarem excluídos do sistema de pontos. Embora os testemunhos orais sejam algo imprecisos, essa exclusão parece datar de há 70 ou 80 anos. Até essa altura, os Fetais integravam-se no ponto da Trindade, que cobria portanto toda a mancha sul da freguesia e não, como sucede agora, apenas o lugar de Altamora (cf. mapa 18). No seguimento de um incidente grave em que um grupo de homens dos Fetais foi acusado da morte de um outro morador da freguesia, o lugar deixou então de fazer parte desse ponto. Na base desse incidente esteve o incêndio da primitiva Capela do Espírito Santo, então em madeira. Esse incêndio ocorreu nas vésperas do Império da Trindade e gerou um conjunto de suspeições e acusações cruzadas na freguesia. Os dos Fetais acusavam pessoas exteriores ao lugar, interessadas em prejudicar o brilho dos festejos - que nessa semana estavam a cargo de um mordomo dos Fetais - enquanto que no resto da freguesia se atribuía a autoria do incêndio aos dos Fetais. Quando os moradores deste lugar se dirigiram ao centro para levantar a Coroa, os ânimos estavam excitados e esta foi-lhes negada. Ao retroceder, o grupo foi alvo de provocações por alguns indivíduos e as duas partes envolveram-se em conflito do qual resultou a morte de um desses indivíduos. Este incidente encontra-se mais detalhadamente descrito no estudo da autoria de Manuel Ávila Coelho consagrado à freguesia da Piedade. Depois de referir o incêndio da Capela o autor prossegue: «ora isto aconteceu entre a segunda-feira de Espírito Santo e o Domingo da Santíssima Trindade, dia em que os habitantes do lugar dos Fetais faziam o seu Império. 
Daqui nasceram duas desconfianças: uma nos lugares do Calhau e Ponta da Ilha, onde se julgava estar nos Fetais o autor da façanha: outra nos Fetais, onde se pensou que o causador do incêndio estava no Calhau ou Ponta da Ilha, para que não pudessem fazer o seu Império com a casa destruída! Neste estado de espírito um grupo dos Fetais veio ao Calhau reclamar a coroa que lhe foi negada e ao dirigir-se ordeiramente para casa foi apupado por um indivíduo que conversava com o filho do. . . . e que fugiu a tempo. Os do grupo, retrocedendo, envolveram-se em desordem com o rapaz que estava inocente. Deu-se então o desastre quando o. . . acudiu aos gritos do filho — uma pedra, que o atingiu na cabeça, fulminou-o» (Coelho, M. ${ }^{\mathrm{a}}$., 1961: 328).

Vendo-se excluídos do sistema geral dos festejos à escala da freguesia, os moradores dos Fetais passaram então a promover Impérios próprios no domingo e 2. ${ }^{\text {a }}$ feira de Pentecostes e no domingo da Trindade. À semelhança da freguesia, o lugar foi dividido em três pontos, cada um dos quais tinha a seu cargo os festejos no dia respectivo. Posteriormente, a par destes Impérios, passou também a realizar-se na 5. ${ }^{\mathrm{a}}$ feira do Corpo de Deus - a 5. ${ }^{\mathrm{a}}$ feira imediatamente a seguir ao domingo da Trindade - um Império para o qual contribuíam todas as casas do lugar. Hoje em dia, parte desta estrutura, já muito debilitada, entrou em declínio e realizam-se apenas dois Impérios, um no domingo de Pentecostes, outro no domingo da Trindade, cada um ligado a seu ponto. O modo como inicialmente a organização dos festejos nos Fetais foi decalcada do sistema geral prevalecente na freguesia deve ser sublinhado. Tudo se passa como se, para afirmar a sua autonomia, os habitantes do lugar não considerassem suficiente a simples realização de festejos próprios. Ao mesmo tempo, há como que uma apropriação de dispositivos de natureza similar aos que subjazem à conceptualização da freguesia - a divisão em pontos. Ao fazê-lo, os habitantes dos Fetais não só reclamam uma equivalência entre o estatuto do seu lugar e o da freguesia da qual se pretendem demarcar, como, nesse movimento, põem em evidência o carácter verdadeiramente estrutural desses dispositivos, comutáveis entre si independentemente do estatuto sociológico empírico - lugar, freguesia — das unidades que a eles recorrem.

Uma confirmação suplementar do que acabámos de dizer é-nos fornecida pela organização dos festejos na freguesia da Ribeirinha, que confina, a noroeste, com a da Piedade. Esta freguesia foi criada recentemente, em 1981. Até então a Ribeirinha constituía um lugar da freguesia da Piedade, dotado entretanto de uma grande autonomia, particularmente marcada no plano religioso - o lugar constituía um curato da paróquia da Piedade - e no plano matrimonial - eram relativamente raros os casamentos entre residentes no lugar e residentes no resto da freguesia ${ }^{1}$. Foi

1 Os casamentos entre indivíduos residentes na Ribeirinha e indivíduos pertencentes aos restantes lugares da freguesia da Piedade correspondem a cerca de 5\% do total de casamentos recenseados a partir da consulta aos assentos paroquiais da Piedade. 
aliás em consequência dessa autonomia que se deu, sem incidentes de maior, a sua passagem a freguesia. Ora uma das expressões mais relevantes dessa autonomia do lugar passava não apenas pela organização de Impérios próprios, mas, mais uma vez, pela adopção em seu torno de uma divisão do lugar em três pontos, cada um dos quais tinha a seu cargo a promoção dos festejos no domingo e na 2. ${ }^{\text {a }}$ feira de Pentecostes e no domingo da Trindade.

Regressemos entretanto aos Impérios dos Fetais. Tal como no caso que abordámos na primeira parte deste estudo - cf. pp. 121 a 127 do Capítulo 5 - - também aqui, é a partir da condição periférica do lugar no sistema sócial local que é possível interpretar os factos que passámos atrás em revista. Situado geograficamente num dos extremos da freguesia, recorrentemente apresentado como o lugar mais pobre, os Fetais são também o lugar onde é mais elevada a taxa de endogamia de lugar: 53\% contra a média de $30 \%$ prevalecente nos restantes lugares. A rivalidade entre o lugar e o resto da freguesia é também muito forte. É nesse quadro que é aliás possível analisar o incidente que esteve na origem da exclusão dos Fetais do sistema de pontos: as acusações e suspeições mútuas opunham os Fetais ao resto da freguesia e tinham nessa rivalidade - conduzida então ao limite da violência física - o seu pano de fundo. Embora atenuada pela passagem dos anos, esta rivalidade mantem-se na actualidade. Há ainda quem trate os dos Fetais por «canalha dos Fetais» e por causa deste epíteto, teria mesmo ocorrido, há cerca de 30 anos, um segundo incidente com consequências mortais entre um grupo de habitantes do lugar e um grupo de habitantes do resto da freguesia. Finalmente, há um terceiro plano em que a condição periférica dos Fetais se afirma: esse plano é o religioso. De facto, em contraste com o catolicismo predominante no conjunto da freguesia, cerca de $50 \%$ da população dos Fetais - isto é, à volta de trinta a trinta e cinco casas está filiada numa das três igrejas protestantes com implantação no lugar: Testemunhas de Jeová, Adventistas do Sétimo Dia e Novas da Alegria. Intervindo num meio tradicionalmente tão católico como os Açores, esta situação é reveladora do grau de periferização do lugar em relação ao meio social envolvente.

E justamente neste quadro que é possível entender o estatuto também ele periférico dos Fetais em relação às Festas do Espírito Santo na Piedade. Por seu intermédio, somos de novo confrontados com a aptidão - que havíamos já surpreendido em Santo Antão - das Festas do Espírito Santo para operarem como um instrumento de radical reformulação de identidades sociológicas relativas. Aparecendo ligadas, em Santo Antão, à autonomização da freguesia, as Festas do Espírito Santo actuam neste caso como um elemento essencial de um processo através do qual um lugar procura reestruturar de forma profunda o seu estatuto sociológico. 
As Coroações e Impérios na Piedade permitem-nos pois reencontrar, formulados embora de uma forma diferente, alguns dos temas centrais que havíamos começado por isolar em torno dos Impérios de Santa Bárbara e que reencontrámos a propósito das Festas do Espírito Santo em Santo Antão. Tal como nestas duas freguesias, as Coroações e Impérios da Piedade definem-se também como um ritual que, a par de uma importante vertente religiosa, se caracteriza pela sua ligação a ideias de reiteração das relação sociais. Começando por operar num âmbito mais restrito - ligado às esferas de sociabilidade de cada um dos mordomos - essas ideias estendem-se também num segundo e decisivo momento às instâncias centrais sobre as quais se funda a organização social local.

Tal como em Santa Bárbara e em Santo Antão, também na Piedade, estas características sociológicas das Festas do Espírito Santo devem ser entendidas à luz do vínculo entre ritual, relações sociais e tempo. E tal como nessas duas freguesias, os festejos surgem simultaneamente associados a ideias de renascimento da natureza e de regeneração da fertilidade. Como vimos, muitas das crianças e adolescentes que integram os cortejos que rodeiam a coroação transportam consigo ramos de flores e tanto os açafates com bolos oferecidos ao Império como os carros de bois que procedem ao transporte do vinho são também ornamentados com decorações florais.

Simultaneamente, deve ser de novo sublinhada a importância do código etário na estrutura dos festejos. Para além da coroação incidir - como em Santo Antão - sobre duas crianças ou adolescentes, os cortejos que a rodeiam reservam igualmente, como vimos, um papel importante a crianças. A preferência por crianças ou adolescentes do sexo feminino é também muito marcada e por seu intermédio somos de novo confrontados com a exploração das potencialidades significantes da figura feminina e com a sua aptidão em expressar ideias de renovação. 
PARTE III

SÃO MIGUEL: ROMARIAS QUARESMAIS E FESTAS DO ESPÍRITO SANTO 
O vínculo entre Festas do Espirito Santo, estrutura social e tempo tem sido recorrentemente sublinhado no decurso deste estudo.

Uma das expressões desse vínculo - conforme tivemos ocasião de sublinhar no Capítulo consagrado ao «Tempo dos Impérios» - deriva da colocação das Festas do Espírito Santo no interior do ciclo cerimonial anual. Sobrevindo na sequência dos «ciclos» do Carnaval e da Quaresma, as Festas do Espírito Santo ligam-se a ideias de reiteração cíclica das relações sociais que podem ser interpretadas por referência à latência social característica da Quaresma. Entre este ciclo cerimonial e as Festas do Espírito Santo é detectável, em consequência, um conjunto de oposições e complementariedades que, começando por operar no plano sociológico, se estende ainda a outros registos simbólicos.

Este contraste entre Festas do Espírito Santo e Quaresma recebe, na ilha de Sao Miguel, um significado acrescido, resultante da articulação da Quaresma com as chamadas Romarias Quaresmais. Específicas de São Miguel - onde são conhecidas mais usualmente pela expressão abreviada de Romaria -, as Romarias Quaresmais conferem de facto uma expressão particularmente enfática às ideias de latência social e de morte, por referência às quais podem ser entendidas as características sociológicas que as Festas do Espírito Santo apresentam.

\section{II}

Com origens ainda hoje sujeitas a controvérsia ${ }^{1}$, as Romarias Quaresmais podem ser genericamente apresentadas como uma peregrinação visando a prá-

${ }^{1}$ A tese mais divulgada acerca das origens das Romarias fá-las remontar às crises sísmicas que atingiram a ilha de São Miguel em 1522 e 1563. Esta tese foi detalhadamente defendida 
tica intensiva da oração e da penitência. Decorrendo numa das semanas da Quaresma, essa peregrinação centra-se sobre a totalidade das igrejas e ermidas da ilha de São Miguel consagradas a Nossa Senhora - as chamadas Casas de Nossa Senhora —, às quais se acrescentam ainda um grande número de igrejas e ermidas colocadas sob outras invocações. No total, são visitados no decurso do ritual cerca de cem lugares de culto, distribuídos pelo conjunto das cinquenta e oito freguesias de São Miguel (cf. mapa 19). Dadas as características predominantemente litorais do povoamento da ilha, o itinerário da Romaria tem uma configuração circular, devendo fazer-se sempre no sentido dos ponteiros do relógio.

A participação no ritual tem lugar no quadro de grupos constituídos expressamente para o efeito, os ranchos de romeiros. Os romeiros envergam um traje próprio, constituído por um xaile caído sobre os ombros e um lenço que, sendo mais correntemente atado ao pescoço, pode ser também usado à cabeça. Além disso, todos os romeiros se fazem acompanhar de um bordão e de um terço, e ainda de um saco de pano, ou sovadeira, levado às costas e onde são transportados alguns alimentos e, eventualmente, uma muda de roupa.

As motivações que conduzem à participação na Romaria são de duas ordens. Para um número importante de romeiros o ritual tende a configurar-se como uma devoção genérica e regular. A participação na Romaria reserva nestes casos um importante papel às ideias de perdão e reconciliação com a divindade e de regeneração espiritual periódica a que a Quaresma confere particular relevo. Em segundo lugar, as Romarias constituem, no quadro das formas de religiosidade popular dominantes em São Miguel, um meio de satisfação de promessas individuais, geralmente relacionadas com circunstâncias graves da vida - doença, acidentes.

Os ranchos de romeiros constituem-se por freguesia e possuem uma dimensão variável, de acordo com a maior ou menor expressão local do culto e em função do número de pessoas que, em cada ano, pretendem cumprir o ritual.

por Ernesto Ferreira (1959), tendo sido posteriormente retomada por outros autores. De acordo com ela, as Romarias seriam o resultado da institucionalização de manifestações espontâneas de piedade popular no decurso dessas crises sísmicas, tal como elas são descritas nas crónicas de Gaspar Frutuoso e Frei Agostinho de Montalverne. Embora incorporada na estrutura de fundamentação do ritual, esta «narrativa das origens» apoia-se entretanto em elementos que não são completamente seguros, impondo-se por isso uma investigação mais aprofundada nessa área.

A apresentação etnográfica das Romarias Quaresmais a que procedo em seguida baseiase, como ficou indicado na "Apresentação», numa recolha efectuada junto do rancho de Ponta Garça, complementada posteriormente com recolhas mais breves de informação junto de outros ranchos. Procurei reter os aspectos carcterizadores centrais do ritual, com sacrifício de aspectos de detalhe susceptíveis de enfraquecer a linha central de argumentação do Capítulo. Para uma apresentação etnográfica mais detalhada do ritual, cf. Leal, 1989. Entre a bibliografia consagrada às Romarias Quaresmais, veja-se também: Ataíde, 1920, 781-782; Câmara, 1984, 77-

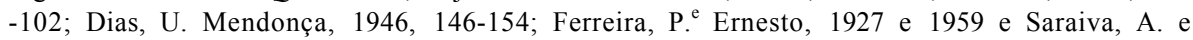
Dias, T., 1987. 


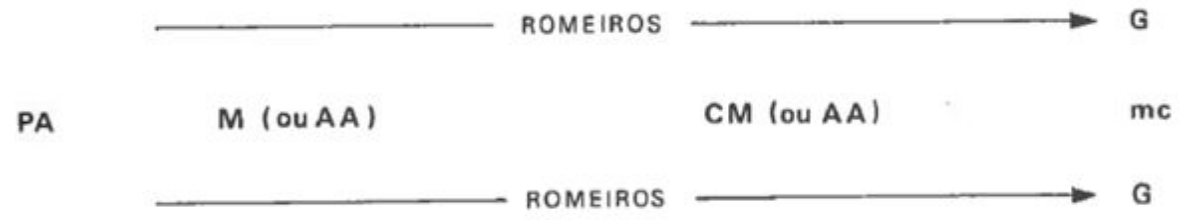

FIGURA 10

Organização dos Ranchos de Romeiros

Legenda: $\mathrm{G}$ - guias; mc - menino da cruz; CM - contra-mestre; $\mathrm{M}$ - mestre: AA — alembrador das almas; PA - procurador das almas.

Se, no decurso dos anos 60 e 70 certos ranchos chegaram a integrar duzentos romeiros, a dimensão da maioria dos ranchos oscila actualmente entre os vinte e os cem romeiros. Os ranchos possuem uma estrutura interna própria, caracterizada pela sua autonomia em relação à hierarquia eclesiástica. A direcção do ritual está a cargo do mestre, que é geralmente assistido por um contramestre. Cada rancho integra também dois guias, a quem compete a sua condução ao longo do itinerário tradicionalmente estabelecido. A existência de um ou dois dispenseiros está igualmente prevista, relacionando-se as suas atribuições principais com o aprovisionamento alimentar do rancho: só eles estão autorizados a abandonar o rancho para adquirirem os produtos alimentares que cada romeiro lhes solicite. Finalmente, integram ainda o rancho o menino da cruz - encarregue do transporte de uma pequena cruz - e o alembrador e o procurador das almas cujas funções, de ordem cerimonial, se ligam à oração. O rancho, quando em marcha, adopta uma formação convencional constituída por duas alas de romeiros caminhando a par e separados entre si cerca de 2 metros. Como se pode verificar na figura 10, alguns dos detentores dos cargos atrás referidos ocupam no rancho um lugar tradicionalmente definido.

Tendo lugar numa das semanas da Quaresma - variável de rancho para rancho, mas que, para cada rancho é sempre a mesma de ano para ano o ritual inicia-se a um sábado ou a um domingo e o seu termo ocorre no domingo seguinte. O percurso realizado pelo rancho ao longo da Romaria tem uma extensão aproximada de $200 \mathrm{~km}$. e estrutura-se em etapas diárias de cerca de 25/30 kms. A marcha inicia-se muito cedo, por volta das $4 / 5$ horas da madrugada e termina cerca das 20 horas da noite. No quadro de cada etapa, está previsto um certo número de paragens - que têm geralmente lugar em sítios retirados - tanto para curtas pausas de descanso, como para as refeições. As unidades de referência da caminhada são as freguesias de pernoita: um certo número de freguesias tradicionalmente definidas, variáveis de rancho para rancho, onde os romeiros passam a noite (cf. a este propósito, o mapa 19). No passado, essas pernoitas tinham lugar em cafuas 


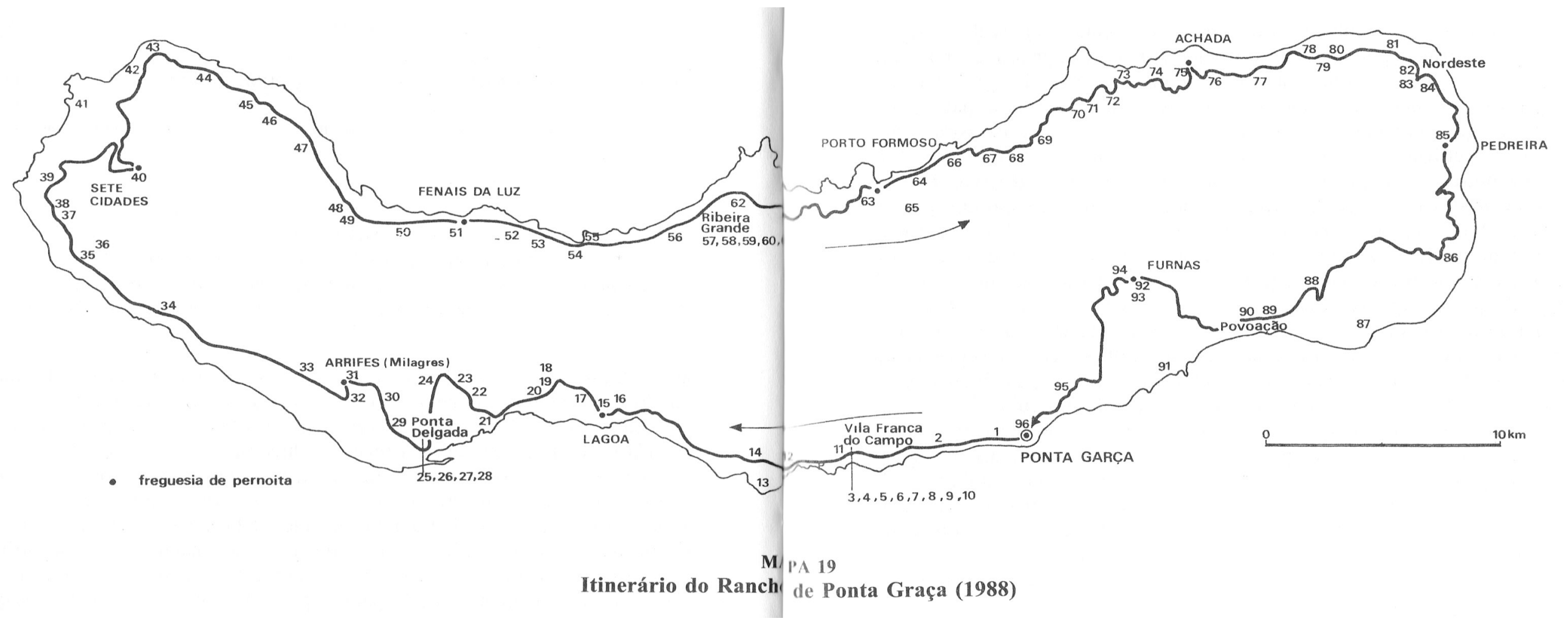

1. Senhora da Vida (Ponta Garça). 2. Bom Jesus Menino (Ribeira das Tainhas). 3. Senhora da Paz (Vila Franca do Campo). 4. Santo André (Vila Franca do Campo). 5. Mãe de Deus (Vila Franca do Campo). 6. São Miguel (Vila Franca do Campo). 7. Bom Jesus da Pedra (Vila Franca do Campo). 8. Senhora da Natividade (Vila Franca do Campo). 9. São Pedro (Vila Franca do Campo). 10. Senhora de Fátima (Vil Franca do Campo). 11. São Lázaro (Agua de Alto). 12. São José (Ribeira Chã). 13. Senhora das Dores (Águ Pau). 14. Senhora dos Anjos (Agua Pau). 15. Santa Cruz (Lagoa). 16. Senhora do Rosário (Lagoa). 17. Senhora das Necessidades (Atalhada). 18. Senhora do Livramento (Livramento). 19. Senhora do Carmo (Livramento). 20. Senhora da Glória (Livramento). 21. São Roque (São Roque). 22. São João de Deus (Fajă de Baixo). 23. Senhora dos Anjos (Fajã de Baixo). 24. Senhora da Oliveira (Fajã de Cima). 25. São Sebastião (Ponta Delgada/matriz). 26. São José (Ponta Delgada). 27. Senhor Santo Cristo (Ponta Delgada). 28. Senho Santo Cristo (Seminátio/Ponta Delgada). 29. Senhora da Conceição (Casa de Saúde/Ponta Delgada). 30. Senhor da Piedade (Arrifes/Piedade). 31. Senhora dos Milagres (Arrifes/Milagres). 32. Senhora da Saúd (Arrifes/Milagres). 33. Senhora da Ajuda (Covoada). 34. Santa Luzia (Feteiras). 35. Senhora das Candeia (Candelária). 36. Senhora do Socorro (Candelária). 37. São Sebastião (Ginetes). 38. Senhora de Fátima (Ginetes). 39. Sagrada Familia (Varzea). 40. São Nicolau (Sete Cidades). 41. Senhora da Conceição (Mosteiros). 42. Senhora da Conceição (Pilar da Bretanha). 43. Senhora do Pilar (Pilar da Bretanha). 44. Senhora da Ajud (Ajuda da Bretanha). 45. Senhora dos Remédios (Ajuda da Bretanha). 46. Santa Bárbara (Santa Bárbara). 47. Santo António (Santo António). 48 Senhora da Apresentação (Capelas). 49. Senhora do Rosário (Capelas)

ou palheiros, situados nas imediações das povoações. Actualmente, porém, os ranchos beneficiam da hospitalidade dos moradores. Nas casas onde pernoitam, os romeiros tomam a refeição da noite e podem ainda proceder a cuidados de higiene, embora muito sumários. De facto, durante todo o período de duração da Romaria, os cuidados de higiene dos romeiros são redu-
50. Senhora da Conceição (São Vicente). 51. Senhora da Luz (Fenaes da Luz). 52. Senhora da Boa Viagem (Calhetas). 53. Senhora das Mercês (Calhetas). 54. Senhora do Rosário (Rabo de Peixe). 55. Jesus Crucificado (Rabo de Peixe). 56. São Pedro (Ribeira Seca). 57. Senhora do Guadalupe (Ribeira Grande). 58. Senhora da Conceição (Ribeira Grande). 59. Senhor dos Passos (Ribeira Grande). 60. Senhora da Estrela (Ribeira Grande/matriz). 61. Senhora de Fátima (Ribeira Grande). 62. São Salvador do Mundo (Ribeirinha). 63. Senhora da Graça (Porto Formoso). 64. São Brás (São Brás). 65. Senhora do Resgate (Gorreana). 66. Divino Espírito Santo (Maia). 67. Senhora das Dores (Lombinha da Maia). 68. Senhora do Rosário (Lomba da Maia). 69. Senhora da Aflição (Ribeira Funda). 70. Reis Magos (Fenaes da Ajuda). 71. Senhora da Ajuda (Fenaes da Ajuda). 72. São Pedro (Lomba de São Pedro). 73. São José (Salga). 74. Senhora do Rosário (Algarvia), 78. Santo António (Santo António do Nordestinho), 79. São Pedro (São Pedro do Nordestinho). 80. Senhor do Pranto (São Pedro do Nordestinho) 81. Senhora da Concĩão (Lo do Rosário (Nordeste). 83. São Jorge (Nordeste). 84. Senhora da Nazaré (Nordeste). 85. Senhora da Luz do Rosario (Nordeste). 83. São Jorge (Nordestera da Luz (Pedreira do Nordeste). 86. Senhora da Penha de França (Agua Retorta). 87. Senhora da Graça (Faial da
Terra). 88. Senhora dos Remédios (Povoacão). 89. Mãe de deus (Povoacão/matriz), 90. Senhora do Rosário Terra). 88. Senhora dos Remédios (Povoação). 89. Mãe de deus (Povoação/matriz). 90. Senhora do Rosário Senhora da Vitória (Furnas), 95. Senhora das Mercês (Ponta Garça). 96. Senhora da Piedade (Ponta Garça).

(Nota: as ermidas e igrejas em «bold» correspondem às que o rancho de Ponta Garça «saúda de longe»)

zidos ao mínimo, não apenas em resultado das circunstâncias objectivas que rodeiam o ritual, mas também como parte integrante dos usos e costumes com que ele se articula. Desses usos e costumes, merece particular menção a interdição de fazer a barba no decurso da Romaria, ainda hoje observável com notável uniformidade. 
As características penitenciais da Romaria assentam, antes de mais, na dureza do próprio percurso realizado pelos ranchos, expressa quer na sua extensão global, quer no ritmo diário da marcha. A este quadro geral somam-se muitas vezes condicionalismos específicos. Assim, embora a maior parte do percurso seja actualmente feito por estrada, em muitos casos, para cortar caminho, são utilizados atalhos secundários, que tornam a marcha mais difícil. É por outro lado frequente que a Romaria se desenrole debaixo de condições meteorológicas adversas, características da altura do ano em que ela se realiza. A marcha do rancho não deve ser interrompida sob nenhum pretexto e pode muitas vezes realizar-se dias a fio debaixo de chuva intensa e contínua. Estes factores contribuem para conferir uma dureza suplementar à caminhada que o grupo deve realizar. As marcas dessa dureza, perdida a frescura dos primeiros dias, não tardam em aparecer. Além do cansaço geral, começa a manifestar-se todo o tipo de sequelas: bolhas e calos nos pés, dores musculares, etc... Muitos romeiros consideram-nas parte da penitência e recusam-se a efectuar qualquer tipo de tratamento. A par das dificuldades da caminhada, a penitência assenta noutros dispositivos, relacionados designadamente com a alimentação. Esta, se exceptuarmos a refeição da noite, mais abundante e oferecida pelos donos da casa onde o romeiro pernoita, é em geral algo exígua. Em certos casos a alimentação adquire um mais acentuado valor penitencial. É o que se passa com os romeiros que, em resultado de promessa, participam na Romaria a pão e água. A privação alimentar extrema a que se submetem, reforçando substancialmente as dificuldades ligadas ao ritual, transforma a caminhada num verdadeiro sacrifício.

No passado, as condições precárias em que decorriam as pernoitas acentuavam também este quadro de dificuldades. E, mesmo hoje em dia, existe sempre o risco, sobretudo no caso de ranchos maiores, de a hospitalidade dos moradores das freguesias de pernoita ser insuficiente para arrumar a totalidade do rancho, podendo os romeiros remanescentes terem de dormir numa situação menos confortável, em qualquer recinto de circunstância.

Quanto à oração, ela centra-se, em primeiro lugar, em paragens regulares em cada uma das igrejas e ermidas que a Romaria deve visitar. Essas paragens têm uma duração variável — entre 15 a 30 minutos — de acordo com vários factores e organizam-se segundo um padrão relativamente complexo, algo diferenciado de rancho para rancho. A par de um certo número de orações retirados da devoção geral católica - sequências de «Pais Nossos»e «Ave Marias», o «Credo», outras orações mais curtas —, o seu núcleo mais importante é constituído por um conjunto de orações e cânticos de características tradicionais mais ou menos marcadas, onde avultam temas eminentemente quaresmais ${ }^{1}$.

\footnotetext{
$432-435$.

${ }^{1}$ Para uma apresentação mais detalhada dos textos destas orações e cânticos, cf. Leal, 1989,
} 
Paralelamente à oração junto às igrejas e ermidas, o conjunto do percurso da Romaria, sobretudo nos ranchos mais rigorosos, deve ser feito integralmente a rezar. Em comparação com a oração junto às igrejas e ermidas, esta segunda grande modalidade da oração apresenta entretanto, de rancho para rancho, uma estrutura mais uniforme. Nela avulta, como figura central, a «Ave Maria dos Romeiros», um cântico de características tradicionais construído a partir da «Ave Maria». Cântico por excelência da Romaria, a «Ave Maria dos Romeiros» é também o seu verdadeiro «emblema» acústico. As suas características de coral colectivo, severo e plangente - em cuja linha melódica Bettencourt da Câmara (1984: 95) detectou a influência do cantochão, combinada com elementos de natureza popular - transmitem de forma particularmente incisiva as principais linhas de força do ritual. Entoada quer à aproximação das igrejas e ermidas, quer no termo das sequências de oração nelas centradas, a "Ave Maria dos Romeiros» é ainda de norma sempre que o rancho atravessa povoações ou lugares habitados. Além das suas características genéricas de cântico religioso em louvor de Nossa Senhora, a «Ave Maria dos Romeiros» articula-se com formas específicas de oração. A espaços, o cântico é interrompido por um "pregão» - ou salva — entoado em tom arrastado pelo alembrador das almas ou pelo mestre. Esse «pregão» é usualmente conhecido através das expressões alembrar as almas ou bradar às almas, e por seu intermédio, o alembrador das almas (ou o mestre) solicita, quer ao rancho, quer às pessoas que assistem à sua passagem, que rezem um determinado número de orações - geralmente um «Pai Nosso» e uma «Ave Maria» - por intenções que são especificadas no próprio «pregão».

Ao lado da «Ave Maria dos Romeiros», a oração durante a marcha reserva um papel importante à recitação do terço, que é de norma sempre que o rancho caminha em descampados. A recitação do terço pode ser colectiva e em voz alta ou individual e em silêncio. Cada uma das duas modalidades corresponde a objectivos distintos. Assim, os terços rezados individualmente e em silêncio - que no cômputo global da Romaria podem subir a cerca de quarenta - ligam-se a uma componente mais pessoal da oração de cada romeiro e destinam-se sobretudo às suas intenções individuais. Quanto aos terços rezados em voz alta - cujo quantitativo se eleva também a cerca de quarenta destinam-se fundamentalmente a satisfazer pedidos expressamente feitos ao rancho por pessoas que lhe são exteriores. Nesses pedidos, as pessoas solicitam ao rancho que reze, por intenções que elas especificam, um determinado número de orações - geralmente um «Pai Nosso» e uma «Ave Maria». Ao solicitarem essas orações, esses indivíduos comprometem-se em troca a rezar, em função do seu pedido, um número de orações equivalente ao número de romeiros do rancho mais três, correspondente às três pessoas da Santíssima Trindade ${ }^{1}$. A reco-

\footnotetext{
${ }^{1}$ Esta tradição possui a sua justificação no facto de as Três Pessoas da Santíssima Trindade serem consideradas como parte integrante do rancho.
} 
lha desses pedidos constitui a função exclusiva do procurador das almas, que informa também as pessoas que se lhe dirigem do número de romeiros que o rancho integra.

A importância destas formas de trocas de oração deve ser sublinhada. Por seu intermédio, a Romaria projecta-se para fora do quadro estrito em que começa por situar-se e tende a vincular a si o conjunto da sociedade. Continuamente atravessadas, ao longo das sete semanas da Quaresma, por sucessivos ranchos de romeiros, os habitantes das diferentes freguesias da ilha são no fundo convidados a associar-se ao espírito de penitência e oração que os ranchos encarnam.

Reservando um papel fundamental a esses dois temas centrais da religiosidade quaresmal que são a penitência e a oração, as Romarias ecoam também de forma particularmente enfática as ideias de latência social e de morte características deste período do ciclo cerimonial anual.

As ideias de latência social expressam-se em primeiro lugar na renúncia à vida social inscrita na Romaria. A consagração exclusiva à penitência e à oração não significa apenas um corte com as ocupações quotidianas mas exige também uma ruptura momentânea com a rede de relações sociais.

Essa ruptura começa por intervir em relação aos laços familiares e de parentesco e expressa-se no momentâneo corte, durante todo o período de duração da Romaria, com essas esferas fundamentais do relacionamento social de cada indivíduo. Essa ruptura é vivida de uma forma particularmente enfática pelos protagonistas do ritual. Assim, é bastante usual que, na véspera da partida do rancho, muitos romeiros se desloquem propositadamente a casa de alguns parentes mais chegados, para apresentar despedidas. A partida e a chegada do rancho à freguesia de origem, por outro lado, tendem a confundir-se com ocasiões, fortemente marcadas de um ponto de vista emocional, de separação e reagregação na unidade doméstica. A partida, as famílias, depois de assistirem, em conjunto com os romeiros, à missa celebrada na igreja paroquial, acompanham o rancho até aos limites da freguesia e, depois da primeira refeição do rancho, têm lugar as despedidas formais. A chegada do rancho, por seu turno, os romeiros são aguardados pelas respectivas famílias, que tomam também a refeição com eles, e que, depois, os acompanham na parte final do percurso, assistindo igualmente à missa que põe termo à Romaria.

Paralelamente ao corte com as relações familiares e de parentesco, as Romarias Quaresmais pressupõem também uma momentânea ruptura com a freguesia, unidade central da vida social nos Açores e poderoso mecanismo de definição da identidade colectiva. Esta ruptura deriva do modo como a 
Romaria projecta os ranchos para o exterior das suas freguesias de origem. Fazendo-o, a Romaria configura-se como um ritual envolvendo uma marcada componente de «nomadização» e exterioridade em relação a esse espaço social. Essa condição de exterioridade é enfatizada em certos detalhes do ritual. Era o que se passava, há alguns anos, quando as pernoitas tinham lugar em cafuas ou palheiros, geralmente situados nas imediações das povoações, vincando a condição de exterioridade do rancho. Apesar de hoje em dia a situação se ter modificado e de os ranchos beneficiarem, nas freguesias de pernoita, da hospitalidade dos respectivos moradores, essa hospitalidade aparece entretanto rodeada de sinais que revelam a exterioridade do rancho. Assim, por exemplo, alguns dos dispositivos que rodeiam as pernoitas impõem aos romeiros uma atitude de reserva em relação aos seus hospedeiros: eles são supostos responder de forma breve às questões que lhe forem colocadas, não devem assumir a iniciativa do diálogo, retiram-se o mais cedo possível depois da refeição, etc...

Intervindo num primeiro momento em relação a unidades sociais precisas, a ruptura com o quadro social inscrita na Romaria estende-se por fim à vida social no seu conjunto e às suas expressões mais genéricas. No decurso da Romaria, as relações do rancho com o exterior vêem-se de facto restringidas ao máximo. Os romeiros não devem, sob nenhum pretexto, abandonar o rancho, sobretudo durante as pausas para descanso ou refeições - usualmente em lugares retirados — ou durante as pernoitas. No decurso destas, como vimos, são-lhes impostas formas de reserva em relação aos seus hospedeiros que acentuam também o seu divórcio com o mundo exterior. E-lhes ainda interdito cumprimentar ou visitar qualquer parente ou amigo nas freguesias percorridas pelo rancho. As compras necessárias ao rancho, por fim, são da responsabilidade exclusiva dos dispenseiros, impedindo a multiplicação de contactos individuais com o mundo exterior.

Começando por assentar nestas formas de ruptura em relação à estrutura social, as ideias de margem e latência sociais presentes nas Romarias Quaresmais expressam-se ainda na sua articulação com um universo sociológico caracterizado por valores muito claros de «communitas». Proposta por V. Turner (cf. Turner, 1969a; 1969b e 1974), esta expressão procura designar o tipo de relacionamento social prevelecente em certos rituais marcados por ideias muito fortes de margem ou liminaridade: ritos de passagem, certo tipo de cerimónias cíclicas, peregrinações, etc... Nesses rituais, um conjunto muito diversificado de valores - entre os quais Turner inclui a camaradagem e o igualitarismo, a indiferenciação e a homogeneidade sociais, a submissão e a renúncia ao individualismo ${ }^{1}$ - funcionariam por oposição às regras que estru-

\footnotetext{
${ }^{1}$ Uma apresentação mais detalhada do conjunto de valores a que se subordina a ideia de «communitas» pode encontrar-se em Turner, 1969a: 106-107.
} 
turam a vida social corrente - a «societas» — contribuindo para sublinhar de forma particularmente enfática ideias de margem ou liminaridade em relação à sociedade ${ }^{1}$.

E um quadro similar que podemos reencontrar nas Romarias. Retirando o indivíduo da estrutura social, estas situam-no simultaneamente numa «communitas» onde se suspendem momentaneamente alguns dos grandes traços caracterizadores da vida social corrente — os conflitos, a diferenciação social, o individualismo - , substituindo-os pelos valores exactamente opostos - a fraternidade, a indiferenciação e a homogeneidade sociais, o «holismo» ${ }^{2}$.

Os valores da fraternidade são explicitamente introduzidos no ritual pela forma de tratamento mútuo por irmão que vigora entre os peregrinos; e pelo abraço, que constitui a forma habitual de saudação no interior do rancho. Simultaneamente, é colocada grande ênfase na harmonia que deve caracterizar as relações entre romeiros. "Uma grande família», "uma união muito forte», «a gente aqui somos mesmo como irmãos», são algumas das frases que ouvimos muitas vezes a esse respeito. O ritual prevê mesmo que, caso se integrem no mesmo rancho dois indivíduos em situação de conflito, tenha lugar um pequeno ritual de reconciliação entre eles, descrito da seguinte forma no Regulamento eclesiástico da Romaria: «se acontecer de nalguns ranchos se encontrarem pessoas inimigas ou rivais, o Mestre, no primeiro escampado, tocará a campainha para o rancho e chamando os desavindos, à vista de toda a comunidade, convida-os a abraçarem-se cordialmente, fá-los caminhar lado a lado durante a viagem e dormir na mesma casa, para que a amizade volte a reinar entre eles» (Regulamento..., 1962: 41).

Quanto às ideias de indiferenciação e homogeneidade social, elas começam por expressar-se no modo como a Romaria apaga os critérios estatutários, diferenciadores, que forjam usualmente a identidade social. Os ranchos apresentam de facto, no respeitante à sua composição, uma certa heterogeneidade

\footnotetext{
${ }^{1}$ Alguns estudos recentes têm procurado problematizar a equação estabelecida por Turner entre peregrinação e «communitas»: cf. em particular Eade e Sallnow, 1991. Na introdução, os autores sublinham a maneira como os estudos por eles recolhidos vão no sentido do reconhecimento que a peregrinação «é, sobretudo, uma arena para discursos religiosos e seculares concorrentes, para a cooptação oficial ou a recuperação não oficial de significados religiosos, para o conflito entre ortodoxias, seitas e grupos confessionais, para tentativas de consenso e communitas $e$ para contra-movimentos no sentido da separação e da divisão» (Eade e Sallnow, 1991: 2). Esta pluralidade de discursos pode encontrar-se em torno das Romarias. A igreja, a intelectualidade local e os peregrinos avaliam diferentemente o significado do culto. Mas esse facto não invalida que, do ponto de vista dos peregrinos, a Romaria não corresponda em grande medida a uma experiência similar àquela que Turner procurou descrever através do conceito de «communitas».

${ }^{2}$ Esta expressão é aqui utilizada no sentido mais corrente que recebe em ciências sociais. Cf., a este respeito a obra de Dumont, em particular, 1966: 13-35.
} 
socio-profissional e etária ${ }^{1}$. É justamente essa heterogeneidade que é suprimida no decurso do ritual. A forma de tratamento mútuo por irmão estabelece uma equivalência entre todos os romeiros. Por outro lado, as atitudes exigidas entre romeiros impõem a parentes e amigos formas de relação que dissolvem uma proximidade de primeiro grau, baseada nas linguagens do parentesco e da amizade, e a reconvertem numa proximidade de segundo grau, definida exclusivamente pela pertença ao rancho. É por exemplo frequente que, no mesmo rancho, se encontrem membros da mesma unidade doméstica, uma vez que, sobretudo entre o seu núcleo mais estável, a Romaria se tende a configurar como uma tradição de características familiares, que se transmite de pais para filhos. Nesses casos, existe uma preocupação clara de quebrar, designadamente através da atitude prevalecente durante as refeições, o carácter privilegiado dessas relações. Da mesma forma, no modo como alguns mestres distribuem os romeiros para as pernoitas - em grupos de dois ou mais romeiros, de acordo com as disponibilidades de cada casa - os critérios seguidos reafirmam que qualquer romeiro é potencialmente parceiro de qualquer outro romeiro.

Um terceiro aspecto relevante do universo sociológico proposto pela Romaria é, por fim, a renúncia ao individualismo e a sua substituição por um quadro social caracterizado pelo «holismo». Este quadro social começa por resultar, antes do mais, da fraternidade e da indiferenciação social prevalecentes na Romaria. Assim, a harmonia social faz-se acompanhar de uma renúncia total às prerrogativas e à expressão do individualismo, como aliás é perfeitamente claro no ritual de reconciliação que referimos atrás. E necessário que, pelo menos momentaneamente, cada indivíduo ponha de lado não apenas aquilo que, separando-o de um outro, o investe de autonomia, mas que renuncie também, para retomarmos a expressão que nos foi reproduzida a esse respeito, ao seu orgulho. Por outro lado, destituído dos atributos que o diferenciam, cada romeiro vê-se simultaneamente desprovido dos aspectos estritamente individuais da sua identidade.

A natureza «holista» da Romaria assenta também no papel que no ritual têm os valores da disciplina e da «humildade». A disciplina constitui um dos aspectos centrais do funcionamento interno de cada rancho e expressa-se num conjunto de normas que dizem respeito, tanto às relações do rancho com o exterior, como à conduta interna a observar no seu interior. Esta disciplina não é entretanto concebida como uma imposição: trata-se, pelo contrário, de uma submissão espontânea e voluntária do indivíduo ao grupo.

${ }^{1}$ Estes dois traços ressaltam claramente dos dados publicados em Saraiva, A. e Dias, T., 1987, 30-31. Numa amostragem de cerca de cento e vinte romeiros, $18 \%$ tinham entre 9 a 16 anos, $38 \%$ entre 17 a $25,27 \%$ entre 26 a $35,13 \%$ entre 36 a 60 e $3 \%$ mais de 60 anos. Quanto aos principais grupos profissionais, os camponeses e os agricultores representavam $31 \%$ do total, os operários da construção civil $23 \%$, os empregados de serviços $14 \%$, os estudantes $13 \%$, os pescadores $7 \%$, correspondendo os restantes $13 \%$ a profissões várias. 
Quanto à «humildade», além de expressões mais genéricas, transparece de forma particularmente clara na obediência completa ao mestre. Este é não só objecto de uma forma de saudação particularmente significativa desse ponto de vista - o beija-mão - como as suas decisões, quaisquer que sejam, devem ser sempre acatadas sem reservas. Mais uma vez, é à luz das características «holistas» do quadro social da Romaria que este aspecto deve ser compreendido: o que está em causa não é a figura individual do mestre mas o modo como ele encarna no fundo a própria unidade do rancho. Submetendo-se-lhe, cada romeiro torna claro que a lógica do grupo se sobrepõe por completo à lógica individual.

Isto é, cortado do mundo social exterior, colocando-se à sua margem, o rancho deixa-se simultaneamente ver como um universo sociológico onde se suspendem momentaneamente alguns dos traços centrais da vida social: os conflitos, as diferenças de estatuto e dignidade, o individualismo. Contribuindo para enfatizar as ideias de margem e latência sociais inscritas na Romaria, este contraste entre o ritual e a vida social corrente é de resto vigorosamente sublinhado pelos próprios romeiros: «é um tempo diferente, a gente aqui somos como irmãos, mas em chegando lá fora, vêm as reichas e os ódios»; «durante uma semana é como uma família, até mais unida que a verdadeira, aquela que deixámos para trás»; etc... Para muitos romeiros, esta singular experiência sociológica constitui mesmo um dos aspectos determinantes do ritual.

\section{IV}

Caracterizando-se pela forma particularmente enfática como trabalham as ideias de latência social próprias da Quaresma, as Romarias Quaresmais podem ser vantajosamente contrapostas a alguns dos aspectos que caracterizam, inversamente, o trabalho de reiteração das relações sociais a que se entregam as Festas do Espírito Santo.

Assim, ao relevo que as Romarias colocam na ruptura com a rede de relações sociais opõe-se o acento que, inversamente, as Festas do Espírito Santo dão à reconstituição minuciosa das principais linhas de força sobre que assenta a estrutura social. Vimos que na Romaria, essa ruptura com a rede de relações sociais era dada de forma particularmente marcada a dois níveis principais: o das relações familiares e de parentesco e o da freguesia. Nas Festas do Espírito Santo, inversamente, os propósitos de recomposição das relações sociais são também particularmente explícitos a esses dois níveis. De facto, as Festas do Espírito Santo apareceram-nos ligadas quer a ideias de reiteração dos laços familiares e do parentesco - em particular no âmbito da vertente sociológica mais restrita dos festejos, ligada às figuras individuais de cada mordomo ou imperador - quer a ideias de reafirmação da freguesia 
como quadro estruturador central da vida social local. Como vimos, no auge dos festejos, os dispositivos rituais previstos, com relevo para os que se relacionam com as modalidades de circulação do alimento, concedem particular relevo à afirmação dos laços de pertença à freguesia e à reiteração da sua identidade, enquanto corpo social «unificado», face ao exterior.

$\mathrm{O}$ esforço de recomposição das relações sociais que caracteriza as Festas do Espírito Santo aparece por outro lado articulado com um processo de restauração de alguns dos traços da vida social, enquanto tecido estruturado, que pode ser também confrontado com alguns aspectos do relevo que, inversamente, as Romarias concedem a ideias de «communitas». Ao exclusivo acento nos valores da fraternidade inscritos nas Romarias, opõe-se de facto o modo como as Festas do Espírito Santo, simultaneamente a ideias de partilha e hospitalidade alimentar, fornecem também, como vimos, um terreno favorável à expressão de sentimentos de hostilidade e rivalidade. As ideias de indiferenciação e homogeneidade que as Romarias expressam, contrastam também com o acento que, inversamente, as Festas do Espírito Santo colocam na restauração da componente diferenciadora e estatutária da vida social. As modalidades de intervenção nos festejos assentam, por um lado, num conjunto de distinções sociais, baseadas na pertença a esferas sociológicas claramente demarcadas: parentesco, vizinhança, lugar, freguesia, etc... Simultaneamente, a articulação do ritual com um conjunto de símbolos e desempenhos retirados de uma linguagem de «poder» confere-lhe também uma dimensão simbólica de reposição de uma ordem social baseada na diferenciação de estatutos e na afirmação de precedências hierárquicas. Finalmente, ao «holismo» prevalecente na Romaria, opõem-se as pulsões «individualistas» a que as Festas do Espírito Santo são submetidas, resultantes do papel que na sua promoção e realização desempenham formas individuais de mordomia. De facto, como vimos, a articulação dos festejos com um elevado conjunto de despesas alimentares, suportadas em grande medida individualmente, faz com que eles sejam — objecto de pressões ligadas a reivindicações de prestígio individual.

Expressando-se de forma particularmente clara no plano sociológico, o contraste entre Romarias Quaresmais e Festas do Espírito Santo estende-se ainda a um outro registo simbólico, baseado na oposição morte/ renascimento (ou rejuvenescimento).

De facto, ao mesmo tempo que reservam um particular relevo às ideias de latência social próprias da Quaresma, as Romarias Quaresmais caracterizam-se também pelo modo como prolongam e acentuam as ideias de morte a que se liga este período do ciclo cerimonial anual.

Esta faceta do ritual exprime-se em primeiro lugar no papel central que nele ocupa a oração pelas almas do purgatório. Este traço exprime-se sobretudo no quadro da oração no decurso da marcha. Como vimos, a entoação 
colectiva da «Ave Maria dos Romeiros» é, a espaços, interrompida por um «pregão» entoado de forma arrastada, através do qual se solicita, não apenas ao rancho, mas a todos aqueles que assistem à sua passagem, um determinado número de orações. Entoados ora pelo mestre, ora pelo encomendador das almas, conhecidos pela designação genérica de bradar às almas, estes «pregões» reservam justamente um papel importante a intenções relacionadas com as almas do purgatório. De uma forma geral, essas intenções são formuladas em termos genéricos: pelo conjunto das almas do purgatório, em particular pelas mais necessitadas, ou pelas mais abandonadas, ou ainda por aquelas que não têm ninguém que reze por elas. Mas encontramos também formulações mais específicas, como as que se referem aos habitantes já falecidos das sucessivas freguesias que o rancho atravessa no seu percurso. Certos ranchos possuem mesmo orações próprias para esse efeito e rezam-nas sempre que, ao longo do percurso, passam por um cemitério. A oração no decurso da marcha reserva também, como vimos, um papel importante às orações pedidas ao rancho por pessoas que lhe são exteriores. Nesses pedidos, as intenções pelas almas do purgarório ocupam também um lugar importante. E aliás a essa luz que pode ser analisada a designação de procurador das almas dada ao romeiro que tem a seu cargo a recepção desses pedidos ${ }^{1}$.

A coerência desta ligação entre as Romarias Quaresmais e a oração pelas almas do purgatório deve ser sublinhada. Sendo a Quaresma o período do ciclo litúrgico anual consagrado à evocação da morte de Cristo, ela fornece um quadro particularmente adequado para a evocação pela sociedade dos seus próprios mortos. Os termos dessa evocação inspiram-se também no conteúdo litúrgico da Quaresma: assim como a celebração da morte de Cristo é o indispendável prelúdio à comemoração da sua ressurreição, a oração pelas almas do purgatório visa apressar a sua passagem pelo purgatório, provação preliminar à ressurreição dos mortos.

Assente na relação privilegiada com a oração pelas almas do purgatório, a ligação das Romarias Quaresmais a ideias de morte reencontra-se ainda na homologia estabelecida entre a figura do romeiro e a figura do anojado. Essa homologia assenta na interdição de fazer a barba no decurso da Romaria. Integrando-se no quadro mais geral de suspensão dos cuidados de higiene

${ }^{1}$ Esta preocupação central com o destino após a morte tem ainda outras expressões. São, por exemplo, frequentes as intenções que solicitam a protecção divina no momento da morte - «a última hora, a hora da nossa morte, para que Nosso Senhor nos assista com os sacramentos» - por vezes particularizadas em relação a pessoas que, por uma ou outra razão, se podem encontrar em perigo de morte. A actividade marítima, encarada como especialmente perigosa, é em particular objecto de várias referências explícitas. E também neste quadro que podem ser entendidos os pedidos de proteç̧ão divina em relação a «tremores de terra, fome, peste e guerra» (Câmara, 1984: 102), ou, noutras formulações, em relação a «fogo, fome, peste, guerra, mortes repentinas, perdições de almas e corpos». 
durante a semana em que tem lugar o ritual ${ }^{1}$, essa interdição inscreve nos romeiros aquela que era uma das marcas mais significativas do luto na sociedade rural tradicional. Conhecida genericamente em todo o território nacional (cf. Vasconcelos, 1925: 113 a 116), a interdição de fazer a barba durante o período mais carregado do luto reencontrava-se também em São Miguel. Mendonça Dias refere por exemplo ser «costume muito antigo (...) não se fazer a barba nos primeiros tempos de luto» (Dias, U. Mendonça, 1946: 170) e Leite de Ataíde regista também como significativa a tradição de, em sinal de "luto, os homens deixarem «crescer a barba durante algumas semanas» (Ataíde, 1947).

Recebendo, por intermédio destes dispositivos, uma ligação clara às ideias de morte genericamente inscritas no período quaresmal, as Romarias devem ser, também neste plano, confrontadas com as Festas do Espírito Santo e com a particular ênfase que estas, inversamente, colocam em ideias de renascimento e rejuvenescimento, expressas sobretudo no relevo que nos festejos possui o código etário, associado a um conjunto de desempenhos assegurados por crianças e/ou jovens.

\footnotetext{
${ }^{1}$ Conforme tive ocasião de sublinhar em Leal, 1993a, 13-14, este conjunto de dispositivos tende simultaneamente a projectar os romeiros para o mundo da natureza, por oposição ao mundo da cultura. Esta proximidade ao mundo da natureza assenta ainda noutros dispositivos. Assim, no passado, como vimos, as pernoitas tinham lugar em cafuas ou palheiros situados nas imediações das povoações, e associados portanto a um espaço situado nas margens da cultura. Ainda hoje, por outro lado, os ranchos abandonam frequentemente as estradas correntes, optando por caminhos e atalhos secundários, situados em muitos casos no interior de matos ou bosques. As próprias condições meteorológicas adversas que rodeiam muuitas vezes o trajecto são frequentemente referidas para sublinhar esta vertente de imersão na natureza inscrita no ritual.
} 
CONCLUSÕES 
Centrado nas Festas do Espírito Santo nos Açores, este estudo procurou interpretá-las de acordo com um modelo cujas principais linhas de força vale a pena evocar de uma forma sintética.

O fio condutor da análise foi fornecido pelo peso que tem no ritual um conjunto de refeições, distribuições e dádivas de natureza alimentar. Embora recorrente na etnografia portuguesa e europeia, esta associação do alimento às cerimónias cíclicas atinge nas Festas do Espírito Santo uma dimensão particularmente significativa, expressa tanto na elevada quantidade de alimentos requeridos pelos festejos como no número de casas e indivíduos abrangidos pela sua circulação. Esta componente das Festas começou por nos aparecer ligada a objectivos de carácter religioso. O dispêndio alimentar requerido pelos festejos é encarado, quer pelos seus promotores individuais - imperadores ou mordomos - quer pelo conjunto da comunidade, como uma forma de pagamento de promessas individuais e de garantia da protecção divina.

Foi entretanto em articulação com um trabalho sociológico extremamente elaborado e minucioso que a associação entre as Festas do Espírito Santo e a linguagem da dádiva alimentar nos surgiu como mais relevante. Começando por circular num âmbito restrito, ligado às relações sociais próximas de cada imperador ou mordomo - parentes, vizinhos, amigos - o alimento opera antes do mais como um instrumento de reiteração dessas relações sociais. Num segundo momento, porém, a sua esfera de circulação conhece um alargamento decisivo que faz com que as Festas do Espírito Santo se vinculem a ideias de reafirmação das instâncias mais globais sobre as quais assenta o sistema social local: o lugar e a freguesia. O seu papel de instrumento periódico de reasserção da identidade e do prestígio colectivo da freguesia, em particular, foi fortemente enfatizado, assim como o relevo que, por essa razão, têm nas Festas do Espírito Santo um conjunto de práticas marcadas pelo agonismo e rivalidade inter-freguesias. 
O sentido deste trabalho sociológico foi interpretado por referência ao vínculo existente entre as cerimónias cíclicas e as formas de conceptualização do tempo nas sociedades rurais. Associadas, em virtude da sua colocação sazonal, a ideias de renascimento da natureza e de regeneração da fertilidade, as Festas do Espírito Santo procedem simultaneamente a um trabalho de reiteração cíclica das relações sociais que deve ser entendido tanto por referência às relações de complementariedade que mantêm com os «ciclos» do Carnaval e da Quaresma - associados inversamente a ideias de desestruturação e latência das relações sociais - como por referência aos ritmos e temporalidades de natureza sociológica que estruturam o ciclo anual no seu conjunto. Foi justamente à luz destes últimos que nos propusemos examinar, no caso de Santa Bárbara, as modalidades de articulação entre Impérios, estrutura social e tempo decorrentes do alargamento do tempo dos Impérios.

Este quadro geral permitiu-nos finalmente analisar o peso que ocupa nas Festas do Espírito Santo uma linguagem de poder. Por seu intermédio fomos confrontados com a importância do imperador ou do mordomo como figura de mediação entre a comunidade e a divindade e como figura através da qual aquela representa ciclicamente a sua unidade. O modo como esta figura é objecto de pressões ligadas a reivindicações de prestígio individual foi, por fim, objecto de discussão, particularmente detalhada para o caso de Santa Bárbara.

Propostas inicialmente a partir de um contexto preciso - constituído pela freguesia de Santa Bárbara - estas linhas de análise foram depois testadas por intermédio de dois estudos de caso, centrados nas freguesia de Santo Antão e da Piedade. Por seu intermédio, pudemos constatar o modo como, apesar da diversidade de soluções concretas que caracteriza as Festas do Espírito Santo nos Açores, estas se organizam em torno de um certo número de motivos unificadores, trabalhados entretanto de forma variável de contexto para contexto.

Posteriormente, o estudo das Romarias Quaresmais de São Miguel e o seu confronto com as Festas do Espírito Santo, permitiu-nos desenvolver alguns aspectos da lógica cíclica, de renovação e regeneração das relações sociais, que estas expressam.

\section{II}

Alguns dos temas que pusemos em evidência no decurso do livro são evidentemente específicos das Festas do Espírito Santo ou remetem-nos para particularidades do contexto etnográfico açoriano. Nessa medida este estudo deve ser visto, antes do mais, como uma contribuição para uma Antropologia Social dos Açores.

Nessa contribuição, há alguns aspectos mais relevantes que ressaltam. O primeiro diz respeito ao lugar central que o Espírito Santo ocupa no panteão religioso local. Configurando-se - apesar da sua importância na teolo- 
gia oficial da Igreja - como uma espécie de divindade secundária na devoção popular portuguesa, o Espírito Santo afirma-se nos Açores como o interlocutor divino principal do indivíduo e da comunidade e assume um papel que, noutros contextos, é preferencialmente assegurado pelos santos ou pelas invocações da Virgem. A marcada autonomia que o culto apresenta em relação à hierarquia eclesiástica deve ser também retida, assim como o relevo que nele ocupa uma concepção da promessa, baseada no dispêndio de elevadas quantidades de riquezas alimentares, que contrasta com aquelas que são as formas mais usuais de retribuição e agradecimento à divindade na religiosidade popular católica: penitência, ex-votos, ofertas monetárias.

$\mathrm{O}$ relevo que, em consequência, assume no ritual a linguagem da dádiva alimentar faz também das Festas do Espírito Santo um caso àparte na etnografia portuguesa e europeia. $\mathrm{O}$ carácter extremamente elaborado e minucioso do trabalho sociológico a que, por seu intermédio, as Festas do Espírito Santo se entregam, deve ser igualmente sublinhado. Esta associação entre cerimónias cíclicas e estrutura social - mediadada ou não pelo alimento - embora se possa reencontrar noutros contextos, atinge nas Festas do Espírito Santo dos Açores uma expressão particularmente relevante. Por seu intermédio não é, como em muitos outros casos, este ou aquele feixe de relações sociais que é posto em evidência, mas a totalidade do mapa da sociabilidade camponesa, nas suas múltiplas articulações, que se re-desenha periodicamente perante os nossos olhos.

Este mapa da sociabilidade possui, também ele, algumas características próprias, que tivemos ocasião de sublinhar, e que contrastam com soluções que, noutros contextos, são dadas a problemas de natureza similar. Entre essas características avulta, em primeiro lugar, a força do complexo sociológico formado pelas relações de parentesco e vizinhança. Esta característica deve ser tanto mais retida — como sublinhámos — quanto ele surge em articulação com o predomínio, ao nível da organização doméstica, da família elementar. Em segundo lugar, deve ser enfatizada a importância que possuem na organização social do arquipélago unidades como o lugar e a freguesia. O perfil e as formas de inter-relação dessas unidades possuem também traços próprios e aparecem combinadas com alguns temas recorrentes, como o relevo dos mecanismos de rivalidade inter-freguesias e o singular estatuto sociológico que caracteriza os lugares periféricos.

Finalmente, a importância que ocupa nas Festas do Espírito Santo uma linguagem de poder deve ser também posta em evidência. Embora presente noutras festividades cíclicas - como as Festas de Santo Estêvão em Trás-os-Montes ou certas variantes do São João na Beira Baixa ${ }^{1}$ - essa linguagem é, em larga medida, característica das Festas do Espírito Santo e atinge nelas, como vimos, uma expressão particularmente elaborada.

${ }^{1}$ A propósito das Festas de Santo Estêvão, cf. Pereira, Benjamim, 1973. Acerca do São João na Beira Baixa, cf. Lopes Dias, 1948, 143-154, 1953, 112-120. 


\section{III}

Mas ao mesmo tempo que são susceptíveis de fornecer um conjunto de elementos para uma Antropologia Social dos Açores, algumas das linhas de análise desenvolvidas no decurso deste estudo são passíveis de estimular uma reflexão em torno de problemáticas mais genéricas - como de resto as frequentes referências comparativas inseridas nos diferentes capítulos se encarregam de sugerir. A «insularidade» dos Açores, pelo menos de um ponto de vista antropológico, é bastante mais relativa do que possa parecer à primeira vista.

Entre essas problemáticas, conta-se, em primeiro lugar, a da dádiva. Se, como salientámos há instantes, o caso açoriano possui um certo número de especificidades, ele não é entretanto, no contexto rural europeu, um caso isolado, como o demonstram os estudos que citámos em «A Parte dos Homens I». Mas, por um lado, como também então pusemos em evidência, esses estudos possuem um carácter recente e disperso. E, por outro, não impedem que, paralelamente, a dádiva não continue a aparecer, noutros estudos, como um universo de análise subordinado a pressupostos «utilitaristas», que tendem a substituir a relação entre dádiva e relações sociais por uma perspectiva valorizadora do exclusivo «interesse individual». De uma forma ou de outra, e ao contrário do que tem sucedido com outras temáticas, a dádiva nunca se constituiu numa direcção de trabalho sistemática em domínio rural europeu, permanecendo em larga medida um terreno devoluto. Este desinteresse é tanto mais desconcertante quanto, de forma directa ou transversal, são numerosas as indicações etnográficas dispersas que testemunham da sua relevância. A marcação alimentar do ciclo cerimonial anual ou dos ritos de passagem é, por exemplo, suficientemente conhecida. Da mesma forma, a alimentação tem suscitado de forma duradoura a atenção dos etnólogos (cf., a título de exemplo, os estudos publicados em Larnott, 1975 ou em Fenton e Owen, 1981). Mas tanto num caso como noutro só raramente a reflexão se tem interessado pelas modalidades de circulação sociológica do alimento, pelo vínculo entre dádiva e relações sociais.

Uma das razões para esse «deficit» de interesse prende-se em grande medida com as próprias formulações que Mauss empregou no «Essai sur le Don» a esse respeito. De facto, embora Mauss - como assinalámos — se tenha referido na parte final do «Essai...» ao modo como o tema da dádiva poderia ser reencontrado em contexto rural europeu, fê-lo entretanto num quadro genérico marcado pela preocupação principal de indicar o modo como, apesar daquilo que ele designa como «a insensibilidade romana e saxónica do nosso regime» (Mauss, 1983a: 260) seria ainda possível reconhecer nas sociedades modernas vestígios, «sobrevivências» da dádiva «arcaica». Como Mauss escreve, «uma parte considerável da nossa moral e da nossa própria vida permanece estacionada nesta atmosfera da dádiva, da obrigação e da liberdade combinadas. Felizmente, nem tudo está ainda classificado exclusivamente em termos de compra e de venda (...). Não temos apenas uma moral de merca- 
dores. Restam-nos ainda pessoas e classes que possuem os costumes de outrora e aos quais quase todos nós nos submetemos, pelo menos em algumas épocas do ano ou em algumas ocasiões» [id., ibid.: 258 (os itálicos são meus)]. Como escreve Jacques Godbout, «Mauss parece ter tido dificuldade em reconhecer que a dádiva existe ainda hoje sem ser sob a forma de uma espécie de sobrevivência» (Godbout, 1992: 20) ${ }^{1}$

Essa conotação «arcaica» da dádiva em contexto rural europeu parece ter influenciado negativamente aqueles que, em antropologia europeia, procuraram e procuram construir um domínio de reflexão e interpretação liberto das conotações evolucionistas a que a construção de Mauss eventualmente se poderia prestar. Daí que o silêncio ou a utilização pontual de pressupostos utilitaristas se tenham tornado nas soluções mais correntes.

O presente estudo - em conjunto com os estudos a que fizemos anteriormente referência - sugere pelo contrário que o tema da dádiva deverá merecer uma atenção mais detalhada do que aquela que até agora tem recebido.

Nesse aspecto a antropologia europeia tem tudo a ganhar com a consideração atenta de alguns desenvolvimentos recentes em áreas afins. E o caso da sociologia e do modo como alguns dos seus praticantes têm crescentemente argumentado a favor de uma «redescoberta» da dádiva no contexto não apenas das sociedades rurais europeias mas da sociedade ocidental no seu conjunto. E em torno desse projecto teórico que se tem estruturado a produção dos investigadores reunidos em torno da «Revue du M.A.U.S.S.» Nesta merece particular destaque um trabalho recente de Jacques Godbout, em que o autor, defendendo que «a dádiva é tanto moderna e contemporânea como característica das sociedades arcaicas» (Godbout, 1992: 20), procura demonstrar o modo como a lógica da dádiva é essencial para análise do funcionamento da sociedade moderna, seja no registo das relações inter-pessoais, seja inclusivamente, embora de forma mais contraditória e complexa, no domínio de relações tuteladas por instituições como o estado ou o mercado.

A própria reflexão antropológica sobre as sociedades não-ocidentais tem vindo também a pôr em evidência a ideia que os processos de transformação social dessas sociedades, nomeadamente no que diz respeito à tendência para a monetarização das suas economias, não são forçosamente sinónimo - como o pretendem muitos outros antropólogos - de uma ruptura irreversível com o universo da dádiva. E nesse quadro que devem ser lidos alguns dos ensaios reunidos por Jonathan Parry e Maurice Bloch em «Money and the Morality of Exchange» (Parry e Bloch, 1989), onde se procura justamente complexificar a inter-relação existente entre uma esfera de trocas baseada na lógica da dádiva e uma esfera de trocas assente numa lógica monetária.

\footnotetext{
${ }^{1}$ Para uma exploração dos aspectos «evolucionistas» da reflexão de Mauss acerca da dádiva, cf. ainda a parte inicial do ensaio que Jonathan Parry consagrou ao estudo da dádiva em contexto indiano (Parry, 1986: 453-458).
} 


\section{IV}

Simultaneamente, as linhas interpretativas desenvolvidas no decurso deste estudo sugerem que na análise das cerimónias cíclicas em contexto europeu, uma maior atenção deve ser conferida ao vínculo existente entre ritual, relações sociais e tempo.

Desse ponto de vista, vale a pena sublinhar, em primeiro lugar, o modo como algumas das linhas de análise construídas em torno das Festas do Espírito Santo e das relações de complementariedade que as ligam aos «ciclos» da Quaresma e do Carnaval são susceptíveis de esclarecer algumas das formulações mais usuais que recebe na tradição geral portuguesa e europeia esse longo e decisivo arco cerimonial integrado pelos «ciclos» do Carnaval, da Quaresma, da Páscoa e de Maio ${ }^{1}$.

Comecemos por estes dois últimos «ciclos». Desenrolando-se ao longo do período que, nos Açores, é consagrado às Festas do Espírito Santo, os «ciclos» da Páscoa e de Maio obedecem de facto a ideias genericamente similares àquelas que começámos por detectar nesse contexto cerimonial. Assim, a marcação alimentar do «ciclo» da Páscoa - assente em ofertas defolares e noutras refeições cerimoniais ${ }^{2}$ — vincula esse período do calendário cerimonial anual a ideias muito claras de reiteração cíclica das relações sociais. Circulando preferencialmente entre padrinhos e afilhados, os folares, além de operarem como um instrumento de reafirmação periódica da relação de apadrinhamento em si, recebem de facto um significado sociológico mais vasto decorrente da articulação das regras de escolha de padrinhos com mecanismos de asserção dos laços de parentesco, de amizade ou do patrocinato (cf., a este propósito, Callier-Boisvert, 1968). O modo como, em muitos casos, estas dádivas se estendem informalmente a outras unidades domésticas de parentes, vizinhos ou amigos, deve ser olhado à luz da mesma perspectiva. Simultaneamente, o «ciclo» da Páscoa liga-se também, por intermédio do compasso pascal, a ideias de reafirmação de laços sociais mais amplos, como aqueles que se prendem com a pertença à comunidade (cf., por exemplo, Pina Cabral, 1986: 134).

Paralelamente, as cerimónias que integram os «ciclos» da Páscoa e de Maio $^{3}$ reservam também um papel fundamental a ideias de renascimento da

\footnotetext{
${ }^{1}$ As propostas de análise desenvolvidas nas próximas páginas foram objecto de um tratamento mais detalhado na versão inicial deste estudo e encontram-se parcialmente transcritas em Leal 1991a, 1991b e 1991c.

${ }^{2}$ Para uma apresentação etnográfica detalhada dos principais aspectos do «ciclo» da Páscoa em Portugal, cf. Veiga de Oliveira 1984e. Para aspectos complementares relacionados com as refeições desta quadra, cf. Teixeira, 1991: 195-196.

${ }^{3}$ Para uma apresentação etnográfica detalhada dos principais aspectos do «ciclo» de Maio em Portugal, cf. Veiga de Oliveira 1984f e 1984g. Relativamente às comemorações do dia 3 de Maio — dia em que a Igreja celebra a Invenção da Santa Cruz — cf. Vasconcelos, 1982: 274-280.
} 
natureza e de regeneração da fertilidade. As ideias de regeneração da fertilidade são particularmente claras no «ciclo» da Páscoa e derivam não apenas da marcação alimentar da data mas do papel fundamental reservado ao ovo nos alimentos cerimoniais próprios da ocasião. Simultaneamente o «ciclo» da Páscoa articula-se com ideias de renascimento da natureza, expressas, por exemplo, no relevo que têm, no compasso pascal, um certo número de decorações florais. Da mesma forma é também conhecida a ligação do ritual do Enterro do Bacalhau - que assinala o termo das proibições alimentares da Quaresma - a «batalhas de flores» (cf. Cardoso, 1982: 63 e 64). Mas é sobretudo no «ciclo» de Maio que essas ideias de renovação e renascimento da natureza se exprimem de forma mais importante. Um dos aspectos centrais dos rituais em que se desdobra esse «ciclo» é o peso que neles assume um conjunto de práticas relacionadas com a vegetação: apanha da espiga em 5. ${ }^{a}$ feira de Ascensão, decoração florais e personagens de forte conotação vegetal nas Maias, decorações florais de cruzes no dia 3 de Maio.

Simultaneamente, as Maias põem-nos perante formas de simbolização das ideias de renascimento similares àquelas que pudémos encontrar em torno das Festas do Espírito Santo. De facto, é a cargo de um grupo etário integrado por adolescentes ou crianças que se encontram os festejos, com relevo para as representações vegetais do ciclo - Maio moço ou Maia. Neste último caso, simultaneamente ao código etário, reencontramos ainda a utilização da figura feminina como instrumento de representação dessas ideias.

Quanto à ligação da Quaresma a ideias de morte e latência social, ela expressava-se com particular clareza no quadro de um ritual - conhecido pela designação de Encomendação das Almas - - que até aos anos 40/50 marcava em plano de relevo a paisagem cultural portuguesa ${ }^{1}$ Centrada na oração pelas almas do purgatório, a Encomendação das Almas, em contraponto com as ideias de vida e renovação dominantes nos «ciclos» da Páscoa e de Maio aparecia de facto privilegiadamente associada ao tema da morte. Simultaneamente, era também muito forte a sua vinculação a ideias de latência social, envolvendo quer os protagonistas do ritual - os encomendadores - quer o corpo social no seu conjunto. Os primeiros ocupavam momentaneamente uma situação intermédia entre o mundo dos vivos e o mundo dos

\footnotetext{
${ }^{1}$ Com origens provavelmente eclesiásticas que se combinaram posteriormente com elaborações populares, a Encomendação das Almas foi estudada de uma forma sistemática por Jorge e Margot Dias (cf. Dias, A. Jorge e Margot, 1950 e 1956). É difícil, no estado actual da investigação, datar com segurança as suas origens. Jorge e Margot Dias fazem-nas remontar à Idade Média. Mas outros autores têm sugerido a sua ligação ao período da Reforma Católica. A área de difusão do ritual parece circunscrever-se na Europa, a Portugal. Daí que Jorge e Margot Dias o tenham definido como um ritual que «conferia carácter diferenciador à nossa cultura popular em relação às outras culturas europeias» (1950: 593). Dada a sua existência nas ilhas e no Brasil, ambos os autores vieram depois a considerá-lo um ritual característico daquilo que designam como a área cultural luso-brasileira (Cf. Dias, A. Jorge e Margot, 1956).
} 
mortos, expressa por exemplo nalguns dos locais escolhidos para a oração cemitérios, encruzilhadas, casas abandonadas - ou no conjunto de protecções mágicas de que se rodeavam. Esta situação liminar era ainda sublinhada por certos detalhes do ritual: os encomendadores deviam cobrir-se «com mantas ou capotes para não serem reconhecidos», não podiam «falar a mais ninguém depois de sairem de casa» e «deviam procurar o escuro para não poderem ser vistos» (Cortes-Rodrigues, 1942/45: 17). Simultaneamente, o ritual determinava uma momentânea suspensão da vida social no seu conjunto: as pessoas deviam permanecer em suas casas, rezando as orações pedidas pelos encomendadores, e qualquer contacto com o exterior era considerado como particularmente perigoso.

Finalmente é de acordo com ideias de desestruturação das relações sociais que podem ser analisados os principais motivos que caracterizam, na tradição geral portuguesa, o «ciclo» do Carnaval ${ }^{1}$. Alguns desses motivos apresentam similitudes genéricas com aqueles que pusémos em evidência a propósito de Santa Bárbara e podem ser analisados à luz de critérios idênticos aos que então empregámos. É o que se passa, por exemplo, com a marcação alimentar do Carnaval ou com a sua articulação com personagens mascarados. Simultaneamente, as ideias de desestruturação das relações sociais a que o Carnaval se vincula recebem uma expressão particularmente forte através da sua recorrente associação a pulhas e testamentos jocosos — estes últimos articulados com a queima de efígies figurando o Carnaval —, por intermédio dos quais se assiste a uma momentânea subversão das regras que presidem ao relacionamento social corrente. E a uma luz idêntica que pode ser também interpretada o sentido geral das celebrações das 5. ${ }^{\text {as }}$ Feiras dos Compadres e das Comadres, que, antecedendo o Carnaval propriamente dito, «assinalam (...) a chegada do Entrudo com as suas folias e liberdades» (Veiga de Oliveira, 1984c: 53). Obedecendo, por um lado, a ideias de «glorificação do próprio grupo sexual no seu dia respectivo — os homens na quinta-feira dos Compadres e as mulheres na quinta feira das Comadres» e, por outro, a ideias de «oposição para com o grupo contrário, traduzindo-se em troças, perseguições ou lutas jocosas, simbólicas ou mesmo por vezes efectivas, e na solidariedade operante entre todos os indivíduos do mesmo sexo em contraposição aos do outro sexo» (id., ibid.), estas celebrações encenam uma momentânea e violenta ruptura nas relações de complementariedade entre os dois sexos que constitui uma das características fundamentais da organização social. Fazendo-se sentir a vários níveis - comunidade, grupos de idade, unidades domésticas - essa ruptura é ainda frequentemente acompanhada de uma suspensão e inversão dos papéis tradicionalmente atribuídos a cada um dos sexos: a

\footnotetext{
${ }^{1}$ Para uma apresentação etnográfica detalhada dos principais aspectos do «ciclo» do Carnaval em Portugal cf. Veiga de Oliveira, 1984a, 1984b, 1984c e 1984d.
} 
quinta-feira das Comadres aparece associado a ideias de momentâneo exercício da autoridade por parte das mulheres, ao passo que, nalgumas áreas, os homens, na quinta-feira dos Compadres, asseguram tarefas culinárias usualmente cometidas às mulheres. Em torno desta oposição geral entre os grupos sexuais masculino e feminino gera-se, finalmente, um ambiente geral de licenciosidade e troça, de lutas e insultos, que rompe momentaneamente o ordem social estabelecida.

Isto é: apoiando-se em rituais por vezes distintos, seguindo caminhos muitas vezes diferenciados, a lógica cíclica que começámos por identificar em torno das Festas do Espírito Santo nos Açores é pois reencontrável no quadro da sucessão formado pelos «ciclos» do Carnaval, Quaresma, Páscoa e Maio, tal como esta se configurava tradicionalmente na cultura popular portuguesa e, em certa medida, europeia ${ }^{1}$. Por seu intermédio, somos confrontados com a centralidade desse vínculo entre cerimónias cíclicas, relações sociais e tempo que começámos por referir a propósito dos Açores.

Simultaneamente, a análise conduzida no decurso deste estudo confrontou-nos também com a plasticidade desse vínculo, com a sua capacidade de abertura à história. Como tivemos oportunidade de constatar no Capítulo consagrado ao «Tempo dos Impérios», as Festas do Espírito Santo em Santa Bárbara, ao mesmo tempo que continuam associadas a uma lógica dependente da sua calendarização tradicional, têm-se vindo a abrir, em resultado do alargamento do tempo dos Impérios, para novas formas de articulação entre estrutura social e tempo que lhes acrescentam características de um instrumento do cíclico «refazer» de uma comunidade dividida pela emigração.

Um certo número de estudos recentes têm-se encarregado de sugerir que processos aparentados se podem reencontrar noutros contextos rurais europeus. Assim, nas conclusões de um estudo dedicado às transformações recentes do ciclo festivo num conjunto de aldeias do NW da Estremadura espanhola, Cruces e Diaz de Rada, depois de chamarem a atenção para a importância crescente das festas de verão, relacionam-nas com a celebração da unidade de populações separadas pela emigração: «pode afirmar-se que a comunidade enquanto rede de relações sociais só se encontra completa durante os meses de Verão. Assim, um novo ciclo, dependente das férias urbanas, foi acrescentado ao ciclo agrícola e aos calendários litúrgicos e nacionais» (Cruces e Diaz de Rada, 1992: 66). Baseando-se nas conclusões deste e doutros estudos de caso, Boissevain chamou também a atenção para a emergência de novos padrões de relacionamento entre o ciclo festivo e as formas de construção

${ }^{1}$ Com excepção da Encomendação das Almas - cuja difusão na Europa se circunscreve, como assinalámos, a Portugal - uma parte importante dos motivos que passámos em revista é de facto reencontrável na tradição geral europeia. Cf., para França, Van Gennep, 1947 e 1949, a para Espanha, Caro Baroja, 1979a e 1979b. 
social do tempo. Dois factores seriam determinantes nessa situação: o enfraquecimento das relações entre o ciclo festivo e o ciclo agrário e a passagem generalizada das principais festas para o verão: «tal representa uma nova harmonização do ciclo ritual e do ciclo produtivo, porque eles se baseiam agora no novo ciclo do trabalho-lazer do regime industrial na Europa» (Boissevain, 1992: 12). Neste quadro, enquanto que os rituais de inverno se caracterizariam pelo seu carácter fechado e restrito, «as festas de Verão celebram a comunidade alargada, incluindo diversos emigrantes em férias, veraneantes, pessoas recém-chegadas e turistas» (id. ibid.).

Evidenciando a capacidade de metamorfose do vínculo entre rituais cíclicos, relações sócias e tempo, estas análises, em conjunto com as nossas próprias conclusões, dão uma força acrescida àquele que constituiu um dos argumentos centrais deste estudo. Parafraseando Pierre Smith, mais do que «uma simples exposição dos mecanismos sociais» (Smith, P., 1979: 139), as cerimónias cíclicas são uma peça essencial de um empreeendimento onde tempo e relações sociais são pensados e trabalhados em conjunto. 
APÊNDICE A

FESTAS DO ESPíRITO SANTO, POVO E CLERO 
Tivemos ocasião, no decurso deste estudo, de insistir sobre a relação de marcada autonomia que as Festas do Espírito Santo exibem em relação à Igreja.

Essa autonomia expressa-se a vários níveis. Ela encontra-se desde logo inscrita nas modalidades de organização a que os festejos obedecem. Assim, quando estes resultam de promessa, esta suprime o padre enquanto mediador institucional entre o fiel e a divindade. O «contrato» é estabelecido directamente com a divindade e eventuais interferências do clero são mal aceites. Por outro lado, tanto as irmandades como outras formas de enquadramento institucional dos festejos encontram-se, como tivemos ocasião de sublinhar, totalmente independentes da Igreja. A própria estrutura das Festas é elucidativa do seu grau de autonomia em relação ao aparelho religioso. O dispêndio monetário que estas acarretam exclui quaisquer prestações canalizadas para o financiamento do culto usual. E a interferência do padre no desenrolar dos festejos circunscreve-se às bênçãos de alimentos e à imposição da(s) Coroa(s) no quadro da coroação. Esta autonomia das Festas do Espírito Santo em relação à Igreja atinge ainda, em certos casos, expressões mais enfáticas. E o que se passa, como tivemos oportunidade de ver, em Santa Bárbara, onde o imperador, assumindo-se por um lado como um mediador na relação entre a comunidade e a divindade e, por outro, como uma figura por intermédio da qual é pensada a identidade da comunidade, usurpa momentaneamente funções religiosas e sociais usualmente atribuídas ao padre.

Simultaneamente a esta autonomia, as Festas do Espírito Santo são marcadas em plano de relevo por um conjunto de formulações «sui generis» - em que avultam, para além das diferentes modalidades de circulação do alimento, cerimónias religiosas como as alumiações, as alvoradas e a própria coroação - que as tendem a situar no terreno daquilo que se convencionou chamar de «religiosidade popular». 
Devido a estas duas razões, as relações entre a Igreja e as Festas do Espírito Santo, quer ao nível central, quer ao nível local, não têm sido isentas de conflitos.

Ao nível central, a Igreja, tem procurado por diversas vezes intervir nas Festas do Espírito Santo, através de um conjunto de «censuras e leis» - como lhes chama J. A. Pereira (1950) - emitidas tanto sob a forma de documentos episcopais, como sob a forma de proibições ou recomendações efectuadas por ocasião de visitas às diferentes paróquias do arquipélago.

Para o período anterior ao séc. XIX dispomos de um inventário parcial dessas «censuras e leis», realizado justamente por J. A. Pereira (1950). Nas Constituições do Bispado de Angra do Heroísmo, publicadas em 1560, depois de se constatar a presença de imperadores «em muitos domingos e festas do ano» (Pereira. J. A., 1950: 58), estatui-se que «não se façam festas de Imperadores senão na festa do Espírito Santo» e «nas procissões de Corpus-Christi, Visitação ou do Anjo» e que, em qualquer dos casos, não «haja dois, nem Imperador e Imperatriz juntamente, senão um só». As Constituições advertem ainda que «quando entrarem nas igrejas com o Imperador ou Imperatriz, entrem honestamente sem arruído de vozes e sem tangeres, nas quais igrejas não estarão mais tempo que aos ofícios divinos ou fazer oração e passar» (id., ibid.: 59). Alguns anos mais tarde o bispo D. Jerónimo Teixeira (1600-1612) proibiu que os foliões «bailassem na Capela-mór das Igrejas» tendo um seu visitador acrescentado a essa proibição a de os foliões entrarem «na igreja a cantar cantigas profanas» (id., ibid.) Em 1645, um outro visitador eclesiástico proibiu na freguesia dos Altares (Terceira) a deslocação do pároco a casa do imperador, os «ministros eclesiásticos não assistirão à mesa dos imperadores nem irão a suas casas a dar-lhes o ceptro nem tirar-lhes a coroa» (id. ibid.). Mais tarde, o Bispo Dom António Vieira Leitão (1694-1714) proibiu por seu turno os Impérios de mulheres, argumentando com os «enfeites indecorosos e profanos de que as ditas mulheres usam em tais actos» e com o «concurso de homens que a eles vão com práticas indecentes e outras enormidades de que resulta geral escândalo» (id., ibid.: 60). O mesmo Bispo determinou ainda que «não houvesse em cada freguesia mais do que um Império do Espírito Santo» (id., ibid.). No artigo que temos vindo a citar são ainda referidas duas Pastorais, datadas respectivamente de 1841 e 1843, em que são feitas referências, de tom bastante violento, às Festas do Espírito Santo. Na primeira o Bispo adverte os fiéis «que se abstenham daqueles divertimentos que, em si e nas suas circunstâncias, envolvam crimes e pecados, como são os que se cometem nos dias da coroação do Espírito Santo, debaixo do falso pretexto 
de mais festejo e devoção» (id., ibid.). Na segunda são reprovados «os abusos, os excessos criminosos de qualquer natureza que sejam, com que se tem praticado e se houver de praticar a mais bem entendida devoção deste Senhor» (id., ibid.: 60-61).

Mas é sobretudo a partir do último quartel do séc. XIX - com a criação, em 1875, do «Boletim do Governo Eclesiástico dos Açores» — que a intervenção da Igreja se torna mais sistemática. Em 1876, o Bispo Dom João Maria Pimentel, depois de constatar que «em algumas freguesias há o costume de nos bodos do Espírito Santo acompanharem Imagens de Santos o préstito, com o título de pagens da coroa» ordena que «daqui em diante nenhuma Imagem saia da sua Igreja ou Capela para acompanhar tais préstitos» (Pastoral, 1876: 323-324). Em 1881, o mesmo Bispo, numa "Circular aos Mtos. Revdos. Párocos», depois de fazer alusão a «providências» tomadas pelos seus antecessores em relação às Festas do Espírito Santo, constata que, apesar delas, «novos abusos aparecem que é indispensável reprimir». Assim, têm sido introduzidas nos festejos «coroas de lata, as quais se põem em exposição pública em casas particulares, onde se reúnem muitas pessoas a título de honrarem o Divino Espírito Santo, mas onde é na verdade desacatado; porque em lugar de se dedicarem essas pessoas à oração e actos de piedade, se entretém em jogos, danças e actos profanos, com que se ofende e não honra a Divindade; e que muitas vezes, para pretexto de tais festas, se fazem votos indiscretos, que é conveniente coibir. Que da mesma sorte se abusa também muitas vezes da exposição das coroas decentes de prata no tempo que decorre entre o Domingo de Páscoa e a Dominga da SS. Trindade» (Circular..., 1881a: 250-251). Para reprimir tais «abusos», a Circular determina: «1. ${ }^{\circ}$ Que ninguém se ache habilitado para benzer coroas do Espírito Santo que não sejam de prata. $2 .^{\circ}$ Declaramos profanadas e indignas do culto dado ao mesmo Santo Espírito todas as coroas que não forem daquele metal. $3 .^{\circ}$ Proibimos novamente que se exponha a Coroa do Espírito Santo, e se façam festas ao mesmo fora do tempo que decorre da dominga de Páscoa à da SS. Trindade, sem licença nossa ou do Mto. Rvdo. Ouvidor, ouvido o respectivo Pároco: a qual se não concederá senão por justos e ponderosos motivos. $4 .^{\circ}$ Por ocasião de estar a coroa em casas particulares, não se praticarão ali outros actos que não sejam de oração e piedade. $5 .^{\circ}$ Logo que outra coisa conste ao respectivo Pároco, mandará tirar de tal casa a coroa de que se tenha abusado, e não prestará honras algumas religiosas a tais festas. $6 .^{\circ}$ As coroas decentes destinadas ao culto público serão conservadas nas Igrejas e, em casas particulares, só com licença do respectivo Pároco, não sendo licito expô-las ao culto público e iluminá-las, a não ser no tempo pascal declarado, ou com a necessária licença (...). 7. ${ }^{\circ}$ É inteiramente proibido coroar mulheres, ainda menores, e de qualquer modo que seja» (id. ibid.: 251). Ainda no mesmo ano, numa nova Circular, são por seu turno proibidas as mascaradas a que, nalguns lugares, as Festas do Espírito Santo dariam origem (Circular..., 1881b: 274-275). 
Alguns anos depois, em 1894, no seguimento das «Conferências do Clero» de Angra, são tomadas também um conjunto de «Resoluções» relativas às Festas do Espírito Santo. A linguagem é porém muito diferente da utilizada nas «Circulares» que acabámos de referir. Depois de constatarem «que a devoção mais simpática e que se manifesta com mais entusiasmo de fé ardente no povo açoriano é, sem dúvida alguma, a devoção à Terceira Pessoa da Santíssima Trindade» (Resoluções..., 1895: 129), as Resoluções acrescentam que «com esta devoção tão popular se dá uma especialidade, que não se encontra em qualquer outra, e consiste ela em que o povo é que tem legislado, permita-se o termo, sobre o modo de prestar este culto, e que por isso não admira que haja alguns abusos filhos do seu delírio religioso» (id., ibid.: 130). Entre esses abusos contar-se-iam: a) «o andar a coroa do Espírito Santo, levada por homens ou rapazes, em peditório pelas ruas e praças públicas e até pelas tabernas» (id. ibid.); b) «não só deixar de se prestar o costumado culto do Espírito Santo nas casas que recebem a coroa, mas praticar-se ali actos bem pouco próprios da ocasião, tais como danças, jogos, descantes populares e outros divertimentos profanos» (id., ibid.); c) «levantarem-se impérios nos cantos das ruas e nos quais quase sempre se expõem ao culto público coroas de lata e portanto profanadas» (id. ibid.: 131); d) «o costume de serem feitas em casa as coroações» (id., ibid.); e) «o modo pouco regular como muitas vezes são feitas as mudanças de coroas», como «quando o acompanhamento se realiza à noite, à luz dos archotes, com mulheres em cabelo» (id., ibid.: 132). Considerando serem de combater estes e outros abusos - todos eles já denunciados e até proibidos em documentação anterior - as Resoluções entendem entretanto que, para o efeito, «não há outro meio senão o zelo religioso do pároco, manifestado em exortações paternais, feitas com prudência, de modo a calar profundamente no ânimo dos paroquianos» (id., ibid.: 130), acrescentando - em contradição com o estipulado numa das Circulares de 1881 que «o pároco deve sempre prestar as honras devidas ao emblema do Divino Espírito Santo, não obstante a existência de qualquer abuso, e mesmo quando a desobediência às suas determinações seja motivo para deixar de coroar o respectivo imperador» (id., ibid.: 135). Na mesma linha, as Resoluções insistem ainda que «o pároco deve ser completamente estranho a tudo o que diz respeito à administração dos impérios» só lhe cabendo «olhar pelos actos que se praticam diante da coroa, a fim de evitar irreverências» (id., ibid.: 134). Por fim, as Resoluções procedem à regulamentação litúrgica da cerimónia da coroação ${ }^{1}$, insistindo em que «é conveniente que a pessoa que tem de ser coroada se confesse e comungue nesse dia para assim dar testemunho bem claro de que o sentimento religioso foi quem promoveu aquele acto»

\footnotetext{
${ }^{1}$ Essa regulamentação litúrgica ainda se encontra em vigor. Tivemos ocasião de referir alguns dos seus aspectos mais importantes aquando da descrição da cerimónia da coroação na freguesia de Santa Bárbara (cf. Capítulo 2, p. 46).
} 
(id., ibid.: 132) e especificam que «todo e qualquer fiel do sexo masculino poderá ser admitido à coroação; e do sexo feminino até à idade de dez anos» (id., ibid.: 133).

Em 1924, a cerimónia da coroação é de novo alvo de uma determinação episcopal que a torna indissociável da missa, sendo novamente proibidas as «coroações em casas particulares e impérios» (Coroações, 1924: 273). Em 1925, uma outra Provisão, ao mesmo tempo que confirma estas determinações, especifica que, quando eventualmente autorizadas «fora do tempo da missa», as coroações "serão efectuadas em seguida a qualquer outro acto de devoção e piedade, como a recitação do Terço de Nossa Senhora, a Hora de Adoração ao Santíssimo Sacramento, etc...» (Provisão, 1925: 43).

Em 1959, é de novo adoptada legislação referente às Festas do Espírito Santo. A linguagem usada é, tal como nas Provisões de 1895, bastante moderada. Pondo em evidência a religiosidade do povo açoriano, o Bispo Dom Manuel Afonso de Carvalho refere que «neste ambiente de alta religiosidade, uma devoção há que se distingue das demais, já pelo seu fundamento, pois é a base de toda a santidade, já pela importância do seu objecto, indo directamente à SSma. Trindade - a devoção ao Divino Espírito Santo. Não há certamente terra nos Açores, lugar por mais recôndito ou afastado onde se não tenha ouvido falar, fiel por mais rude, que não conheça o Divino Espírito Santo. Aqui, graças sejam dadas ao Senhor, não acontece o que nos vem descrito nos Actos dos Apóstolos, quando S. Paulo visitou os Efésios e, tendo-lhes perguntado se haviam recebido o Espírito Santo, obteve como resposta: nem sequer ouvimos se o Espírito Santo existe [Act. XIX, 2]. Todos os fiéis, felizmente conhecem, amam e honram o Divino Espírito Santo com um culto especial» (O Culto do Divino Espírito Santo, 1959: 431). Entretanto, refere o documento, a «forma exterior» desse culto «nem sempre e em todos os lugares estará conforme à doutrina da Santa Igreja. Urge, portanto, não destruir, não menosprezar ou censurar as atitudes do povo bom, mas orientá-lo, formá-lo nos princípios da verdadeira doutrina, para que, mais e melhor, preste culto à Terceira Pessoa da Santíssima Trindade» (id., ibid.: 432). Com esse objectivo são, em primeiro lugar, confirmadas algumas censuras e leis anteriores. Assim, «não serão permitidos, por ocasião das festas do Espírito Santo, divertimentos profanos que redundem em ofensa de Deus nem tolerados cortejos com meninas de idade superior a 12 anos completos e não decentemente vestidas» (id., ibid.: 433). Quanto às coroações deverão realizar-se «imediatamente antes da missa ou no fim da mesma, conforme os costumes locais, apenas durante o tempo pascal, a não ser em casos especiais mediante licença nossa dada por escrito» (id., ibid.). Simultaneamente - e no seguimento de uma recomendação já formulada por ocasião das Resoluções de 1895 — é instituída a criação obrigatória, em todas as paróquias, de uma «Irmandade do Espírito Santo, com personalidade jurídica» (id., ibid.: 432) à qual deverão pertencer todos aqueles que tomem " parte activa em actos de culto ao Divino Espírito Santo» (id., ibid.: 433). Inspiradas num modelo estatutário 


\section{AS FESTAS DO ESPÍRITO SANTO NOS AÇORES}

único, inserido em anexo, essas irmandades parecem ter como objectivo proceder a um enquadramento eclesiástico do culto do Espírito Santo. E aliás conhecido que no decurso da prelatura do Bispo Dom Manuel Afonso de Carvalho houve algumas tentativas, baseadas em directrizes episcopais, de colocar sob a alçada da Igreja os fundos administrados pelos Impérios.

III

Ao nível local, são também conhecidas tentativas de interferência do clero relativamente a aspectos da organização tradicional das Festas do Espírito Santo, usualmente geradoras de incidentes com as populações.

Um desses incidentes foi objecto de uma «Pastoral aos Fiéis da Freguesia de N. S. dos Remédios da Fajãzinha das Flores», assinada por Dom João Maria Pimentel (Pastoral aos Fiéis..., 1876: 289-292). Depreende-se do texto da Pastoral que teria havido um conflito entre parte da população e o pároco local sobre o papel que este deveria desempenhar nos festejos. No seguimento, a freguesia parece ter-se dividido em dois «partidos» rivais, cujas hostilidades teriam desencadeado uma intervenção policial da autoridade administrativa (id., ibid.: 290). Incidentes com características similares são reencontráveis noutras freguesias açorianas. Sem preocupação de exaustividade, vale a pena referir alguns dos que tomámos conhecimento no decurso da nossa pesquisa de terreno nos Açores.

Ainda nas Flores, mas na freguesia de Ponta Delgada, teve lugar nos anos 60 e 70 um conflito de longa duração entre a população da freguesia e o pároco, aparentemente provocado por tentativas de ingerência deste na administração dos fundos dos Impérios. Na freguesia existiam quatro Casas do Espirito Santo que promoviam festejos distintos e, entre 1967 e 1974, três delas, como forma de protesto contra a acção do padre, deixaram de promover os respectivos Impérios. Formaram-se dois «partidos» na freguesia, um a favor do padre, outro contra ele, e, no decurso desse período, os elementos mais em evidência do «partido» contrário ao padre nem sequer frequentavam a missa dominical.

Em Santo Antão (São Jorge), nos anos 40, o pároco local tomou também algumas iniciativas contra as Festas do Espírito Santo. Entre elas, conta-se a retirada de circulação, à revelia da população, das tochas usualmente utilizadas no acompanhamento das mudanças de Coroa. Mais tarde, tirando partido de um incidente ocorrido no decurso da estada das Coroas em casa de um mordomo - o soalho da divisão em que estava instalado o altar do Espírito Santo cedeu devido ao peso das pessoas que lá se encontravam - o padre proibiu a instalação das Coroas em casa dos mordomos que tinham a seu cargo a promoção dos festejos. Embora tenham sido invocadas razões de segurança, o verdadeiro propósito do padre era, segundo é afirmado localmente, o de pôr termo 
aos «divertimentos» a que dava tradicionalmente lugar a realização do terço. Embora, nestes dois casos, não tenha existido uma reacção organizada da população contra essas medidas, elas foram exploradas - no âmbito de um conflito que tivémos ocasião de referir no Capítulo 9 - pelo «partido do médico» como forma de aprofundar a contestação ao «partido do padre».

Em Santa Bárbara (Santa Maria), os anos 40 foram também assinalados por um conjunto de incidentes entre o pároco e a população da freguesia em torno dos Impérios. Apresentado como particularmente adverso ao culto do Espírito Santo - «aquele homem não tinha fé no Espírito Santo» - esse padre tomou um conjunto de iniciativas contra os Impérios: violentas prédicas na Igreja contra os festejos, pressões sobre pessoas que estavam «devendo promessas ao Espírito Santo» para que as satisfizessem de outra forma, recusas em coroar imperadores, e, sobretudo, a destruição de uma das duas Coroas então afectas à Igreja paroquial, com o argumento de que a prata poderia ser melhor utilizada para o fabrico de alfaias litúrgicas de que a Igreja estava carecida; a Coroa veio efectivamente a ser fundida com esse objectivo e, devido ao facto, esse padre ainda hoje é referido, entre as pessoas mais idosas, como «o padre que conseguiu levar o Espírito Santo à frigideira». Mais recentemente, no decurso dos anos 80 , um outro padre que esteve à frente da freguesia tomou também algumas atitudes de hostilidade em relação aos Impérios, tecendo publicamente críticas a alguns dos seus aspectos, pressionando igualmente alguns imperadores para mudanças de promessa e chegando mesmo ao ponto de se recusar a benzer um Jantar. Esta última atitude suscitou na altura uma forte celeuma na freguesia: além de críticas generalizadas, houve mesmo quem de forma velada falasse na necessidade de «dar uma lição ao padre».

\section{IV}

A partir de factos idênticos a estes, certos autores têm proposto uma caracterização particularmente radical da relação entre as Festas do Espírito Santo e a Igreja nos Açores. E o caso de Mari Lynn Salvador. Para ela, «a crença no Espírito Santo baseia-se na teologia católica. No entanto, as celebrações açorianas do Espírito Santo são sancionadas, apenas de forma relutante, pela Igreja. Elas têm uma longa história de conflito com a Igreja e resistiram, com sucesso, às tentativas deliberadas de as banir» (Salvador, 1981: 46). «Estas celebrações não são aceites pela Igreja Católica, apesar da participação ocasional de padres isolados. Ao longo dos séculos e, mais recentemente, nos anos 50, os esforços sistemáticos para erradicar o ritual encontraram uma resistência firme e bem sucedida nos Açores» (id., ibid.: 49).

Torna-se difícil subscrever este tipo de formulações. Ao nível da legislação episcopal, não só não se descortina um propósito explícito de proibir ou 
erradicar as Festas como uma análise mais cuidada dessa produção legislativa se encarrega de pôr em evidência o seu alcance algo limitado. De facto, as «censuras e leis» adoptadas ao longo dos tempos pela Igreja açoriana acabam por se concentrar num número restrito de aspectos da organização ritual das Festas do Espírito Santo. No plano repressivo, as suas preocupações centrais são, por um lado, a de evitar o que é definido como atitudes de «desrespeito» e «irreverência» em relação à Coroa do Espírito Santo, e, por outro, a de disciplinar ou mesmo eliminar alguns «divertimentos profanos» a que os festejos dariam lugar e que a Igreja considera incompatíveis com os propósitos religiosos do culto do Espírito Santo. No plano normativo, essas «censuras e leis» têm como objectivo central inscrever algumas formas de religiosidade próprias do culto do Espírito Santo no quadro das formas oficiais de devoção católica: as diversas tentativas de regulamentação da cerimónia da coroação são particularmente expressivas desta última linha de acção.

Isto é: no fundamental, e tendo em conta a estrutura geral das Festas do Espírito Santo, pode-se dizer que a intervenção da Igreja mantém intocáveis os aspectos estruturadores centrais do ritual, em particular aqueles em relação aos quais se poderia esperar uma actuação mais firme da Igreja. E o que se passa com a marcada autonomia das Festas do Espírito Santo face ao aparelho religioso. Esta não só não é posta em causa como é explicitamente admitida pela Igreja, quando, por exemplo, esta constata, nas «Resoluções das Conferências do Clero de Angra» de 1894 que em matéria do culto do Espírito Santo «o povo é que tem legislado» (Resoluções..., 1895: 130), ou, quando nas mesmas «Resoluções...» se recomenda ao clero que se afaste da administração dos Impérios. Postura idêntica havia aliás sido adoptada já em 1876, pelo Bispo Dom João Maria Pimentel. No seguimento dos incidentes registados em torno das Festas do Espírito Santo da freguesia da Fajãzinha (Flores) a que atrás fizemos alusão, determinou-se que «os párocos não se intrometam (...) nos negócios temporais» das irmandades do Espírito Santo, «nem se encarreguem ou tomem parte na administração de seus fundos e rendimentos» (Pastoral aos Fiéis..., 1876: 330). Mais recentemente, em 1959, é significativo que a criação de Irmandades do Espírito Santo de acordo com um modelo eclesiásticamente definido não tivesse como objectivo a substituição das estruturas tradicionais de enquadramento institucional das Festas, que se mantiveram intactas. De forma idêntica, o conjunto de formulações que de uma forma mais clara tendem a adscrever as Festas do Espírito Santo ao terreno da «religiosidade popular» são também ignorados pela legislação episcopal. A este respeito é elucidativo o confronto com a situação existente na Madeira. Aí, segundo Nelson Veríssimo, que transcreve alguns documentos alusivos, «as proibições das autoridades eclesiástica e civil mutilaram os festejos: regulamentações do Governo Civil limitaram a exteriorização da Festa, o arraial; provisões episcopais restringiram as insígnias das visitas domiciliárias do Espírito Santo, proibiram músicas e cantigas, baniram as cerimónias da coroação» (Veríssimo, 1988: 5). 
Por outro lado, mesmo circunscrevendo a sua acção a um número limitado de problemas, a Igreja tem consciência das dificuldades de implementação da sua própria legislação. Não é por acaso que uma parte importante das «censuras e leis» que passámos em revista é algo repetitiva. Por exemplo, parte das medidas tomadas em 1959 pelo Bispo Dom Manuel Afonso de Carvalho, reedita disposições anteriormente adoptadas pelas «Conferências do Clero de Angra» de 1884, que, por sua vez, repetem parte substancial da legislação contida na Circular de 1881 do Bispo Dom João Maria Pimentel. Neste documento, essa ineficácia da legislação episcopal é aliás explicitamente admitida: depois de se fazer alusão a providências anteriormente tomadas em relação aos abusos a que as Festas do Espírito Santo dariam lugar, constata-se não apenas a inoperância dessas providências como se refere o aparecimento de «novos abusos» (Circular, 1881a: 250). Esta dificuldade de implementação da legislação adoptada transparece também na mudança de linguagem que ocorre entre a Circular de 1881 e as "Resoluções das Conferências do Clero de Angra» de 1894. Enquanto que na primeira, se estipula a recusa da coroação para todos aqueles que infringirem as medidas aí definidas, na segunda, admite-se, de uma forma mais realista, que «o pároco deve sempre prestar as honras ao emblema do Divino Espírito Santo» (Resoluções..., 1895: 135) e que o único meio de combater os «abusos» é o «zelo religioso do pároco, manifestado em exortações paternais, feitas com prudência» (Id., ibid.: 130).

Quanto à actuação do clero ao nível local, há que levar em conta que os incidentes relatados são mais as exepções do que a regra. Em Santa Bárbara, por exemplo, a actuação dos dois párocos que se destacaram nas suas tentativas de combate ao culto do Espírito Santo não invalida um ambiente geral de coexistência entre povo e clero em torno dos Impérios. Não deixa aliás de ser significativo que esses dois párocos, como é referido localmente, «não tenham durado muito à frente da freguesia»: o primeiro viu-se forçado a abandoná-la ao fim de um ano e meio e o segundo deixou-a após cinco anos de ministério, não sem que no decurso desse período se tivesse criado um forte movimento de opinião contra ele. No caso de Santo Antão, é também significativo que a par do padre que referimos acima, as pessoas recordem igualmente um outro padre - oriundo da Terceira - que teve em relação às Festas do Espírito Santo uma actuação completamente distinta; não só era «muito amigo do Espírito Santo», estimulando o desenvolvimento dos festejos, como lhe é geralmente atribuída a iniciativa de introduzir, na estrutura das Festas propriamente ditas, o bodo de leite. Em 
Santa Bárbara, aliás, existe um caso muito similar a este: o de um padre que tendo paroquiado a freguesia durante cerca de duas dezenas de anos, ao ser-lhe atribuída uma nova paróquia em São Miguel, tomou a iniciativa de promover «Impérios à moda de Santa Maria» ${ }^{1}$. Isto é: se uma porção do clero local tem em relação às Festas do Espírito Santo uma atitude hostil e conflituosa, a maioria mantém uma postura mais consensual, registando-se mesmo casos, como acabámos de verificar, de padres que possuem uma certa empatia em relação ao ritual.

E à luz deste quadro que é possível entender em grande medida o baixo índice de implementação da legislação eclesiástica que referimos atrás. De facto, embora grande parte dessa legislação — em particular a que foi publicada no «Boletim do Governo Eclesiástico dos Açores» a partir da segunda metade do séc. XIX - se encontre ainda em vigor e seja do conhecimento geral dos párocos - que possuem nas suas paróquias uma colecção completa do referido Boletim - numerosas disposições são correntemente infringidas, perante a atitude contemporizadora do clero local. É o que se passa, em quase todo o arquipélago, com a articulação das alumiações, terços ou alvoradas com divertimentos e cantigas de carácter não-religioso. E o que se passa, em inúmeras freguesias do arquipélago, com a participação da Coroa em peditórios «pelas ruas e praças públicas», ou, ainda, com as disposições relativas à participação na coroação - ou nos cortejos que a rodeiam - de raparigas maiores de 12 anos. A própria existência de Irmandades do Espírito Santo, de acordo com o modelo estatutário adoptado em 1959, é também muito irregular: a par de freguesias onde estas foram efectivamente criadas, em muitas outras, nunca existiu nenhum esforço consistente nesse sentido. Assim, das cinco freguesias da ilha de Santa Maria, só duas delas - Santa Bárbara e Santo Espírito — possuíam, em 1987, irmandades desse tipo.

Finalmente, há ainda que considerar que alguns dos conflitos entre clero local e povo em torno das Festas do Espírito Santo que recenseámos atrás se inscrevem num quadro mais global onde avultam questões que têm antes do mais a ver com a esfera do político - em particular com questões de liderança local - e só secundariamente assumem a natureza de um conflito centrado na maior ou menor conformidade das Festas do Espírito Santo em relação à doutrina da Igreja. Mais uma vez, Santa Bárbara fornece um bom contexto de exemplificação. As iniciativas hostis relativamente aos Impérios tomadas pelo pároco que referimos em segundo lugar, inseriam-se de facto num contexto global de afrontamento com alguns dos líderes locais mais em evidência aquando da chegada do padre à freguesia. Visando o reforço da sua posi-

\footnotetext{
${ }^{1}$ Esses Impérios têm tido lugar na freguesia do Cabouco. O primeiro realizou-se em 1987 e contou com a participação de alguns especialistas rituais de Santa Bárbara: copeiro, foliões, mestra, etc...
} 
ção política, o padre moveu-lhes um combate surdo mas contínuo, ao mesmo tempo que procurava estimular o aparecimento de uma nova elite política local, colocada sob o seu controlo e favorável à sua acção. Ora alguns dos líderes que o padre hostilizava ocupavam posições de relevo na estrutura local dos Impérios, uma vez que exerciam com regularidade a função de copeiros (cf. a este respeito as pp. 43 e 44 do Capítulo 2). E sobretudo nesse quadro que se deixam compreender algumas das iniciativas tomadas pelo padre em relação aos Impérios. O que estava em causa não era tanto o culto do Espírito Santo e a sua maior ou menor conformidade em relação à «religião oficial», mas sobretudo uma estratégia de erosão de uma das bases em que assentava a autoridade dos líderes tradicionais. Não deixa a este respeito de ser significativo que simultaneamente a essas iniciativas hostis em relação aos Impérios, o referido padre tenha sido uma das figuras determinantes no relançamento do Império de São João (cf. Capítulo 2, p. 63). Quer dizer: a hostilidade contra os Impérios era menos uma hostilidade contra os Impérios em si, mas mais um instrumento, dotado de uma certa ambivalência, na luta pelo poder político ao nível local.

Algo similar parece ter-se passado em Santo Antão, nos anos 40. Comentando a acção do padre relativamente às Festas do Espírito Santo, as pessoas tendem de facto a sublinhar o modo como, por detrás dela, mais do que uma simples animosidade em relação aos festejos, se perfilava uma estratégia de afirmação da autoridade do padre em relação ao "partido do médico». E aliás elucidativo que o incidente que levou à interdição da estada das Coroas em casa dos mordomos tenha tido lugar em casa de um dos mais proeminentes activistas do «partido do médico».

\section{VI}

Uma parte da produção recente em Antropologia e História das Mentalidades acerca das práticas e crenças colocadas debaixo do epíteto de «religiosidade popular» tem encarado esta como uma espécie de «corpus» passivo invariavelmente submetido à repressão da «religião oficial».

Os dados respeitantes às Festas do Espírito Santo nos Açores mostram entretanto um quadro mais complexo. Sem que a animosidade e a repressão estejam ausentes, elas estão longe de resumir a atitude da Igreja em relação às Festas do Espírito Santo. Esta, tanto ao nível central como ao nível local, assume um tom predominantemente ambivalente, que oscila entre os pólos opostos da repressão - mas de um repressão algo limitada nos seus objectivos - e da tolerância.

Uma constatação similar foi feita, para o período da Contra Reforma, por Fernanda Enes. Depois de passar em revista um conjunto de proibições rela- 
tivas às Festas do Espírito Santo ${ }^{1}$, a autora sublinha que estas não põem em questão as bases mesmas do culto: «é estranho que a actuação da hierarquia nesta diocese, mesmo daqueles cujo espírito é nitidamente reformador, não enverede pela repressão dessas confrarias [do Espírito Santo]. Não há, aliás, qualquer citação às irmandades do Espírito Santo nas visitação pastorais analisadas, ao contrário do que acontece com outras irmandades e confrarias (...). Nenhum visitador proíbe as irmandades do Espírito Santo ou as suas festas» (Enes, 1985: 160). A autora interroga-se em seguida sobre as razões desta situação: «procurariam os reformadores controlar uma expressão da piedade popular, sem pôr em risco o decréscimo da devoção ao Espírito Santo? Ou o enraizamento e o papel de sociabilidade que elas desempenhavam no seio das comunidades não permitiam maior rigor repressivo? Ou, por outro lado, os visitadores não eram sensíveis às contradições que os ritos desta festa apresentavam em relação à pastoral tridentina?» (id., ibid.).

Formuladas a propósito do relacionamento entre a Igreja açoriana e as Festas do Espírito Santo no período da Contra Reforma, algumas das razões sugeridas por esta autora são susceptíveis de se aplicarem ao material que temos vindo a analisar. Assim, o fortíssimo enraizamento das Festas do Espírito Santo nas populações do arquipélago - tanto do ponto vista religioso, como do ponto de vista sociológico - parece ter funcionado ao longo dos tempos como um importante obstáculo a eventuais veleidades repressivas ou mesmo reformadoras, explicando designadamente o limitado alcance das «censuras e leis» emitidas pelas autoridades eclesiásticas. Quanto à insensibilidade do clero relativamente às contradições entre as Festas do Espírito Santo e certos aspectos da pastoral oficial da Igreja, ela é particularmente evidente ao nível local. De facto, maioritariamente de extracção local e de origem camponesa, «demasiado bem integrado na comunidade rural» (Vovelle, 1982: 150), educado num ambiente religioso e social marcado pela importância das Festas do Espírito Santo, o clero local açoriano parece particularmente mal colocado para se preocupar com as eventuais contradições entre as Festas do Espírito Santo e a «religião oficial».

\footnotetext{
1 Além de algumas das «censuras e leis» referidas por J. A. Pereira (Pereira, J. A., 1950), Fernanda Enes acrescenta a proibição decretada em 1678 por D. Fr. Lourenço de Castro, de se coroarem «imperadores antes de acabada a missa» ou de lhes permitir «a entrada na igreja com a cabeça coberta» (Enes, Fernanda, 1985: 161). Do Livro de Visitas de São Pedro Nordestinho (São Miguel) de 1743, a autora extrai ainda a seguinte menção: «tivemos notícia que quando os Imperadores do Espírito Santo se iam coroar à Igreja ou ermidas entravam com o chapéu na cabeça, e que depois de se entrar ao cânon da Missa estavam com as Coroas na cabeça, e que se lhe dava o Evangelho a beijar as quais coisas reprovamos como abusos introduzidos e não praticáveis; em cujos termos mandamos ao reverendo vigário sob pena de muito lhe entrarmos não consinta que os imperadores usem as referidas cerimónias» (id., ibid.).
} 
APÊNDICE B

AS FESTAS DO ESPÍRITO SANTO NO CONTINENTE

E NA MADEIRA 
Embora constituam hoje em dia um traço emblemático da cultura popular açoriana, as Festas do Espírito Santo existiram e nalgums lugares existem ainda em vários pontos do continente e da Madeira. O objectivo geral deste Apêndice é justamente o de fornecer uma ideia genérica da difusão do ritual nestas duas áreas, a partir da consulta da bibliografia disponível.

Comecemos pelo sul do país. No Algarve, J. A. Gascon (Gascon, 1921/22) refere a existência de Festas do Espírito Santo nas freguesia de Alte (concelho de Loulé), Bensafrim e Barão de São João (concelho de Lagos) e Marmelete (concelho de Monchique). Essas indicações reportam-se ao início deste século e num dos casos - na freguesia de Marmelete - o autor refere que os festejos tiveram pela última vez lugar em 1903. No vol. VIII da «Etnografia Portuguesa» de Leite de Vasconcelos, é também trancrita uma notícia de 1901 relativa às Festas do Espírito Santo nesta última freguesia (Vasconcelos, 1982: 322). Micaela Soares, por seu turno refere a existência de festejos similares em Tavira (Soares, 1983: 54).

No Alentejo, as indicações existentes dizem sobretudo respeito ao litoral. J. A. Gascon refere a existência de Festas do Espírito Santo na Bordeira, Odeceixe a Aljezur (concelho de Aljezur) onde teriam terminado no século passado, devido a proibição eclesiástica (1921/22: 275). Ainda no litoral alentejano, existe também uma descrição dos festejos em Santiago do Cacém, relativa ao ano de 1862 (Pires, 1908). Quanto ao Alentejo interior, as referências concentram-se fundamentalmente no distrito de Portalegre. Sabe-se que no séc. XVI, Portalegre, Marvão e Niza celebravam Festas do Espírito Santo (Azevedo, 1896) e para tempos mais recentes - finais do século passado, inícios deste século - além de uma referência suplementar a Niza (Moura, 1977: 58-59), existem menções relativas à Amieira (Sousa, Tude e Rasquilho, 1936: 430-433) e a Montalvão e Póvoas e Meada (Barata, 1969: 133-135).

$\mathrm{Na}$ Estremadura, os levantamentos mais completos são os realizados por Elisabeth Cabral e Luísa Nunes (Cabral, M. E. e Nunes. M. L., 1982/83) e por 
Micaela Soares (Soares, M., 1983) e incluem, além do caso emblemático de Alenquer ${ }^{1}$, Lisboa, Alcabideche e Cascais (concelho de Cascais), Sintra, Almoçageme, Colares, Mercês, Montelavar, São João das Lampas e Penedo (concelho de Sintra) e Torres Vedras. Francisco Câncio (1956: 125) menciona a realização de festejos em Arruda dos Vinhos e no vol. VIII da «Etnografia Portuguesa» de Leite de Vasconcelos é também feita referência à existência, em 1926, de Festas do Espírito Santo em Aldegalega da Merceana (Vasconcelos, 1982: 325 e 326). Com excepção deste caso e ainda de Alcabideche - onde os festejos continuavam a ter lugar no início do século ${ }^{2}$ - e do Penedo onde eles ainda se realizam actualmente - as restantes referências são anteriores ao séc. XIX e, nalguns casos, reportam-se mesmo a tempos mais recuados.

Mais a norte, possuímos indicações relativas às Festas do Espírito Santo em Óbidos (Anónimo, 1985: 140-141), Turquel (concelho de Alcobaça) (Ribeiro, José Diogo, 1908: 141-142), Reguengo do Fetal (concelho da Batalha) (António e Câmara, 1984), Vermoil (concelho de Pombal) (Vasconcelos, 1982: 326), Leiria (Soares, 1983: 19) e Eiras (Coimbra) (Campos, 1879; Pratt, 1899). Com excepção do Reguengo do Fetal e Vermoil — onde os elementos recolhidos se reportam respectivamente a 1984 e a 1926 - todas as outras referências são anteriores a finais do séc. XIX.

No Ribatejo, para além da Festa dos Tabuleiros de Tomar (cf. Ferreira, Fernando, 1978) são também várias as povoações, onde, em épocas diferentes, as Festas do Espírito Santo se teriam realizado. Ainda no concelho de Tomar, Francisco Ferreira refere a existência de festejos nas freguesias de Carregueiros (1978: 18 e 50), Paialvo (id.: 19 e 50), Casais, Pedreira, Linhaceira e Palhavã (id.: 50) e Francisco Câncio acrescenta a estas freguesias a de Junceira (1956: 283). Para outras áreas, o levantamento mais completo é o de Francisco Câncio e inclui Azinhaga do Ribatejo, Sardoal e Montalegre (Sardoal) (Câncio, 1956). Benavente (Azevedo, 1926: 81-121), Santarém (Soares, M., 1983: 87-88), Lamarosa da Olaia (concelho de Torres Novas) (Vasconcelos, 1982: 322-324), Meia Via (concelho de Torres Novas) (Laurentiaux, 1983: 88), Mouriscas (concelho de Abrantes) (Costa, Carlos e outros, s/d), Pedrogão Grande (Coelho, F. A., 1881: 73) e Mação (Chaves, L., 1945: 112) são outras das localidades para as quais se possuem referências às Festas do Espírito Santo.

\footnotetext{
${ }^{1}$ Como vimos, de acordo com as «narrativas de fundação» das Festas do Espírito Santo, teria sido em Alenquer que a Rainha Santa Isabel as instituiu. Posteriormente, existem testemunhos da realização das festividades para o séc. XVII (Brandão, 1672: 185). Refira-se, por curiosidade, que em 1945, por iniciativas da Junta da Província da Estremadura, teve lugar uma «recriação» dos festejos tal como eles teriam tido lugar no séc. XVII (cf. Câncio, 1956: 221-222).

${ }^{2}$ Segundo Elisabeth Cabral e Luísa Nunes, as Festas do Espírito Santo em Alcabideche mantiveram-se «em toda a sua pureza até inícios do presente século (1907 ou 1908)». Existem referências posteriores para 1926, 1929 e 1930 e ainda para 1979, mas o ritual caracterizava-se já por um certo declínio (Cabral. M.E. e Nunes, M.L., 1982/83: 823).
} 
Era entretanto na Beira Baixa que as Festas do Espírito Santo apresentavam uma maior densidade. A enumeração mais completa da geografia regional das Festas é da autoria de Jaime Lopes Dias (Dias, J., 1926, 69-80; 1942, $73-86 ; 1948,129-132 ; 1953,85-111 ; 1965,135-149)$ e menciona as seguintes localidades: no concelho de Penamacor, as povoações de Vale de Lobo, Benquerença, Meimoa, Meimão e Salgueiro; no concelho do Fundão, Capinha, Vale de Prazeres, Atalaia, Pero Viseu e outras povoações (para o concelho do Fundão, cf, também Cunha, J., 1892, 136-147); no Concelho da Sertã, o Castelo; no concelho de Idanha-a-Nova, Monsanto e Zebreira (para Monsanto, cf. também Buescu, 1961: 60-61); no concelho de Castelo Branco, Monforte da Beira e Tinalhas, e no da Covilhã, Teixoso e Casegas. Referências de carácter mais geral são ainda feitas aos concelhos de Belmonte e Proença-a-Nova. Luís Chaves acrescenta a esta lista Alpedrinha (Chaves, L., 1945: 110) e Paúl (id., ibid.: 103), ambas no concelho da Covilhã, Sarnadas (concelho de Vila Velha de Rodão) (id., ibid.: 112) e Açores (concelho de Celorico da Beira) (id., ibid.: 108) sendo esta última povoação mencionada também por Leite de Vasconcelos (1982: 326). No mesmo autor encontram-se ainda referências à realização de Festas do Espírito Santo na cidade da Covilhã (id., ibid.: 325), em Benquerença (concelho de Penacova) (id, ibid.: 317-320), em Telhado e Alcongosto (concelho do Fundão) (id., ibid.: 327), em Medelim (concelho de Idanha-a-Nova) (id., ibid.: 320) e ainda na Aldeia da Serra, Mourela e Velosa (concelho de Celorico da Beira) (id., ibid.: 326). Outras referências disponíveis reportam-se a Segura (concelho de Idanha-a-Nova) (Andrade, 1988: 331-336), Ladoeiro (concelho de Idanha-a-Nova) (Mesquita, 1984: 41) e Quadrazais (concelho do Sabugal) (Soares, 1983: 57-58). Esta listagem está entretanto longe de ser exaustiva: Lopes Dias afirma a este propósito que «poucas serão as povoações da Beira Baixa que não pratiquem com certo relevo, devoções do Espírito Santo» (Dias, J. L., 1965: 135). Constituindo a área do continente onde é mais densa a difusão das Festas do Espírito Santo, a Beira Baixa é também a área onde elas subsistiram até mais tarde. De facto, a maior parte das referências citadas situam-se no período compreendido entre 1920 e 1960. A partir desta data, ou posteriormente, parece entretanto ter-se acelerado o processo de declínio das Festas do Espírito Santo na Beira Baixa e, actualmente, em muitas das localidades mencionadas, elas deixaram já de se realizar.

Nesta distribuição regional das Festas do Espírito Santo é possível destacar alguns aspectos mais importantes. O primeiro prende-se com a ausência de testemunhos relativos ao norte do país ${ }^{1}$. Se tomarmos como ponto de par-

${ }^{1}$ É certo que em Leite de Vasconcelos se podem encontrar algumas referências a rituais relacionados com o Espírito Santo no norte do país: em Bougado (Santo Tirso) (Vasconcelos, 1982: 321) e em Bom Jesus de Matosinhos e Bom Jesus do Monte (id., ibid.: 324-325). Luís 
tida as grandes áreas geográficas em que, de acordo com Orlando Ribeiro (Ribeiro, O., 1963) se dividiria o território do continente - Norte Atlântico, Norte Transmontano e Sul - verifica-se que as Festas do Espírito Santo se concentram predominantemente no Sul, sendo escassa ou nula a sua representatividade tanto no Norte Atlântico como no Norte Transmontano (cf. mapa 20). É certo que na Beira, um certo número de povoações se situam já no Norte Atlântico. Deve entretanto ser realçado que elas se localizam predominantemente na linha de transição entre o Sul e o Norte Atlântico, uma zona ainda aberta a influências vindas do Sul. Podendo ser definidas como um traço cultural específico do Sul do país, as Festas do Espírito Santo não apresentam entretanto nessa área uma distribuição homogénea. A sua difusão é particularmente significativa em quatro regiões: a Beira Baixa, o Alto Ribatejo, a Estremadura e o Alentejo litoral e Algarve. Destas quatro regiões a mais importante é sem dúvida a Beira Baixa, devendo ainda salientar-se - apesar da excepção constituída pelo norte do distrito de Portalegre - a inexistência de referências significativas ao culto do Espírito Santo no Alentejo interior.

$\mathrm{Na}$ maior parte dos casos, as referências relativas às Festas do Espírito Santo nas várias localidades que acabámos de identificar, são relativamente breves e fragmentárias. Para um certo número de povoações, porém, é possível dispor de descrições mais desenvolvidas, susceptíveis de fornecer uma visão genérica da estrutura do ritual. E o que se passa com as Festas do Espírito Santo em Marmelete (Monchique), Santiago do Cacém, Alcabideche (Cascais), Penedo (Sintra), Reguengo do Fetal (Batalha), Eiras (Coimbra), Lamarosa da Olaia (Torres Novas), Tomar e nalgumas localidades da Beira Baixa.

Em Marmelete (Monchique), de acordo com as informações recolhidas por J. A. Gascon (Gascon, 1921/22), as Festas do Espírito Santo decorriam ao longo das sete semanas que se estendem do domingo de Páscoa ao domingo de Pentecostes. Os festejos eram assegurados, em cada uma das semanas, por um rei, uma rainha, um escrivão e vários mordomos e o seu acompanhamento e direcção musical estava a cargo de seis foliões, um dos quais tocava tambor. Apesar das designações dadas a alguns destes personagens, não existe entretanto qualquer referência à existência de uma Coroa do Espírito Santo. Nos domingos anteriores ao Pentecostes, a sequência dos festejos previa uma alvorada — entoada pelos foliões —, um almoço restrito — que tinha lugar em casa de um dos mordomos - e um peditório - que se realizava no termo da missa dominical. Neste peditório, o rei transportava consigo um bastão, no cimo do qual era espetada uma queijada, onde os vizinhos prendiam ou depositavam o seu contributo monetário; em troca, a rainha oferecia a cada

Chaves refere também a existência de uma solenidade colocada sob a evocação do Espírito Santo em Guimarães (Chaves, L., 1945: 102-103). Em todos estes casos, os elementos fornecidos sugerem entretanto tratar-se de celebrações sem relação explícita com os motivos principais que caracterizam as Festas do Espírito Santo propriamente ditas. 


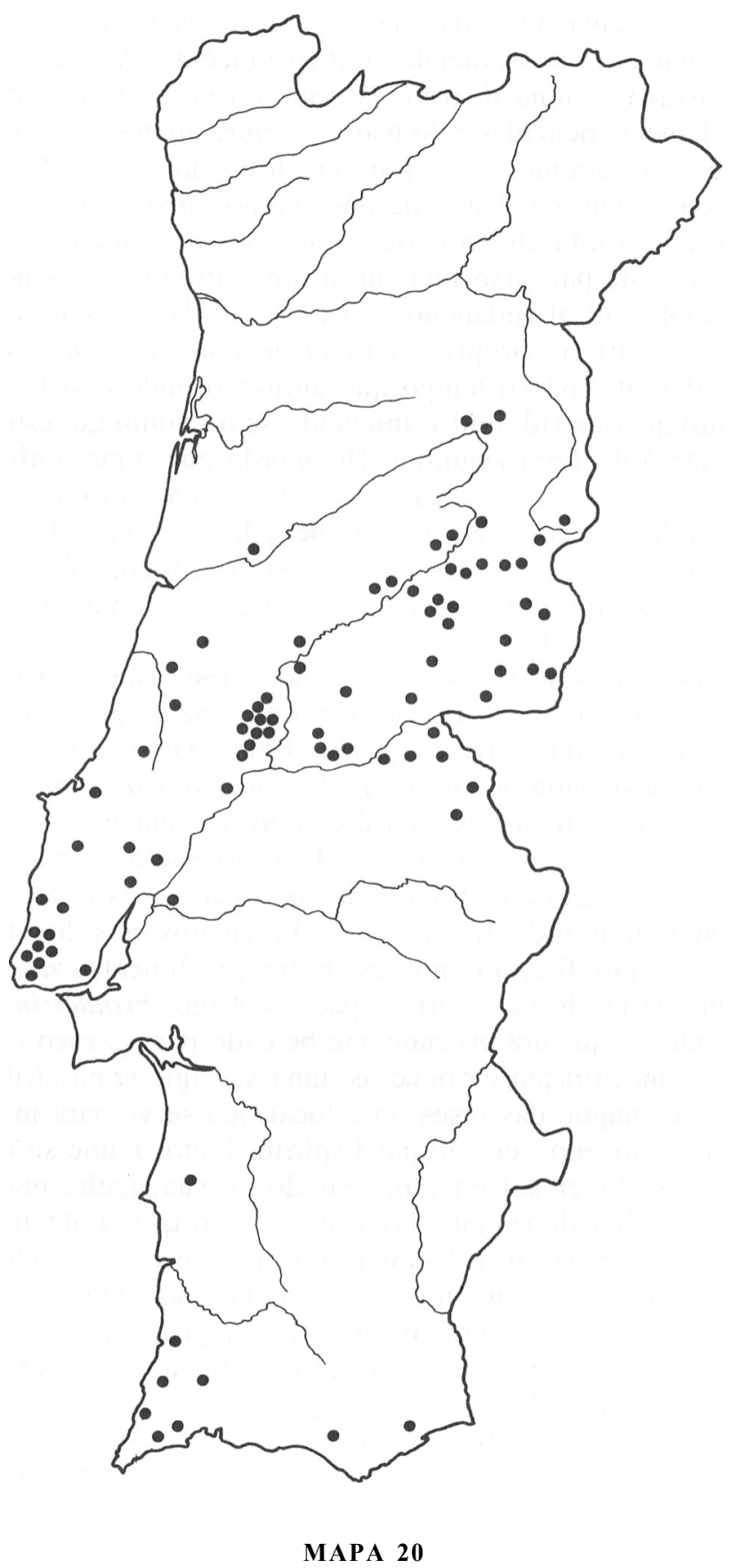

Distribuição das Festas do Espírito Santo no Continente 
um dos esmoleres uma queijada. Na semana do Pentecostes esta estrutura básica dos festejos era substancialmente enriquecida. Assim, na véspera de domingo, realizava-se uma distribuição porta-a-porta de esmolas de pão e carne - previamente benzidas pelo padre - entre algumas casas mais pobres da localidade. No domingo tinha por seu turno lugar o bodo, uma grande refeição colectiva que «constava de pão, vinho, arroz, carne e grãos, chegando a consumir trinta chibatos ou carneiros, dois ou três bois, cerca de noventa alqueires de pão, não falando já nos outros géneros nem no vinho que havia sempre em abundância» (Gascon, 1921/22: 283). Esta refeição tinha lugar num edifício próprio, a Casa do Espírito Santo onde «estava a mesa posta durante todo o tempo que durava o bodo e ia lá comer quem queria e quanto queria» (id. ibid.). Iniciando-se no domingo, este bodo podia prolongar-se até à $4 .^{\text {a }}$ feira seguinte. De acordo com uma notícia transcrita por Leite de Vasconcelos os gastos com o bodo foram, em 1901, de «135 alqueires de trigo em pão; 6.200 queijadas; 2 vacas; 35 carneiros; 25 galinhas; 4 arrobas de arroz; 3 alqueires de grão de bico; 25 arrobas de batatas; 45 kilos de toucinho; 31 almudes de vinho e 1 almude de aguardente» (Vasconcelos, 1982: 322).

Para Santiago do Cacém, possuímos uma descrição relativa ao ano de 1862, publicada no jornal «O Bejense» e reproduzida por Tomás Pires nas suas «Investigações Etnográficas» (Pires, 1908). De acordo com essa descrição, a Festa, designada por Bodo do Divino Espírito Santo, resultava de um voto individual e tinha lugar no domingo de Pentecostes. Além de um cortejo em que se integrava a Coroa do Espírito Santo - não existe entretanto qualquer referência à cerimónia da coroação - os festejos compreendiam ainda um conjunto de distribuições alimentares: aos doentes do hospital, aos presos e, por fim, aos pobres. Entre os alimentos distribuídos são referidos sopa, carne de vaca, arroz, pães de trigo, brindeirinhos e fartes. $\mathrm{O}$ abate do gado - que era previamente benzido pelo pároco — dava lugar a uma grande concentração de devotos, uma vez que eram atribuídas virtudes curativas ao sangue das reses: «no local que serve para matadouro das vacas destinadas ao bodo do Divino Espírito Santo, reúne-se quase toda a gente que tem qualquer sofrimento, munido da sua tigela, panela, púcaro, etc., etc., para encher do sangue das vacas e logo que o obtêm começam a untar o lugar onde existe o padecimento, e mesmo outros onde não existe, com o fim de não aparecer no sítio untado mal algum» (Pires, 1908: 71). As virtudes atribuídas aos alimentos oferecidos no quadro do bodo estendiamse também aos brindeirinhos, que eram colocados no trigo, para o preservar do gorgulho (id., ibid.: 72).

Em Alcabideche (Cascais) de acordo com os elementos referentes ao início do século recolhidos por Micaela Soares (Soares, M., 1983) e por Elisabeth Cabral e Luísa Nunes (Cabral, M. E. e Nunes, M. L., 1982/83), as Festas do Espírito Santo convergiam para o domingo de Pentecostes. À sua frente encontrava-se um grupo de quatrofesteiros que tinham designadamente a seu cargo 
a realização de um peditório com vista ao financiamento dos festejos. O personagem central das Festas era entretanto um imperador, que tinha como insígnia a Coroa do Espírito Santo e que era coadjuvado nos seus desempenhos cerimoniais por um condestável e por um camarista. Além da coroação do imperador, os festejos incluíam um bodo aos pobres, que «consistia na distribuição de uma tigela de arroz, com carne e sopas de pão, vinho e pão de trigo» (Soares, 1983: 42), uma distribuição generalizada de pão bento, e ainda uma distribuição mais restrita de pão de quilo bento junto dos vizinhos que tivessem oferecido «um alqueire de trigo ou mais» (id., ibid.) para as despesas da Festa.

No Penedo (Sintra), as Festas do Espírito Santo subsistiram até aos nossos dias, ainda que com algumas transformações relativas ao modelo tradicional $^{1}$. Convergindo para o domingo de Pentecostes, os festejos têm à sua frente uma comissão composta por um número variável de festeiros. Esta, além de superintender os festejos, tem a seu cargo a realização, algum tempo antes da Festa, de um peditório pelos lugares das redondezas. O personagem central dos festejos é entretanto o imperador. Esse cargo era exercido, até meados do século passado, por um adulto, ocasião em que passou a ser desempenhado por uma criança de cinco a dez anos de idade, em cumprimento de uma promessa feita por pais ou familiares. O imperador enverga um traje próprio, constituído por um fato de veludo vermelho, um chapéu do mesmo tecido, e meias e camisa branca, e tem como insígnias uma Coroa do Espírito Santo, um ceptro e uma espada. Coadjuvam-no nos seus desempenhos cerimoniais um condestável e um porta estandarte. O primeiro possui insígnias semelhantes às do imperador enquanto o segundo tem a seu cargo o transporte de um estandarte do Espírito Santo. Estes dois cargos são geralmente desempenhados pelo imperador do ano seguinte e pelo imperador do ano transacto. Os festejos iniciam-se na véspera do domingo de Pentecostes, com o abate de uma rês. Tradicionalmente, esta era passeada em cortejo pelas ruas da povoação e devia ainda efectuar duas ou três voltas rituais ao redor da capela local. Desde aos anos 40/50 o abate da rês passou entretanto a ser antecedido de uma tourada à corda. No domingo tem lugar a coroação, que se realiza antes do início da missa, à porta da Capela e que, além do imperador do ano, incide também sobre o imperador do ano seguinte ou condestável. Ao fim da tarde, realiza-se por seu turno o bodo, presidido pelo imperador, pelo condestável e pelo porta estandarte. No seu decurso é servida a carne do boi abatida na véspera, cozinhada de forma variável de ano para ano. Além de algumas dezenas de pobres, participam também no bodo um certo número de

\footnotetext{
${ }^{1}$ Para uma apresentação mais detalhada do modelo tradicional das Festas do Espírito Santo no Penedo, cf. Keil, 1917. A estrutura actual dos festejos foi objecto de dois estudos monográficos, de Elisabeth Cabral e Luísa Nunes (Cabral, M.E. e Nunes, M.L., 1982/83) e de Micaela Soares (Soares, 1983).
} 
devotos que fizeram a promessa de se sentar com eles na mesma mesa. No decurso do bodo, muitas pessoas percorrem as mesas, distribuindo entre os presentes uma certa quantidade de dinheiro, em cumprimento de promessas.

No Reguengo do Fetal (Batalha) - de acordo com a descrição de Ana Maria António e Maria da Luz Câmara (1984) - as Festas do Espírito Santo realizam-se no domingo de Pentecostes e têm à sua frente um imperador, que assume o cargo em resultado de uma promessa específica nesse sentido. Os festejos envolvem ainda a participação de uma parte importante da população da freguesia, que se associa a eles mediante a oferta de uma grande número de pães. Os festejos iniciam-se com a coroação do imperador. A cerimónia, presidida pelo padre, realiza-se no largo central da localidade e, uma vez terminada, forma-se um cortejo que, depois de entrar na igreja paroquial, se dirige para a capela de Nossa Senhora do Fetal. Nesse cortejo, além do imperador, seus familiares e convidados, integram-se também as pessoas que ofereceram pães para a Festa, sendo estes transportados em cestos especialmente decorados para o efeito. Depois da missa, o padre procede à benção do pão e segue-se um almoço em casa do imperador - ou noutro recinto apropriado - destinado a familiares e convidados deste, em número que chega a ser de duas centenas. Entretanto, junto à capela, decorre um arraial e, ao fim da tarde, tem lugar a distribuição de pães. Finda esta, forma-se um novo cortejo que se dirige da capela para a igreja paroquial, onde tem lugar uma segunda coroação do imperador. O termo dos festejos é assinalado pela realização de um jantar em casa do imperador, organizado em moldes similares ao almoço.

Em Eiras (Coimbra), de acordo com as descrições de Aires de Campos (Campos, 1879) e Alfredo Pratt (Pratt, 1899) relativas a inícios do séc. XIX, as Festas do Espírito Santo parecem ter tido origem num voto popular relacionado com uma epidemia de peste e realizavam-se no domingo de Páscoa e no domingo de Pentecostes. As insígnias da Festa eram constituídas por uma Coroa, um estandarte e um sabre. À sua frente encontrava-se um imperador, escolhido pela Câmara do concelho que lhe entregava na mesma ocasião vinte e seis mil réis em dinheiro, cinquenta alqueires de trigo e oito almudes de vinho como contributo para as despesas dos festejos. Para estas contribuíam ainda os lavradores locais, com ofertas em géneros. Coadjuvado por dois pagens e dois criados, o imperador era coroado pelo padre na igreja local e, acompanhado de uma numerosa comitiva, que seguia a cavalo, devia visitar sucessivamente o convento de Celas - onde se realizava uma nova coroação - e o lugar de Santo António dos Olivais. Os festejos compreendiam ainda um conjunto de sequências de características alimentares, entre as quais um jantar, distribuições de esmolas de pão, vinho, fartes, bolos e tremoços e ofertas de carne, pão, lacticínios e doces entre os lavradores que haviam contribuído para as despesas dos festejos.

$\mathrm{Na}$ Lamarosa da Olaia (Torres Novas), de acordo com uma notícia relativa ao ano de 1904 reproduzida por Leite de Vasconcelos (Vasconcelos, 1982: 322 a 324), as Festas do Espírito Santo convergiam para o domingo de Pentecostes 
e tinham à sua frente um juiz da festa. Na 5. ${ }^{a}$ feira anterior ao Pentecostes realizava-se a chamada festa dos tabuleiros: um cortejo formado exclusivamente por raparigas procedia à entrega cerimonial dos pães oferecidos peloa vizinhos na casa do juiz dafesta. $6 .^{\mathrm{a}}$ feira era abatida uma rês, cuja carne era depois distribuída pelos vizinhos que haviam contribuído para a festa. No sábado, tinha lugar o bodo: um cortejo percorria as ruas da povoação, distribuindo pão e vinho em todas as casas. No domingo, por fim, as cerimónias tinham características exclusivamente religiosas: o juiz, acompanhado da Coroa do Espírito Santo, assistia à missa, no termo da qual a Coroa era entregue ao juiz do ano seguinte. Não existe porém qualquer referência à coroação.

Em Tomar (Ferreira, Fernando, 1978), a Festa dos Tabuleiros - que conheceu, no decurso dos anos 50/ 60 profundas modificações, ligadas sobretudo ao seu aproveitamento para fins turísticos - desenrolava-se tradicionalmente ao longo do período que medeia entre o domingo de Páscoa e o domingo de Pentecostes. No domingo de Páscoa realizava-se o Cortejo das Coroas, que eram levadas procissionalmente à igreja. Este Cortejo repetia-se nos domingos seguintes. Na véspera de domingo de Pentecostes tinha por seu turno lugar a Procissão dos Tabuleiros, no decurso da qual eram reunidas as ofertas em pão oferecidas pelos devotos. Estes pães. bem como a carne de um certo número de reses abatidas para o efeito eram benzidos, sendo depois objecto, em domingo de Pentecostes, de uma distribuição pública conhecida pela designação de bodo. Embora não existam referências seguras à existência de coroação, esta parecia ser de norma nas freguesias rurais do concelho, onde a sequência das Festas possuía inúmeros pontos de contacto com aquela que acabámos de sintetizar.

Na Beira Baixa, de acordo com as descrições de Jaime Lopes Dias as Festas do Espírito Santo estendiam-se ao longo do período de sete semanas que medeia entre o domingo de Páscoa e o domingo de Pentecostes. A sua frente encontrava-se uma folia ou confraria - as duas expressões são igualmente utilizadas por Jaime Lopes Dias - integrada por um grupo de mordomos e outros personagens, em número e com designações variáveis de localidade para localidade, que assumiam entre si o encargo da promoção dos festejos. Entre esses personagens contavam-se em certos casos os responsáveis pela direcção e acompanhamento musical dos festejos, que recebiam também designações variadas consoante as localidades. Em cada um dos domingos em que decorriam os festejos, a Coroa e outras insígnias do Espírito Santo eram conduzidas em cortejo à igreja a hora da missa; não se realizava entretanto qualquer coroação. No fim da missa, tinha lugar uma refeição cerimonial restrita aos membros àz folia ou confraria e aos seus convidados, cuja responsabilidade recaía à vez sobre um dos seus membros. Essa refeição constava de alimentos cerimoniais variáveis de localidade para localidade e obedecia em geral a uma etiqueta própria minuciosamente regulamentada. Antes dos vários alimentos serem servidos eram entoadas quadras alusivas, os vários membros da confraria trocavam entre si saudações recíprocas e, em certos casos, eram mesmo aplicadas multas a quem desrespeitasse o cerimonial estipulado. 
No interior deste quadro genérico que esboçámos, é possível indicar algumas variações mais significativas. Essas variações dizem respeito, em primeiro lugar à composição e designações da confraria. Numa descrição genérica dos festejos contida no vol. I da «Etnografia da Beira» (1926: 6980), Lopes Dias refere um caso em que ela era composta por um rei, um pagem, um alferes, dois mordomos e seis fidalgos. Estes últimos tinham a seu cargo o acompanhamento e direcção musical dos festejos. Na Zebreira (Idanha-a-Nova) a folia era composta por um total de dezasseis membros: um juiz, um alferes, um escrivão, uma tesoureira, e doze mordomos. Estes cargos, com excepção da tesoureira, eram geralmente desempenhados por rapazes novos (Dias, J. L., 1953: 87). Em Monsanto (Idanha-a-Nova) os festejos estavam a cargo de um conjunto de mordomos, que, por promessa, encabeçavam a Festa em cada um dos domingos (Buescu, 1961: 60). Na Capinha (Fundão), a folia era composta por um rei, um alferes um pagem e quatro fidalgos (Cunha, J. G., 1892: 138). Na Atalaia (Fundão) faziam parte dela um alferes - que devia ser um rapaz noivo - um tesoureiro, um juiz, oito mordomos, além de um tambor (id. ibid.: 143). Em Pero Viseu (Fundão) integravam a folia um rei, um alferes, e três foliões propriamente ditos, para além de um número não especificado de mordomos (id., ibid.: 145). Em Teixoso (Covilhã), a folia era composta por sete membros escolhidos entre os homens que tivessem contraído casamento no ano transacto e compreendia um rei, um alferes, um procurador, um juiz, um escrivão e dois mordomos (Dias, J. L., 1965: 147 e 148). Em Monforte da Beira (Castelo Branco), a folia integrava também sete membros; um juiz, um alferes - este obrigatoriamente solteiro - um secretário — também designado por rei - um coroeiro - cargo desempenhado por uma criança - um tesoureiro e dois mordomos; cada um destes sete elementos era escolhido numa das sete áreas em que, para o efeito, a freguesia se dividia (Dias, J. L., 1953: 109). Por fim, em Benquerença (Penacova) a designação de folia era reservada aos seis indivíduos que tinham a seu cargo a direcção e acompanhamento musical dos festejos, três dos quais eram designados também por duques e os restantes três por marqueses. «Agregados a eles há uma companhia de sete indivíduos eleitos anualmente pelos outro sete do ano anterior e que se denominam: rei, alferes, pagem, juiz, tesoureiro e mordomos (dois)» (Vasconcelos, 1982: 318).

O conteúdo das refeições que têm lugar em cada um dos domingos do período consagrado à realização dos festejos é também variável. Lopes Dias refere como ementa mais generalizada «as sopas, arroz, ensopado, prato desconhecido (contem iguaria que vem para a mesa escondida) e arroz doce» (Dias, J. L., 1926: 76). Na Zebreira, por seu turno, são servidos tremoços, filhos, mel e vinho (id., 1953: 90). E em Benquerença «o jantar consta de sopa, cozido (carne) e arroz, carne guisada, arroz de lebre e de coelho e carne assada, vinho à vontade, fruta e arroz doce ou letria» e ainda «um queijo fresco, sem sal, polvilhado de açúcar» (Vasconcelos, 1982: 319). 
No arquipélago da Madeira, as Festas do Espírito Santo, tal como nos Açores, remontam aos tempos do povoamento, mas, embora se mantenham ainda em muitas freguesias, parecem encontrar-se em processo de declínio. Já em 1921, os autores do «Elucidário Madeirense» assinalavam que «os grandes festejos que se realizavam outrora no domingo do Espírito Santo, estão muito reduzidos» (Silva/Meneses, 1984: 421). Escrevendo em 1985 sobre o mesmo tema, Nelson Veríssimo, depois de referir que «ainda hoje, em muitas freguesias da Madeira se continua a proceder a estes festejos», acrescentava de imediato que «este costume está a perder o seu cunho original e tende a desaparecer» (Veríssimo, 1985: 9).

As descrições disponíveis (cf. entre outros Silva/Meneses, 1984, 412 e 413; Pereira, E., 1967, 1091 a 1094; Sarmento, 1951, 91 a 96; Veríssimo, 1985 e 1988) sugerem a existência de um modelo relativamente uniforme dos festejos.

Estendendo-se ao longo do período que medeia entre o domingo de Páscoa e o domingo de Pentecostes, as Festas do Espírito Santo têm à sua frente um conjunto de quatro mordomos. Nos seus desempenhos cerimoniais, estes mordomos vestem uma opa de seda vermelha e cada um deles transporta uma das insígnias da Festa: a Coroa, o ceptro, um pendão e uma bandeira do Espírito Santo. O mordomo a quem compete o transporte do ceptro é conhecido pela designação de imperador «por razão duma antiga cerimónia de coroação já banida com que era distinguido» (Pereira, E., 1957: 1093)Estes mordomos têm a seu cargo a visita do Espirito Santo que decorre em cada um dos domingos que antecedem o domingo de Pentecostes. «Acompanhados de crianças de dez a doze anos [as chamadas saloias] com antigos trajos campónios, ornados de prendas, e de tocadores de machete, rabeca, viola e rajão» (id., ibid.) os mordomos visitam sucessivamente todas as casas da freguesia, onde dão as insígnias a beijar aos elementos da casa e recolhem também «esmolas em dinheiro e produtos da terra para ajuda de festa» (id., ibid.: 1091). Estas visitas são rodeadas de uma certa cerimonialização. As casas são decoradas «com flores e verdura» (Veríssimo, 1985: 13) e é preparada uma mesa com «um jarro de vinho e um prato de doces» (id., ibid.) para os mordomos e cantadeiras. Os momentos mais significativos da visita a cada casa são assinalados através de cantigas - de saudação, de agradecimento, etc... - entoadas pelas cantadeiras ${ }^{2}$. No final da visita a cada um dos lugares da freguesia «as pessoas juntavam-se na berma dos caminhos para se despedirem das insígnias» (id., ibid.).

\footnotetext{
${ }^{1}$ No Porto Santo, os mordomos eram em número de dezoito e, além do imperador é ainda referida a existência de um pagem, dois camaristas e um marechal (Pereira, E., 1957: 1092).

${ }^{2}$ Vale a pena sublinhar as similitudes entre estas visitas do Espírito Santo e o compasso pascal tal como este se realiza tradicionalmente em muitos pontos do país. Cf. a este respeito Veiga de Oliveira, 1984g.
} 
O domingo de Pentecostes representa o ponto culminante dos festejos. Na véspera ou no próprio dia, organiza-se um cortejo, encabeçado pelos mordomos, que transporta para a copa - «um barracão de verdura e flores improvisado no adro» da igreja (Pereira, E., 1957: 1093) — os produtos agrícolas e os alimentos - pão, carne, etc... - confeccionados a partir do produto das esmolas das visitas. No domingo, depois da missa, uma parte desses alimentos, depois de benzida pelo pároco é distribuída na copa entre um certo número - geralmente doze - de pobres da freguesia. Segundo Nelson Veríssimo «a cada pobre era destinada uma posta de carne, $1 \mathrm{~kg}$ de arroz, $1 \mathrm{~kg}$ de massa, 1 pão de quilo, frutas e um prato com doces» (Veríssimo, 1985: 16). Em certas freguesias, esses pobres são também convidados para uma refeição em casa do imperador, que consta de sopa de couve, caldo de massa, arroz com carne assada de vaca ou porco, doces e fruta (id., ibid.). Para além destas duas prestações alimentares, a sequência dos festejos é ainda integrada por uma distribuição porta-a-porta de pão bento «pelos casais da freguesia que contribuíram com esmola para a festa» (id., ibid.: 17). Esta distribuição tem lugar na segunda feira do Espírito Santo ou ao longo de toda a semana que se segue ao domingo de Pentecostes. Em cada casa, «o pão bento era colocado num prato, no centro da mesa. Então a família (todos os membros do agregado doméstico) comia uma parte do pão. O pão era partido pelo homem, chefe de família, e era por ele distribuído aos mais velhos (...) e depois à mulher e aos filhos». No fim, entretanto, devia «sobrar, por obrigação, um pedaço de pão» que «era religiosamente guardado e merecia o culto e a veneração da família. A ele eram atribuídos poderes miraculosos»(id., ibid.). 


\section{BIBLIOGRAFIA}




\section{I - FONTES MANUSCRITAS E JORNAIS}

O BALUARTE, Vila do Porto.

CADASTRO PREDIAL RÚSTICO DAFREGUESIA DE SANTA BÁRBARA, Repartição de Finanças de Vila do Porto.

O ECO MARIENSE, Vila do Porto.

O INSULANO, Topo.

LIVROS PAROQUIAIS DE REGISTOS DE CASAMENTOS DE NOSSA SENHORA

DA PIEDADE (PICO), 1946 a 1987.

LIVROS PAROQUIAIS DE REGISTOS DE CASAMENTOS DE SANTA BÁRBARA (SANTA MARIA), 1917 a 1982.

LIVROS DE REGISTOS DE EMIGRANTES DA CÂMARA MUNICPAL DE VILA DO PORTO 1962 a 1987.

RENOVAR, Boletim Inter-Paroquial da Ilha de Santa Maria, Vila do Porto.

REQUERIMENTOS DIRIGIDOS À CÂMARA MUNICPAL DE VILA DO PORTO solicitando autorização para o abate de gado fora do matadouro por ocasião dos Impérios, 1964 a 1987.

O VELENSE, Velas.

\section{II - OBRAS IMPRESSAS}

ADLER, Alfred, 1982 La Mort est le Masque du Roi. La Royauté Sacrée des Moundang du Tchad. Paris: Payot.

ALMEIDA, Gabriel D', 1889, Fastos Açorianos. Lisboa: Companhia Nacional Editora.

ALMEIDA, Onésimo Teotónio de, 1980, «A Profile of the Azorean». Macedo Donaldo (ed.), Issues in Portuguese Bilingual Education, Cambridge, 
Mass., National Assessment for Portuguese Bilingual/ Bicultural Education: 113-164.

-, 1989, Açores, Açorianos, Açorianidade - Um Espaço Cultural. Ponta Delgada: Signo.

ANDRADE, Mário Marques de, 1988 (1946), Subsídios para a Monografia de Segura. Tomar: edição do autor.

ANÓNIMO, 1985 (ms. século xix), Memórias Históricas e Diferentes Apontamentos, acerca das Antiguidades de Óbidos (leitura, apresentação e notas de João Trindade). Lisboa: Imprensa Nacional-Casa da Moeda/ Câmara Municipal de Óbidos.

ANTÓNIO, Ana Maria e câmara, Maria da Luz, 1984, Festas do Espírito Santo numa Aldeia da Beira Litoral: Reguengo do Fetal (trabalho dactilografado). Lisboa: Universidade Nova de Lisboa/ Faculdade de Ciências Sociais e Humanas.

ATAÍDE, Luís Bernardo Leite de, 1920, «Folklore do Concelho das Furnas». Revista Micaelense, ano 3, $\mathrm{n}^{\circ}$ 2: 766-783.

—, 1947, «Alguns Usos e Superstições Relacionados com a Morte». A Ilha, n. $^{\text {os }} 785$ e 786 .

—, 1973 (1918), «Teatros do Espírito Santo». Etnografia, Arte e Vida dos Açores, vol. I: 250-256.

AVELAR, José Cândido da Silveira, 1902, A Ilha de São Jorge (Açores). Apontamentos para a sua História. Horta: Typ. Minerva Insulana.

AZEVEDO, Alvaro Rodrigues de, 1926 (1924), Benavente. Estudo Histórico-Descritivo. Lisboa: Minerva Lisbonense.

AZEVEDO, Pedro D', 1896, «As Festas dos Imperadores». Revista Lusitana, vol. IV: $134-142$.

BAKHTINE, Mikhail, 1970, L'Oeuvre de François Rabelais et la Culture Populaire au Moyen Age et sous la Renaissance (trad. de Andrée Robel). Paris: Gallimard.

BARATA, José Pedro Martins, 1969, «Tradições Religiosas em Montalvão e em Póvoas e Meada». Etnos, vol. VI: 49-157.

BENEDICT, Ruth, 1935, Patterns of Culture. Londres: George Routledge \& Sons.

BENVENISTE, Emile, 1969, Le Vocabulaire des Institutions Indo-Européennes, Vol. I: Economie, Parenté, Société. Paris: Minuit.

BERANGER, Dom Prosper, 1949, L Année Liturgique, Vol. II: Séptuagesime, Carême et Passion. Paris, Tournai, Roma: Desclée et Cie.

BETTENCOURT, Alberto, 1986/8, Características da Emigração Açoriana. Do Arquipélago à Pequena Comunidade, Motivações Objectivas e Subjectivas (tese dactilografada). Lisboa: Universidade Nova de Lisboa/Faculdade de Ciências Sociais e Humanas.

—, 1988, "As Mudas - Movimentos Anuais das Populações da Zona do Topo na Ilha de São Jorge». Atlântida (Ciências Sociais), vol. II: 183-200 . 
BLOCH, Maurice, 1987, «The Ritual of the Royal Bath in Madagascar: the Dissolution of Death, Birth and Fertility in Authority». Cannadine, D. e Price, S. (eds.), Rituals of Royalty. Power and Ceremonial in Traditional Societies, Cambridge, Cambridge University Press: 271-297.

BLOCH, Maurice e Parry, Jonathan, 1982, "Introduction: Death and the Regeneration of Life». Bloch, M. e Parry, J. (eds.), Death and the Regeneration of Life, Cambridge, Cambridge University Press: 1-44.

BOAS, Franz, 1966, Kwakiutkl Ethnography (edited and abridged by Helen Codere). Chicago: The University of Chicago Press.

BOSSEVAIN, Jeremy, 1965, Saints and Fireworks. Religion and Politics in Rural Malta. Londres: Athlone Press.

_, 1977, «When the Saints Go Marching Out: Reflections on the Decline of Patronage in Malta». Gellner, E. e Waterbury, J. (eds.), Patrons and Clients in Mediterranean Societies, Londres, Duckworth: 81-96.

-, 1978 (1974), Friends of Friends. Networks, Manipulators and Coalitions. Oxford: Basil Blackwell.

—, 1992, «Introduction». Boissevain, J. (ed), Revitalizing European Ritual. Londres, Routledge: 1-19.

BONNAIN, Rolande, 1981, «Une Economie de Sociabilité; Entraide, Echanges et Relations de Voisinage dans un Village Pyrénéen». Augustin, G. e Bonnain, R., Les Baronnies des Pyrénées. Anthropologie et Histoire, Permanences et Changements. Vol. I.. ${ }^{a}$ Maison, Mode de Vie, Société, Paris, EHESS: 169-193.

—, 1981b, «Le Pele-Porc dans les Baronnies». Augustin, G. e Bonnain, R., Les Baronnies des Pyrénées Anthropologie et Histoire, Permanences et Changements. Vol. I: Maison, Mode de Vie, Société, Paris, EHESS: 195-218 .

BRANDÃO, Fr. Francisco, 1672, Sexta Parte. Monarchia Lusitana. Lisboa.

BRANDÃO, Raul, 1926, As Ilhas Desconhecidas. Notas e Paisagens. Lisboa: Livraria Aillaud e Bertrand.

BRANDES, Stanley, 1973, «Wedding Ritual and Social Structure in a Castillian Peasant Village». Anthropological Quarterly, vol. 46: 65-74.

-, 1988, Power and Persuation. Fiestas and Social Control in Rural Mexico. Filadélfia: University of Pennsylvania Press.

BRETTEL, Caroline, 1983, «Emigração, a Igreja e a Festa Religiosa do Norte de Portugal: Estudo de um Caso». Studium Generale/Estudos Contemporâneos, $\mathrm{n}^{\circ} \quad$ 5: 175-204.

BUESCU, María Leonor C., 1961, Monsanto - Etnografia e Linguagem. Lisboa, Centro de Estudos Filológicos.

CABRAL, Júlio, 1903, «Festejos do Espirito Santo». Album Açoriano: 265$-269$.

CABRAL, M. Elisabeth e Nunes, M. Luísa, 1982/83, «Contributo para o Estudo das Festividades em Louvor do Divino Espírito Santo no Lugar do Penedo (Colares-Sintra)». Sintria, vols. I/II: 803-1028. 
CABRAL, Pe. Joaquim Chaves, 1921, «Festas do Espírito Santo na Ilha de Santa Maria». Arquivo dos Açores, vol. XIV: 61-78.

CAILLER-BOISVERT, Colette, 1968, «Remarques sur le Systéme de Parenté et sur la Famille au Portugal». L'Homme, vol. VII: 87-103.

CÃMARA, J. M. Bettencourt da, 1984, Para a Sociologia da Música Tradicional dos Açores. Lisboa: Instituto de Cultura e Língua Portuguesa.

CAMPOS, J. C. Ayres de, 1879, «Apontamentos Históricos de Coimbra. O Imperador de Eiras». Portugal Pittoresco, vol. I: 138-142.

CANCIAN, Frank, 1965, Economics and Prestige in a Maya Community. The Religious Cargo System in Zinacantan. Stanford, California: Stanford University Press.

CÃNCIO, Francisco, 1956, Notas dum Ribatejano. Lisboa: Impr. Barreiro.

CANTO E CASTRO, Francisco, 1946, «Memoria Histórica das Festas do Divino Espirito Santo na Ilha de São Jorge». Insulana, vol. III: 495-502.

CARDOSO, Carlos Lopes, 1982, Do Gordo Entrudo à Páscoa das Flores. Três Aproximações Etnográficas. Lisboa: Instituto Português do Patrimonio Cultural/ Departamento de Etnologia.

CARO BAROJA, Júlio, 1979a (1965), El Carnaval (Análisis Historico-Cultural). Madrid: Taurus.

- 1979b La Estación del Amor (Fiestas Populares de Mayo a San Juan). Madrid: Taurus.

CHAVES, Francisco A., 1904, «Festas do Espirito Santo no Açores». Arquivo dos Açores, vol. XIII: 11-35.

CHAVES, Luís, 1945, Folclore Religioso. Porto: Portucalense Editora.

CHRISTIAN Jr., William A.,1978 (1972), Religiosidad Popular. Estudios Antropologicos en un Valle Español (trad. de Enrique Luque Baena). Madrid: Tecnos.

"Circular aos Mtos. Rvdos. Parochos», 1881a, Boletim do Governo Eclesiástico dos Açores, T. IV: 249-243.

-, 1881b, Boletim do Governo Eclesiástico dos Açores, T. IV: 274-275.

COELHO, F. Adolfo, 1881, «Materiaes para o Estudo das Festas, Crenças e Costumes Populares Portugueses». Revista d'Ethnologia e Glottologia, vols. II/III: 49-108.

COELHO, Manuel de Avila, 1961, «A Freguesia de Nosssa Senhora da Piedade na Ilha do Pico». Boletim do Núcleo Cultural da Horta, vol. II: 291-377.

CONSTÃNCIA, João de Medeiros, 1982, «A Ilha de Santa Maria. Evolução dos Principais Aspectos da sua Paisagem Humanizada (sécs. xv a xix). Arquipélago (Série Ciências Humanas), n. ${ }^{\circ}$ IV: 225-244.

«Coroações», 1924, Boletim Eclesiástico dos Açores, T. XXVI»: 272-273.

CORTES-RODRIGUES, Armando, 1924, «As Festas do Espirito Santo na Ilha de São Miguel». Arquivo dos Açores, vol. XIV: 299-311.

—, 1942/45, «Cantar às Almas». Açoreana, vol. III: 17-35.

-, 1982, Adagiário Popular Açoriano, I vol. Angra do Heroísmo: Secretaria Regional da Cultura. 
CORTESÃO, Jaime, 1980 (s/d), Os Descobrimentos Portugueses, vol. I. Lisboa: Livros Horizonte.

COSTA, Antonieta, 1987, Festas em Louvor do Divino Espírito Santo, Abordagem Socio-Cultural. S/ indicação de local de edição: ed. da autora.

COSTA, C., LOUREnÇO, L., ROBAlO, M. e ROLÃO, B., s/d, A Festa do Espírito Santo em Mouriscas (trabalho dactilografado). Lisboa: Universidade Nova de Lisboa/ Faculdade de Ciências Sociais e Humanas.

COSTA, Carreiro da, 1957, «As Festas do Espírito Santo nos Açores. Breve Notícia a seu respeito em cada uma das Ilhas do Arquipélago». Insulana, vol. XIII: $5-54$

-, 1989, Etnologia dos Açores, vol. I (organização, prefácio e notas de Rui Sousa Martins). Lagoa: Câmara Municipal da Lagoa.

COSTA, José Maria da, 1913, «O Espírito Santo nos Açores». Revista do Minho, vol. XV: 26-27.

CRUCES, Francisco e DIAZ DE RADA, Angel, 1992, «Public Celebrations in a Spanish Valley», Boissevain, J. (ed.). Revitalizing European Ritual, Londres, Routledge: 62-79.

CUNHA, Dom Rodrigo, 1642, Historia Ecclesiastica da Igreja de Lisboa. I. Lisboa.

CUNHA, José Germano, 1892, Apontamentos para a História do Concelho do Fundão. Lisboa: Tip. Minerva Central.

CUNHA, P. Manuel da, 1981 (1906), «Festas do Espírito Santo na Ilha de São Jorge». Notas Históricas. Vol. I, Estudos sobre o Concelho da Calheta (São Jorge), Ponta Delgada, Universidade dos Açores: 423-461.

CUTILEIRO, José, 1977 (1971), Ricos e Pobres no Alentejo. Lisboa: Sá da Costa.

DEHOUVE, Daniéle, 1974, Corvées des Saints et Luttes des Marchands. Paris: Klincksiek.

DIAS, A. Jorge, 1990a (1960), «Tentamên de Fixação das Grandes Áreas Culturais Portuguesas». Estudos de Antropologia, vol. I: 159-181.

—, 1990b (1955), «Algumas Considerações acerca da Estrutura Social do Povo Português». Estudos de Antropologia, vol. I: 183-206.

DIAS, A. Jorge e Margot, 1950, «A Encomendação das Almas». XII Congresso Luso-Espanhol para o Progresso das Ciências. 7a. Secção, Ciências Históricas e Filológicas, T. VIII. Lisboa: 593-664.

—, 1956, "A 'Recomenda das Almas' como Elemento Cultural da Área Luso-Brasileira». Douro-Litoral, 7. ${ }^{a}$ série, III/IV: 1-8.

DIAS, Jaime Lopes, 1926, Etnografia da Beira, vol. I. V. N. Famalicão: Tip. Minerva.

—, 1942, Etnografia da Beira, vol. VI. Lisboa: Torres \& Cia./ Livraria Férin.

-, 1948, Etnografia da Beira, vol. VII. Lisboa; Torres \& Cia./ Livraria Férin.

-, 1953, Etnografia da Beira, vol. VIII. Lisboa: Livraria Férin.

-, 1965, Etnografia da Beira, vol. IX. Lisboa: Livraria Férin. 
DIAS, Maria Alice Borba, 1982, Ilha Terceira. Estudo de Linguagem e de Etnografia. S/indicação do local de edição: Secretaria Regional de Educação e Cultura/ Direcção Regional de Acção Cultural.

DIAS, Ten. Francisco José, 1981, Cantigas do Povo dos Açores. Angra do Heroísmo: Instituto Açoriano de Cultura.

DIAS, Urbano Mendonça, 1946 A Vida de Nossos Avós. Estudo Etnográfico da Vida Açoreana através das suas Leis, Usos e Costumes, vol. V. Vila Franca do Campo: Tip. de "A Crença».

DOUGLASS, William A., 1973, Death in Murelaga. Funerary Ritual in a Spanish Basque Village. Seattle e Londres: University of Washington Press.

DRUMOND, Francisco Ferreira, 1981 (1850), Anais da Ilha Terceira, vol. II. S/indicação do local de edição: Secretaria Regional da Educação e Cultura.

DUMONT, Louis, 1966, Homo Hierarchicus. Essai sur le Système des Castes. Paris: Gallimard.

DUPARC, Pierre, 1958, «Confréries du Saint-Esprit et Communautés d'Habitants au Moyen-Age». Revue Historique de Droit Français et Etranger, 4. ${ }^{\text {eme }}$ série, 36. ${ }^{\text {éme }}$ année, n. ${ }^{\circ}$ 3, 349-367, n. ${ }^{\circ}$ 4: 555-585.

EADE, John e sallnow, Michael, 1991, Contesting the Sacred. The Anthropology of Christian Pilgrimage. Londres: Routledge.

ENES, Maria Fernanda, 1985, A Reforma Tridentina e a Religião Vivida nos Açores (tese dactilografada). Ponta Delgada: Universidade dos Açores.

ENES, P. Inocêncio, 1948, «As Festas do Espírito Santo nos Altares». Boletim do Instituto Histórico da Ilha Terceira, vol. VI: 107-123.

ESPERANÇA, Fr. Manoel da, 1656, História Seráfica dos Frades Menores de S. Francisco na Província de Portugal, I, Lisboa.

EVANS-PRITCHARD, E. E., 1940, The Nuer. A Description of the Modes of Livelihood and Politicai Institutions of a Nilotic People. Oxford: Clarendon Press.

FENTON, Alexander e owen, Trevor, 1981, Food in Perspective. Proceedings of the Third International Conférence on Ethnological Food Research, Cardiff Wales, 1977. Edimburgo: John Donald.

FERNANDES, José Manuel, 1989, Angra do Heroísmo. Lisboa: Presença.

FERNANDES, Manoel, 1690, Alma Instruida na Doutrina e Vida Christã, II, Lisboa.

FERREIRA, Fernando, 1978, Coisas Simples da Terra Tomarense. Festa dos Tabuleiros. Círio da Senhora da Piedade. Algumas Achegas para a sua História. Santarém: Junta Distrital de Santarém.

FERREIRA, P. Ernesto, 1927, A Alma do Povo Micaelense. Ponta Delgada: Oficina de Artes Gráficas.

—, 1959, «As Romarias Quaresmais na Ilha de São Miguel. Sua Origem e Antiguidade». Insulana, vol. XIV: 135-141.

FIGUEIREDO, Jaime de, 1957, Impérios Marienses (Folclore Açoreano). Lisboa: C. de Oliveira.

FONTES, Manuel da Costa, 1980, Romanceiro Português dos Estados Unidos, Vol. I: Nova Inglaterra. Coimbra: Por Ordem da Universidade. 
FOSTER, George, 1965a, «The Dyadic Contract in Tzintzuntzan. II. Patron-Client Relationship. American Anthropologist. vol. 65: 1280-1294.

-, 1965b, «Peasant Society and the Image of Limited Good». American Anthropologist, vol. 67: 293-315.

FRAZER, James G., 1978 (1922), The Golden Bough. A Study in Magic and Religion (Abridged Edition). Londres: Mac Millan Press.

FREEMAN, Susan Tax de, 1970, Neighbours. The Social Contract in a Castillian Hamlet. Chicago: University of Chicago Press.

FRUTUOSO, Gaspar, 1971 (1590), Livro Terceiro das Saudades da Terra. Ponta Delgada: Instituto Cultural de Ponta Delgada.

-, 1977 (1590), Livro Quarto das Saudades da Terra, Volume I. Ponta Delgada: Instituto Cultural de Ponta Delgada.

-, 1978 (1590), Livro Sexto das Saudades da Terra. Ponta Delgada: Instituto Cultural de Ponta Delgada.

-, 1981 (1590), Livro Quarto das Saudades da Terra, Volume II. Ponta Delgada: Instituto Cultural de Ponta Delgada.

FURTADO, Arruda, 1884, Materiaes para o Estudo Antropológico dos Açores. Observações sobre o Povo Micaelense. Ponta Delgada: Tipografia Popular.

GASCON, J. A., 1921/22, «Festas de Monchique. IV. Santo-Espírito». Revista Lusitana, vol. 24: 274-285.

GAYTON, Anna H., 1948, «Descrição das Festas do Espírito Santo feitas pelos Portugueses da Califórnia em 1947». Insulana, vol. IV: 388-402.

-, 1959, «The Festa do Espírito Santo in Three Cultural Settings». Actas do III Colóquio Internacional de Estudos Luso Brasileiros, vol. I. Lisboa: 182.

GEERTZ, Cliford, 1980, Negara. The Theatre State in Nineteenth Century Bali. Princeton, N. J.: Princeton University Press.

GODBOUT, Jacques, 1992, L'Esprit du Don. Paris: Éditions de la Découverte.

Instituto Nacional De Estatística, 1960, X Recenseamento Geral da População no Continente e Ilhas Adjacentes. Lisboa.

-, 1981, XII Recenseamento Geral da População. II Recenseamento da Habitação. Resultados Definitivos. Região Autónoma dos Açores. Lisboa.

ISAMBERT, François-André, 1982, Le Sens du Sacré. Fête et Religion Populaire. Paris: Minuit.

KEIL, Luís, 1917, «O Império do Penedo», A Águia, s. II. vol. XII, 50-52.

LARNOTT, Margaret (ed.), 1981, Gastronomy. The Anthropology of Food and Food Habits. The Hague-Paris: Mouton.

LASLETT, Peter, 1978 (1972), «The History of the Family». Laslett, P. e Wall, R. (eds.), Household and Family in Past Time, Londres: Cambridge University Press: 1-89.

LAURENTIAUX, Daniel-Francis, 1979, Folklore des Açores: Festas em Honra do Divino Espirito Santo (tese dactilografada). Paris: Université de la Sorbonne. 
—, 1983, «Cultes et Confréries du Saint-Esprit aux Açores». Arquivos do Centro Cultural Português, vol. XIX: 79-143.

LEACH, Edmund, 1977 (1961), «Two Essays Concerning the Symbolic Représentation of Time». Rethinking Anthropology, Londres: The Athlone Press, 124-136.

LEAL, João, 1984, Etnografia dos Impérios de Santa Bárbara (Santa Maria, Açores). Lisboa: Instituto Português do Património Cultural/ Departamento de Etnologia.

—, 1989, «As Romarias Quaresmais de São Miguel». Estudos em Homenagem a Ernesto Veiga de Oliveira, Lisboa, Instituto Nacional de Investigação Científica: 409-436.

-, 1991a, «O Ciclo do Carnaval». Pais de Brito, Joaquim (ed.), Portugal Moderno. Tradições, Lisboa, Pomo: 59-63.

—, 1991b, «A Quaresma». Pais de Brito, Joaquim (ed.), Portugal Moderno. Tradições, Lisboa, Pomo: 64-70.

—, 1991c, «Páscoa, Maio e Espírito Santo». Pais de Brito, Joaquim (ed.), Portugal Moderno. Tradições, Lisboa, Pomo: 71-80.

—, 1993a, «As Romarias Quaresmais de São Miguel: Margem e Ciclo Anual num Contexto Português». Gomes da Silva, José Carlos (ed.), Assimetria Social e Inversão. Lisboa, I.I.C.T.: 165-182.

-, 1993b, Festa e Construção da Identidade. O Nível Nacional e Regional: Comunicação apresentada ao Seminário «Problemas da Sociedade Portuguesa», organizado pelo Gabinete de Sociologia Histórica da F.C.S.H. da U.N.L.

LEGOUPIL, Dominique, s/d, Evolution d'une Village des Açores: Lajes das Flores (tese de 3éme. Cycle dactilografada), s/ indicação do local de edição.

LÉVI-STRAUSS, Claude, 1966, Mythologiques. Du Miel aux Cendres. Paris: Pion.

—, 1971 (1947), Les Structures Elémentaires de la Parenté. Paris/ La Haye: Mouton.

LIMA, Gervásio, 1932, Festas do Espírito Santo - Cantores e Cantares. Angra do Heroísmo: Livraria Editora Andrade.

LIMA, Marcelino, 1940, Anais do Município da Horta. Ilha do Faial. Famalicão: Grandes Oficinas Gráficas Minerva.

LOPES, Frederico, 1980a (1957), «As Festas do Espírito Santo». Ilha Terceira. Notas Etnográficas, Angra do Heroísmo, Instituto Histórico da Ilha Terceira: 211-286.

—, 1980b (1950), «Donde Terão Vindo as Varas da Festa do Espírito Santo?» Ilha Terceira. Notas Etnográficas, Angra do Heroísmo, Instituto Histórico da Ilha Terceira: 287-289.

-, 1980c , «Vida Socio-Económica», Ilha Terceira. Notas Etnográficas, Angra do Heroísmo, Instituto Histórico da Ilha Terceira: 421-437.

MACEDO, Silveira de, 1871, História das Quatro Ilhas que Formam o

Distrito da Horta, vol. I. Horta: Typ. Graça Júnior. 
MACHAREL, Claude, 1983, «Don et Réciprocité en Europe». Archives Europeénnes de Sociologie, vol. XXIV: 151-166.

MARQUES, Evaristo, 1950, "Costumes Regionais da Ilha Terceira». Mensário das Casas do Povo, vol. IV, n. ${ }^{\circ} 47:$ 12-13.

MARTINS, Francisco Ernesto Oliveira, 1985, Festas Populares dos Açores, S/ indicação do local de edição: Região Autónoma dos Açores / Imprensa Nacional - Casa da Moeda.

MARTINS, Rui Sousa, 1989, «Os Processos Criativos e as Origens do Povoamento». Oceanos, n. ${ }^{\circ} 1,65-61$.

MAUSS, Marcel, 1983a (1923/24), «Essai sur le Don. Forme et Raison de l'Echange dans les Sociétés Archaiques». Sociologie et Anthropologie, Paris: P.U.F.: 145-279.

—, 1983b (1904/05), «Essai sur les Variations Saisonnières des Sociétés Eskimos. Étude de Morphologie Sociale». Sociologie et Anthropologie, Paris: P.U.F.: 389-477.

MENDES VIEIRA, 1903, «Costumes Açorianos. Festas do Espírito Santo», Álbum Açoriano. 357-362.

MENDONÇA, Elsa B. Lemos de, 1961/62, «Ilha de São Jorge. Subsídios para o Estudo da Etnografia, Linguagem e Folclore Regionais». Boletim do Instituto Histórico da Ilha Terceira, vols. XIX e XX: 5-347.

MESQUITA, Jorge, 1984, Festa e Estratificação Social na Campina (tese dactilografada). Lisboa: Universidade Nova de Lisboa/ Faculdade de Ciências Sociais e Humanas.

MONTE ALVERNE, Fr. Agostinho, 1986 (1695), Crónica da Província de S. João Evangelista das Ilhas dos Açores, vol. I. Ponta Delgada: Instituto Cultural de Ponta Delgada.

MONTEIRO, Armando, 1969, Pedras de Santa Maria (classificação e prefácio de Paulo Caratão Soromenho). Ponta Delgada: Arquipélago.

MONTEIRO, Jacinto, 1982, Memórias da Minha Ilha. Santa Maria: ed. do autor.

-, 1983, A Invocação do Espírito Santo nas Crises Sísmicas dos Açores (manuscrito inédito).

MOURA, José D. G. Motta e, 1977 (1855), Memória Histórica da Notável Vila de Niza. Lisboa: Imprensa Nacional - Casa da Moeda.

NASH, Manning, 1958, «Politicai Relations in Guatemala». Social and Economie Studies, vol. 7: 65-75.

NEMÉSIO, Vitorino, 1986a (1928), «O Açoriano e os Açores», Gouveia, M. Margarida (ed.), Vitorino Nemésio. Estudo e Antologia. Lisboa, Instituto de Cultura e Língua Portuguesa: 317-329.

-, 1986 b (1932), «Açorianidade». Gouveia, M. Margarida (ed.), Vitorino Nemésio. Estudo e Antologia. Lisboa, Instituto de Cultura e Língua Portuguesa: 401-402.

NEVES, Eduíno, 1959, A Ilha de Santa Maria. Contributo para um Estudo de Geografia (tese dactilografada). Coimbra: Universidade de Coimbra. 
NOGUEIRA, J. V. Paula, 1894, As Ilhas de São Miguel e Terceira. Lisboa: Portugal Agrícola.

«O Culto do Divino Espírito Santo nos Açores», 1959. Boletim Eclesiástico dos Açores, T. XXXV: 431-442.

O'NEILL, Brian, 1984, Proprietários, Lavradores e Jornaleiras. Desigualdade Social numa Aldeia Transmontana (1870-1978). Lisboa: Publicações Dom Quixote.

—, 1989, «Repensando Trabalhos Colectivos Lúdicos. A Matança do Porco em Alto Trás-os-Montes». Estudos em Homenagem a Ernesto Veiga de Oliveira. Lisboa, Instituto Nacional de Investigação Científica: 471-520.

ORMONDE, Maria Helena, 1985/\&6, Uma Freguesia Rural em Mudança (tese dactilografada). Lisboa; Universidade Nova de Lisboa/Faculdade de Ciências Sócias e Humanas.

OTT, Sandra, 1980, «Blessed Bread, «First Neighbours» and Asymetric Exchange in the Basque Country». Archives Européennes de Sociologie, vol. XXI: $40-58$.

-, 1981, The Circle of Mountains. A Basque Shepherding Community. Oxford: Clarendon Press.

PACHECO, Norberto Cunha, 1986, Graciosa, as Tradições e as Paisagens de uma Ilha. Graciosa: S.R.T.T./ S.R.E.C./ Câmara Municipal de Santa Cruz da Graciosa.

PARRY, Jonathan, 1986, "The Gift, the Indian Gift and the 'Indian Gift'», Man: 21 (3), 453-473.

PARRY, Jonathan e BLOCH, Maurice (eds.), 1989, Money and the Morality of Exchange. Cambridge: Cambridge University Press.

PASTORAL, 1876, Boletim do Governo Eclesiástico dos Açores, T. II: 292-336.

PASTORAL AOS FIÉIS DA FREGUESIA DE N. S. DOS REMÉDIOS DA FAJANZINHA nesta Ilha das Flores, 1876, Boletim do Governo Eclesiástico dos Açores, T. II: 289-292.

PAVÃO Jr., José de Almeida, 1981, Aspectos do Cancioneiro Popular Açoriano. Ponta Delgada: Universidade dos Açores.

PEREIRA, Benjamim, 1973, Máscaras Portuguesas. Lisboa: Junta de Investigações do Ultramar/ Museu de Etnologia do Ultramar.

PEREIRA, Con. J. A., 1950, Sobre as Festas do Espírito Santo - Censuras e Leis da Autoridade Diocesana desde 1560». Boletim do Instituto Histórico da Ilha Terceira, vol. VIII: 58-63.

PEREIRA, Eduardo C. N., 1986 (1939), Ilhas de Zarco. Funchal: Câmara Municipal do Funchal.

PINA-CABRAL, João, 1986, Sons of Adam. Daughtors of Eve. The Peasant World View of the Alto Minho. Oxford: Clarendon Press.

-, 1991, «Casamento, Compadrio e Vizinhança», Os Contextos da Antropologia. Lisboa, Difel, 213-239.

PIRES, A. Tomás, 1908, «Investigações Etnográficas». Revista Lusitana, vol. 11: 63-78. 
PITT-RIVERS, Julian, 1971 (1954), The People of the Sierra (2. ${ }^{\text {a }}$ edição). Chicago: The University of Chicago Press.

-, 1977 (1963), "The Law of Hospitality», The Fate of Seehem or the Politics of Sex. Essays in the Anthropology of the Mediterranean, Cambridge, Cambridge University Press: 94-112.

PRATT, Alfredo de, 1899, «O Imperador de Eiras». A Tradição, vol. I: 152-155 .

PROPP, Vladimir, 1978 (1963), Feste BIBLIOGRAFIA Una Ricerca Storico-Etnografica (trad, de Rita Bruzzese). cm.. 亡m..... Dedalo.

PROVISÃO, 1925, Boletim Eclesiástico dos Açores, T. XXVII: 40-43.

QUADROS, António, 1987, Portugal, Razão e Mistério. Livro 2. O Projecto Áureo ou o Império do Espírito Santo. Lisboa: Guimarães Editores.

RAMAlHO, Paulo, s/d, S. Antão. Entre o Passado e o Presente, Entre o que Foi e o que E (tese dactilografada). Lisboa: Universidade Nova de Lisboa/Faculdade de Ciências Sociais e Humanas.

REGULAMENTO DOS ROMEIROS DA ILHA DE SÃO MIGUEL, 1962, Boletim do Governo Eclesiástico dos Açores, vol. 37: 38-46.

RESOLUÇÕES APROVADAS NAS CONFERÊNCIAS DO CLERO CELEBRADAS EM ANGRA DO HEROÍSMO sob a Presidência de Sua Exa. Revma. nos Dias 24 e 25 de Setembro de 1894, 1895, Boletim do Governo Eclesiático dos Açores, T. XII: 129-136.

REY. Pe, Alberto Pereira, 1881, «Breve Notícia das Festas do Imperador e Vodo». Arquivo dos Açores, vol. Ill: 285-300.

RIBEIRO, José Diogo, 1908, Memórias de Turquel. Porto: Tipografia Universal. RIBEIRO, Luís Silva, 1982 (1942), «Os Foliões do Espírito Santo nos Açores». Obras, vol. I, Angra do Heroísmo, Instituto Histórico da Ilha Terceira/ Secretaria Regional da Educação e Cultura: 253-266.

—, 1983 (1864), «Subsídios para um Ensaio sobre a Açorianidade (Seguidos de «A Pretendida Influência Nórdica no Povo Micaelense)». Obras, vol. II, Angra do Heroísmo, Instituto Histórico da Ilha terceira/Secretaria Regional da Educação e Cultura: 515-564.

RIBEIRO, Orlando, 1955, Aspectos e Problemas da Expansão Portuguesa. Lisboa: Fundação da Casa de Bragança.

—, 1963 (1945), Portugal. O Mediterrâneo e o Atlântico. Lisboa: Sá da Costa.

REIGELHAUPT, Joyce F., 1973, «Festas and Padres. The Organization of Religious Action in a Portuguese Parish». American Anthropologist, vol. 75: 835-852.

ROCHA-TRINDADE, Maria Beatriz, 1976, «Comunidades Migrantes em Situação Dipolar». Análise Social, XII: 983-987.

SAHLINS, Marshall, 1963, «Poor Man, Rich Man, Big-Man, Chief: Political Types in Melanesia and Polynesia». Society and History, vol. V: 285-333 .

-, 1978 (1965), «On the Sociology of Primitive Exchange». Stone Age Economics, London, Tavistock Publications: 185-275. 
SALVADOR, Mari Lynn, 1981, Festas Açoreanas. Portuguese Religions Célébrations in Califórnia and the Azores, Oakland: The Oakland Muséum History Department.

-, 1985, «Symbolism and Ephemeral Art. An Analysis of the Aesthetic Aspects of the Festas do Divino Espírito Santo», Boletim do Instituto Histórico da Ilha Terceira, vol. XLIII: 243-289.

SANCHIS, Pierre, 1983, Arraial, Festa de um Povo. As Romarias Portuguesas. Lisboa. Publicações Dom Quixote.

SARAIVA, Álvaro e Teixeira, Dias, 1987, Romeiros, Peregrinos de Hoje. Ponta Delgada: edição dos autores.

SARMENTO, Artur Alberto, 1951, Fasquias e Ripas da Madeira. Funchal: Junta Geral do Distrito Autónomo do Funchal.

SERVIÇO REGIONAL DE ESTATÍSTICAS DOS AÇORES, 1985, Recenseamento Agrícola/85 dos Açores, Mapas respeitantes às freguesias de Nossa Senhora da Piedade (Pico), Santa Bárbara (Santa Maria) e Santo Antão (São Jorge), Angra do Heroísmo.

SILVA, Agostinho da, 1985, «Dez Notas sobre o Culto Popular do Espírito Santo». Boletim do Instituto Histórico da Ilha Terceira, vol. xlii: 173-180 .

SILVA, P. Fernando A. e meneses, Carlos Azevedo, 1984 (1921), Elucidário Madeirense. Funchal: Secretaria Regional do Turismo e Cultura/Direcção Regional de Acção Cultural.

SIMÕES, Manuel Breda, 1985, «Le Symbolisme du Triple Couronnement et les «Empires» du Saint-Esprit. Boletim do Instituto Histórico da Ilha Terceira, vol. xlii: 173-180.

- 1986, «O Espírito da Santa Cruzada e a Cruzada do Espírito Santo». Gabinete de Estudos de Simbologia (ed.), Cavalaria Espiritual e Conquista do Mundo. Lisboa, Instituto Nacional de Investigação Científica: 165-175.

-, 1987, Roteiro Lexical do Culto e Festas do Espírito Santo nos Açores. Lisboa: Instituto de Cultura e Língua Portuguesa.

SMITH, Pierre, 1979, «Aspects de l'Organisation des Rites». Izard, M. e Smith, P. (eds.), La Fonction Symbolique. Essais d Anthropologie, Paris, Gallimard: 139-170.

—, 1981, «La Festa nel suo Contesto Rituale». Bianco, C. e Del Ninno, M.(eds.), Festa. Antropologia e Semiótica, Florença, Nuova Guaraldi Editrice: 212-219.

SMITH, Waldemar, 1981 (1977), El Sistema de Fiestas y el Cambio Economico (trad. de Gerardo Novas). Mexico: Fondo de Cultura Economica.

SOARES, Micaela, 1982, Os Impérios Populares. Lisboa: separata do Boletim Cultural da Assembleia Distrital de Lisboa.

SOUSA, Tude Martins de e rasquilho, Francisco v., 1936, Amieira do Antigo Priorado do Crato (Subdidios para uma Monografia). Figueira da Foz: Tipografia Popular.

SPIRITUALITÉ PASCALE, 1957, Paris: Desclée de Brower. 
TAK, Herman, 1990, «Longing for Local Identity: Intervillage Relations in an Italian Mountain Area». Anthropological Quarterly, 63 (2): 90-100.

TAVARES, P. José João, 1979 (1944), A Vila da Lagoa e o seu Concelho (Subsídios para a sua História). Ponta Delgada: Câmara Municipal da Lagoa.

TEIXEIRA, Vasco, 1991, «Manjares Cerimoniais», Pais de Brito, Joaquim (ed.) Portugal Moderno. Tradições. Lisboa, Pomo: 189-197.

TURNER, Victor, 1969a, «Liminality anBIBLIOGRAFIA . The Ritual Process. Structure and Anti-Structure, Chicago, tawn a wusuling Company: 94-130 .

—, 1969b, «Communitas: Mode and Process». The Ritual Process. Structure and Anti-Structure, Chicago, Aldine Publishing Company: 131-165.

-, 1974, «Metaphors of Anti-Structure in Religious Culture». Dramas, Fields and Metaphors. Symbolic Action in Human Society, Ithaca, Cornell University Press: 272-299.

VAN GENNEP, Arnold, 1909, Les Rites de Passage. Paris: Picard.

-, 1947, Manuel de Folklore Français Contemporain, Tomo Primeiro, Vol. 3, Cérémonies Périodiques, Cycliques et Saisonnières. 1. Carnaval/Carême - Pâques. Paris: Picard.

-, 1949, Manuel de Folklore Français Contemporain, Tomo Primeiro, Vol. 4, Cérémonies Périodiques, Cycliques et Saisonnières. 2. Cycle de Mai La Saint Jean. Paris: Picard.

VARGAS, Olímpia e machado, Rosa Maria, s/d, Sismos Ocorridos nas Ilhas dos Açores de 1444 a 1900. Contributo para a sua História (texto dactilogrado inédito).

VASCONCELOS, José Leite de, 1925, A Barba em Portugal. Estudo de Etnografia Comparada. Lisboa: Imprensa Nacional.

-, 1926, Mês de Sonho. Conspecto de Etnografia Açórica. Lisboa: Livraria Universal de Armando J. Tavares.

—, 1958, Etnografia Portuguesa. Tentame de Sistematização, Vol. IV (elaborado segundo os materiais do autor ampliados com nova informação por M. Viegas Guerreiro). Lisboa: Imprensa Nacional - Casa da Moeda.

-, 1982, Etnografia Portuguesa. Tentame de Sistematização, Vol. VIII (organização de M. Viegas Guerreiro, com a colaboração de A. Soromenho e P. Soromenho). Lisboa: Imprensa nacional - Casa da Moeda.

VEIGA DE OLIVEIRA, Ernesto, 1966, Instrumentos Musicais Populares Portugueses. Lisboa: Fundação Calouste Gulbenkian.

—, 1984a (1956), «Subsídios para o Estudo do Entrudo em Portugal - o «Enterro do João». Festividades Cíclicas em Portugal. Lisboa, Publicações Dom Quixote: 17-46.

—, 1984b (1952), «O Entrudo». Festividades Cíclicas em Portugal. Lisboa, Publicações Dom Quixote: 47-50.

—, 1984c (1960), «Os «Compadres» e as «Comadres» do Carnaval». Festividades Cíclicas em Portugal. Lisboa, Publicações Dom Quixote: 51-58. 
AS FESTAS DO ESPÍRITO SANTO NOS AÇORES

—, 1984d (1956), «Manjares Cerimoniais do Entrudo em Portugal», Festividades Cíclicas em Portugal. Lisboa: Publicações Dom Quixote: 59-68 .

—, 1984e (1957), «Folares e Ovos de Páscoa em Portugal», Festividades Cíclicas em Portugal. Lisboa. Publicações Dom Quixote: 85-96.

—, 1984f (1958), «O Primeiro de Maio», Festividades Cíclicas em Portugal. Lisboa. Publicações Dom Quixote: 97-107.

—, 1984g, «As Maias», Festividades Cíclicas em Portugal. Lisboa, Publicações Dom Quixote: 109-111.

—, 1984h (1955/57), «A Quinta-Feira de Ascensão em Portugal». Festividades Cíclicas em Portugal. Lisboa, Publicações Dom Quixote: 113-118.

—, 1984i (1960), «Manjares e Refeições Cerimoniais». Festividades Cíclicas em Portugal. Lisboa, Publicações Dom Quixote: 203-206.

-, 1986, Instrumentos Musicais Populares dos Açores. Lisboa: Fundação Calouste Gulbenkian.

VEIGA DE OLIVEIRA, Ernesto e PEREIRA, Benjamim, 1987. Tecnologia Tradicional dos Açores. Subsídios para o seu Estudo. Lisboa: Instituto Nacional de Investigação Científica.

VERÍSSIMO, Nelson, 1985, «a Festa do Espírito Santo». Atlântico, n. ${ }^{\circ}$ 1: 9-17.

-, 1988, A Festa do Espírito Santo na Madeira. Comunicação apresentada à 2. ' Semana de Etnologia do Atlântico, Angra do Heroísmo, 15 a 21 de Agosto de 1988.

VOVELLE, Michel, 1982, Idéologies et Mentalités. Paris: Maspero.

WOLF, Eric, 1955, «Types of Latin American Peasantry: a Preliminary Discussion». American Anthropologist, vol. 47: 452-471.

—, 1966, Peasants. Englewood Cliffs, N.J.: Prentice-Hall.

ZONABEND, Françoise, 1980, La Mémoire Longue. Temps et Histoire au Village. Paris: P.U.F.

—, 1981, «Le Très Proche et le Pas Trop Loin. Réflexions sur l'Organisation du Champ Matrimonial des Sociétés de Parenté Complexes». Ethnologie Française, vol. XI: 311-318. 


\section{ÍNDICE DE QUADROS}

Quadro 1 - População dos Açores por Ilha (1981) .................... 26

Quadro 2 - Distribuição da população por lugares em Santa Bárbara

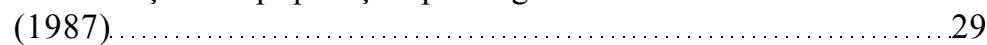

Quadro 3 - Composição das Unidades Domésticas em Santa Bárbara (1987) ...................................................... 31

Quadro 4 - Emigração em Santa Bárbara (1962-1987) . ............. 32

Quadro 5 - Classes etárias na população de Santa Bárbara (1987).. 33

Quadro 6 - Impérios promovidos por emigrantes e Impérios Promovidos por locais em Santa Bárbara (1964-1987). . . . . 41

Quadro 7 - Impérios do tempo e fora do tempo em Santa Bárbara

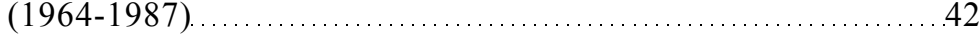

Quadro 8 - Gado abatido para os Impérios em Santa Bárbara (1965-1987) .................................................. 48/49

Quadro 9 - Composição das Irmandades (Impérios de 1987) . . . . . . 50

Quadro 10 - Cabeças de gado abatidas e cabeças de gado oferecidas (Impérios de 1987) ....................................52

Quadro 11 - Esmolas e Jantares em Santa Bárbara (1964-1987) . . . . 61

Quadro 12 - Ajudantes e Parentes nos Impérios (Santa Bárbara,

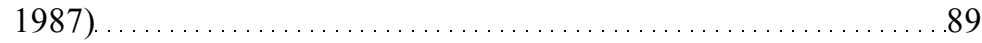

Quadro 13 - Ajudantes e Parentes nos Impérios (Santa Bárbara,

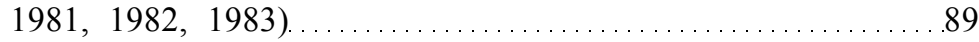

Quadro 14 - Ajudantes e Vizinhos de Perto nos Impérios de Santa

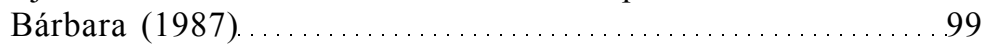

Quadro 15 - Irmandades e Parentes nos Impérios de Santa Bárbara

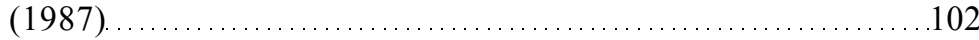

Quadro 16 - Cabeças de gado oferecidas por parentes nos Impérios

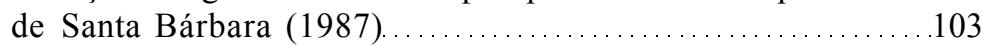

Quadro 17 - Irmandades e Reconhecimentos nos Impérios de Santa

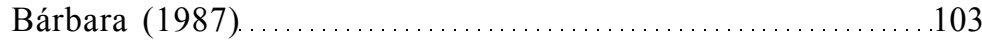


Quadro 18 - Exogamia de lugar em Santa Bárbara (1917-1982) . . . . . 109

Quadro 19 - Participação das casas da freguesia na Irmandade dos

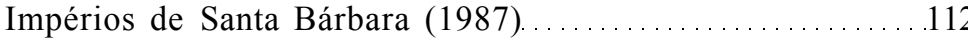

Quadro 20 - Organização do calendário agrícola anual em Santa

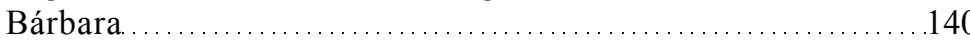

Quadro 21 - Despesa dos Imperadores relativamente ao custo total dos Impérios de Santa Bárbara (1987)...................... 154

Quadro 22 - Designações dos Festejos no Grupo Central ............... 176

Quadro 23 - Distribuição da população por lugares em Santo Antão

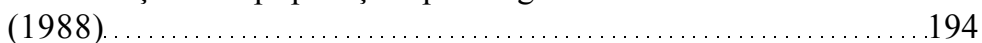

Quadro 24 - Membros das Irmandades do Espírito Santo em Santo

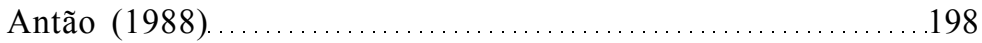

Quadro 25 - Amassadeiras e parentes nos Jantares e Gastos em Santo

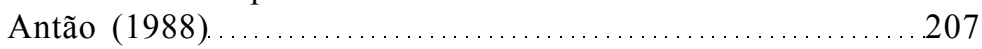

Quadro 26 - Parentes e ofertas nos Jantares e Gastos em Santo Antão

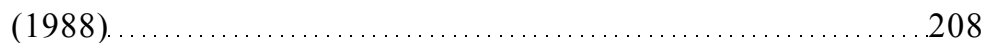

Quadro 27 - Jantares e lugares em Santo Antão (1988). . . . . . . . . . . . 210

Quadro 28 - Distribuição da população por lugares (Piedade, 1989). 224

Quadro 29 - Pontos e ofertas nos Impérios (Piedade, 1989) . . . . . . . . 228

Quadro 30 - Coroações, visitas e pontos (Piedade, 1989) . . . . . . . . . 229 


\section{ÍNDICE DE MAPAS}

Mapa 1 A freguesia de Santa Bárbara (Santa Maria). . . . . . . . . . . 27

Mapa 2 Lugares do Forno e da Cruz de São Mor (Santa Bárbara) 62

Mapa 3 Ajudantes e vizinhos de perto (Segundo Império de Santa

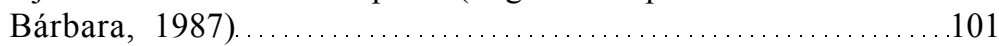

Mapa 4 Ajudantes e vizinhos de perto (Primeiro Império do

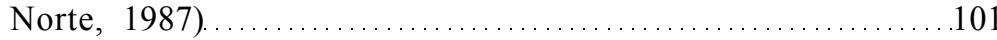

Mapa 5 Ajudantes e vizinhos de perto (Segundo Império do Norte,

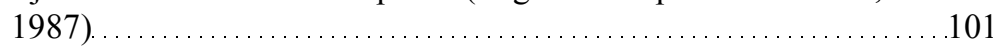

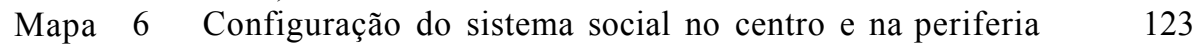

Mapa 7 Lugares periféricos: Lagoinhas vs. Forno. .................. 125

$\begin{array}{llll}\text { Mapa } & 8 & \text { Principais Variantes das Festas do Espírito Santo nos Açores. } & 168\end{array}$

Mapa 9 Festas do Espírito Santo na Terceira: fontes da recolha 171

Mapa 10 Festas do Espírito Santo em São Jorge: fontes da recolha 177

Mapa 11 Festas do Espírito Santo no Pico: fontes da recolha. . . . 177

Mapa 12 Festas do Espírito Santo na Graciosa: fontes da recolha 178

Mapa 13 Festas do Espírito Santo no Faial: fontes da recolha.... 181

Mapa 14 Festas do Espírito Santo em São Miguel: fontes da recolha ......................................................182/183

Mapa 15 Festas do Espírito Santo nas Flores e Corvo: fontes da

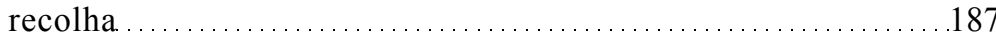

Mapa 16 A freguesia de Santo Antão (São Jorge) ....................196/197

Mapa 17 A freguesia da Piedade (Pico) ............................ 225

Mapa 18 Pontos e lugares nas Festas do Espírito Santo na Piedade 232

Mapa 19 Itinerário do rancho de Ponta Garça (1988) ............. 244/245

Mapa 20 Distribuição das Festas do Espírito Santo no Continente 289 


\section{ÍNDICE DE FIGURAS}

Figura 1 - Organização dos cortejos do Império ................. 47

Figura 2 - Organização do cortejo que leva o Império para a Copeira 56

Figura 3 - 0 mecanismo da promessa nos Impérios ..............69 69

Figura 4 - Integração recíproca dos lugares .......................... 110

Figura 5 - Carnaval, Quaresma e Impérios............................134

Figura 6 - Estrutura do ciclo cerimonial anual em Santa Bárbara... 141

Figura 7 - Estrutura das Festas do Espírito Santo na Terceira ....... 172

Figura 8 - Organização dos cortejos que antecedem e se seguem à Coroação (Santo Antão) ..................................... 199

Figura 9 - Organização do cortejo que rodeia a Coroação (Piedade) 226

Figura 10 - Organização dos ranchos de romeiros ..................... 243 


\section{ÍNDICE DE DIAGRAMAS}

Diagrama 1 - Ajudantes e parentes (Primeiro Império de Santa Bárbara, 1987) $90-91$

Diagrama 2 - Ajudantes e parentes (Segundo Império de Santa Bárbara (1987)

Diagrama 3 - Ajudantes e parentes (Primeiro Império do Norte, 1987) ....................................................94-95

Diagrama 4 - Ajudantes e parentes (Segundo Império do Norte, 1987).

$.96-97$ 


\section{PoRJuGALdePERTO}

\section{'BibliotecadeEtnografia êAntropologia}

\section{$A_{s \text { Festas do Espírito Santo nos }}$}

Açores. Um Estudo de Antropologia Social procura interrogar um dos mais complexos e sedutores rituais que integram o calendário cerimonial em Portugal.

Desenvolvendo-se a partir da observação intensiva dos Impérios numa freguesia da ilha de Santa Maria, o estudo percorre depois, numa perspectiva comparativa, outras ilhas açorianas.

Com base no relevo que tem nas Festas do Espírito Santo um conjunto muito diversificado de dádivas e contra-dádivas de alimentos cerimoniais, 0 autor propõe uma interpretação do ritual assente na consideração simultânea da sua dimensão religiosa, da sua relação com os principais círculos de relácionamento social e do vínculo que ele exibe com as formas de conceptualização do tempo nas comunidades estudadas. Aspectos controversos como a procura de prestígio individual através das despesas requeridas pelos festejos ou as relações entre povo e clero em torno do ritual são também examinados.

Pela natureza dos problemas discutidos, AS Festas do Espirito Santo nos Açores constitui não apenas uma contribuição para uma Antropologia Social do arquipélago, mas uma oportunidade para o reexame de alguns dossiers mais genéricos relacionados com o estudo antropológico das comunidades rurais em domínio europeu. 